\title{
Mikroökonómiai feladatok tára II.
}

Megoldás = Megértés

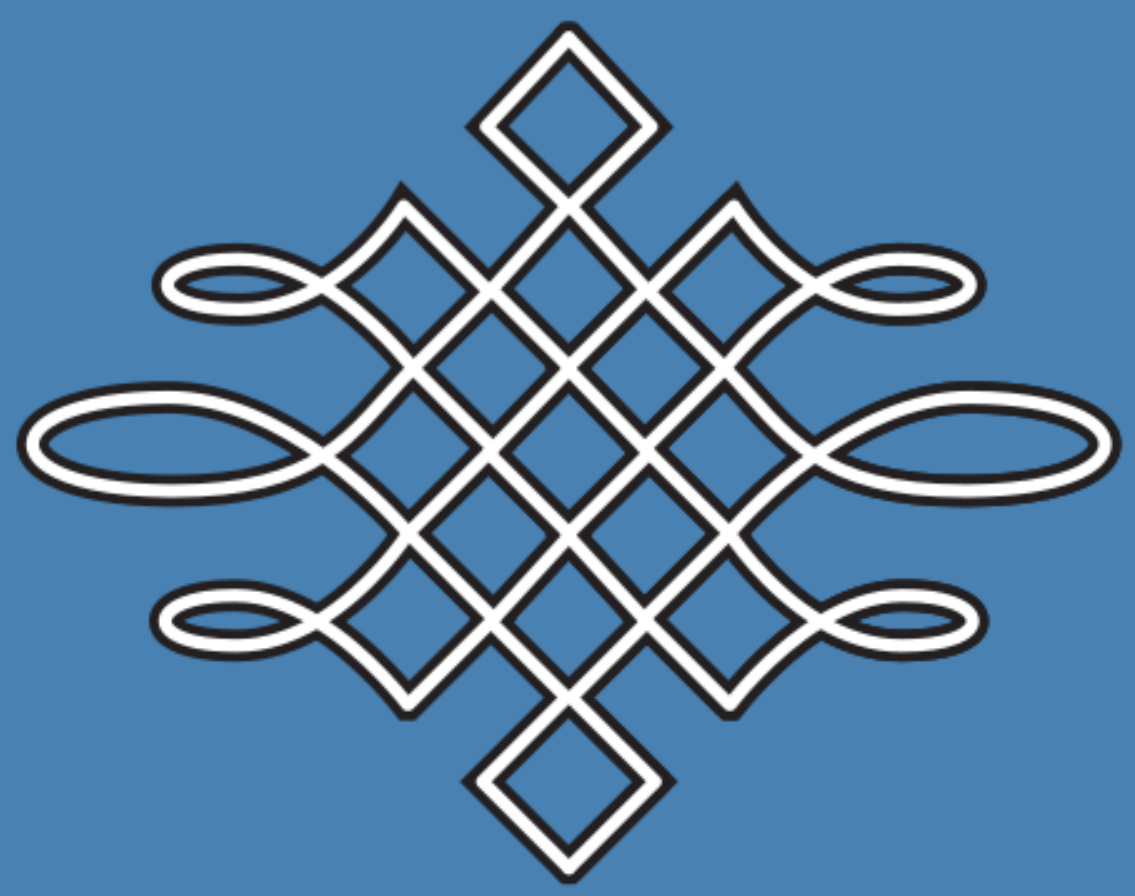

Szerző: CSEKŐ IMRE-PÁLVÖLGYI DÉNES

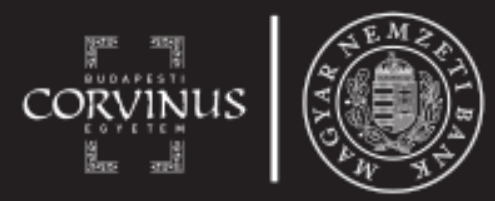


Mikroökonómiai feladatok tára II.

Budapest I 2019. 


\section{Csekő Imre-Pálvölgyi Dénes}

\section{Mikroökonómiai feladatok tára II.}


Budapesti Corvinus Egyetem

Közgazdaságtudományi Kar

Matematikai Közgazdaságtan és Gazdaságelemzés Tanszék

\section{Cím:}

Mikroökonómiai feladatok tára II.

Szerzó:

(C) Csekő Imre-Pálvölgyi Dénes

A szöveget gondozta:

Szilágyi Ágnes

\section{Kiadó:}

Budapesti Corvinus Egyetem I 1093, Budapest, Fővám tér 8.

\section{Nyomdai kivitelezés:}

Komáromi Nyomda

ISBN 978-963-503-753-7 (e-book)

DOI $10.14267 / \mathrm{cb} .2018 \mathrm{k} 06$

Budapest I 2019.

„A Budapesti Corvinus Egyetem és a Magyar Nemzeti Bank együttmúködési megállapodása keretében támogatott mú."
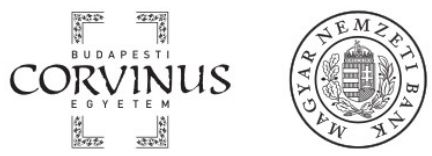


\section{TARTALOM}

I. Feladatok 9

$\begin{array}{lr}\text { Intertemporális választások } & 11\end{array}$

$\begin{array}{lr}\text { Az aktívák piacai } & 16\end{array}$

$\begin{array}{lr}\text { A bizonytalanság } & \mathbf{2 0}\end{array}$

$\begin{array}{lr}\text { Technológia } & 27\end{array}$

$\begin{array}{lr}\text { Profitmaximalizálás } & \mathbf{3 0}\end{array}$

Költségminimalizálás $\quad 33$

$\begin{array}{lr}\text { Költséggörbék } & 37\end{array}$

Vállalati kínálat $\quad 41$

$\begin{array}{lr}\text { Iparági kínálat } & 45\end{array}$

$\begin{array}{lr}\text { Termelés } & \mathbf{5 1}\end{array}$

$\begin{array}{lr}\text { A monopólium } & 56\end{array}$

$\begin{array}{lr}\text { Monopolista viselkedés } & \mathbf{5 9}\end{array}$

$\begin{array}{lr}\text { Tényezópiacok } & 64\end{array}$

$\begin{array}{lr}\text { Oligopólium } & 68\end{array}$

$\begin{array}{lr}\text { Külsố gazdasági hatások } & 74\end{array}$

$\begin{array}{lr}\text { Közjavak } & 79\end{array}$ 
Költséggörbék 
Iparági kínálat

Termelés 248

A monopólium 269

Monopolista viselkedés 279

Tényezópiacok 295

Oligopólium 306

Külsố gazdasági hatások 328

Közjavak 


\section{Előszó}

Ez a példatár, amely az elmúlt években a Mikroökonómia II. címú tárgy oktatása során használt feladatainkból ad válogatást, folytatása a nemrégiben megjelent Mikroökonómiai feladatok tára I. címú feladatgyújteménynek, amit az Olvasó fellelhet a http://unipub.lib.uni-corvinus.hu/3652/1/2018k03.pdf címen. Szinte mindent érdemes lenne idemásolni, amit az előző kötet előszavában is írtunk, de - miután bárki könnyen megnézheti azt - csak egy gondolatot emelnénk ki és nyomatékosítanánk:

„Példatárunk két szempontból is különbözik az általában közreadott feladatgyújteményektől. ... kifejezetten törekedtünk arra, hogy lehetőleg csak olyan feladatokat tartalmazzon, amelyekhez nem elég a tananyag képleteinek ismerete, hanem kicsit komolyabban »el kell gondolkozni rajtuk«. Úgy véljük ugyanis, hogy a tananyag megértéséhez nem elegendő annak egyszerú ismerete, hanem azt alkalmazni is tudni kell. Feladataink ilyen »alkalmazások«. Éppen ezért csak az a diák használhatja komoly eredménnyel ezt a kötetet, aki előbb visszaolvassa és megérti az órákon írt jegyzeteit és a tankönyvet. ... (A példatár) szerkezet(e) lehetővé teszi, hogy a hallgató önállóan megoldhassa a feladatot, ellenőrizhesse annak eredményét. Ha esetleg saját megoldása nem egyezne meg az itt közölttel, akkor érdemes újra próbálkoznia. Ha pedig »bedobja a törülközőt «, akkor a megoldás menetét is megtekintheti azért, hogy ebből rájöjjön, hol is hibázott. Nagyon reméljük, hogy minél kevesebb alkalommal kell átugrania a harmadik részhez, de ha mégis, akkor hasznára válik, és megérti a példában meghúzódó gondolatot."

Hangsúlyozzuk, hogy a feladatgyújtemény alcíme: „Megoldás = Megértés” nem arra utal, hogy aki elolvassa a Megoldások részt, az meg is érti a tananyagot, hanem arra, hogy az elsajátítandó ismeretek tényleges megértését a feladatok megoldása segíti. A tanulás folyamatában semmi nem helyettesítheti az önálló próbálkozást. A példákat megoldani csak az tudja, aki ténylegesen érti az anyagot, és a példamegoldással való esetlegesen sikertelen kisérletezgetés pont az jelzi, hogy még nem jutottunk el a megértés szükséges fokára.

Az első kötethez hasonlóan az Olvasó itt is találkozhat néhány feladatnál a $(G A)$ jelzéssel. Ez néhai kedves kollégánkra, illetve mentorunkra és barátunkra, Gömöri Andrásra utal, a példa eredetileg tőle származik, a megoldásokat mi illesztettük ide. Andrással hosszú éveken keresztül közösen oktattuk e tárgyakat, gondolkodásmódja, tudása 
és egyénisége letagadhatatlan hatással volt munkánkra. A példatár második kötetét is az ő emlékének ajánljuk.

Ahogy azt az előző kötetben is jeleztük: ,igazán reméljük, hogy ha már hallgatóinknak ennyit kellett várniuk egy olyan feladatgyújteményre, amelyet tanáraik kifejezetten e kurzusokhoz terveztek, akkor az a következó években sokat segít majd nekik a tanagyag minél mélyebb elsajátításában, a mikroökonómia megértésében, és ami számukra - rövid távon - talán még fontosabb, a vizsgákra való sikeres felkészülésben."

Budapest, 2018. december

Csekő Imre, Pálvölgyi Dénes 
I. rész

Feladatok 
INTERTEMPORÁLIS VÁLASZTÁSOK 
1. feladat: János és Pál (esetleg John and Paul) egy zenekarban játszanak. Menedzserükkel idei és a következő évi jövedelmükről szerződést kötöttek, János jövedelemáramlása $(242,110)$, Pálé $(200,110)$. A kamatláb 21\%-os. Mekkora a kettejükre vonatkoztatott rawlsi jóléti függvény értéke (azaz, kettejük elérhető hasznossága közül a kisebb), ha mindkettejük intertemporális hasznossági függvénye ugyanaz: szimmetrikus Cobb-Douglas-típusú és a kitevők összege kettő? (Az eredmény 100-zal osztható egész szám, amennyiben a számítás közben kerekített, lehet, hogy az Ön végeredménye nem lesz az.)

Eredmény Megoldás

2. feladat: Anna minden elfogyasztott két gombóc fagylalthoz egy gombóc tejszínhabot vesz. Természetesen nem ragaszkodik ahhoz, hogy minden héten ugyanannyi fagylaltot egyen. Hasznossági függvénye

$$
U=\min \left\{f_{1}, 2 h_{1}\right\} \min \left\{f_{2}, 2 h_{2}\right\},
$$

ahol $f_{1}$ az elsô héten, $f_{2}$ a második héten elfogyasztott fagylalt-, míg $h_{1}$, illetve $h_{2}$ a megfelelő időben fogyasztott tejszínhabgombócok száma. A fagylalt ára 2 garas, a tejszínhabé 1 garas gombóconként. Kétheti jövedelmének jelenértéke 100 garas, a heti kamatláb 1\%. Hány gombóc fagylaltot fogyaszt Anna ezen a héten?

Eredmény Megoldás

3. feladat: Cilike hasznossági függvénye $U\left(x_{0}, x_{1}\right)=\ln a\left(\operatorname{aln} x_{0}+4 \ln x_{1}\right)$ alakú, ahol $x_{0}$ az idei, $x_{1}$ a jövő évi fogyasztása. Mekkora az $a$ paraméter értéke, ha tudjuk, hogy 50\%-os kamatláb mellett Cilike ma pontosan kétszer annyit fogyaszt, mint jövőre?

\section{Eredmény Megoldás}

4. feladat: Hugó húga, Hugi, idén 400 tallért keres. (Egy tallér = 50 garas, de ez érdektelen.) Jövőre automatikusan emelkedik a fizetése 480 tallérra. Hasznossági függvénye

$$
U\left(x_{0}, x_{1}\right)=0,6 \ln x_{0}+0,4 \ln x_{1}
$$

alakú, a kamatláb 20\%-os. (Ekkora kamat mellett adhat-vehet kölcsön.)

a. Hány tallér értékű fogyasztási cikket vásárol az idén?

b. Ha rögtön ez év elején nyer 400 tallért a lottón, miként változik az idei fogyasztása?

Eredmény Megoldás 
5. feladat: Csabi Dani intertemporális hasznosságfüggvénye szimmetrikus CobbDouglas-alakú. Az idén 600 garast keres, de 620 (egységnyi árú) fogyasztási cikket vásárol. A kamatláb 10 \%-os.

a. Mennyi pénzt keresett volna a második évben, ha nem nyer?

Dani nem csak okos, hanem szerencsés is, mert egy év múlva némi pénzhez jutott a ruletten, így pontosan ötször annyi fogyasztási cikket vehet, mint amennyire a nyeremény nélkül számított.

b. Mennyi pénzt nyert a ruletten?

c. Ha biztos lett volna a nyereményben, mennyit költött volna idén?

Eredmény Megoldás

6. feladat: Abraxas két időszakon keresztül csak gitárzenét és dobpergést fogyaszt. Sajnos, mind a kettóért fizetnie kell, de szerencsére az egységárak nem változnak, nincs infláció. A gitárzene ára $p_{g}=1$, a dobpergésé $p_{d}=3$. Abraxas jövedelme idén 100 egység, jövőre 110, a kamatláb 10\%-os. Hasznossági függvénye kicsit komplikált:

$$
U\left(g_{1}, d_{1}, g_{2}, d_{2}\right)=\left(\min \left\{g_{1}, d_{1}\right\}\right)\left(g_{2}+d_{2}\right),
$$

ahol $g$ a gitárzene, $d$ a dobpergés mennyisége. Hány egységgel nő Abraxas gitárzenefogyasztása az első időszakról a másodikra?

\section{Eredmény Megoldás}

7. feladat: Kronosz idén $\left(c_{1}\right)$ és jövőre $\left(c_{2}\right)$ fogyasztásra költött pénzre vonatkozó hasznosságfüggvénye

$$
U\left(c_{1}, c_{2}\right)=\ln \left(c_{1}\right)+\ln \left(c_{2}\right) .
$$

A piaci kamatláb 20\%, és Kronosz jövedelme mindkét évben 60 garas. Mennyi pénzt költ el jövőre Kronosz?

\section{Eredmény Megoldás}

8. feladat: Egy fogyasztó csak kalóriacsökkentett biobrokkolit eszik, nem is költ másra pénzt. Idei $\left(x_{1}\right)$ és jövő évi $\left(x_{2}\right)$ brokkolifogyasztásra vonatkozó hasznosságfüggvénye:

$$
U\left(x_{1}, x_{2}\right)=\sqrt{x_{1}}+\frac{5}{6} \cdot \sqrt{x_{2}} .
$$

A piaci kamatláb 14\%. Egy kiló brokkoli idén 180, jövőre 190 forintba kerül. A fogyasztó jövedelme idén 32 000, jövőre 35340 forint. 
a. Legfeljebb mennyi brokkolit vásárolhat idén a fogyasztó?

b. És jövőre?

c. Adja meg a reálkamatlábat!

d. Adja meg az optimális fogyasztást!

Eredmény Megoldás

9. feladat: Dagobert idei $\left(c_{1}\right)$ és jövő évi $\left(c_{2}\right)$ fogyasztásra költött pénzre vonatkozó hasznosságfüggvénye

$$
U\left(c_{1}, c_{2}\right)=\sqrt{c_{1}}+\sqrt{c_{2}} .
$$

Dagobertnek jövedelme nincs, viszont van 100 aranykrajcárnyi megtakarítása.

a. Mekkora kamatláb mellett tenne Dagobert idén 60 aranykrajcárt a bankba?

b. És $r$ kamatláb mellett mennyit fog idén a bankba tenni?

Eredmény Megoldás

10. feladat: Ignác nehéz döntés elôtt áll: Ha aláírja a hallgatói szerződést, az állam fizeti tanulmányait, ha nem, akkor kénytelen befizetni 100 garas tandíjat. Egyetemistaként semmi keresete nincsen, de szerencsére tud olyan hitelt felvenni, amit ráér ez elsô fizetéséből megadni, ha a felvett összegre összesen 50\% kamatot fizet. Ha aláírta a hallgatói szerződést, az egyetem elvégzése utáni időszakban Piréziában kell dolgoznia, ahol 210 garas lesz a fizetése. Ha nem írja alá, akkor elmehet Óperenciába dolgozni 339 garas fizetésért. Ignác egyetem alatt $\left(c_{1}\right)$, illetve az azt követố időszakban $\left(c_{2}\right)$ fogyasztásra költött pénzre vonatkozó hasznosságfüggvénye

$$
U\left(c_{1}, c_{2}\right)=c_{1}^{4} \cdot c_{2}^{3}
$$

a. Aláírja-e Ignác a szerződést?

b. Feltéve hogy jól dönt, mennyi lesz a második időszakbeli fogyasztása?

Eredmény Megoldás 
11. feladat: Eugén és Ödön ikertestvérek, mindkettőjüknek ugyanaz a hasznosságfüggvény írja le az idei $\left(c_{1}\right)$ és a jövő évi $\left(c_{2}\right)$ fogyasztásra vonatkozó preferenciáját:

$$
U\left(c_{1}, c_{2}\right)=\ln c_{1}+\frac{4}{5} \cdot \ln c_{2} .
$$

Tudjuk továbbá azt is, hogy idén fejenként 180 krajcár a jövedelmük, jövőre pedig fejenként 162. Az egyetlen különbség, hogy Bécsben, ahol Eugén tartózkodik, 20\%-os kamatláb mellett lehet hitelt felvenni vagy betétet elhelyezni, míg Erewhonban, ahol Ödön él, egyáltalán nincsenek bankok, pénzt legfeljebb a párnahuzatban lehet tartani. Ez biztonságos, de kamatot nyilván nem fizet. A testvérek sajna nem tudnak egymásnak pénzt küldeni. A fogyasztás ára mindkét idôszakban 1 krajcár.

a. Hány krajcárt költ jövőre fogyasztásra Eugén?

b. Hány krajcárt költ idén fogyasztásra Ödön?

Eredmény Megoldás 
AZ AKTÍVÁK PIACAI 
1. feladat: Lurkó Ferkó 2009-ben beruházási céllal lakást vásárolt. A lakás az ügyvédi költséggel és az illetékkel együtt 20 millió Ft-ba került. A lakás 2010 ben, és minden azt követő évben is 1.6 - 1.6 millió Ft-tal magasabb áron adható el. A lakást ki lehet adni albérletbe, és így évi nettó 2.32 millió Ft jövedelemre lehet szert tenni. Ezt a pénzt Ferkó nem teszi bankba, hanem otthon ôrzi a páncélszekrényben, és csak a lakás értékesítésekor használja fel. (Azaz addig egyáltalán nem kamatozik.) A piaci kamatláb mindig biztosan $10 \%$.

a. Mikor (melyik év végén) érdemes eladni a lakást?

b. Vajon tud-e venni az eladás után két évvel egy másik lakást 80 millió forintért?

\section{Eredmény Megoldás}

2. feladat: Egy rekesz igazán jófajta Mama kedvence vörösbor ma $x$ garast ér, ennyiért meg is vehetem, ha akarom. Befektetésként vásárolom, azaz soha nem iszom meg, hiszen évente 6 garassal nő az értéke, de csak akkor, ha évente 1 garast költök a tárolására. A kamatláb az idők végezetéig $10 \%$-os. Mennyi ez az $x$ nagyság, ha (egyébként helyes) számításaim szerint 6 év múlva érdemes megválnom Mama kedvencétől?

Eredmény Megoldás

3. feladat: Kitûnő felmenőkkel rendelkező tenyészdisznóm, Francis Bacon, sok hasznot hozott nekem. Két éve 300000, tavaly 231000 forintnyi díjat nyert az országos disznóversenyen. Idén (hálátlanul) eladtam a vágóhídnak, 484000 forintért. A piaci kamatláb $10 \%$.

a. Ha ezt előre tudtam volna, mennyi pénzért lettem volna hajlandó eladni Bacont még közvetlenül a két évvel korábbi verseny előtt?

b. És közvetlenül a tavalyi verseny előtt?

c. És közvetlenül a tavalyi verseny után?

Eredmény Megoldás

4. feladat: Mekkora éves kifizetésú örökjáradék (jövőre fizet először, idén még nem) ér ugyanannyit, mint egy 400 garas értékú lakás, ha az éves kamatláb 5 százalék?

Eredmény Megoldás 
5. feladat: A British Textile hatástanulmánya megállapította, hogy egy évi 30 font fizetésú munkást örökre ki tudnak váltani egy 1000 font értékú géppel, amelyre ezután egyáltalán nem kell pénzt költeni. Legfeljebb mekkora a piaci kamatláb, ha ezt nem teszik meg?

Eredmény Megoldás

6. feladat: Egy ország fővárosában egy lakás ára $x$ fitying. (Az egyszerûség kedvéért nincs amortizáció, a lakás állapota nem romlik.) Az 5\%-os piaci kamatláb mellett egy lakástulajdonosnak mindegy, hogy eladja a lakást vagy évi 10000 fityingért kiadja azt. (Elhanyagolható idő alatt talál albérlőt, aki azonnal fizet.)

a. Mennyit ér a lakás?

A főváros trendi hely lesz, a tehetős emberek sorra vásárolják meg a lakásokat. A megnövekedett kereslet miatt a lakások ára 63000 fityinggel nő.

b. Mennyivel emelkednek az éves albérleti díjak?

Eredmény Megoldás

7. feladat: Van otthon egy uncia aranyam. Úgy gondolom, hogy ennek a rúpiában mért értéke a következő évek során így fog alakulni:

\begin{tabular}{ccccc} 
Most & 1 év múlva & 2 év múlva & 3 év múlva & 4 év múlva \\
\hline 795 & 880 & 965 & 1050 & 1135
\end{tabular}

Egy barátom azt mondja, hogy mostantól az örökkévalóságig fizet évente 90 rúpiát, ha neki adom az aranyat. Már ma is fizet. Belemenjek-e az üzletbe, ha a piaci kamatláb $10 \%$ ?

Eredmény Megoldás

8. feladat: Jövőre a nyersolaj hordója iránti keresletet, illetve kínálatot a

$$
D(p)=\frac{2625}{p}, \quad S(p)=25
$$

függvények adják meg, ahol az árat piréziai dinárban mérjük. Feltéve, hogy egy hordó olajat 2 dinárért tudok raktározni, a piaci kamatláb 5\%, és nincs arbitrázs, legalább mennyibe kerül idén egy hordó olaj?

Eredmény Megoldás 
9. feladat: A Phobosz-Deimosz Kft. turistákat visz Mars körüli útra. A Mars (kb.) kétévente van elég közel a Földhöz ahhoz, hogy ezt nyereségesen meg tudják tenni, ezért minden második évben 6.82 milliárd forint nyereséget termel a cég (az idők végezetéig). Az olyan években, amikor nincs Mars-utazás, 2.42 milliárd forintos veszteség keletkezik, mert a múszaki embereket továbbra is fizetni kell. A piaci kamatláb $10 \%$. Tegyük fel, hogy a Phobosz-Deimosz Kft. értéke mindig a pénzáramának a jelenértéke.

a. Mekkora a cég értéke, ha idén lesz Mars-utazás? (Idén fog nyereséget termelni a cég.)

b. Mekkora a cég értéke, ha jövőre lesz Mars-utazás? (Idén fog veszteséget termelni a cég.)

Eredmény Megoldás 
A BIZONYTALANSÁG 
1. feladat: Ön ugyan nem szenvedélyes szerencsejátékos, és nem ragad meg minden alkalmat, hogy pénzét kockára tegye, de barátja most ajánlott Önnek egy ígéretes lehetôséget, illegális fogadást köthet egy pacira, a tikett ára 144 garas. Ha nyer, visszakapja a tétjét és ezen felül 500 garast. Sajnos, ebben a kedvező esetben, azaz, ha nyer, van némi esély (pontosan 30\%) arra, hogy lebukik, ekkor nemcsak a tikett ára ugrott, hanem a nyereménye is, sôt büntetést is kell fizetnie. Mekkora a büntetés, ha Önnek jelenleg 400 garasa van, a nyerési esélye 50\%, és Önnek mindegy, belevág-e a játékba vagy sem. (A várható hasznossági függvényében vagyonának négyzetgyöke szerepel.)

\section{Eredmény Megoldás}

2. feladat (GA): Anyagi helyzetem nem túl rózsás, minden vagyonom 1 tallér. Végső elkeseredésemben minden pénzemet elköltve megvettem egy végkiárusításon az utolsó sorsjegyet. Ha nyerek - ennek valószínúsége 50\% - a sorsjegy árának négyszeresét kapom, egyébként semmit. Az utóbbi napokban azonban elbizonytalanodtam, jó vásárt csináltam-e? Ezért felkerestem gazdag barátomat, akinek vagyona 2 tallér, és imádja a szerencsejátékot, ami abból is kiderül, hogy hasznossága vagyonának négyzete (csak nemnegatív vagyonértékeken értelmezve). Felajánlottam neki megvételre a sorsjegyet, de szeretném érte teljes vagyonát megkapni. Vajon hajlandó-e barátom 2 tallért fizetni az említett sorsjegyért?

\section{Eredmény Megoldás}

3. feladat (GA): Egon épp most végzett a Közgázon, úgyhogy ideje, hogy elkezdje tervezni a jövőjét. Két lehetőség áll előtte. Az egyik, hogy „becsületes” szakmát választ, és pénzmosással 1 milliót keres évente (természetesen ezzel nem bukhat le). Ezt a munkát kiváló diplomájára való tekintettel akármikor elkezdheti.

A másik lehetőség, hogy friss diplomájával a kezében elmegy bankot rabolni. A bankban 40 millió forint van, $p$ eséllyel nem kapják el, viszont csak egyszer próbálkozhat. Ha nem kapják el, egy életen keresztül lógázza a lábát. Ha elkapják, elveszik a pénzt, és 20 év kényszermunkára ítélik (ahol nem keres). Szabadulása után szakmájában dolgozhat, ha úgy gondolja.

Egon úgy számol, hogy még 60 évig fog élni. Hasznossági függvénye

$$
U(x, y)=x y
$$

alakú, ahol $x$ az élete során megkeresett pénzt, $y$ pedig a ,nem börtönben, de nem is munkával” töltött évek számát jelenti. Egon a várható hasznosságát maximalizálja.

a. Milyen $p$ érték mellett dönt a bankrablás mellett? 
b. Milyen $p^{\prime}$ esetén rabolna, ha 40 helyett 90 millió lenne a bankban?

\section{Eredmény Megoldás}

4. feladat: Mázlis-Lusta Bélát egyáltalán nem érdekli a kockázat, annál inkább szeret lustálkodni. Hasznossági függvénye $U(R, E)=R E$, ahol $R$ az egy év ötvenkét hetébool lustálkodással eltöltött hetek száma, $E$ pedig jövedelmének várható értéke. Bélának két lehetôsége van, ezek közül most kell választania. Az egyik, hogy dolgozik annyit, amennyit akar, $w$ heti munkabér mellett, a másik, hogy nem dolgozik semmit, de bácsikája befizet neki egy szerencsjátékra, amin 75\%-os valószínúséggel egy fityinget sem nyer. Szerencsés esetben azonban $X$ tallér üti a markát. Hány heti munkabére a nyeremény, ha Bélának mindegy, melyik opciót választja?

\section{Eredmény Megoldás}

5. feladat: Ön várható hasznát maximalizálja, a várható hasznosság függvényében vagyona négyzetgyöke szerepel. A mostani 120 garas vagyona mellett piszok szerencséje van: választhat a következő két - egymást kizáró - lehetőség közül. Vagy vásárolhat 20 garasért egy sorsjegyet, amivel 50\%-os valószínúséggel nyerhet 300 garast (50\%-os valószínúséggel pedig semmit), vagy 50 garas ellenértékért cserébe megkaphatja egy, a jövő évtől évi 15 garast fizető örökjáradék jelenértékét, amit most rögtön kifizetnek Önnek. A kamatláb minden évben $10 \%$-os.

a. Melyik lehetőséget választja?

b. Mennyit lenne hajlandó fizetni maximum az örökjáradékért, ha mindegy, melyiket választja?

Eredmény Megoldás

6. feladat: Jelenlegi vagyona 225 aranygaras, de részt vehet egy szerencsejátékban, ahol $p$ valószínúséggel nyerhet 175 aranygarast, de persze veszíthet is, mégpedig 81 aranygarast. Ön várható hasznát maximalizálja, hasznossági $N$ - $M$-függvényében vagyonának négyzetgyöke szerepel. Kis gondolkodás után arra a következtetésre jut, hogy mindegy, részt vesz-e a játékban vagy sem.

a. Mekkora a $p$ értéke?

b. Vajon fizetne-e 44 aranygarast azért, hogy a játékbeli nyerési esélyét 50\%-ra emeljék?

Eredmény Megoldás 
7. feladat: Nyuszika a vagyonát két pénzügyi eszközben tartja: Egyrészt van pénztárcájában 289 euró, ez mindenképp nála marad. Másrészt adott pénzt a Black-Scholes vagyonkezelőnek, akik ezért cserébe portfóliót készítenek a számára. A vagyonkezelő nagy várható hozamot ígér, de kockázatos cégekbe fektet, ezért nagy veszteség is elképzelhető. Nyuszika számára három portfóliót kínálnak:

1. Mindent egy lapra:

Ez a portfólió az $A$ cég részvényeiből vásárol. A részvények értéke egy hónap múlva $50 \%$ eséllyel 0 euró, $50 \%$ eséllyel 672 euró.

2. Diverzifikált (magyarul: változatossá tett):

Ez a portfólió az $A$ és $B$ cég részvényeiből vásárol. A portfólióban az $A$ cég részvényeinek értéke egy hónap múlva $50 \%$ eséllyel 0 euró, $50 \%$ eséllyel 336 euró. A $B$ cég részvényeinek értéke ugyanígy egy hónap múlva $50 \%$ eséllyel 0 euró, $50 \%$ eséllyel 336 euró. E cégek részvényárfolyamai egymástól teljesen függetlenek, így $25 \%$ annak a valószínúsége, hogy mindkét részvény értéktelen, 25\% annak a valószínúsége, hogy az $A$ részvény értékes és a $B$ részvény értéktelen stb.

3. Fedezett (angolul: ,hedged”):

Ez a portfólió az $A$ és $C$ cég részvényeiből vásárol. A portfólióban az $A$ cég részvényeinek értéke egy hónap múlva $50 \%$ eséllyel 0 euró, $50 \%$ eséllyel 336 euró. A $C$ cég részvényeinek értéke ugyanígy egy hónap múlva $50 \%$ eséllyel 0 euró, $50 \%$ eséllyel 336 euró. E cégek részvényárfolyamai nem függetlenek egymástól, sôt mindig épp ellentétes irányban mozognak. Vagyis, ha az $A$ részvény értéktelen, akkor a $C$ részvény értékes, ha az $A$ részvény értékes, akkor pedig a $C$ értéktelen.

a. Adja meg Nyuszika vagyonának (készpénz + részvények) a várható értékét az 1., 2. és 3. portfólió mellett!

Nyuszika hasznosságfüggvényében vagyona egy hónappal későbbi értékének a négyzetgyöke szerepel.

b. Adja meg Nyuszika várható hasznosságát az 1., 2. és 3. portfólió mellett!

c. Melyik portfóliót választja Nyuszika?

Eredmény Megoldás 
8. feladat: Chirrut az utolsó előtti vizsgaalkalmon elégtelennél jobb, jelesnél rosszabb jegyet szerzett a Gazdasági és Pénzügyi Matematika nevú tárgyból. Azon gondolkozik, elmenjen-e az utolsó vizsgára javítani. (Ez esetben a korábbi jegye érvénytelen.) Úgy gondolja, hogy a javítóvizsgán 10\% valószínúséggel jeles(5), 20\% valószínúséggel jó(4), 30\% valószínúséggel közepes(3), 30\% valószínúséggel elégséges(2) és $10 \%$ valószínúséggel elégtelen(1) érdemjegyet szerezne.

a. Ha elmegy javítani, mennyi a javítóvizsgán szerzett osztályzat várható értéke?

Chirrut hasznosságfüggvényében a tárgyból kapott jegy négyzete szerepel. Elmegy-e javítani, ha az első vizsgán szerzett jegye

b. elégséges?

c. közepes?

d. jó?

e. Mekkora Chirrut számára a javítóvizsgán szerzett bizonytalan jegy biztos egyenértékese?

Eredmény Megoldás

9. feladat: Robin kezdő rabló. Azért lett az, mert mindössze 25 arany vagyona van. Az elsố rablása során az áldozata, John, elôveszi pénztárcáját, de ahelyett, hogy átadná azt, megmutatja, hogy 200 arany van benne. Felajánlja, hogy ad ebből 75-t, és menjenek mindketten békében. Ha viszont Robin visszautasítja az ajánlatot, akkor John ellenáll, $40 \%$ eséllyel le is gyưri Robint, és elveszi a 25 aranyát. Robin hasznosságfüggvényében vagyonának négyzetgyöke szerepel.

a. Elfogadja-e Robin az ajánlatot?

Miután Robin optimális döntést hozott, belefut következő áldozatába, Tuckba. Tuck Johnnál kisebb, dulakodás esetén $80 \%$ annak az esélye, hogy Robin nyer. Robinnál az előzô rablás eredménye, Tucknál 300 arany van, verekedés esetén a győztes mindent visz.

b. Mi az a legkisebb ajánlat, amit Robin elfogad dulakodás helyett?

Eredmény Megoldás 
10. feladat: Egy golfverseny közben ismerősömmel fogadtunk a nyertesre. Amelyikőnknek igaza van, kap a másiktól 50 dollárt. A téten kívül egyikőnknek sincs pénze, és mindkettőnk hasznosságfüggvényében a vagyon négyzetgyöke szerepel. A verseny még nem dőlt el, amikor ismerősöm a következő ajánlatot tette: fújjuk le a fogadást, cserébe ad 14 dollárt.

a. Mit gondolt ismerősöm, legalább mekkora eséllyel veszít?

b. Elfogadjam-e az összeget, ha úgy gondolom, hogy ismerősöm $80 \%$ eséllyel fog veszíteni?

\section{Eredmény Megoldás}

11. feladat: Forex Fern nem szeret sokat dolgozni, de nagyon okosnak tartja magát, ezért devizával kereskedik az interneten. Reggel átvált $m$ forintjából valamennyit délafrikai randra(ZAR), 25 HUF/ZAR árfolyamon, és este az összes randot visszaváltja forintra. Tranzakciós díj nincs. Úgy gondolja, hogy este az árfolyam 51\% valószínûséggel 26 HUF/ZAR és 49\% valószínúséggel 24 HUF/ZAR lesz. Hány forintja van a reggeli átváltás előtt Fernnek, ha hasznosságfüggvényében a vagyona négyzetgyöke szerepel és optimumban 100 randot vesz?

\section{Eredmény Megoldás}

12. feladat: Marcónak tegnapig 60 dollár volt minden vagyona, de ma 300 részvényt örökölt. Marco szeretné ezeket is pénzzé tenni két napon belül. A részvényeket ma 6 dolláros áron lehet eladni, de az árfolyam egy folyamatban lévő felvásárlás miatt holnapra megváltozik. Ha a felvásárlás sikeres, az árfolyam 15 dollárra emelkedik, ha sikertelen, akkor pedig 5 dollárra csökken. A felvásárlás $10 \%$ valószínúséggel sikeres, 90\% valószínúséggel sikertelen. Marco hasznosságfüggvényében a vagyona természetes logaritmusa szerepel, és várható hasznosságát maximalizálja.

a. Mennyit ér Marco vagyona sikeres felvásárlás esetén?

b. Hány részvényt ad el a mai 6 dolláros árfolyamon?

\section{Eredmény Megoldás}

13. feladat: A waterlooi csata alatt káosz uralkodik a brit államkötvények piacán. Lord Keynes úgy véli, a francia győzelem valószínúsége 50\%, és ugyanekkora eséllyel győznek a szövetséges csapatok. A jelenleg 1 fontos árfolyamon kapható brit államkötvény francia győzelem esetén értéktelenné válik, ellenkező esetben 3 fontot fog érni. 
(Több eset nincs.) Lord Keynesnek 50 fontja van, és hasznosságfüggvényében a vagyona négyzetgyöke szerepel.

a. Hány fontért vásárol államkötvényt Lord Keynes?

b. Ha még nem vásárolt kötvényeket, hajlandó lenne-e 14 fontot fizetni azért, hogy a piac előtt megtudja a csata kimenetelét? Ezután még 1 fontos áron tud kötvényt venni, ha akar.

Eredmény Megoldás 
TECHNOLÓGIA 
1. feladat: Legyen egy vállalat termelési függvénye

$$
y=\left(x_{1}^{a} x_{2}^{a}\right)^{2}
$$

alakú, ahol $a$ pozitív konstans.

a. Az a paraméter mely értékeire lesz a technikai helyettesítési határarány értékének abszolút értéke növekvő? (Segítség: használja fel a fogyasztó elméletében tanultakat analógiaként!)

b. Az a paraméter mely értékeire lesz a mérethozadék növekvő?

Eredmény Megoldás

2. feladat: Legyen egy vállalat termelési függvénye

$$
y=x_{1}^{a}+x_{2}^{a}
$$

alakú, ahol $a$ pozitív konstans.

a. Az a paraméter mely értékeire lesz a technikai helyettesítési határarány értékének abszolút értéke csökkenő?

b. Az a paraméter mely értékeire lesz a mérethozadék növekvő?

Eredmény Megoldás

3. feladat: Mit mondhatunk a következő termelési függvényekkel megadott technológiák mérethozadékáról?

a.

$$
y=\left(K^{1 / 2}+L^{1 / 2}\right)^{3},
$$

b.

$$
y=\left(K^{1 / 3}+L^{1 / 3}\right)^{2},
$$

c.

$$
y=(2 K+3 L)^{1 / 2} .
$$

Eredmény Megoldás 
4. feladat: Greasy Joe hotdogja három alapanyagból készül: kell egy óriáskifli és 10 dkg disznó- vagy baromfihús. Joe raktárában 10 kifli, 80 dkg disznóhús és 40 dkg baromfihús van.

a. Ilyen készlet mellett mennyi az óriáskifli határterméke?

b. Mennyi a disznóhús határterméke?

c. Mennyi a baromfihús határterméke?

d. Mi a kifli és disznóhús közti technikai helyettesítési határarány?

e. Mi a disznó- és baromfihús közti technikai helyettesítési határarány?

Joe kutyája suttyomban elfogyaszt 20 dkg disznóhúst.

f. Mennyi most az óriáskifli határterméke? És a húsoké?

Eredmény Megoldás 


\section{PROFITMAXIMALIZÁLÁS}


1. feladat: A Rózsa Sándor Bt. karikásostorokat gyárt. A bt. termelési függvénye $y=a^{1 / 2}+b^{1 / 2}$, ahol $y$ a legyártott ostorok, $a$ a felhasznált akácfa és $b$ a felhasznált bôr mennyisége. A cég a profitját maximalizálja, de sajnos csak 169 egység akácfa áll rendelkezésére egységenként gyakorlatilag elhanyagolható áron, több még pénzért sem. (Ennyit mindenképpen felhasznál.) Egy egység bőr 2 garas, egy ostor pedig 20 garasért értékesíthető.

a. Hány egység bőrt használ fel a Rózsa Sándor Bt.?

b. Hány ostort gyárt?

c. Mekkora a profitja?

Eredmény Megoldás

2. feladat: Egy tökéletesen versenyző vállalat mindig rögzített arányban használja fel a termelési ráfordításokat: termelési függvénye

$$
y=\left(\min \left\{5 x_{1}, 3 x_{2}\right\}\right)^{1 / 3}
$$

alakú. Ha az első termelési tényezó ára 5 garas, a másodiké 6 garas, akkor adja meg a cég kínálati függvényét (a termék $p$ árának függvényében)!

Eredmény Megoldás

3. feladat: Az AKIÉ magyar bútoráruház bútorokat gyárt fából, termelési függvénye: $y=\sqrt{x}$. Egy bútor 6 milpengőbe kerül, a fa egysége 3 milpengő, mindkettő folytonos jószág. Mi az AKIÉ profitmaximalizáló termelése?

Eredmény Megoldás

4. feladat: Egy autóalkatrész-gyár a termelés során két inputot használ, tőkét $(K)$ és munkaerőt $(L)$. A termelési függvénye: $f(K, L)=4 \cdot K^{1 / 4} \cdot L^{1 / 2}$. Az alkatrész ára 3 garas, a tôkejáradék (ez a tôke ára) 2 garas, a munkabér 1 garas.

a. Mennyi a gyár által elérhetô maximális nyereség?

b. Mennyi az optimumban a technikai helyettesítési ráta?

c. Mi a tőkére vonatkozó tényezőkeresleti függvény $p$ (termékár), $r$ (tőkejáradék) és $w$ (munkabér) függvényében?

Eredmény Megoldás 
5. feladat: Egy internetszolgáltató telefonos ügyfélszolgálaton két dologra van szükség: informatikusokra és telefonos munkatársakra. E kollégák szakértelmei nem helyettesítik egymást, a szolgáltatáshoz mindkettő elengedhetetlen. Ahhoz, hogy y problémát megoldjanak, $\frac{y^{2}}{2}$ informatikusra és $y^{2}$ telefonos munkatársra van szükség. A megoldott problémák egyenként $p$ garast érnek a vállalatnak. (Persze nem fizet a betelefonáló, de a közgazdászok szerint az elégedettsége ennyivel növeli a vállalat profitját, mert különben az ügyfél lemondaná az előfizetését.) Egy informatikus fizetése $w_{i}$, egy telefonos munkatársé 1 garas.

a. Adja meg a termelési függvényt!

b. Mennyi az első input határterméke az $\left(x_{1}, x_{2}\right)=(10,10)$ pontban?

c. Mi a vállalat által elérhető maximális profit, ha $p=8, w_{i}=2$ ?

d. Hány informatikai szakértőt vegyen fel a vállalat ( $p$ és $w_{i}$ függvényében)?

Eredmény Megoldás

6. feladat: Visszatérve a 4. feladathoz: egy autóalkatrész-gyár a termelés során két inputot használ tőkét $(K)$ és munkaerôt $(L)$. A termelési függvénye: $f(K, L)=$ $4 \cdot K^{1 / 4} \cdot L^{1 / 2}$. A tôkejáradék (ez a tőke ára) 2 garas, a munkabér 1 garas. Egy autóalkatrész ára eddig 3 garas volt, a gyár emellett optimalizált, ez alapján rendelte meg az inputmennyiségeket. Az alkatrészek ára azonban hirtelen 2 garasra esik. A vállalat elbocsáthat vagy felvehet új munkaerőt, de rövid távon a tőke mennyisége rögzített. (A már befektetett tőke még nem amortizálódott, és időbe telik új beruházást megvalósítani.)

a. Optimumban hány munkást alkalmaz a vállalat?

b. Mennyi a rövid távon elérhetô maximális profit?

Az alkatrészek ára hosszú távon is 2 garas marad. De ilyen időhorizonton a gyár szabadon dönthet mind az általa felhasznált tôke, mind a munkaerő mennyiségéről.

c. Mennyi a hosszú távon elérhető maximális profit?

Eredmény Megoldás 
KÖLTSÉGMINIMALIZÁLÁS 
1. feladat: Két, egymással véres harcban álló, versenyző cég ugyanazt a terméket (gombfocicsapatot) gyártja. Mindkettő termelési függvénye $y=\min \left\{2 K^{1 / 2}, 2 L^{1 / 2}\right\}$, ahol $K$ a felhasznált tôkét, $L$ a felhasznált munkát jelöli. A munkabér mindkét cég számára 1 garas, a tôke egységének bérleti díja (teljes költsége) 4 garas.

a. Adja meg a cégek költségfüggvényét a termelés függvényében!

Az elsô cég a lehető legolcsóbb módon termel, és 20 csapatot gyárt egy nap. A második cég gazdasági vezetője (szociális szempontból) ragaszkodik ahhoz, hogy legalább háromszor annyi munkást alkalmazzon, mint az elsô cég.

b. Mennyivel nagyobb a második cég összköltsége, ha termelése 30 ?

Eredmény Megoldás

2. feladat: Egy versenyzői vállalat székeket gyárt. Ehhez csak fát $(T)$ és munkaerốt $(L)$ használ fel. Termelési függvénye: $y=F(T, L)=(T \cdot L)^{1 / 4}$. A szék piaci ára $p=16$. Az egyes inputok ára: $w_{T}=1, w_{L}=4$, más költség nincs is. Sajnos a helyi asztalos szakszervezetek miatt a vállalat csak úgy tudott munkaerőhöz jutni, ha felvette az összes munkát vállaló asztalost, szám szerint tizenhatot. Ezt szerződésben rögzítették, így megmásíthatatlan.

a. Írja fel a vállalat rövid távú költségfüggvényét!

b. Mennyi az optimális fafelhasználás és a profit?

A szakszervezet belső ellentétek miatt felbomlott, a szerződések érvényüket vesztették. Így a vállalat megválaszthatja a felhasznált munka mennyiségét.

c. Mennyi most az optimális fa- és munkafelhasználás, és mennyi a profit?

Eredmény Megoldás

3. feladat: Az Egyen otthon! vállalat egy ebédet $20 \mathrm{dkg}$ disznóhúsból és $25 \mathrm{dkg}$ krumpliból (paprikás krumpli) vagy 25 dkg csirkehúsból és 20 dkg rizsből (currys csirke) tud előállítani. A disznóhús, csirkehús, krumpli és rizs kilónkénti ára rendre: 1500 $\mathrm{Ft}, 800 \mathrm{Ft}, 160 \mathrm{Ft}, 250 \mathrm{Ft}$.

a. Adja meg a termelési függvényt!

b. Mennyi pénzből tud az Egyen otthon! 10 adag ebédet előállítani? 
c. Hogy változik a fenti összeg, ha a vállalat már elkötelezte magát amellett, hogy minden alapanyagból legalább 1 kg-ot vegyen?

Eredmény Megoldás

4. feladat: Egy vállalat kénsavból $\left(x_{1}\right)$ és rézből $\left(x_{2}\right)$ akkumulátorokat állít elő. Egy liter kénsavból és $\alpha$ kilogramm rézből $\alpha$ darab akkumulátort lehet előállítani. Az inputokat nem lehet egymással helyettesíteni, csak ilyen arányban lehet felhasználni ôket. Egy liter kénsav kettő, egy kiló réz egy dollárba kerül.

a. Adja meg a termelési függvényt!

b. Mennyi $\alpha$, ha a vállalat költségfüggvénye $C(2,1, y)=\frac{10}{\alpha} \cdot y$ ?

c. Milyen mérethozadékú a technológia?

Eredmény Megoldás

5. feladat: Egy hőerômú energiatermelésében a feketeszén és a lignit tökéletes helyettesítők. A technológia állandó mérethozadékú, a feketeszén energiaértéke kétszerese a lignitének. Ugyanakkor a lignit tonnájának ára csak 20 dollár, míg a feketeszéné 50 dollár. Fix költség nincs.

a. Mi a vállalat költségfüggvénye? (1t lignit energiája/dollár)

Az előző igazgató által kötött szerződések miatt a vállalat jövőre pontosan 3 tonna feketeszenet vásárol, a fenti áron.

b. Mi a rövid távú költségfüggvény?

Tegyük fel, hogy az előző igazgató nem 3 , hanem $\bar{x}_{1}$ tonna feketeszenet vásárolt, és csak annyit tudunk, hogy a rövid távú költségfüggvény elég nagy energiamennyiség esetén

$$
C_{s}\left(50,20, y, \bar{x}_{1}\right)=20 \cdot y+70 \text {. }
$$

c. Mennyi $\bar{x}_{1}$ ?

Eredmény Megoldás 
6. feladat: Egy vállalat termelési technológiája

$$
f\left(x_{1}, x_{2}\right)=x_{1} \cdot x_{2}^{2} .
$$

A második inputtényező ára 5 dollár.

a. Milyen mérethozadékú a technológia?

b. Mennyit használnak el költségminimumban az első inputtényezőből y és $w_{1}$ függvényében?

c. Mennyi a vállalat összes költsége, ha tudjuk, hogy költségminimumban $x_{2}^{*}=40 ?$

d. Adja meg a vállalat költségfüggvényét $y$ és $w_{1}$ függvényében!

e. A c. pontban szereplő költségminimumban $y=40000$. Mennyi $w_{1}$ ?

f. $w_{2}=5, \bar{x}_{2}=40$ és a $w_{1}$ e. pontbeli értékének változatlanságát feltételezve, mi a vállalat rövid távú költségfüggvénye?

Eredmény Megoldás 
KÖLTSÉGGÖRBÉK 
1. feladat: A diákétkeztetésben sláger a krumplistészta. Kétféle módon lehet elkészíteni, attól függően, hogy kevergetjük vagy kavargatjuk. (Az eljárásokat nem tudjuk kombinálni sajnos.) A keverés esetén a termelési függvény: $y=(\min \{k, l\})^{1 / 2}$, ahol y a krumplistésztaadagok száma, $k$ a keverőlapátoké, $l$ pedig a lapátkeveróké. Egy keverőlapát 1 garasba, egy lapátkeverő 4 garasba kerül. A kavaráshoz - az előállított krumplistészta mennyiségétôl függetlenül - kell egy kavarógép, ennek ára 6 garas. Kavaráskor a krumplistésztaadagok határköltsége $M C(y)=2 y-2$.

a. Írja fel a krumplistészta-termelés teljesköltségfüggvényét!

b. Mennyi ennek értéke az $y=1 / 2$, illetve az $y=2$ pontban?

c. Írja fel a krumplistészta-termelés határköltségfüggvényét!

Eredmény Megoldás

2. feladat: Egy képeket üzemi mennyiségben termelő festômúvész határköltségfüggvénye $M C_{A}(y)=2 \cdot y$. Fix költsége nincs.

a. Adja meg a festő költségfüggvényét!

Egy új technikának köszönhetően, ha a festő befektet 50 dollárt, határköltségfüggvénye $M C_{B}(y)=y$-ra változik.

b. Legalább mekkora kibocsátás mellett éri meg befektetnie?

c. Ezt figyelembe véve adja meg a festő költségfüggvényét! (Mi az a legkisebb költség, amivel elő tud állítani $y$ festményt?)

Eredmény Megoldás

3. feladat: Egy vállalat költségfüggvénye:

$$
c(y)=y^{2}+8 \cdot y+25 .
$$

a. Hol van az átlagköltségfüggvény minimuma?

b. És mennyi ez?

c. Tegyük fel, hogy a vállalat $p=15$ ár mellett tud termelni. Lehet nyereséges a vállalat? 
d. Hol van az átlagos változóköltség-függvény minimuma?

e. És mennyi ez?

Eredmény Megoldás

4. feladat: Egy vállalat költségfüggvénye:

$$
c(y)=y^{3}-4 \cdot y^{2}+12 \cdot y+25 .
$$

a. Hol van az átlagos változóköltség-függvény minimuma, és mennyi ez?

b. Mi az a legkisebb $p$ ár, amely mellett nem (csak) nulla kibocsátás mellett maximális a profit?

Eredmény Megoldás

5. feladat: Egy vállalat átlagos változóköltség-függvénye:

$$
A V C(y)=y+6 .
$$

A termelés során adódik még 25 egység fix, és 144 egység kvázifix költség.

a. Adja meg a költségfüggvényt!

b. Hol van az átlagköltségfüggvény minimuma, és mennyi ez?

c. Mi az a legkisebb $p$ ár, ami mellett nem lesz veszteséges a vállalat?

d. Hol van az átlagos változóköltség-függvény minimuma, és mennyi ez?

e. Mi az a legkisebb $p$ ár, ami mellett nem (csak) nulla kibocsátás mellett maximális a profit?

Eredmény Megoldás

6. feladat: A Jürgen Peter Morgen Zrt. pénzügyi tanácsokat ad ügyfeleinek. Ehhez üzleti stratégiai szakértőkre és irodákra van szüksége. Konkrétan $s$ szakértő és $i$ iroda segítségével $\sqrt[3]{s \cdot i}$ ügyfelet tudnak kiszolgálni. Egy szakértő fizetése 2000 euró, egy iroda bérleti díja 4500 euró. 
a. Legolcsóbban hány euróból tud a Zrt. y ügyfelet kiszolgálni?

A profitmaximálizáló Jürgen Peter Morgen Zrt. ügyfelenként 54000 eurós díjat kérhet a tanácsokért.

b. Hány ügyfelet szolgál ki a vállalat, és összesen mekkora költséggel teszi ezt?

A Jürgen Peter Morgen Zrt. új irodaházat építtetett Piréziában. Így most van 200 darab irodája. Ha akarja, ezeket vagy egy részüket ingyen használhatja a tanácsadás során, de a nem használt irodákat ki is adhatja a piaci áron (4500 euró). A Jürgen Peter Morgen a tanácsadásból és irodakiadásból származó hasznának az összegét maximalizálja.

c. Hány ügyfelet szolgál ki most vállalat, és összesen mekkora költséggel teszi ezt?

Eredmény Megoldás 
VÁLLALATI KÍNÁLAT 
1. feladat: Egy kompetitív (profitmaximalizáló, árelfogadó) cég határköltségfüggvénye a $(0,2)$ pontból induló félegyenes. A fedezeti pontjában változó költsége 24 egység, és a termelői többlete 16 egységgel több, mint az üzembezárási pontban. Adja meg a cég teljesköltség-függvényét!

Eredmény Megoldás

\section{2. feladat:}

Egy gombfocikapukat gyártó, árelfogadó cég költségfüggénye

$$
c(y)=2 y^{2}+a y+18
$$

alakú. Ha a gombfocikapu ára 23 garas, akkor a cég profitja 32 garas.

a. Mekkora az a paraméter értéke?

b. Hány kaput termel a cég, ha a bevétele éppen fedezi a költségeit?

c. Mekkora az a legmagasabb ár, amely mellett nem termel?

\section{Eredmény Megoldás}

3. feladat (GA): A diós-mákos csemege titkos receptjéról csak a következőket sikerült megtudni: „Végy valamennyi diót és valamennyi mákot. Ha több mákot használsz, mint diót, akkor az elkészült csemege mennyisége a felhasznált dió mennyiségének négyzetgyöke. Ha viszont több diót használsz, mint mákot, akkor az elkészült csemege mennyisége a felhasznált mák mennyiségének négyzetgyöke."

Tegyük fel, hogy a csemegét egy árelfogadó profitmaximalizáló vállalat gyártja, amely a termeléshez szükséges eszközöket megvette, ennek költsége a termeléstől függetlenül 500 tallér. A dió ára 14, a mák ára 16 tallér.

a. Írja fel a vállalat költségfüggvényét!

b. Mennyit termel a vállalat, ha a csemege piaci ára 600 tallér?

c. Adja meg a csemege piaci árának azon értékeit, amelyek mellett a vállalat nem termel!

Eredmény Megoldás 
4. feladat: Egy tökéletesen versenyző vállalat költségfüggvénye:

$$
C(y)=y^{2}+2 y+100 .
$$

a. Mekkora a fedezeti pontban a termelése?

b. Mekkora az a minimális ár, amely mellett rövid távon pozitív mennyiséget termel?

c. Adja meg az optmiális profitját a $p$ ár függvényében!

Eredmény Megoldás

5. feladat: Egy vállalat költségfüggvénye $y^{3}-4 \cdot y^{2}+12 \cdot y+25$.

a. Adja meg a vállalat üzembezárási pontját!

b. Adja meg a vállalat kínálati függvényét!

Eredmény Megoldás

6. feladat: Egy vállalat változóköltség-függvénye $y^{2}+2 \cdot y$, és ha $p=4$, akkor a vállalat a fedezeti pontjában termel.

a. Mennyi a vállalat fix költsége?

b. Adja meg a vállalat üzembezárási pontjához tartozó árat!

c. Mi a vállalat kínálati függvénye?

Eredmény Megoldás

7. feladat: Egy gyurmagyár konstans határköltséggel termel gyurmát. Amikor egy adag gyurma piaci ára 12 fabatka, 7 gyurma kibocsátása maximalizálja a gyár profitját, és ez a maximális profit -6 fabatka.

a. Mi a gyár költségfüggvénye?

b. Mi a gyár kínálati függvénye?

Eredmény Megoldás 
8. feladat: Egy textilipari vállalatnak kétfajta költsége van: egyrészt fizetnie kell munkásait, másrészt pedig anyagot kell beszereznie termékei gyártásához. A munkások 36 dollárnyi munkabérét már kifizette a vállalat, és y egységnyi termék előállításához szükséges anyag költsége $y^{2}$.

a. Mi a vállalat kínálati függvénye?

b. Mennyi hasznot termel 10 dolláros ár mellett?

c. Feltéve, hogy a munkabéreket még nem fizették ki, és ez kvázifix költségnek számít, mi a vállalat kínálati függvénye?

Eredmény Megoldás

9. feladat: Az Elókelő Szaft nevư étteremben szarvashúsból készült fogásokat készítenek és szolgálnak fel a vendégek számára. A hús közvetlenül a vadászoktól vásárolják, kilónként $w$ garasért. Az egyszerúség kedvéért csak egy fogást lehet venni az étteremben, ennek ára $p$. Az étterem összköltsége, ha $y$ darab fogást ad el

$$
C(y, w)=\left\{\begin{aligned}
256, & \text { ha } y=0 ; \\
y^{2}+w \cdot y+400, & \text { ha } y>0 .
\end{aligned}\right.
$$

A jelenlegi $p$ ételár és a $w$ hús tényezőár mellett a profitmaximalizáló étterem 84 garas nyereséget termel, de ha 25\%-kal többet kellene fizetni a hús kilójáért, akkor mindegy lenne neki, hogy termel-e vagy bezár.

a. Mennyibe kerül most egy kiló szarvashús?

b. Mi a fedezeti ponthoz tartozó ár?

Eredmény Megoldás 
IPARÁGI KÍNÁLAT 
1. feladat: Határmente lakóinak kedvenc étele a katyvasz, a kedvelt csemege iránti inverz kereslet függvénye: $p=a-2 Y$. A faluban pontosan 10 katyvasztermelô mûködik, mindegyik árelfogadó, profitmaximalizáló vállalkozás. Azért nem több, mert a korábbi korrupt polgármester pontosan ennyi engedélyt bocsátott ki. Egy termelő költségfüggvénye: $c(y)=4+12 y+y^{2}$. Az újonnan megválasztott polgármester azonban a következőképpen gondolkodik: „Ha kihirdetem, hogy ezentúl az gyárt katyvaszt a faluban, aki csak akar, akkor - mivel ez sérti a jelenlegi termelők érdekeit - ezek bizonyára nem sajnálnának egy kis pénzt arra, hogy rábírjanak a jelenlegi szabályozás fenntartására.” A polgármesternek sajnos igaza van.

a. Mekkora az a paraméter értéke, ha egy cég maximum 12 garast áldozna erre a „,nemes” célra?

b. Hány új cég lépne be a piacra, ha a polgármester meggondolná magát, és lelkiismerete megnyugtatására mégis feloldaná a korlátozást?

\section{Eredmény Megoldás}

2. feladat: Egy kompetitív iparágban pillanatnyilag 100 vállalat tevékenykedik. Valamennyi rövid távú teljes költségfüggvénye:

$$
T C(q)=20+200 q+15 q^{2} .
$$

Az iparági inverz keresleti függvény: $P=400-0.1 Q$. ( $Q$ az iparági keresett mennyiséget, $q$ egy vállalat termelését, $P$ pedig a termék egységárát jelzi.) Mi lesz az iparágban az egyensúlyi ár és az össztermelés?

\section{Eredmény Megoldás}

3. feladat: Infantiliában nem gyárthat bárki gombfocipályát, csak az, aki leperkál 100 garast a gyártási engedélyre. A termelés költségfüggvénye ez után $c(y)=y^{2}+4 y$, ahol $y$ az egy termelő által gyártott gombfocipályák száma. A pályák iránti inverz keresleti függvény: $p=124-b Y$, ahol $Y$ az összes eladott pálya száma. Mekkora a $b$ paraméter értéke, ha hosszú távú egyensúlyban pontosan 10 árelfogadó termelő gyártja a pályákat?

\section{Eredmény Megoldás}


4. feladat: A kergebirka kompetitív piaca hosszú távú egyensúlyban van, a pontosan zérus profitot elérô 10 vállalat (egyedi) költségfüggvénye

$$
c(y)=25+c y+4 y^{2},
$$

ahol y a vállalat által megtermelt kergebirka mennyisége. Az iparági inverz keresleti függvény $p=72-2 Y$, ahol $Y$ a piacon keresett összes kergebirka mennyisége.

a. Mennyit termel egy vállalat?

b. Mekkora a hosszú távú egyensúlyi ár?

c. Mekkora ebben az egyensúlyban egy vállalat változóköltsége?

Eredmény Megoldás

5. feladat: Magyarországon tetszőleges vállalat

$$
C(y)=\left\{\begin{array}{cl}
0, & \text { ha } y=0 \\
y^{2}+392 \cdot y+100, & \text { ha } y>0
\end{array}\right.
$$

forintban mért költséggel termelhet $y$ kiló mogyorót. Persze az itthon kapható földimogyorót nem mind itthon termesztik, Hollandiából akár 5000 kiló mogyorót is lehet importálni, ha megfizetik a legalább 300 forint/kilós árát.

a. Ha 400 forintba kerül egy kiló mogyoró, hány kiló mogyorót termel egy magyar vállalat?

b. Feltéve, hogy rövid távon pont 6 magyar vállalat termel mogyorót (ők már kifizették a kvázifix költséget is, számukra fix), adja meg a $p$ ft/kg mogyoró ár függvényében a magyarországi vállalatok által kínált mogyorók mennyiségét!

c. Hány magyar vállalat lesz hosszú távú egyensúlyban a piacon, ha a keresleti függvény

$$
D(p)=10000-5 \cdot p ?
$$

Eredmény Megoldás 
6. feladat: Egy városban az organikus paleo kóla iránti keresleti függvény:

$$
D(p)=320-p .
$$

Egy megfelelő üzlethelyiség bérlése 100 euróba kerül, ezenkívül a kólagyártás költségfüggvénye

$$
C(y)=y^{2} .
$$

Minden vállalkozás árelfogadó módon viselkedik, és persze saját profitját maximalizálja.

a. Mi az a legnagyobb profit, amit egy vállalat adott $p$ ár mellett elérhet ( $p$ nem feltétlen egyensúlyi, kezelje paraméterként)?

b. Mi egy vállalat $p$ ár melletti kínálati függvénye, ha még nem bérelte ki az üzlethelyiséget?

c. Mi egy vállalat $p$ ár melletti kínálati függvénye, ha már kibérelte az üzlethelyiséget?

d. Ha jelenleg 18 vállalat van a piacon (ők már béreltek üzlethelyiséget, más viszont nem tud még idén helyiséget bérelni és árusítást kezdeni), mennyi lesz az egyensúlyi ár?

e. Ha a piacon szabad a be- és kilépés, hosszú távú egyensúlyban hány euró lesz a paleo kóla ára, és hány vállalat lesz a piacon?

Eredmény Megoldás

7. feladat: A rózsák iránti keresleti függvény:

$$
D(p)=64-2 \cdot p
$$

Mint az közismert, a rózsatermesztéssel foglalkozó vállalatok változó költsége $\frac{y^{2}}{4}$. Ezen felül a piacon lévő vállalatoknak még 4 egység fix költsége van. Minden vállalat árelfogadó módon viselkedik, és a piacon szabad a be- és kilépés.

a. Mi egy piacon lévő vállalat $p$ ár melletti kínálati függvénye?

b. Mi egy vállalat $p$ ár melletti haszna? 
c. Hosszú távon mennyi lesz az ár és hány vállalat lesz a piacon?

A piac hosszú távú egyensúlyban van. A továbbra is erre számító vállalatok már ki is fizették a fix költséget, de ekkor az állam $t=16$ egységnyi mennyiségi adót vet ki a rózsákra.

d. Hogyan változik rövid távon a rózsák fogyasztói ára?

e. És hosszú távon?

Eredmény Megoldás

8. feladat: A közgazdasági tanulmányok iránti keresleti függvény:

$$
D(p)=200-\frac{p}{2} .
$$

Egy közgazdász 100 garast költ el, amíg megszerzi a diplomáját, ezután pedig y tanulmányt $40 \cdot y+y^{2}$ költséggel tud legyártani. Tegyük fel, hogy minden közgazdász árelfogadó, profitmaximalizáló, és a piacon szabad a be- és kilépés.

a. Mennyibe kerül egy közgazdasági tanulmány hosszú távon?

b. Hány közgazdász lesz a piacon hosszú távú egyensúlyban?

Az állam növeli a közgazdasági képzések tandíját 300 garassal.

c. Hogyan változik a tanulmányok ára rövid távon?

d. És hosszú távon?

Eredmény Megoldás

9. feladat: New Yorkban a taxifuvarok iránti keresleti függvény:

$$
D(p)=100-p .
$$

Mint az közismert, egy new yorki taxis fuvarokra vonatkozó költségfüggvénye:

$$
C(y)=y^{2} .
$$

Tegyük fel, hogy minden taxis árelfogadó, profitmaximalizáló. Az önkormányzat $F$ dollárért ad egy taxisengedélyt, taxizni csak ennek a birtokában lehet. 
a. Hány taxis lesz hosszú távon New Yorkban $F$ függvényében?

b. Milyen $F$ maximalizálja az önkormányzat összbevételét?

Eredmény Megoldás

10. feladat: Az 1900-as évek elején Japánban az amerikai iparcikkek iránti keresletet a

$$
D(p)=140-p
$$

függvény írja le. Az amerikai iparcikkek piacán szabad a belépés. A belépő vállalatok számára a termelés költségfüggvénye $C(y)=y^{2}+25$. Ezenfelül még a szállítás is költséges, ez termékenként 40 dollárral növeli a költségeket.

a. Hány dollárba kerül Japánban egy amerikai iparcikk hosszú távú egyensúlyban?

Az amerikai kormány fontolgatja a Panama-csatorna megépítését. Így rövidebb lenne az út a keleti parton lévő ipari központok és Japán között, a szállítási költségek 20 dollárra csökkennének.

b. Hogyan változna a csatorna megépülése után Japánban az amerikai iparcikkek ára rövid és hosszú távon?

c. Egy ilyen nagyszabású építkezés rendkívül költséges, az állam csak akkor vág bele, ha megéri. Mennyivel növelné a csatorna az amerikai termelői többletet rövid, és mennyivel hosszú távon?

Eredmény Megoldás 
TERMELÉS 
1. feladat: Családi vállalkozásban öltöztetett madárijesztőket gyártok. Jobban értek ahhoz, hogy fából elkészítsem a madárijesztő alakját, mint ahhoz, hogy felöltöztessem: naponta 15 alakot tudok készíteni, de csak hármat vagyok képes felöltöztetni. Unokahúgaim azonban jobban értenek a felruházáshoz. Mindannyian csak 1 alakot képesek kifaragni naponta, de Lusta Anna 9 öltözetet, Balkezes Borcsa 10 öltözetet, Nemtörôdöm Cili 11 öltözetet készít egy nap. Ha nem tudom elviselni, hogy csak lógjanak mellettem, és ragaszkodom ahhoz, hogy együtt dolgozzunk, ráadásul egész áldott nap, melyiket kérem meg a segítségre, ha naponta pontosan 10 öltöztetett madárijesztőt kell elő́llítanunk?

\section{Eredmény Megoldás}

2. feladat: Apacsföldön Öreg Bölény és Fiatal Szarvas ajándéktárgyakat - tomahawkokat - gyárt a turisták számára. Ha idejét kizárólag a tomahawk fejének megmunkálásával tölti, akkor Öreg Bölény egy óra alatt 10 fejet állít elő, ha csak nyelet farag, akkor 20 nyelet készít. Fiatal Szarvas egy óra alatt 8 fejet is kifarag, de a nyéllel nehezen boldogul, csak 5 nyelet tud készíteni. A tomahawknak egy feje és egy nyele van. Ha mindketten napi nyolc órát dolgoznak, és egy perccel sem többet, akkor maximum hány kész tomahawkot tudnak elóállítani naponta?

Eredmény Megoldás

3. feladat: Egy gazdaságban két ágazat van, a könnyúipar és a szolgáltató szektor. Mindkét ágazat tôkét $(K)$ és munkaerốt $(L)$ használ fel a termelés során. Jelöljük a könnyúiparban felhasznált tőke, illetve munka mennyiségét rendre $K_{1}$-gyel és $L_{1}$-gyel, a szolgáltató szektorban felhasznált tőke, illetve munka mennyiségét pedig rendre $K_{2}$ vel és $L_{2}$-vel. A termelési függvények rendre

$$
F_{1}\left(K_{1}, L_{1}\right)=\sqrt{K_{1} \cdot L_{1}}, \quad F_{2}\left(K_{2}, L_{2}\right)=4 \cdot \sqrt{K_{2} \cdot L_{2}},
$$

és összesen 400 egység tőke, valamint 100 egység munkaerő áll rendelkezésre.

a. Legfeljebb mekkora lehet a könnyûipar kibocsátása?

b. Legfeljebb mekkora lehet a szolgáltató szektor kibocsátása?

c. Jelöljük $q_{1}$-gyel a könnyúipar, $q_{2}$-vel a szolgáltató szektor kibocsátását. Adja meg adott $q_{1}$ kibocsátás mellett legfeljebb mekkora $q_{2}$ kibocsátás érhető el! (Ez egy függvény.)

Eredmény Megoldás 
4. feladat: Egy gazdaság kétfajta jószágot állít elő, jelöljük ezeket $x$-szel és $y$-nal. A termelési lehetőségek halmazát az

$$
f(x, y)=25 \cdot x^{2}+y^{2} \leq 2000
$$

egyenlőtlenség írja le. A kibocsátást a gazdaságban élő két fogyasztó között osztják szét, akiknek hasznosságfüggvényei rendre

$$
U_{A}\left(x_{A}, y_{A}\right)=4 \cdot \ln x_{A}+\ln y_{A}, \quad U_{B}\left(x_{B}, y_{B}\right)=4 \cdot \ln x_{B}+\ln y_{B} .
$$

a. Adja meg az

$$
(x, y)=(4,40), \quad\left(x_{A}, y_{A}, x_{B}, y_{B}\right)=(3,1,30,10)
$$

kibocsátást és fogyasztást leíró vektorok mellett a transzformációs határrátát és a fogyasztók helyettesítési határrátáit!

b. Adja meg a Pareto-hatékony fogyasztások halmazát!

Eredmény Megoldás

5. feladat: Robinson és Péntek ketten laknak egy szigeten. Csak halat és kókuszdiót fogyasztanak. Robinson és Péntek hasznosságfüggvényei

$$
U_{R}\left(H_{R}, K_{R}\right)=H_{R}^{2} \cdot K_{R}, \quad U_{P}\left(H_{P}, K_{P}\right)=H_{P}^{2} \cdot K_{P} .
$$

Robinson egy óra alatt 2 halat vagy 1 kókuszdiót termel (tekintsünk el attól, hogy szigorúan véve sem a halat, sem a kókuszdiót nem termelik), Péntek pedig 3 halat vagy 1 kókuszdiót. Robinson 9, Péntek 6 órát dolgozik.

a. Adja meg a termelési lehetôségek halmazát!

b. Adja meg a Pareto-hatékony fogyasztási lehetőségek halmazát!

Péntek nagyon belejön a halászatba, már óránként $\alpha$ halat tud fogni. (Ahol $\alpha>3$.)

c. Mennyi $\alpha$, ha egy Pareto-hatékony állapotban $\left(H_{R}, K_{R}\right)=(28,6)$ ?

\section{Eredmény Megoldás}

6. feladat: Robinson egy kis szigetközösség tagja. A szigeten csak halat és kókuszdiót termelnek, illetve fogyasztanak. Robinson 6 órát dolgozik, és egy óra alatt 1 halat vagy 2 kókuszdiót termel. A saját maga által megtermelt jószágok fölött szabadon rendelkezik, ezekkel kereskedhet a piacon, ahol egy hal ára $p$ kókuszdió árával egyenlő. Robinson hasznosságfüggvénye

$$
U_{R}\left(H_{R}, K_{R}\right)=\min \left(H_{R}, K_{R}\right) .
$$


a. Adja meg Robinson optimális kibocsátását $p$ függvényében!

b. Adja meg Robinson kókuszdióban mért jövedelmét $p$ függvényében!

c. Hány halat fogyaszt Robinson ( $p$ függvényében)?

Eredmény Megoldás

7. feladat: Egy zárt gazdaságban két fogyasztó, $A$ és $B$, illetve két jószág, $x$ és $y$ van. A fogyasztók hasznosságfüggvényei

$$
U_{A}\left(x_{A}, y_{A}\right)=a \cdot x_{A}+y_{A}, \quad U_{B}\left(x_{B}, y_{B}\right)=\min \left(x_{B}, y_{B}\right) .
$$

Az $i$ fogyasztó által $j$ jószágból termelt mennyiséget $q_{j}^{i}$-vel jelölve az $A$ fogyasztó termelési lehetőségeinek határhalmazát az

$$
q_{y}^{A}=\sqrt{36-2 \cdot\left(q_{x}^{A}\right)^{2}}
$$

egyenlet adja meg, $B$ fogyasztóét pedig az

$$
q_{y}^{B}=\sqrt{9-2 \cdot\left(q_{x}^{B}\right)^{2}}
$$

Mindketten a saját maguk által megtermelt jószágok fölött rendelkeznek.

a. Milyen árarány mellett maximalizálja $A$ profitját 4 egység $x$ és 2 egység $y$ jószág termelése?

b. Ha az a. pontban kiszámolt árarány mellett szabadon kereskedhet, mi lesz $B$ termelése és fogyasztása?

c. Ha az a. pontban kiszámolt árarány mellett kialakulhat versenyzői egyensúly, mit mondhatunk az ( $U_{A}$-ban szereplő) $a$ paraméterről?

\section{Eredmény Megoldás}

8. feladat: Egy Robinson Crusoe gazdaságban ketten vannak: Robinson és Péntek. Két jószágot fogyasztanak, halat és kókuszdiót, ezekre vonatkozó hasznosságfüggvényük mindkettójüknek szimmetrikus Cobb-Douglas-típusú. Robinson egy óra alatt 1 halat vagy 1 kókuszdiót termel, Péntek 2 halat vagy 1 kókuszdiót. Robinson naponta 2 órát dolgozik, míg Péntek 6-ot. Mindketten a saját maguk által megtermelt jószágok fölött rendelkeznek. Legyen a kókuszdió ármérce jószág, a hal ára pedig $p$. 
a. Mi Robinson profitmaximalizáló termelése $p$ függvényében?

b. Mi Péntek profitmaximalizáló termelése $p$ függvényében?

c. Adja meg a versenyzői egyensúlyi árarányt!

d. Hány halat fogyaszt Robinson versenyzői egyensúlyban?

Eredmény Megoldás

9. feladat: Robinson és Péntek ketten laknak egy szigeten. Csak halat és kókuszdiót fogyasztanak. Robinson hasznosságfüggvénye

$$
U_{R}\left(H_{R}, K_{R}\right)=2 \cdot H_{R}+5 \cdot K_{R}
$$

míg Péntekérôl csak azt tudjuk, hogy Cobb-Douglas-típusú. Robinson egy óra alatt 2 halat vagy 1 kókuszdiót termel, Péntek pedig 3 halat vagy 1 kókuszdiót. Robinson $a$ órát dolgozik, Péntek 8 órát, ételkészleteik nincsenek, és mindketten a saját maguk által megtermelt jószágok fölött rendelkeznek. Még azt is tudjuk, hogy versenyzői egyensúlyban Robinson fogyasztása 15 hal és 2 kókuszdió, Pénteké pedig 9 hal és 6 kókuszdió.

a. Hány órát dolgozik Robinson?

b. Mi az egyensúlyi árarány?

c. Mi Péntek hasznosságfüggvénye?

Eredmény Megoldás 
A MONOPÓLIUM 
1. feladat: Határmente lakói löttyöt isznak a katyvaszhoz, a közkedvelt remek nedű iránti inverz kereslet függvénye: $p=50-Y$. A faluban pontosan 2 cég termel löttyöt, mindkettő árelfogadó, profitmaximalizáló vállalkozás. Azért nem több, mert a korábbi korrupt polgármester pontosan ennyi engedély bocsátott ki. Egy termelő költségfüggvénye: $c(y)=6 y+y^{2}$. Az új polgármester - mivel az önkormányzatnak pénzre van szüksége - két lépést fontolgat. Az egyik értelmében 8 garas mennyiségi adót vet ki a lötty egy üvegére. A másik szerint bevonja az engedélyeket, és egy darab önkormányzati céget üzemeltet, ugyanolyan költségviszonyok mellett.

a. Ha az önkormányzat jövedelmét maximalizálja, melyik lépést választja? (A második esetben az önkormányzat jövedelme az önkormányzati cég profitja.)

b. A fogyasztók szempontjából melyik lépés a kedvezőbb, és miért?

Eredmény Megoldás

2. feladat: Madáretetôt jelenleg négy árelfogadó cég gyárt, azonos technológiával, teljesköltségfüggvényük $c(y)=2 y^{2}+6 y+12$, ahol $y$ az egy cég által legyártott madáretetôk darabszáma. A piaci keresleti függvény $Y=27-0.5 p$, ahol $Y$ az összes keresett etetô száma, $p$ egy etető ára. Ha a négy cég közül az elsô felvásárolhatná a többit, maximum mennyit lenne hajlandó fizetni értük?

\section{Eredmény Megoldás}

3. feladat: A herointartalmú üdítőitalok piacán a Hero Cola monopóliumként üzemel. A piacot a $D(p)=20-p$ keresleti függvény írja le. A Hero Cola költségfüggvénye: $C(y)=2 \cdot y+5$.

a. Mennyi a monopólium optimális termelése?

b. Mennyi ekkor a haszna?

c. Mi változik meg a fentiek közül, ha $C(y)=2 \cdot y+13$-ra módosul?

Eredmény Megoldás

4. feladat: Az elóző feladatot folytatva, a Hero Cola rájön, hogy inkább az árat fogja o megmondani, majd a leadott rendeléseket elégíti ki.

a. Mekkora a monopólium számára optimális ár? 
b. Mekkora ezen ár mellett a kereslet árrugalmassága?

c. Tegyük fel, hogy megváltozik a költségfüggvény $C(y)=5$-re, a monopólium emellett optimalizál. Mekkora lesz így a kereslet árrugalmassága?

Eredmény Megoldás

5. feladat: A legalább egy gigabites sávszélességú internet iránti keresleti függvény:

$$
D(p)=a-\frac{p}{2} .
$$

A piacon jelenleg monopólium a Google, költségfüggvénye: $C(y)=y^{2}$. Tudjuk még azt is, hogy a monopólium optimumban hat darab előfizetést ad el.

a. Mennyi $a$ ?

b. Mennyi a monopólium által okozott holtteherveszteség?

c. A kormány mennyiségi támogatással szeretné elérni, hogy a monopólium versenyzői szinten termeljen. Mennyi pénzt kell elköltenie?

\section{Eredmény Megoldás}

6. feladat: Egy vállalat szabadalmaztatja az "i" betût, mostantól csak ô árulhat olyan terméket, aminek a nevében ez a betû szerepel. A pizzák készítésével foglalkozó alrészlegének költségfüggvénye: $C(y)=y^{2}+a \cdot y+24$, és a pizza iránti keresleti függvény: $D(p)=40-2 \cdot p$. Optimumban a pizzakészító alrészleg a fedezeti pontban termel.

a. Mennyi $a$ ?

A ketchup árának emelkedése miatt csökken a pizza iránti kereslet, az új keresleti függvény: $D(p)=10-2 \cdot p$.

b. Mennyi most a monopólium profitmaximalizáló termelése?

Eredmény Megoldás 
MONOPOLISTA VISELKEDÉS 
1. feladat: A magyar labdarúgás iránt nem sokan érdeklődnek manapság, két csoportra osztható a rajongók hada: az önsanyargatókra és a rokonokra. Az önsanyargatóknak a következố mérkőzés jegye iránti keresleti függvénye $q_{\ddot{o}}=30-1.5 p_{\ddot{o}}$ alakú. (Az árak ezer forintban, a mennyiségek ezer főben értendők.) A rokonokét sajnos nem ismeri a szövetség főtitkára, akinek a feladata a jegyárak meghatározása. Megbízza ezért Önt, végezzen piackutatást a rokonok körében. A megbízás átadásakor panaszkodik, elmeséli, hogy irtózatos drága a meccs megrendezése, a szurkolók törnek-zúznak, kárt okoznak. Ha $Q$ szurkoló (ezer főben mérve) nézi meg a mérkőzést, akkor az általuk okozott határkár mértéke $M C(Q)=(Q-2)^{2}+2.25$. Ön lelkiismeretesen elvégzi a vállalt feladatot. Közli a főtitkárral, hogy a rokonok jegy iránti keresleti függvénye $q_{r}=10-0.5 p_{r}$ alakú. (Az árak itt is ezer forintban, a mennyiségek ezer fóben értendők.) A főtitkár el tudja dönteni, ki a rokon, illetve ki az önsanyargató, és optimálisan állapítja meg a jegyárakat (külön a rokonok, illetve az önsanyargatók számára).

a. Hány néző lesz a meccsen?

b. Mennyit fizetnek az önsanyargatók egy jegyért?

c. Mennyit fizetnek a rokonok egy jegyért?

Eredmény Megoldás

2. feladat: Galamdúcból van ám kereslet bőven: a postagalamb-tulajdonosok inverz keresleti függvénye $p_{p}=137-2 x_{p}$, a (szelídített) vadgalamb-tulajdonosoké $p_{v}=275-a x_{v}$. Mekkora az $a$ paraméter értéke, ha galamdúcot egy profitmaximalizáló, árdiszkrimináló monopolista gyárt csak, akinek konstans határköltsége 5 (fix költsége nincs), és a postagalambok számára értékesített galambdúcok száma hattal haladja meg a vadgalamdúcokét?

\section{Eredmény Megoldás}

3. feladat: A tűzálló mütyür az igazi sláger. Ez iránt két vevőkör is támaszt keresletet: a piromániások és a tűzoltók. A piromániások keresleti függvénye: $y_{p}=100-2 p_{p}$, a tűzoltóké $y_{t}=75-1.5 p_{t}$. A határköltség állandó: 6 garas, fix költség nincs. A helyi rendeletek szerint mindenkinek ugyanazon az áron kell adni a tűzálló mütyürt, de a gyártó monopolista pontosan tudja, a hatóság megvesztegethető. Sikeres vesztegetés esetén ezt a rendeletet hatályon kívül helyezik.

a. Hány mütyürt gyárt a monopolista, ha a rendelet érvényben van?

b. Mekkora a profija? 
c. Maximum mennyi pénzt hajlandó vesztegetésre áldozni, ha ezáltal lehetősége nyílik harmadfokú árdiszkriminációt alkalmazni?

\section{Eredmény Megoldás}

4. feladat: Ön egészen kiváló szivarvágókat gyárt és árul, terméke iránt két csoport érdeklődik, a szenvedélyes szivarozók, illetve azok, akik az összes szivart a legszívesebben felaprítanák. A szenvedélyes szivarozók keresleti függvénye: $D_{s z}(p)=40-2 p$, az aprítóké: $D_{a}(p)=20-p$, ahol $p$ a szivarvágó ára garasban. Sajnos Ön nem tudja megállapítani az aktuális vevőról, hogy melyik csoportba tartozik. Adna-e 1.5 garast egy olyan szakértőnek, aki képes erre, és ennyi pénzért el is árulná Önnek a dolog nyitját, ha a termelés és értékesítés együttes állandó határköltsége 15 garas?

\section{Eredmény Megoldás}

5. feladat: Az "A" Brand kóla iránti kereslet Kaliforniában $D_{1}\left(p_{1}\right)=44-2 \cdot p_{1}$, míg New York államban $D_{2}\left(p_{2}\right)=24-p_{2}$. Az "A" Brand kólát egyetlen cég forgalmazza, és $y$ egységnyi kólát $C(y)=y^{2}+4 \cdot y$ költséggel tud beszerezni. Melyik piacon mekkora lesz az ár, ha a cég maximalizálni szeretné a profitját?

\section{Eredmény Megoldás}

6. feladat: Egy $D(p)=60-2 \cdot p$ keresleti függvény által leírt piac kínálati oldalán egy profitmaximalizáló monopólium van, akinek költségfüggvénye $C(y)=y^{2}+7$.

a. Mennyit fog termelni a monopólium, ha nem alkalmazhat semmiféle árdiszkriminációt?

b. Mennyit fog termelni, ha használhat elsőfokú árdiszkriminációt?

c. Mennyivel növeli meg az elsőfokú árdiszkrimináció a monopólium profitját?

d. Mennyivel csökkenti a fogyasztói többletet?

\section{Eredmény Megoldás}

7. feladat: A Foci Múzeum kétféle jegyet árul: teljes árú jegyet és csak diákigazolvánnyal igénybe vehető diákjegyet. A teljes árú, illetve a diákjegy iránti keresleti függvények:

$$
D_{t}\left(p_{t}\right)=52-2 \cdot p_{t}, \quad D_{d}\left(p_{d}\right)=24-4 \cdot p_{d} .
$$

A múzeum költségei függetlenek a látogatók számától. 
a. Milyen árakkal tudja maximalizálni a múzeum a bevételét?

A hatóság kimondja, hogy az ilyen fajta diszkrimináció egy jogállamban elfogadhatatlan, ezért a múzeum köteles azonos áron beengedni minden látogatóját.

b. Mi lesz most a profitmaximalizáló ár?

c. Melyik esetben volt nagyobb a fogyasztói többlet?

d. Melyik esetben volt nagyobb a jólét?

Eredmény Megoldás

8. feladat: A Malátta? sörfőzde kézmúves sörét saját szegedi kocsmájában és egy nyugat-magyarországi fesztiválon értékesíti. A két piacon persze nem ugyanazzal a kereslettel szembesül, és mivel a fesztivállátogatók nem fognak egy sörért Szegedre utazni, harmadfokú árdiszkriminációt alkalmazhat. A fesztiválon a keresleti függvény:

$$
D_{F}\left(p_{F}\right)=\alpha \cdot p_{F}^{\beta},
$$

ahol $\alpha$ valamilyen pozitív szám és $\beta=-1$.2. Ha a sörfőzde a fesztiválon $y_{F}$, a kocsmában pedig $y_{K}$ sört ad el, akkor $C\left(y_{F}+y_{K}\right)$ költséggel szembesül. Tudjuk, hogy profitmaximumban a kocsmában 600 forintba kerül egy üveg sör, emellett a kocsmai kereslet árrugalmasságának abszolútértéke $-4 / 3$, és mind a fesztiválon, mind a kocsmában adnak el sört.

a. Hány forint egy sör a fesztiválon optimumban? (A profitmaximalizáló sörfőzde optimumában, nem az Önében.)

b. Mennyibe kerülne optimumban a sörfőzdének még egy (marginális) sört készítenie?

\section{Eredmény Megoldás}

9. feladat: A Tosche lakóparkban eddig nem volt uszoda, de most végre nyílt egy. Ezt csak a helyiek használhatják, és ők is csak akkor, ha rendelkeznek a névre szóló, át nem ruházható éves bérlettel. A bérlet iránti inverz keresleti függvény $p(y)=80-2 \cdot y$, ahol $y$ az eladott bérletek mennyisége. (Összesen 40 egységnyi lakó van, ennyi bérletet lehetne ingyen elosztogatni.) Az uszodát üzemeltető vállalkozás a szerződés részeként rengeteg adatot kapott a lakóparktól. Ezekból meg tudja állapítani minden egyes lakó rezervációs árát. A vállalkozás cserébe megígérte a lakóparknak, hogy ha egy lakónak 30 vagy annál kisebb a rezervációs ára, akkor az ingyen kap bérletet. A többi lakóval 
szemben a profitmaximalizáló uszoda elsőfokú árdiszkriminációt alkalmaz. Az uszoda költségfüggvénye $C(y)=y^{2} / 4+25$.

a. Hány bérletet ad ingyen az uszoda, és hányat ad el pénzért?

b. Mennyi az uszoda haszna?

c. Mekkora ezen a piacon a holtteherveszteség?

d. Hogyan változnak meg a fenti kérdésre adott válaszai, amennyiben az inverz keresleti függvény:

$$
p(y)=150-2 \cdot y ?
$$

(Ekkor lakóból is 75 egységnyi van.)

Eredmény Megoldás 
TÉNYEZŐPIACOK 
1. feladat: A piacon igen kelendő kelendelőt egy cég, a profitmaximalizáló KELEKótya Rt. gyártja. A kelendelő iránti kereslet függvénye: $y=60-0.5 p$, ahol $y$ a termelt kelendelők száma, $p$ a méltán kedvelt jószág ára. A termelési függvény $y=K^{1 / 2} L^{1 / 2}$, ahol $K$ a termelésben felhasznált tôke, $L$ a termelésben felhasznált munka mennyisége. A KELE-Kótya Rt. telephelye Kelenalföldön van, ebben a községben a KELE-Kótya $R t$. az egyetlen munkáltató. A kelenalföldi munkások inverz munkakínálati függvénye: $w=14+2 L$, ahol a $w$ a munkabér. Hány kelendelôt gyárt a KELE-Kótya Rt., ha az optimumban 9 munkást foglalkoztat?

Eredmény Megoldás

2. feladat: Az ütésálló mütyür piacán a keresleti függvény: $Y=52-0.5 p$. Az ütésálló mütyür gyártásához kizárólag szakképzett munkások kellenek, a profitmaximalizáló, ezen az ütésállómütyür-piacon monopolista cég ezeket a munkásokat egy versenyzôi munkapiacról szerződteti $w$ garas bérért. Egy munkás pontosan 5 mütyürt gyárt egy nap alatt.

a. Mekkora ez a $w$ bér, ha az optimumban a munkás határtermékének a piaci áron vett értéke ezt pontosan 250 garassal haladja meg?

b. Mekkora a monopolista profitja, ha más költsége nincs is?

\section{Eredmény Megoldás}

3. feladat: Egy vállalat termelési függvénye $Y(L)=120 L-0.1 L^{2}$, ahol $L$ a felhasznált munka mennyisége. Termékét tökéletes versenypiacon értékesíti, ahol az egyensúlyi ár 10. A vállalat a munkának egyetlen felhasználója, a munkakínálati függvény $L(w)=0.25 w-50$. Mennyi a felhasznált munka mennyisége és a bér?

\section{Eredmény Megoldás}

4. feladat: A Bölény és Szarvas Betéti Társaság a tomahawkok monopolista gyártója, tulajdonosai azonban már unják a munkát. Ezért elhatározzák, hogy munkanélküli törzstársaikat fogják foglalkoztatni. (Ők sehol máshol nem kapnak munkát, mert a törzsnél nincs más munkalehetőség.) Ehhez engedélyt kérnek Merész Sastól, a törzsfőnöktől, aki - bizonyos feltételek mellett - kész rábólintani kérelmükre. E feltételek szerint a $B t$-nek két lehetősége van: vagy annyi munkást foglalkoztatnak, ahányat csak akarnak, egyenként $13 \mathrm{~kg}$ medvehúsért, vagy a $w$ bért (medvehúskilogrammban) maguk állapíthatják meg, de akkor a közösbe kell befizetniük pótlólagosan és egy összegben 16 kg medvehúst. A tomahawkok előállításához a munkán $(L)$ kívül kitartásra $(K)$ is szükség van, ebből most éppen 16 egység áll rendelkezésre, és remény sincs arra, hogy ennél többet beszerezzenek. A termelési függvény $T=(K L)^{1 / 2}$ alakú, 
ahol $T$ az előállított tomahawkok mennyisége. A tomahawkok iránti inverz keresleti függvény: $p=29-T$, ahol $p$ a tomahawk ára medvehúskilogrammban, a törzstagok inverz munkakínálati függvénye $w=5+L$. Melyik lehetôséget választja a Bölény és Szarvas $B t$, ha a profitját szeretné maximalizálni?

Eredmény Megoldás

5. feladat: Egy gyógyszeripari cég rendelkezik az öregedés elleni szer világszabadalmával. A csodaszer iránti keresletet a

$$
D(p)=100-p
$$

függvény írja le. A titkos előállítási technika egyetlen alapanyaga egy ritka brómizotóp. A cég kémikusai $x$ gramm izotópból $2 \cdot \sqrt{x}$ gramm öregedés elleni szert tudnak előállítani.

a. Mi a gyógyszeripari cég (brómizotópra vonatkozó) határtermék-bevétele?

b. Mi a gyógyszeripari cég brómizotóp iránti tényezőkeresleti függvénye? (Csak az öregedés elleni szer előállítása során használják ezt az izotópot.)

Eredmény Megoldás

6. feladat: Egy vállalat termelési függvénye:

$$
f(x)=\sqrt{x} .
$$

Az $x$ inputtényezőt csak a vállalat vásárolja. A tényező kínálati függvénye:

$$
S\left(p_{x}\right)=p_{x}-2
$$

A készterméket egy kompetitív piacon, $p$ ár mellett lehet értékesíteni. Mekkora a $p$ ár, ha tudjuk, hogy optimumban a tényezókínálati görbe tényezőár-rugalmassága $\frac{3}{2}$ ?

\section{Eredmény Megoldás}

7. feladat: Egy vidéken minden föld a retektermesztő gazdaságé, aki földmúvesként szeretne dolgozni, csak itt teheti. A retek piaca nagyon kompetitív, 4 euró/kg vagy alacsonyabb áron bármekkora mennyiséget el lehet adni, ennél drágábban semennyit. Egy földmúves $100 \mathrm{~kg}$ retket tud termeszteni, és a munkabéren kívül nincs költség. A környékbeli földmúvesek munkakínálati függvénye:

$$
S(w)=\frac{w}{100} .
$$


a. Ilyen bér mellett hány földmúvest alkalmaz a monopszónia?

b. Mennyi lesz a munkabér, ha a monopszónia maximalizálja a profitját?

\section{Eredmény Megoldás}

8. feladat: Nyugat-Piréziában a Nyugat-Piréziai Pékség $(N y P P)$ a pékek egyetlen foglalkoztatója, és kenyeret is csak tőlük lehet vásárolni. A termelési függvényük:

$$
f(L)=\sqrt{L},
$$

és az előállítás során egyéb költség nincs. A munkakínálati görbe:

$$
L(w)=w^{2} .
$$

A kenyér iránti keresleti függvény:

$$
D(p)=\frac{9}{2}-\frac{1}{24} \cdot p .
$$

Milyen munkabér maximalizálja a $N y P P$ profitját?

Eredmény Megoldás 
OLIGOPÓLIUM 
1. feladat: Jól ismerjük már a gombfocikapu-, illetve gombfocicsapat-piac rejtelmeit, de a gombfocilabda piacának tulajdonságait csak mostanában kezdtük tanulmányozni. Ezen a piacon az inverz keresleti függvény: $p=16-Y$. A labdákat két profitmaximalizáló cég gyártja, az elsô bejelenti, mennyi labdát dob a piacra, a második ehhez alkalmazkodik. Az első cég költségfüggvénye: $c_{1}\left(y_{1}\right)=y_{1}^{2}$, a másodiké: $c_{2}\left(y_{2}\right)=2 y_{2}$.

a. Mennyit termel a vezérlő és mennyit a követő vállalat?

A két cég kartellmegállapodást köt, és meg is tartja.

b. Mennyivel változik az előző esetbeli vezérlő termelése?

\section{Eredmény Megoldás}

2. feladat: A mennyasszonyi fátylak piacán két profitmaximalizáló cég (a Csipke Bt. és a Rózsika Kft.) baráti Cournot-versenyt folytat. A Csipke Bt. tulajdonosa unja a helyzetet, de szerencséjére két új lehetőség közül választhat. Vagy felajánlja a Rózsika Kft.nek, hogy tömörüljenek kartellba, és a profiton fele-fele arányban osztozzanak, vagy elfogadja Hófehérke javaslatát. Hófehérke, aki egy önálló feltaláló mérnök, ugyanis rájött, miként kell a fátyolgyártás költségeit pontosan a felére csökkenteni, és ezt a tudását 70 aranytallérért boldogan megosztaná a Csipke Bt.-vel. (Ekkor a két cég továbbra is Cournot-módon viselkedne.) A fátylak iránti kereslet függvénye: $y=90-p$, ahol $y$ a fátylak mennyisége, és $p$ a fátylak ára. Jelenleg mind a két cég 10 tallér konstans határköltség mellett termel, fix költségük nincs.

a. Mennyit termelne a kartell?

b. Mennyit termelne a Csipke Bt., ha elfogadja Hófehérke ajánlatát?

c. Vajon Hófehérke megkapja-e a 70 aranytallért?

Eredmény Megoldás

3. feladat: Apacsföldön a tomahawkok piacán az inverz keresleti függvény: $p=20-Y$. A tomahawkokat két profitmaximalizáló cég gyártja, az elsô - az Öreg Bölény Bt. - bejelenti, mennyi tomahawkot dob a piacra, a második - a Fiatal Szarvas Bt. - ehhez alkalmazkodik. Az első cég költségfüggvénye: $c_{1}\left(y_{1}\right)=y_{1}^{2}$, a másodiké: $c_{2}\left(y_{2}\right)=a y_{2}$. ( $Y=y_{1}+y_{2}$ nyilván.) Mekkora a Fiatal Szarvas Bt. termelése, ha az Öreg Bölény Bt. (amennyiben maximalizálja saját profitját) 4 tomahawkot dob a piacra? (Konkrét szám a megoldás!)

\section{Eredmény Megoldás}


4. feladat: A jakszőrme piacán az inverz keresleti függvény

$$
p(q)=50-q .
$$

Jakot csak ketten tenyésztenek, Mohandas és Javaharlal. Mindkettőjük határköltsége állandó, 8, ez köztudott tudás. Javaharlal profitját maximalizálja, míg Mohandas spirituális szempontok alapján határozza meg kibocsátását. Mindketten az általuk termelt mennyiségrôl döntenek, mégpedig egyszerre. A piacon az összkibocsátásnak megfelelően alakul az ár.

a. Javaharlal megtudja, hogy Mohandas valamilyen okból kifolyólag 10 jakszőrmét fog eladni. Hány jakszőrme eladásával tudja saját profitját maximalizálni?

Még mielőtt Javaharlal belefogna a termelésbe, az ipari kémek jelentik, hogy Mohandas megnövelte termelését, és 20 jakszőrmét fog eladni!

b. Mennyi így Javaharlal profitmaximalizáló kibocsátása?

c. Tulajdonképpen mi Javaharlal (a Mohandas termelésére vonatkozó) reakciófüggvénye?

Eredmény Megoldás

5. feladat: Az üveggolyók piacán a keresleti függvény:

$$
D(p)=60-2 \cdot p .
$$

Üveggolyót két vállalat gyárt. Mindkét vállalat határköltsége állandó, 2 fabatka. A vállalatok mennyiségi döntést hoznak.

a. Az első vállalat úgy értesül, hogy a második vállalat 20 üveggolyót fog gyártani. Mennyi üveggolyó gyártásával tudja saját profitját maximalizálni?

b. Mi az elsố vállalat második vállalat kibocsátására vonatkozó reakciófüggvénye?

c. A második vállalat megtudja, hogy az elsô vállalat azt hiszi, hogy ők 20 üveggolyót fognak gyártani, és erre alapozva határozza meg saját kibocsátását. Mennyi ekkor az ô profitmaximalizáló termelésük?

d. Ha az elsố vállalat olyan balek lenne, hogy bemondásra elhinné a második vállalatnak, hogy az mennyit fog termelni, mit mondana neki a második vállalat?

Eredmény Megoldás 
6. feladat: A közepesen okos telefonok piacán a keresleti függvény:

$$
D(p)=100-p .
$$

A piac kínálati oldalán két vállalat van. Mindkettő állandó, 40 dolláros határköltséggel termel. A vállalatok az általuk gyártott telefonok mennyiségéról döntenek. Az egyik vállalat azonban előbb hozza meg a döntését. A második vállalat így döntése meghozatalakor már tudja, hogy az elsô vállalat hogyan döntött. Hány dollár lesz az egyensúlyi ár?

Eredmény Megoldás

7. feladat: A fapapucs piacán a keresleti függvény:

$$
D(p)=100-p .
$$

Fapapucsot két vállalat gyárt. Költségfüggvényeik ugyanolyanok, konkrétan:

$$
C_{1}(y)=C_{2}(y)=40 \cdot y \text {. }
$$

(Ez csak függvények leírása, természetesen lehet különböző a kibocsátásuk.) Mindketten a saját kibocsátásukról döntenek, mégpedig egyszerre.

a. Mi az első vállalat második vállalat kibocsátására vonatkozó reakciófüggvénye?

b. Mi a második vállalat első vállalat kibocsátására vonatkozó reakciófüggvénye?

c. Milyen $\left(y_{1}, y_{2}\right)$ kibocsátáspárra igaz az, hogy mindegyik vállalat maximalizálta profitját a másik vállalat adott kibocsátási szintje mellett?

\section{Eredmény Megoldás}

8. feladat: Egy téren két fagyizó van. Az itt megforduló emberek aggregált fagyikeresleti függvénye:

$$
D(p)=400-2 \cdot p .
$$

A két fagyizó egyaránt 150-150 forintos határköltséggel tud fagyit készíteni. Mindketten arról döntenek, hogy milyen áron kínálják a fagyit. Ez minőségileg mindkét helyen ugyanolyan, ezért az emberek mind oda mennek, ahol a legolcsóbb a fagyi. Ha éppen ugyanolyan árat határoznak meg, akkor az emberek fele az egyik, fele a másik fagyizóban vásárol. Ha az első fagyizó $p_{1}=200$ forintos áron árulja a fagyiját, mekkora lesz a második fagyizó profitja, ha 
a. $p_{2}=300$ ?

b. $p_{2}=100$ ?

c. $p_{2}=170$ ?

De az első fagyizó nem biztos, hogy 200 forintos árat szab meg. Igazából csak annyit tudunk, hogy mindkét cukrászda egyszerre dönt az árról.

d. Egyensúlyban melyik fagyizó hány forintos árat határoz meg?

Eredmény Megoldás

9. feladat: Patvarrögfalván az állami vállalat és egy magánvállalat szolgáltat áramot. Az áram $(\mathrm{kWh})$ iránti a keresleti függvény:

$$
D(p)=21-p .
$$

A piaci mechanizmus a következő: először a profitmaximalizáló állami vállalat meghatározza az árat. A profitmaximalizáló magánvállalat ezt megfigyeli, és eldönti, hogy ilyen ár mellett mennyi áramot szeretne eladni. Ha a magánvállalat nem elégíti ki a teljes keresletet, akkor az állami vállalat is adhat el áramot. Az állami és a magánvállalat költségfüggvényei rendre:

$$
C_{1}\left(y_{1}\right)=6 \cdot y_{1}, \quad C_{2}\left(y_{2}\right)=y_{2}^{2} .
$$

Milyen árat határozzon meg az állami vállalat?

Eredmény Megoldás

10. feladat: Egy piacon a keresleti függény:

$$
D(p)=a-3 \cdot p,
$$

ahol $a>0$ egy paraméter. A piac kínálati oldala egy Cournot-duopóliumból áll. A vállalatok költségfüggvénye azonos,

$$
C(y)=y^{2}+25 .
$$

Mennyi az a paraméter értéke, ha Cournot-egyensúlyban az egyik vállalat profitja 275 ?

Eredmény Megoldás 
11. feladat: Egy piacon a keresleti függény:

$$
D(p)=280-p .
$$

A piac kínálati oldalán egy Cournot-duopólium van. Mindkét vállalat költségfüggvénye:

$$
C_{i}\left(y_{i}\right)=y_{i}^{2}+20 .
$$

Az elsô vállalat egyszeri befektetéssel elérheti, hogy a piac olyan Stackelbergduopóliummá változzon, ahol övé a vezetői szerep. Mennyit hajlandó költeni erre a befektetésre?

Eredmény Megoldás

12. feladat: Egy piacon a keresleti függény:

$$
D(p)=a-p,
$$

ahol $a>0$ egy paraméter. A piac kínálati oldala egy Cournot-oligopólium. Minden vállalat állandó $c$ nagyságú határköltséggel termel, fix költség nincs. Legalább hány vállalat van a piacon, ha egy oligopolista Cournot-egyensúlyi profitja kevesebb mint tizede az összes vállalatot tartalmazó kartell profitjának?

Eredmény Megoldás 
KÜLSŐ GAZDASÁGI HATÁSOK 
1. feladat: A ketyere piaci ára 110 garas, a falunkban egy kis ketyerét gyártó, árelfogadó üzem múködik, költségfüggvénye: $C(k)=2 k^{2}+10 k$. Szomszédjában, a mütyürgyárban nem örülnek a ketyere konjunktúrájának, hiszen a mütyür előállítási költsége negatívan függ az előállított ketyerék által keltett zajtól. Egy mütyür ára 180 garas, ezt a gyár elfogadja, a mütyür költségfüggvénye: $C(m)=m^{2}+20 m+c k$, ahol $c$ egy konstans paraméter.

a. Mekkora a társadalmilag optimális ketyeretermelés ( $c$ függvényében)?

b. Mekkora a befizetendő összes Pigou-adó ( $c$ függvényében)?

c. Mennyivel változik a mütyürtermelés, ha az állam ténylegesen bevezeti a Pigou-adót?

Eredmény Megoldás

2. feladat: A Paradicsom-tó nemcsak igazi motorcsónak-, hanem a horgászparadicsom is. A motorcsónakosok hasznossági függvénye:

$$
U_{m}=m_{m}+12 c-c^{2}-2 h,
$$

ahol $m_{m}$ a jövedelmük, $c$ az általuk a tavon töltött idő, $h$ a horgászok által a tavon töltött idő (órában mérve). A horgászok hasznossági függvénye pedig:

$$
U_{h}=m_{h}+36 h-h^{2}-2 c .
$$

a. Ha senkit nem érdekel, hogy zavarja a másikat, mennyi időt töltenek a tavon a motorcsónakosok, és mennyit a horgászok?

b. Ha elhatározzák, hogy ezentúl csak annyi időt töltenek a tavon, hogy az együttes összes hasznosságuk maximális legyen, akkor minimum mennyi ideig lesz nyugtuk a halaknak? (Másképpen: maximálisan mennyi időt motorcsónakoznak és horgásznak összesen?)

Eredmény Megoldás

3. feladat: Az Apacsfölddel szomszédos két törzsi területen, a Navajo Tónál és a Komancs Kanyonban egész más világ uralkodik. E két helyen már az aranyrög a fizetési eszköz, mindent abban mérnek. A navajók a turisták szórakoztatására vadászatokat ( $v)$ szerveznek, egy vadászatot 100 aranyrögért tudnak eladni, de a szervezésnek komoly költsége van: ha $v$ vadászatot terveznek, akkor a költség $v^{2}$ : Ezen felül költségeiket jelentősen befolyásolja, hogy a komancsok törzsi csatákat $(c s)$ mutatnak be a turistáknak. 
Ezek értékesítési ára szintén 100 aranyrög, és $c s$ csata költsége $c s^{2}$, emellett minden egyes komancs csata 80 aranyröggel növeli a navajók költségeit. A navajók panaszkodnak is rendesen, hiszen tevékenységük így erősen veszteséges.

a. Mekkora ez a veszteség?

A navajóknak több lehetőségük van e veszteségek elkerülésére: vagy abbahagyják a turisták szórakoztatását, ekkor profitjuk zérus, vagy felvásárolják a komancsok vállalkozását, azaz kifizetik nekik azt a profitot, amit a csaták bemutatásából azok megszerezhetnének. Ekkor vagy magukra vállalják a csaták bemutatását is, vagy egyáltalán nem mutatnak be csatákat, csak vadászatokat szerveznek.

b. Melyik lehetőséget választják a navajók, ha profitjukat maximalizálják?

Eredmény Megoldás

4. feladat: Egy kis faluban tíz háztartás és egy szénerőmú van. A szénerômú a megtermelt villamos energia egységét 10 petákért tudja eladni, és $y$ egység energiát $y^{2}+6 \cdot y+5$ költséggel tud megtermelni. A folyamat melléktermékeként $y$ egység hő keletkezik, ami hasznos, mert a faluban hideg van, és egy hőegység kielégíti egy ház teljes fútésigényét. Ha egy háztartás nem kap hőt az erőmútől, 8 petákba kerül egyéb módon befüteni. A hőegységeket nem lehet eladni, csak ingyen elajándékozni.

a. Hány egység energiát fog termelni az önző hőerőmű?

b. Mekkora lenne a társadalmilag optimális energiatermelés?

c. A villamos energia árának mekkora mennyiségi támogatásával lehet elérni a társadalmilag optimális termelést?

d. Ha az erőmú versenyzői piacon árulná a hőegységeket, mennyi lenne azok ára?

Az önkormányzat kötelezi az erőmúvet, hogy minden arra igényt tartó háztartásnak adjon egy hőegységet. Ennek ellenére a hőegységek versenyzői piaca megmarad.

e. Hány háztól vásárolja vissza az erőmű a hőegységeket? (Vagyis fizet azért, hogy ne jelentsenek be igényt.)

Eredmény Megoldás 
5. feladat: Egy folyó mentén egy acélgyár és lejjebb egy halászat található. Az acélmúvek költségfüggvénye:

$$
C_{s}(s, x)=s^{2}-s \cdot x+x^{2},
$$

ahol $s$ a termelt acél mennyisége, $x$ pedig az általa a folyóba öntött környezetszennyező hulladék mennyisége. A halásztársaság költségfüggvénye:

$$
C_{f}(f, x)=f^{2}+f \cdot x .
$$

Környezetvédelmi előírások hiányában az acélmúvek annyit szennyez, amennyit csak jól esik. Az acél ára 24, a halé 16.

a. Mindkét vállalat a saját hasznát maximalizálja. Hány halat fognak a halászok?

b. Ha az acélmû szennyezése társadalmilag optimális lenne, mennyi acélt termelnének?

c. Ha a szennyezési jogoknak versenyzői piaca lenne, és kezdetben a jogok a halásztársaságnál lennének, mennyi lenne a halásztársaság profitja?

Eredmény Megoldás

6. feladat: Ha $x$ taxi van New Yorkban, egy taxi $100-x$ dollár bevételre tesz szert. ${ }^{1}$ Egy taxi beszerzési és üzemeltetési költsége 10 dollár, egyéb költség vagy alternatíva költség nincs. A piacon szabad a belépés.

a. Hány taxi lesz New Yorkban?

A taxis szakszervezet elintézi, hogy csak engedéllyel lehessen New Yorkban taxit vezetni. Ôk döntik el, hogy ki kaphat engedélyt. A szakszervezet a taxisok összhasznát akarja maximalizálni.

b. Hány engedélyt ad ki a szakszervezet?

c. Mennyit ér egy taxis engedély?

\footnotetext{
${ }^{1}$ Nem azért, mert a nagyobb kínálat lenyomja az árakat, hanem mert a sok autó miatt többet kell dugóban állni. Az árverseny nem külsô gazdasági hatás lenne, az egy normális gazdasági jelenség.
} 
d. Az engedélyek témáját félretéve, tegyük fel, hogy egy nem egyensúlyi pillanatban pontosan 20 taxi van New Yorkban. (Nem egyensúlyi, hiszen ha nem engedélyhez kötött a belépés, ekkor megéri belépni újabb taxisoknak.) Pareto-hatékony ez az állapot?

Eredmény Megoldás

7. feladat: A Kaveri folyó forrása Indiában, Karnataka államban található. A folyó a szomszédos Tamil Nadu államon áthaladva éri el az óceánt. Mindkét állam nagy mennyiségben használ fel vizet öntözéshez. A mezőgazdasági termények egységét mindketten 28 crore rúpiáért tudják értékesíteni, de minden egységnyi termény előállításához egy $\mathrm{km}^{3}$ vízre van szükség. A termelés során semmi más nem szükséges, de az öntözés költsége a Kaveri vízhozamától függ. Ha egy államba $h \mathrm{~km}^{3} / e ́ v$ víz áramlik be, akkor $x_{i} \mathrm{~km}^{3}$ víz szivattyúzásának a költsége $(25-h) \cdot x_{i}+x_{i}^{2}$ crore rúpia. A Kaveri vízhozama Karnataka államban $21 \mathrm{~km}^{3} /$ /év, és mivel itt van a folyó forrása, a Tamil Nadu államba érkező vízhozam annyival kevesebb, amennyit a karnatakaiak kivonnak. A tamilok által kivont vízmennyiségnek semmilyen hatása nincs a karnatakai mezőgazdaságra.

a. Ha mindenki annyi vizet használ fel, amennyit akar, és az államok nem kötnek egyezséget, mennyi vizet használ fel Karnataka, és mennyit Tamil Nadu?

b. Mennyi vizet használjon fel Karnataka, hogy az összprofit maximális legyen?

c. Ha Karnata vízfelhasználáshoz való jogát az a. pontbeli szinten rögzítenénk, de Tamil Nadu további csökkentést vásárolhat tőle, mi lenne egy $\mathrm{km}^{3}$ vízfelhasználási jog versenyzői ára?

Eredmény Megoldás 
KÖZJAVAK 
1. feladat: Az utcánkban közvilágítást létesítünk. Egy egységnyi (bármiben mérjük is) közvilágítás létesítésének költsége $p$ garas. Az én közvilágításra ( $q$ ) és egyéb javakra költhető jövedelemre $(m)$ vonatkozó hasznossági függvényem:

$$
U(q, m)=20 q^{1 / 2}+m .
$$

a. Mekkora a $p$ költség, ha én az összes jövedelmem 42 garas, és 16 egység közvilágítást finanszíroznék a szívem szerint?

Az utcánkban mások is laknak, a többiek hasznossági függvénye (egyénenként):

$$
U(q, m)=10 q^{1 / 2}+m .
$$

Jövedelmük megegyezik az enyémmel.

b. Hány egység közvilágítást dobunk össze?

c. Hányan laknak az utcában, ha a közvilágítás Pareto-hatékony szintje 468 egységgel haladja meg az összedobott nagyságot?

Eredmény Megoldás

2. feladat: Zsáknyi Méreg a wapimi törzs nagy varázslója. Varázslatait a törzs egésze számára nyújtja (a varázslat közjószág). Egy varázslatot 60 bölénybőrért állít elő. A törzs tagjait két csoportba sorolhatjuk: Méregzsák, a törzsfőnök támogatói és ellenzői egyaránt igényt tartanak a varázslatokra. A támogató 10 harcos hasznossági függvénye: $U_{t}(v, b)=-v^{2}+6 v+b$, ahol $v$ a varázslatok száma, $b$ a bölénybőrök száma. A törzsfőnök ellenzékének számító 20 harcos hasznossági függvénye: $U_{e}(v, b)=-2 v^{2}+30 v+b$. Egy indián rendelkezésére álló bölénybőrök száma korlátlan.

a. Hány varázslat lenne optimális a törzs számára?

b. Hány varázslatot vesz a törzs Zsáknyi Méregtől, ha a harcosok önként, saját érdeküket figyelembe véve adják össze az ellenértéket?

Eredmény Megoldás

3. feladat: Egy 20 lakosú faluban minden polgár hasznossági függvénye:

$$
U_{i}\left(x_{i}, y\right)=x_{i}+20 \cdot \sqrt{y},
$$

ahol $x_{i}$ az $i$-edik polgár által birtokolt pénz, $y$ pedig a mújégpálya területe $m^{2}$-ben mérve. A mújégpálya négyzetméterenkénti építési költsége 2. Minden lakos nagyon gazdag. 
a. Mekkora lesz a legnagyobb mújégpálya, ha mindenki magának épít egyet?

b. Mekkora egy közös mújégpálya Pareto-hatékony mérete?

Eredmény Megoldás

4. feladat: Egy nyolctagú társaság vacsorázni megy. A társaság minden tagjának hasznossági függvénye:

$$
U(x, y)=x+\ln y,
$$

ahol $x$ a tag által birtokolt pénz, $y$ pedig az általa fogyasztott étel ára. Ebben a feladatban is mindenki gazdag.

a. Mennyit fizet a társaság, ha mindenki a saját fogyasztását fizeti?

b. Mennyit fizetnek, ha előre megbeszélik, hogy mindenki annyit eszik, amennyit akar, és a számlát a végén 8 egyenlő részre osztják?

c. Melyik szituációban nagyobb a vacsorázók hasznossága?

Eredmény Megoldás

5. feladat: Auna Pala szigetén 100 ember lakik. Az egyes lakosok hasznossági függvénye:

$$
U_{i}\left(g, x_{i}\right)=\sqrt{g}+x_{i},
$$

ahol $g$ a közjószágra (egészségügy, infrastruktúra stb.) fordított állami kiadás, $x_{i}$ pedig a lakos által magánjószágra költött pénz. Minden lakosnak 250 auno sol vagyona van.

a. Mekkora a társadalmilag optimális állami kiadás?

Az állam úgy tervezi, hogy a fenti kiadáshoz szükséges bevételt adó formájában szedi be, mégpedig egyenlően osztja szét az adóterhet a 100 állampolgár között. Viszont a kormány fél a népszerúségvesztéstől, ezért ha valaki nem fizeti be az adót, akkor nem büntetik meg.

b. Mennyi adóbevétel folyik be egyensúlyban? 
c. Tegyük fel, hogy Ön is aunai polgár, és jelenleg nem egyáltalán nem fizet adót. Ha dönthetne úgy, hogy muszáj legyen mindenkinek befizetni az adót (megszúnik az adóelkerülés lehetősége), akkor élne ezzel a lehetôséggel?

Eredmény Megoldás 
II. rész

Eredmények 
INTERTEMPORÁLIS VÁLASZTÁSOK 


\section{1. feladat:}

25600 .

Vissza a feladathoz

\section{2. feladat:}

20.

Vissza a feladathoz

\section{3. feladat:}

$$
a=12 \text {. }
$$

Vissza a feladathoz

\section{4. feladat:}

a.

$$
x_{0}=480
$$

b. Az idei fogyasztása - nyeremény esetén -

$$
x_{0}^{\prime}-x_{0}=240
$$

egységgel nő.

Vissza a feladathoz

\section{5. feladat:}

a.

$$
m_{2}=704
$$

b.

$$
X=2728 \text {. }
$$


c.

$$
x_{1}^{*}=\frac{600+\frac{704+2728}{1.1}}{2}=1860 .
$$

Vissza a feladathoz

6. feladat: Abraxas fogyasztása

$$
g_{2}-g_{1}=110-15=85
$$

egység gitárzenével nő.

Vissza a feladathoz

7. feladat: Kronosz jövőre 66 garast fog fogyasztásra költeni.

Vissza a feladathoz

\section{8. feladat:}

a. Idén legfeljebb 350 kiló brokkolit vehetünk.

b. Jövőre legfeljebb 378 kiló brokkolit vehetünk.

c. A reálkamatláb $8 \%$.

d. Az optimális fogyasztás

$$
x_{1}=200 x_{2}=162 \text {. }
$$

Vissza a feladathoz

\section{9. feladat:}

a. 50\%-os kamatláb melett. 
b. $\quad r$ kamatláb mellett

$$
100 \cdot \frac{1+r}{2+r}
$$

aranykrajcárt tesz majd a bankba.

Vissza a feladathoz

\section{0. feladat:}

a. $\quad 140>126$, így megéri aláírni a szerződést.

b. Jövőre 90 garast fog elkölteni.

Vissza a feladathoz

\section{1. feladat:}

a. Eugén 168 krajcárt fog jövőre fogyasztásra költeni.

b. Ödön idén 180 krajcárt fog elkölteni, 190-t nem tud.

Vissza a feladathoz 
AZ AKTÍVÁK PIACAI 


\section{1. feladat:}

a.

$$
t=12 \text {. }
$$

b. Az összes pénze két évvel az eladás után kerekítve 81 millió, tehát meg tudja venni a másik lakást.

Vissza a feladathoz

\section{2. feladat:}

$$
x=14 \text {. }
$$

Vissza a feladathoz

\section{3. feladat:}

a. Két évvel ezelőtt legalább 910000 forintért adtam volna el Bacont.

b. A tavalyi verseny előtt legalább 671000 forintot kértem volna.

c. Közvetlenül a tavalyi verseny után 440000 forintot kértem volna.

Vissza a feladathoz

4. feladat: Évi 20 garas kifizetésú örökjáradék. (Először jövőre fizet.)

Vissza a feladathoz

5. feladat: Legfeljebb 3\% lehet a kamatláb.

Vissza a feladathoz

\section{6. feladat:}

a. A lakás jelenértéke 210000 .

b. Az éves albérleti díjak évi 3000 fityinggel nôttek.

Vissza a feladathoz 
7. feladat: Az örökjáradék jobb, mert $990>800$.

Vissza a feladathoz

8. feladat: Egy hordó olaj idén legalább 98 dinárba kerül.

Vissza a feladathoz

\section{9. feladat:}

a. Ha idén szállítanak turistákat, akkor 26.62 milliárd forint a Kft. jelenértéke.

b. Ha idén nem szállítanak turistákat, akkor 21.78 milliárd a Kft. jelenértéke.

Vissza a feladathoz 
A BIZONYTALANSÁG 
1. feladat: A keresett büntetés értéke

$$
B=156 .
$$

Vissza a feladathoz

2. feladat: Számára kedvezőbb (nagyobb várható haszonnal jár), ha a sorsjegyet megveszi tőlem.

Vissza a feladathoz

\section{3. feladat:}

a.

$$
p=\frac{1}{4}
$$

b.

$$
p^{\prime}=\frac{1}{10}
$$

Vissza a feladathoz

\section{4. feladat:}

$$
X=52 w .
$$

Vissza a feladathoz

\section{5. feladat:}

a. A fogyasztó a sorsjegy megvásárlását választja.

b.

$$
x=45 \text {. }
$$

Vissza a feladathoz 


\section{6. feladat:}

a.

$$
p=\frac{3}{8}=0.375
$$

b. Nem fizet ezért 44 garast, hanem inkább nem játszik vagy marad a kisebb nyerési esélynél.

Vissza a feladathoz

\section{7. feladat:}

a. A várható érték mindhárom portfólió mellett 625 euró.

b. Az 1. portfólió mellett:

$$
E U(1 \text {. portfólió })=50 \% \cdot \sqrt{289}+50 \% \cdot \sqrt{961}=24 .
$$

A 2. portfólió mellett:

$$
E U(2 \text {. portfólió })=25 \% \cdot \sqrt{289}+50 \% \cdot \sqrt{625}+25 \% \cdot \sqrt{961}=24.5 .
$$

A 3. portfólió mellett:

$$
E U(3 \text {. portfólió })=50 \% \cdot \sqrt{625}+50 \% \cdot \sqrt{625}=25 .
$$

c. A harmadikat, hiszen ennek a legnagyobb a várható hasznossága. Ez abból is következik, hogy Nyuszika kockázatkerülő (vagyonra vonatkozó hasznosságfüggvénye konkáv), és mindhárom alternatívában ugyanakkora a vagyon várható értéke, 625. Mivel a 3. alternatíva mellett egyáltalán nincs kockázat, Nyuszika ezt fogja választani. Nagyobb várható értékért cserébe elfogadna némi kockázatot, de itt mindegyik alternatíva várható értéke ugyanakkora (625).

Vissza a feladathoz

\section{8. feladat:}

a. Az osztályzat várható értéke 2.9.

b. A javítás várható hasznossága nagyobb, mint a nem javításé, így itt elmegy javítani. 
c. Közepes mellett is elmegy javítani.

d. Jó mellett nem megy el javítani.

e. A biztos egyenértékes $\sqrt{9.7} \approx 3.114$. Persze ilyen jegy nincs, de ha lenne, ez lenne a legkisebb, amit elfogad javítás helyett. Ha ennél rosszabbat kap, inkább elmegy javítani. És pont ezt láttuk a b., c., d. részfeladatokban. Illetve azt is látjuk, hogy a biztos egyenértékes az a. feladatban kiszámolt várható érték fölött van, vagyis a várható értéknél jobb jegyet fogadna csak el. Ez azért van, mert Chirrut kockázatkedvelő.

Vissza a feladathoz

\section{9. feladat:}

a. Igen, mert $9<10$, elfogadás esetén nagyobb Robin várható hasznossága.

b. Most legalább 156 aranyat kér.

Vissza a feladathoz

10. feladat:

a. Úgy gondolja, legalább $40 \%$ valószínúséggel veszíteni fog.

b. Mindegy nekem, hogy elfogadom-e az ajánlatot.

Vissza a feladathoz

11. feladat: Fernnek eredetileg 2501 forintja volt.

Vissza a feladathoz

\section{2. feladat:}

a. 1860 dollárja lesz sikeres felvásárlás esetén.

b. Minden részvényét ma adja el.

Vissza a feladathoz 
13. feladat:

a. 25 fontból vett kötvényeket.

b. Igen, hajlandó, mert $7.5<8.196 \approx 3+3 \cdot \sqrt{3}$.

Vissza a feladathoz 
TECHNOLÓGIA 


\section{1. feladat:}

a. Nem létezik olyan pozitív a konstans, amelyekre a technikai helyettesítési határarány értékének abszolút értéke növekvő.

b.

$$
a>\frac{1}{2} \text {. }
$$

Vissza a feladathoz

\section{2. feladat:}

a.

$$
(0<) a<1
$$

b.

$$
a>1
$$

Vissza a feladathoz

\section{3. feladat:}

a. Minden $t>1$ valós számra:

$$
t y<\left((t k)^{\frac{1}{2}}+(t l)^{\frac{1}{2}}\right)^{3}=t^{\frac{3}{2}}\left(k^{\frac{1}{2}}+l^{\frac{1}{2}}\right)^{3}=t^{\frac{3}{2}} y, \quad \text { tehát NÖVEKVŐ. }
$$

b. Minden $t>1$ valós számra:

$$
t y>\left((t k)^{\frac{1}{3}}+(t l)^{\frac{1}{3}}\right)^{2}=t^{\frac{2}{3}}\left(k^{\frac{1}{3}}+l^{\frac{1}{3}}\right)^{2}=t^{\frac{2}{3}} y, \quad \text { tehát CSÖKKENŐ. }
$$

c. Minden $t>1$ valós számra:

$$
\text { ty }>(2(t k)+3(t l))^{\frac{1}{2}}=t^{\frac{1}{2}}(2 k+3 l)^{3}=t^{\frac{1}{2}} y, \quad \text { tehát CSÖKKENŐ. }
$$

Vissza a feladathoz 


\section{4. feladat:}

a.

$$
M P_{k}(10,8,4)=1
$$

b.

$$
M P_{d}(10,8,4)=0 .
$$

Vagyis hiába kapok több disznóhúst, nem tudok több hotdogot csinálni, nincs elég kifli.

c.

$$
M P_{b}(10,8,4)=0
$$

d. Ez nem definiált, vagyis nem létezik.

e. Meglepő módon a mi definíciónk szerint ez sem létezik. Az iránymenti derivált matematikai fogalmával lehetne a helyettesítési határarányt egy kicsit bonyolultabban definiálni, ami mellett ez létezne.

\section{f. Ez sem létezik.}

Vissza a feladathoz 


\section{PROFITMAXIMALIZÁLÁS}




\section{1. feladat:}

a.

$$
b=25 \text {. }
$$

b.

$$
y=20 .
$$

c.

$$
\pi=350 \text {. }
$$

Vissza a feladathoz

\section{2. feladat:}

$$
y=\frac{\sqrt{p}}{3} .
$$

Vissza a feladathoz

3. feladat: Egy bútor elkészítésével maximalizálják a hasznukat.

Vissza a feladathoz

\section{4. feladat:}

a. A maximális elérhető nyereség (profit, haszon) 162 garas.

b. A technikai helyettesítési határarány:

$$
\operatorname{MRTS}(K, L)=-\frac{2}{1} .
$$

c. A tőke tényezőkeresleti függvénye:

$$
K(p, r, w)=\left(\frac{p^{2} \cdot 4}{r \cdot w}\right)^{2} .
$$

Vissza a feladathoz 


\section{5. feladat:}

a. A termelési függvény:

$$
f(i, t)=\sqrt{\min (2 \cdot i ; t)} .
$$

b. A határtermék a $(10,10)$ pontban:

$$
M P_{1}(10,10)=0 .
$$

c. A maximális elérhető profit:

$$
\Pi=8 \text {. }
$$

d. Az informatikusokra vonatkozó tényezőkeresleti függvény:

$$
i^{*}\left(p, w_{i}\right)=\frac{p^{2}}{2 \cdot\left(2+w_{i}\right)^{2}} .
$$

Vissza a feladathoz

\section{6. feladat:}

a. Most csak 144 munkást fognak alkalmazni, vagyis a korábbi 324-ből 180 munkást elbocsátanak.

b. A maximális rövid távú profit -24 . Zavaró lehet, hogy ez negatív, de mivel a 81 egység tốkét már kifizették, a nulla profit nem elérhető alternatíva. Az adott körülmények között a -24 az elérhető maximális profit.

c. A maximális hosszú távú profit 32 .

Vissza a feladathoz 
KÖLTSÉGMINIMALIZÁLÁS 


\section{1. feladat:}

a.

$$
c(y)=\frac{5}{4} y^{2} .
$$

b. A vállalat 700 garassal költ többet.

Vissza a feladathoz

\section{2. feladat:}

a.

$$
c(y)=\frac{1}{16} \cdot y^{4}+64 .
$$

b.

$$
\begin{gathered}
T=16, \\
\pi_{s}=-16 .
\end{gathered}
$$

c.

$$
\begin{gathered}
T=8, \quad L=2, \\
\pi=25.561 .
\end{gathered}
$$

Vissza a feladathoz

\section{3. feladat:}

a. A termelési függvény:

$$
f(d, c s, k, r)=\min (5 \cdot d ; 4 \cdot k)+\min (4 \cdot c s ; 5 \cdot r) .
$$

b. 2500 forintból.

C. A költség 2950 forintra emelkedik.

Vissza a feladathoz 


\section{4. feladat:}

a. A termelési függvény:

$$
f\left(x_{1}, x_{2}\right)=\min \left(\alpha \cdot x_{1} ; x_{2}\right) .
$$

b.

$$
\alpha=8 \text {. }
$$

c. Lineáris a termelési függvény, így a mérethozadék állandó.

Vissza a feladathoz

\section{5. feladat:}

a. A költségfüggvény:

$$
C(20,50, y)=20 \cdot y \text {. }
$$

b. A már említett három tonna feketeszénen kívül továbbra is csak lignitet fognak használni. A három tonna feketeszén pedig 150 dollárba került, és 6 energiaegységet ad:

$$
C_{S}(20,50, y, 3)=20 \cdot x_{1}+50 \cdot 3= \begin{cases}150+20 \cdot(y-6), & \text { ha } y>6 \\ 150, & \text { ha } y \leq 6 .\end{cases}
$$

c.

$$
\bar{x}_{1}=7
$$

Vissza a feladathoz

\section{6. feladat:}

a. Növekvő. Kétszeres inputfelhasználás nyolcszoros kibocsátást eredményez.

b. Az $x_{1}$ tényező iránti kereslet a paraméterek függvényében:

$$
x_{1}\left(w_{1}, 5, y\right)=\sqrt[3]{\frac{5 \cdot y}{4 \cdot w_{1}^{2}}}
$$

c. A teljes költség $C\left(w_{1}, 5, y\right)=300$. 
d. A költségfüggvény:

$$
C\left(w_{1}, 5, y\right)=3 \cdot \sqrt[3]{\frac{w_{1} \cdot 5 \cdot y}{4}} .
$$

e.

$$
w_{1}=4 \text {. }
$$

f. A rövid távú költségfüggvény:

$$
C_{s}\left(w_{1}, w_{2}, y, \bar{x}_{2}\right)=\frac{y}{400}+200 .
$$

Vissza a feladathoz 
KÖLTSÉGGÖRBÉK 


\section{1. feladat:}

a.

$$
\begin{aligned}
c(y) & =\min \left\{c_{\text {kev }}(y), c_{\text {kav }}(y)\right\}= \\
& =\left\{\begin{array}{l}
5 y^{2}, \text { ha } y \leqq 1 \\
y^{2}-2 y+6, \text { ha } y>1 .
\end{array}\right.
\end{aligned}
$$

b.

$$
\begin{aligned}
c(0.5) & =1.25 \\
c(2) & =6 .
\end{aligned}
$$

c.

$$
M C(y)=\left\{\begin{array}{l}
10 y, \text { ha } y \leqq 1 \\
2 y^{2}-2, \text { ha } y>1
\end{array}\right.
$$

Vissza a feladathoz

\section{2. feladat:}

a. A költségfüggvény:

$$
C_{A}(y)=y^{2}
$$

b. Legalább 10 kép készítése esetén éri meg befektetni.

c. A költségfüggvény:

$$
C(y)=\left\{\begin{array}{cc}
y^{2}, & \text { ha } y \leq 10 ; \\
\frac{y^{2}}{2}+50, & \text { ha } y>10 .
\end{array}\right.
$$

(Mindegy, hogy az $y=10$ részt hová rakja, ott ugyanazt az értéket adja a két képlet.)

Vissza a feladathoz

\section{3. feladat:}

a. A minimumhely $y^{*}=5$.

b. A minimum értéke $A C(5)=18$. 
c. Nem, mivel $15<18$.

d. A minimumhely $y^{*}=0$.

e. A minimum értéke $A V C(0)=8$.

Vissza a feladathoz

\section{4. feladat:}

a. A minimumhely: $y^{*}=2$. A minimum értéke: $A V C(2)=8$.

b. $p=8$.

Vissza a feladathoz

\section{5. feladat:}

a. A költségfüggvény:

$$
C(y)=\left\{\begin{array}{cc}
25, & \text { ha } y=0 \\
y^{2}+6 \cdot y+169, & \text { ha } y>0 .
\end{array}\right.
$$

b. A minimumhely: $y^{*}=13$. A minimum értéke: $A C(13)=32$.

c. $p=32$.

d. A minimumhely: $y^{*}=0$. A minimum értéke: $A C(0)=6$.

e. $p=30$.

Vissza a feladathoz

\section{6. feladat:}

a. A költségfüggvény:

$$
C(y)=6000 \cdot y^{\frac{3}{2}} .
$$


b. 36 ügyfelet szolgál ki a vállalat, $C(36)=1296000$ euró költséggel.

c. Továbbra is 36 ügyfelet szolgál ki a vállalat, és a tanácsadás költsége is marad 1296000 euró. Nem 648000, az alternatíva költség miatt. Könnyen lehet, hogy ennek az indoklását kötözködésnek érzi (pedig fontos), úgyhogy - ha gondolja - ugorjon a megoldáshoz!

Vissza a feladathoz 
VÁLLALATI KÍNÁLAT 


\section{1. feladat:}

$$
T C(y)=y^{2}+2 y+16 .
$$

Vissza a feladathoz

\section{2. feladat:}

a.

$$
a=3 \text {. }
$$

b.

$$
y=3 .
$$

c.

$$
p=3 \text {. }
$$

Vissza a feladathoz

\section{3. feladat:}

a.

$$
c(y)=\left(w_{d}+w_{m}\right) y^{2}+F=(14+16) y^{2}+500 .
$$

b.

$$
y=10 .
$$

c. A vállalat minden pozitív ár mellett termel.

Vissza a feladathoz

\section{4. feladat:}

a.

$$
y=100 .
$$

b.

$$
y=0, \quad p=2 .
$$

c.

$$
\Pi(p)=\left(\frac{p}{2}-1\right)^{2}-100 .
$$

Vissza a feladathoz 


\section{5. feladat:}

a. Üzembezárási ponthoz tartozó mennyiség $y=2$, az üzembezárási ponthoz tartozó ár $p=8$.

b. A kínálati függvény:

$$
y(p)=\left\{\begin{array}{cc}
0, & \text { ha } p<8 ; \\
\{0,2\}, & \text { ha } p=8 \\
\frac{4+\sqrt{3 \cdot p-20}}{3}, & \text { ha } p>8 .
\end{array}\right.
$$

Vissza a feladathoz

\section{6. feladat:}

a. A fix költség: $F=1$.

b. Az üzembezárási ponthoz tartozó ár: $p=2$.

c. A kínálati függvény:

$$
y(p)=\left\{\begin{array}{cc}
0, & \text { ha } p<2 ; \\
\frac{p-2}{2}, & \text { ha } p \geq 2 .
\end{array}\right.
$$

Vissza a feladathoz

\section{7. feladat:}

a. A költségfüggvény: $C(y)=12 \cdot y+6$.

b. A vállalat kínálati függvénye:

$$
y(p)= \begin{cases}0, & \text { ha } p<12 ; \\ \text { bármekkora mennyiség }, & \text { ha } p=12 ; \\ \infty, & \text { ha } p>12 .\end{cases}
$$

Vissza a feladathoz 


\section{8. feladat:}

a. A kínálati függvény: $y(p)=\frac{p}{2}$, vagy ha úgy tetszik:

$$
y(p)= \begin{cases}0, & \text { ha } p<0 ; \\ \frac{p}{2}, & \text { ha } p \geq 0 .\end{cases}
$$

b. -11 dollár hasznot, avagy 11 dollár veszteséget.

c. A kínálati függvény:

$$
y(p)= \begin{cases}0, & \text { ha } p<12 ; \\ \frac{p}{2}, & \text { ha } p \geq 12 .\end{cases}
$$

Vissza a feladathoz

\section{9. feladat:}

a. $w=80$, és nem volt kérdés, de egyébként $p=124$.

b. A fedezeti ponthoz tartozó ár: $p=120$.

Vissza a feladathoz 
IPARÁGI KÍNÁLAT 


\section{1. feladat:}

a.

$$
a=100 .
$$

b. 11 új cég lép be.

Vissza a feladathoz

\section{2. feladat:}

$$
P=350, \quad Q=500 \text {. }
$$

Vissza a feladathoz

\section{3. feladat:}

$$
b=1 \text {. }
$$

Vissza a feladathoz

\section{4. feladat:}

a.

$$
y=\frac{5}{2} .
$$

b.

$$
p=22 \text {. }
$$

c.

$$
C_{v}\left(\frac{5}{2}\right)=30 .
$$

Vissza a feladathoz

\section{5. feladat:}

a. Nulla kiló mogyorót, vagyis nem termel. A pozitív kibocsátások közül a 4 kilós a legjobb, de ennél is jobb a nulla kilós kibocsátás.

b. A magyar kínálat:

$$
y_{H}(p)=\left\{\begin{array}{cc}
0, & \text { ha } p<300 ; \\
{[0,5000],} & \text { ha } p=300 \\
5000, & \text { ha } p>300 .
\end{array}\right.
$$


c. Egyensúlyban 147 magyar vállalat lesz a piacon.

Vissza a feladathoz

\section{6. feladat:}

a. A vállalat által elérhetô legnagyobb profit $p$ függvényében:

$$
\Pi(p)=\left\{\begin{array}{cc}
0, & \text { ha } p<20 \\
\frac{p^{2}}{4}-100, & \text { ha } p \geq 20 .
\end{array}\right.
$$

b. A kínálati függvény:

$$
y(p)= \begin{cases}0, & \text { ha } p<20 ; \\ \frac{p}{2}, & \text { ha } p \geq 20 .\end{cases}
$$

c. Egy a piacra már belépett vállalat kínálati függvénye:

$$
y(p)=\frac{p}{2} .
$$

d. A rövid távú egyensúlyi ár:

$$
p^{*}=32
$$

e. A hosszú távú egyensúlyi ár:

$$
p^{*}=20,
$$

és 30 vállalat lesz a piacon.

Vissza a feladathoz

\section{7. feladat:}

a. A kínálat:

$$
y(p)=2 \cdot p .
$$

b. A profit a $p$ ár függvényében:

$$
\Pi(p)=p^{2}-4 .
$$


c. Hosszú távú egyensúlyban

$$
p^{*}=2
$$

az ár, és 15 vállalat lesz a piacon.

d. Rövid távon 15 egységgel nő a fogyasztói ár.

e. Hosszú távon 16 egységgel nő a fogyasztói ár.

Vissza a feladathoz

\section{8. feladat:}

a. Hosszú távú egyensúlyban 60 garasba kerül egy tanulmány.

b. Tizenhét közgazdász.

c. Rövid távon nem változik.

d. Hosszú távon 80 garas lesz, vagyis 20 garassal nô.

Vissza a feladathoz

\section{9. feladat:}

a. A taxisok száma $F$ függvényében:

$$
n(F)=\frac{100}{\sqrt{F}}-2 .
$$

b.

$$
F=625 \text { dollár. }
$$

Vissza a feladathoz

\section{0. feladat:}

a. 50 dollárba.

b. Rövid távon 18 dollárral, hosszú távon további 2 dollárral csökkenne az ár, 30 dollárra. 
c. A többletváltozás 198 dollár rövid távon, 100 dollár hosszú távon.

Vissza a feladathoz 
TERMELÉS 


\section{1. feladat: Annát.}

Vissza a feladathoz

\section{2. feladat:}

$$
t=96 .
$$

Vissza a feladathoz

\section{3. feladat:}

a. A könnyưipar maximális kibocsátása 200 egység.

b. A szolgáltatószektor maximális kibocsátása 800 egység.

c. A termelési lehetőségek halmazának határát implicit módon meghatározó függvény:

$$
q_{2}\left(q_{1}\right)=800-4 \cdot q_{1}
$$

Vissza a feladathoz

\section{4. feladat:}

a. A megadott kibocsátás mellett a transzformációs határarány:

$$
|\operatorname{MRT}(4,40)|=\frac{1}{10} .
$$

A helyettesítési határráták pedig:

$$
\begin{aligned}
\left|\operatorname{MRS}_{A}(3,1)\right| & =\frac{4}{3}, \\
\left|M R S_{B}(30,10)\right| & =\frac{4}{3} .
\end{aligned}
$$

b. Azon fogyasztási vektorok Pareto-hatékonyak, ahol $0 \leq x_{A} \leq 8$ és

$$
\begin{aligned}
& y_{A}=\frac{5}{2} \cdot x_{A}, \\
& x_{B}=8-x_{A}, \\
& y_{B}=20-y_{A} .
\end{aligned}
$$

Vissza a feladathoz 


\section{5. feladat:}

a. Az aggregált termelési lehetőségek halmaza a $(0,0),(36,0),(18,9)$ és $(0,15)$ pontok által határolt négyszög. Ezt nem kell lerajzolni, de azért itt van:

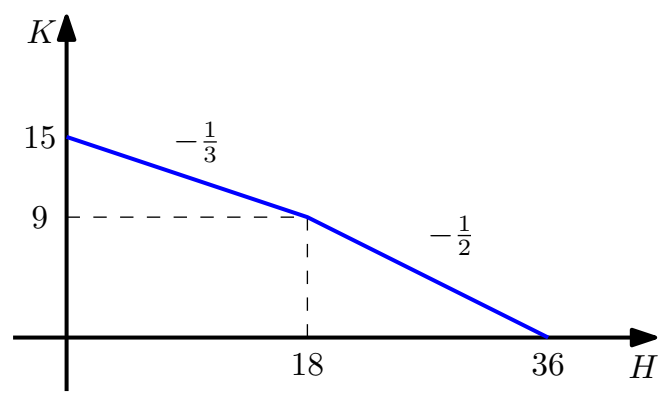

b. Azon fogyasztási vektorok Pareto-hatékonyak, ahol $0 \leq K_{R} \leq 6$, és

$$
\begin{aligned}
& H_{R}=4 \cdot K_{R}, \\
& K_{P}=6-K_{R}, \\
& H_{P}=24-H_{R} .
\end{aligned}
$$

c.

$$
\alpha=7
$$

Vissza a feladathoz

\section{6. feladat:}

a. Robinson optimális hal- $\left(y_{H}\right)$ és kókuszkibocsátása $\left(y_{K}\right)$ :

$$
\left(y_{H}, y_{K}\right)= \begin{cases}(6,0), & \text { ha } p>2 \\ \lambda \cdot(6,0)+(1-\lambda) \cdot(0,12), & \text { ha } p=2 \\ (0,12), & \text { ha } p<2\end{cases}
$$

ahol $\lambda \in[0,1]$. 
b. Robinson jövedelme:

$$
\Pi_{R}(p)= \begin{cases}6 \cdot p, & \text { ha } p>2 \\ 12, & \text { ha } p=2 \\ 12, & \text { ha } p<2\end{cases}
$$

Ez a függvény folytonos, úgyhogy a $p=2$ ágat igazából bármelyik másik ághoz hozzácsaphattuk volna, nem kell külön kezelni.

c. Robinson halfogyasztása:

$$
H_{R}(p)= \begin{cases}\frac{6 \cdot p}{p+1}, & \text { ha } p \geq 2 \\ \frac{12}{p+1}, & \text { ha } p<2 .\end{cases}
$$

Vissza a feladathoz

\section{7. feladat:}

a. $\quad p=4$ árarány mellett.

b. A termelése $q_{x}^{B}=2, q_{y}^{B}=1$, a fogyasztása $x_{B}=y_{B}=9 / 5$.

c. $a=4$.

Vissza a feladathoz

\section{8. feladat:}

a. Robinson csak halat termel, ha $p>1$, csak kókuszt, ha $p<1$, és mindegy neki hogy a $(2,0)$ és $(0,2)$ kibocsátások milyen konvex kombinációját termeli, ha $p=1$.

b. Péntek csak halat termel, ha $p>\frac{1}{2}$, csak kókuszt, ha $p<\frac{1}{2}$, és mindegy neki hogy a $(12,0)$ és $(0,6)$ kibocsátások milyen konvex kombinációját termeli, ha $p=\frac{1}{2}$.

c.

$$
p^{*}=1 / 2 \text {. }
$$

Nem volt kérdés, de az egyensúlyi kibocsátások:

$$
\left(y_{H}^{R}, y_{K}^{R}, y_{H}^{P}, y_{K}^{P}\right)=(0,2,8,2) .
$$


d. Robinson egyensúlyi halfogyasztása:

$$
H_{R}=2 .
$$

Vissza a feladathoz

\section{9. feladat:}

a. Robinson is $a=8$ órát dolgozik.

b.

$$
p^{*}=2 / 5 \text {. }
$$

c. Péntek hasznosságfüggvénye:

$$
U_{P}\left(H_{P}, K_{P}\right)=H_{P}^{\frac{3}{8}} \cdot K_{P}^{\frac{5}{8}} .
$$

Vissza a feladathoz 
A MONOPÓLIUM 


\section{1. feladat:}

a. Az állam a második megoldást választja.

b. A fogyasztók számára az adókivetés kedvezőbb.

Vissza a feladathoz

2. feladat: A monopólium maximum

$$
\Delta \pi=112
$$

garast lenne hajlandó fizetni.

Vissza a feladathoz

\section{3. feladat:}

a. Az optimális termelés 9 egység.

b. A monopólium haszna 76 egység.

c. A fix költség az optimális termelést nem befolyásolja, az marad 9. De a profit lecsökken 68-ra.

Vissza a feladathoz

\section{4. feladat:}

a. Az optimális ár 11 egység.

b. A kereslet árrugalmassága:

$$
\varepsilon_{D}(11)=-\frac{11}{9}
$$

c. A fix költség az optimális termelést nem befolyásolja. Így a profit akkor lesz maximális, amikor a monopólium bevétele (a fogyasztók kiadása) maximális. Ez pedig, mint tanultuk, $\varepsilon(p)=-1$-nél van.

Vissza a feladathoz 


\section{5. feladat:}

a.

$$
a=18 \text {. }
$$

b. A holtteherveszteség 18 egység.

c. Az összes kifizetett támogatás:

$$
t \cdot y_{v}=18 \cdot 9=162 \text {. }
$$

Vissza a feladathoz

\section{6. feladat:}

a.

$$
a=8 \text {. }
$$

b.

$$
y^{*}=0 .
$$

Vissza a feladathoz 
MONOPOLISTA VISELKEDÉS 


\section{1. feladat:}

a.

$$
Q=5.5 \text {. }
$$

b.

$$
p_{\ddot{o}}=17.25 \text {. }
$$

c.

$$
p_{r}=17.25 \text {. }
$$

Vissza a feladathoz

\section{2. feladat:}

$$
a=5 \text {. }
$$

Vissza a feladathoz

\section{3. feladat:}

a.

$$
Y=77 \text {. }
$$

b.

$$
\pi=1694 .
$$

c. A monopolista pénzt egyáltalán nem áldoz a rendelet eltörlésére.

Vissza a feladathoz

4. feladat: Egy fityinget sem hajlandó fizetni a szakértőnek.

Vissza a feladathoz

5. feladat: A kaliforniai ár 20, a New York-i ár 21 dollár.

Vissza a feladathoz

\section{6. feladat:}

a. Tíz egységet. 
b. Tizenkét egységet.

c. A profit 30 egységgel nő, 143 egységről 173 egységre.

d. Fogyasztói többlet 25 egységgel csökken, 25 egységről 0 egységre.

Vissza a feladathoz

\section{7. feladat:}

a. A bevételmaximalizáló árak $p_{t}=13, p_{d}=3$.

b. A profitmaximalizáló ár $p^{*}=13$.

c. Az elsô esetben volt nagyobb a fogyasztói többlet, hisz a teljes árú jegyet vásárlók ott is ilyen ár mellett vásároltak, a diákok pedig olcsóbb áron vehettek jegyet, és vettek is.

d. Az elsố esetben a profit sem lehetett kisebb, mivel a monopóliumnak ott nagyobb szabadsága volt az árak meghatározásában. Azaz ha a diszkrimináló árak mellett a profit kisebb lenne, mint az egyenár mellett, a monopólium egyszerúen önként egyenárat vezethetne be, és ezzel növelni tudná profitját. Mivel a diszkrimináló árak profitmaximalizálóak voltak, ezért ez nem lehet, vagyis a diszkrimináló profit nem lehet kisebb, mint az egyenáras profit.

A jólét a fogyasztói többlet és a profit összege (plusz fix költség). Mivel a diszkrimináló esetben a fogyasztói többlet nagyobb, a profit meg nem kisebb, mint az egyenáras esetben, a jólét is nagyobb lesz.

Vissza a feladathoz

\section{8. feladat:}

a. Az optimális fesztiváli ár $p_{F}=900$.

b. 150 forintba.

Vissza a feladathoz

\section{9. feladat:}

a. 15 bérletet ad ingyen, 25 bérletet elad. 
b. A haszon 950 egység.

c. A holtteherveszteség 80 egység.

d. Továbbra is 15 bérletet kell ingyen biztosítani, de most nem éri meg az összes többi lakót kiszolgálni, csak 57-et. A haszon most 3980 egység, a holtteherveszteség pedig 180 egység.

Vissza a feladathoz 
TÉNYEZŐPIACOK 


\section{1. feladat:}

$$
y=15 .
$$

Vissza a feladathoz

\section{2. feladat:}

a.

$$
w=20 \text {. }
$$

b.

$$
\pi=1250 .
$$

Vissza a feladathoz

\section{3. feladat:}

$$
L=100, \quad w=600 .
$$

Vissza a feladathoz

4. feladat: A BT számára mindegy, melyik opciót választja.

Vissza a feladathoz

\section{5. feladat:}

a. A határtermék-bevétel:

$$
\operatorname{MRP}(x)=\frac{100}{\sqrt{x}}-4
$$

b. A tényezőkeresleti függvény:

$$
x(w)=\left(\frac{100}{w+4}\right)^{2} .
$$

Vissza a feladathoz

\section{6. feladat:}

$$
p=40 \text {. }
$$

Vissza a feladathoz 


\section{7. feladat:}

a. Két földmúvest.

b. A munkabér 200 euró.

Vissza a feladathoz

\section{8. feladat:}

$$
w=2 .
$$

Vissza a feladathoz 
OLIGOPÓLIUM 


\section{1. feladat:}

a.

$$
y_{1}=3, \quad y_{2}=5.5 .
$$

b. A vezérlő termelése

$$
\Delta y_{1}=-2
$$

egységgel változik.

Vissza a feladathoz

\section{2. feladat:}

a.

$$
Y=\left(y_{C}+y_{R}\right)=40 .
$$

b.

$$
y_{C}^{*}=30 .
$$

c. Miután kartell esetén a Csipke Bt. profitja alacsonyabb, mint a másik esetben, ezért Hófehérke megkapja a 70 aranytallért.

Vissza a feladathoz

\section{3. feladat:}

$$
y_{2}=6
$$

Vissza a feladathoz

\section{4. feladat:}

a. Javaharlal 16 jakszőrme eladásával maximalizálja profitját.

b. Most 11 jakszőrmét kell eladnia a profitmaximumhoz.

c. Jelöljük $y_{M}$-mel Mohandas termelését. A reakciófüggvény:

$$
y_{J}\left(y_{M}\right)=21-\frac{y_{M}}{2} .
$$

Vissza a feladathoz 


\section{5. feladat:}

a. 18 üveggolyó gyártásával.

b. Az elsố vállalat reakciófüggvénye:

$$
y_{1}\left(y_{2}\right)=28-\frac{y_{2}}{2} .
$$

c. A második vállalatnak ekkor 19 üveggolyót éri meg termelnie.

d. A második vállalat azt szeretné elhitetni az elsô vállalattal, hogy legalább 56 lesz a kibocsátása.

Vissza a feladathoz

6. feladat: A piacon kialakuló egyensúlyi ár 55 dollár.

Vissza a feladathoz

\section{7. feladat:}

a. Az elsô vállalat reakciófüggvénye:

$$
y_{1}\left(y_{2}\right)=30-\frac{y_{2}}{2} .
$$

b. A második vállalat reakciófüggvénye:

$$
y_{2}\left(y_{1}\right)=30-\frac{y_{1}}{2} .
$$

c. A $(20,20)$ kibocsátáspár egyensúly.

Vissza a feladathoz

\section{8. feladat:}

a. Nulla forint a második fagyizó haszna.

b. Most -10000 forint a haszna.

c. Most 1200 forint a haszna. 
d. Az egyetlen egyensúly $\left(p_{1}, p_{2}\right)=(150,150)$.

Vissza a feladathoz

9. feladat: $p=10$ nagyságú árat.

Vissza a feladathoz

10. feladat:

$$
a=135 \text {. }
$$

Vissza a feladathoz

11. feladat: Legfeljebb 28 pénzegységet.

Vissza a feladathoz

12. feladat: Legalább hat vállalat van a piacon.

Vissza a feladathoz 
KÜLSŐ GAZDASÁGI HATÁSOK 


\section{1. feladat:}

a.

$$
k^{*}=25-0.25 c .
$$

b.

$$
\sum T_{\text {Pigou }}=25 c-0.25 c^{2}
$$

c. A mütyürtermelés nagysága nem változik.

Vissza a feladathoz

\section{2. feladat:}

a.

$$
c=6, \quad h=18 \text {. }
$$

b. Összesen maximum

$$
5+17=22
$$

órát töltenek a tavon.

Vissza a feladathoz

\section{3. feladat:}

a.

$$
\Pi^{n}=-1500 .
$$

b. A navajók felvásárolják a komancsok vállalkozását, és magukra vállalják a csaták bemutatását is.

Vissza a feladathoz

\section{4. feladat:}

a. Két egység energiát.

b. Hat egység energia termelése lenne társadalmilag optimális.

c. $t=8$ peták mennyiségi támogatás szükséges. 
d. 8 peták lenne az egyensúlyi ár is.

e. Az egyensúlyi mennyiség továbbra is 6 , azaz 4 háztartástól vásárolja vissza a jogokat az erőmú.

Vissza a feladathoz

\section{5. feladat:}

a. Négy halat.

b. Társadalmi optimumban 14 egység acélt termelnének.

c. A halászok profitja:

$$
\Pi_{f}=60 .
$$

Vissza a feladathoz

\section{6. feladat:}
a. 90 taxi lesz New Yorkban.
b. 45 engedélyt.
c. Egy engedély 45 dollárt ér.
d. Nem az.

Vissza a feladathoz

\section{7. feladat:}

a. Karnataka 12, Tamil Nadu 6 köbkilométer vizet használ fel.

b. 8 köbkilométert.

c. Az egyensúlyi ár 8 crore rúpia.

Vissza a feladathoz 
KÖZJAVAK 


\section{1. feladat:}

a.

$$
p=2.5 \text {. }
$$

b.

$$
q^{*}=16
$$

c.

$$
N=10 \text {. }
$$

Vissza a feladathoz

\section{2. feladat:}

a.

$$
v^{o}=6 .
$$

b.

$$
v^{*}=0 .
$$

Vissza a feladathoz

\section{3. feladat:}

a. Az egyéni mújégpályák $25 \mathrm{~m}^{2}$ nagyságúak lesznek, tehát a legnagyobb is ekkora.

b. A közös mújégpálya Pareto-hatékony mérete $10000 m^{2}$.

Vissza a feladathoz

\section{4. feladat:}

a. Fejenként 1 dollárt, összesen 8 dollárt.

b. Fejenként 8 dollárt, összesen 64 dollárt.

c. Nagyobb a fogyasztók hasznossága, amikor mindenki a saját számláját fizeti.

Vissza a feladathoz 


\section{5. feladat:}

a. A társadalmi optimumban $g^{*}=2500$ auno sol az állami kiadás.

b. Nem tudni, hogy pontosan kik mennyit fizetnek be, de összesen $\frac{1}{4}$ auno solt fizetnek.

c.

$$
275>250.5,
$$

nagyobb a hasznosság, ha mindenki betartja az adótörvényeket, mintha senki sem.

Vissza a feladathoz 
III. rész

Megoldások 
INTERTEMPORÁLIS VÁLASZTÁSOK 
1. feladat: A János jövedelemáramlásából számított intertemporális költségvetési halmaz mindig tartalmazza Pálét, hiszen elsô időszaki jövedelme nagyobb, mint társáé, a második időszaki jövedelmek egyenlőek. Emiatt János elérhető maximális hasznossága mindig nagyobb (sosem kisebb), mint Pálé, ugyanis hasznossági függvényük ugyanaz. Ebből következően a rawlsi jóléti függvény, ami kettejük hasznosságának minimuma, mindig Pál maximális hasznosságának megfelelő értéket vesz fel.

Miután Pál intertemporális hasznossági függvénye szimmetrikus C-D-típusú, ezért az elsố idôszaki fogyasztása a jövedelemáramlás jelenértékének, második idôszaki fogyasztása a jövedelemáramlás jövőértékének a fele:

$$
\begin{aligned}
& c_{1}=\frac{1}{2}\left(200+\frac{1}{1+0.21} 110\right), \\
& c_{2}=\frac{1}{2}((1+0.21) 200+110) .
\end{aligned}
$$

Pál

$$
U\left(c_{1}, c_{2}\right)=c_{1} c_{2}
$$

hasznossága ezekből:

$$
\left(\frac{1}{2}\left(200+\frac{1}{1+0.21} 110\right)\right) *\left(\frac{1}{2}((1+0.21) 200+110)\right)=25600 .
$$

Vissza a feladathoz

2. feladat: Anna hasznossági függvénye speciális, szerkezete összetett. Az időszakokon belüli fogyasztására vonatkozó preferenciái tökéletes kiegészítők, a két idôszaki (kompozit) fogyasztására vonatkozóak pedig C-D-típusúak. Az is nyilvánvaló, hogy fogyasztása csak akkor lehet optimális, ha az időszakon belüli fogyasztási szerkezete az. A két időszak ebből a szempontból ugyanolyan, ha a $t$-edik időszakban $m_{t}$ forintot költhetünk, akkor a feladat:

$$
\begin{aligned}
& \max \left\{\min \left\{f_{t}, 2 h_{t}\right\}\right\}, \\
& 2 f_{t}+1 h_{t}=m_{t} .
\end{aligned}
$$

Ennek megoldása, felhasználva, hogy optimumban

$$
f_{t}=2 h_{t},
$$

és behelyettesítve pedig

$$
2\left(2 h_{t}\right)+h_{t}=m_{t},
$$


amiből:

$$
\begin{aligned}
h_{t} & =\frac{m_{t}}{5}, \\
f_{t} & =\frac{2 m_{t}}{5} .
\end{aligned}
$$

Miután a hasznossági függvény olyan, amilyen (szimmetrikus C-D-típusú), ezért tudjuk, hogy az első időszaki fogyasztásra a jövedelemáramlás jelenértékének felét költi Anna, azaz:

$$
m_{1}=\frac{100}{2}=50 \text {. }
$$

Összevetve az időszakon belüli optimális fogyasztás képletével kapjuk, hogy:

$$
f_{1}=20 \text {. }
$$

Vissza a feladathoz

3. feladat: Cilike hasznossági függvénye pozitív monoton transzformáltja a következő hasznossági függvénynek:

$$
U\left(x_{0}, x_{1}\right)=x_{0}^{a} x_{1}^{4} .
$$

Ha a preferenciák ilyen alakúak, akkor:

$$
\begin{aligned}
& x_{0}=\frac{a}{a+4} P V\left(m_{0}, m_{1}\right)=\frac{a}{a+4}\left(m_{0}+\frac{1}{1+r} m_{1}\right), \\
& x_{1}=\frac{4}{a+4} F V\left(m_{0}, m_{1}\right)=\frac{4}{a+4}\left((1+r) m_{0}+m_{1}\right) .
\end{aligned}
$$

A feltétel szerint

$$
x_{0}=2 x_{1},
$$

valamint a kamatláb 50\%-os, ezekból:

$$
\frac{a}{a+4}\left(m_{0}+\frac{1}{1+.5} m_{1}\right)=2 * \frac{4}{a+4}\left((1+.5) m_{0}+m_{1}\right),
$$

azaz

$$
\frac{a}{a+4}\left(m_{0}+\frac{1}{1+.5} m_{1}\right)=2 * \frac{4}{a+4} * 1.5\left(m_{0}+\frac{1}{1+.5} m_{1}\right) .
$$

Elvégezve az egyszerúsítést:

$$
a=12 \text {. }
$$

Vissza a feladathoz 
4. feladat: Hugi preferenciái C-D-típusúak. Ha azt a reprezentációt vesszük, amiben a kitevők összege egységnyi, akkor hasznossági függvénye:

$$
U\left(x_{0}, x_{1}\right)=x_{0}^{0.6} x_{1}^{0.4}
$$

Tudjuk (órán megmutattuk, lehet rá hivatkozni), hogy ekkor az elsô időszaki kereslet a jövedelemáramlás jelenértékének az elsô kitevôvel vett szorzata, a második időszaki kereslet pedig a jövedelemáramlás jövőértékének a második kitevővel vett szorzata.

a. Hugi jövedelemáramlásának jelenértéke:

$$
m_{0}+\frac{m_{1}}{1+r}=400+\frac{480}{1.2}=800
$$

tehát idén

$$
x_{0}=0.6 * 800=480
$$

értékû fogyasztási cikket vásárol.

b. Ha az idei jövedelme megemelkedik, akkor a jövedelemáramlásának jelenértéke:

$$
m_{0}^{\prime}+\frac{m_{1}}{1+r}=800+\frac{480}{1.2}=1200,
$$

az új fogyasztása:

$$
x_{0}^{\prime}=0.6 * 1200=720,
$$

azaz az idei fogyasztása

$$
x_{0}^{\prime}-x_{0}=720-480=240
$$

egységgel nőtt.

Vissza a feladathoz

\section{5. feladat:}

a. Mivel Csabi Dani hasznosságfüggvénye szimmetrikus Cobb-Douglas, ezért az első évben a jövedelemáramlása jelenértékének felét fogyasztja, azaz:

$$
620=\frac{600+\frac{1}{1+0.1} m_{2}}{2},
$$

amiből:

$$
m_{2}=704
$$


b. A második évben nyert, ezért - miután kamatostul visszafizette a hitelbe felvett pénzt - pontosan ötször annyi fogyasztási cikket vásárolhatott, mint a nyeremény nélkül. Ha nem nyert volna, akkor a jövedelemáramlása jövőértékének a felét fogyasztotta volna, azaz:

$$
x_{2}=\frac{(1+0.1) 600+704}{2}
$$

A fentiek miatt:

$$
5 x_{2}=5\left(\frac{(1+0.1) 600+704}{2}\right)=704-20(1+0.1)+X,
$$

ahol $X$ a nyeremény. Ebből:

$$
X=2728 \text {. }
$$

c. Ha a nyereményben biztos lett volna, akkor az idei költése

$$
x_{1}^{*}=\frac{600+\frac{704+2728}{1.1}}{2}=1860
$$

lett volna.

Vissza a feladathoz

6. feladat: Abraxas hasznossági függvénye speciális, szerkezete összetett. Az idôszakokon belüli fogyasztására vonatkozó preferenciái tökéletes kiegészítők, illetve tökéletes helyettesítők, a két időszaki (kompozit) fogyasztására vonatkozóak pedig C-Dtípusúak. Az is nyilvánvaló, hogy fogyasztása csak akkor lehet optimális, ha az idôszakon belüli fogyasztási szerkezete az. A két időszak ebből a szempontból eltérô.

Ha az első időszakban $m_{1}$ forintot költhet, akkor a feladat:

$$
\begin{aligned}
& \max \left\{\min \left\{g_{1}, d_{1}\right\}\right\}, \\
& 1 g_{1}+3 d_{1}=m_{1} .
\end{aligned}
$$

Ennek megoldása, felhasználva, hogy optimumban

$$
g_{1}=d_{1},
$$

és behelyettesítve:

$$
4 g_{1}=m_{1},
$$

amiből:

$$
g_{1}=d_{1}=\frac{m_{1}}{4} .
$$

Ha a második időszakban $m_{2}$ forintot költhet, akkor a feladat:

$$
\begin{aligned}
& \max \left\{g_{2}+d_{2}\right\}, \\
& 1 g_{2}+3 d_{2}=m_{2} .
\end{aligned}
$$


Ennek megoldása, felhasználva, hogy a gitárzene olcsóbb, ezért csak arra költ:

$$
g_{2}=m_{2} \text {. }
$$

Miután a hasznossági függvény olyan, amilyen (szimmetrikus C-D-típusú az időszakok fogyasztásában), ezért tudjuk, hogy az első időszaki fogyasztásra a jövedelemáramlás jelenértékének felét költi Abraxas, azaz:

$$
m_{1}=\frac{100+\frac{1}{1.1} 110}{2}=100 .
$$

Ebből:

$$
g_{1}=\frac{100}{4}=25 \text {. }
$$

A második időszakban jövedelemáramlása jövőértékének a felét költi:

$$
m_{2}=\frac{1.1 \cdot 100+110}{2}=110 .
$$

Ebből pedig:

$$
g_{2}=110
$$

azaz

$$
g_{2}-g_{1}=110-15=85
$$

egység gitárzenével nő a fogyasztása.

Vissza a feladathoz

7. feladat: Kronosz hasznosságfüggvénye szimmetrikus Cobb-Douglas. Jövedelmének jövőértéke $60+60 \cdot 1.2=132$. Ennek felét, 66 garast költi jövő évi fogyasztásra. A Cobb-Douglas-tulajdonság intertemporális alkalmazásánál vigyázzunk arra, hogy a mai pénz nem ugyanaz, mint a jövőbeli pénz. A mai fogyasztás kiszámításánál ezért a jövedelem jelenértékét, a jövő évi fogyasztásnál a jövedelem jövőértékét vizsgáljuk. Ha ez vodoonak túnik: korábbi tanulmányainkból tudjuk, hogy ha a hasznosságfüggvény Cobb-Douglas-típusú, vagyis:

$$
U\left(c_{1}, c_{2}\right)=\alpha \cdot \ln c_{1}+(1-\alpha) \cdot \ln c_{2}
$$

(vagy ennek monoton transzformációja), akkor a keresleti függvények:

$$
c_{1}=\alpha \cdot \frac{m}{p_{1}}, \quad c_{2}=(1-\alpha) \cdot \frac{m}{p_{2}},
$$

ahol $m$ a jövedelem, $p_{1}$ és $p_{2}$ pedig az árak. Intertemporális probléma esetén célszerú eldönteni, hogy milyen mértékegységben szeretnénk mérni a pénzt, mai pénzben vagy más időszakbeli (például egy év múlva megkapott) pénzben? Legyen most a mértékegységünk, mondjuk, a mai pénz. Ekkor $m$ jövedelemáram jelenértéke, az idei fogyasztásra 
költött pénz ára (nyilván) 1, a jövőre fogyasztásra költött pénz idei pénzben mért ára pedig $1 / 1+r$. Így az idei fogyasztásra tényleg a jövedelem jelenértékének az $\alpha$ részét (jelen feladatban felét) fogja elkölteni a fogyasztó:

$$
c_{1}=\alpha \cdot \frac{\mathrm{PV}}{1}=\alpha \cdot \mathrm{PV},
$$

ahol PV a jövedelemáram jelenértéke. A jövő évi fogyasztásra a jelenérték $1-\alpha$ részét (most felét) fogja költeni, de jövő évi pénzben mérve ez persze más, mint jelenértékben mérve.

$$
c_{2}=(1-\alpha) \cdot \frac{\mathrm{PV}}{\frac{1}{1+r}}=(1-\alpha) \cdot \mathrm{PV} \cdot(1+r)=(1-\alpha) \cdot \mathrm{FV},
$$

ahol FV a jövedelemáram (egy évvel későbbi) jövőértéke. Ebben a feladatban

$$
c_{2}=(1-\alpha) \cdot \mathrm{FV}=\frac{1}{2} \cdot 132=66 .
$$

Vissza a feladathoz

\section{8. feladat:}

a. Minden a feladatban szereplő ár osztható 10-zel. Ezért időmegtakarítás céljából célszerú azt mondani, hogy 10 forintokban számolunk minden pénzt, így számolhatunk kisebb számokkal. Ez csak nominális változás, az árarányok nem változnak, minden reálmennyiség ugyanakkora lesz, mintha az eredeti számokkal számoltunk volna. A (10 forintban mért) jövedelem jelenértéke:

$$
P V(m)=3200+\frac{3534}{1+14 \%}=6300 .
$$

Ebből ma

$$
\frac{6300}{18}=350
$$

kiló brokkolit vehetünk.

b. A jövedelem jövőértéke (ha az ideit mind bankba tesszük, és ehhez a jövő évit hozzávesszük, ennyi pénzünk lesz jövőre):

$$
F V(m)=3200 \cdot(1+14 \%)+3534=7182 .
$$

Ebből jövőre

$$
\frac{7182}{19}=378
$$

kiló brokkolit vehetünk. 
c. Ha idén egy egységgel kevesebb reáljószágot (brokkolit) fogyaszt, jövőre hány egységgel több reáljószágot vehet? Az arány a reálkamatlábat határozza meg: mennyit kamatozik az a reáljószág, amelyről ma lemondok. Most

$$
\frac{p_{1}}{p_{2}} \cdot(1+r)=\frac{18}{19} \cdot(1+14 \%)=108 \%,
$$

így a reálkamatláb $8 \%$.

Ugyanezt egyébként a költségvetési halmaz előbb kiszámolt két szélső pontjából is megkaphatjuk. Ha minden jövedelmet idén költ el, a fogyasztó 350 kiló brokkolit vehet. Ha idén mindent megtakarítana és jövőre költené el a jövedelmét, akkor 378 kiló brokkolit vehet.

$$
\frac{378}{350}=108 \%
$$

d. Az MRS-feltételből:

$$
\begin{aligned}
\left|\operatorname{MRS}\left(x_{1}, x_{2}\right)\right| & =\frac{p_{1}}{p_{2}} \cdot(1+r), \\
\frac{1}{\frac{5}{6}} \cdot \sqrt{\frac{x_{2}}{x_{1}}} & =108 \%, \\
\sqrt{\frac{x_{2}}{x_{1}}} & =\frac{9}{10} \\
x_{2} & =x_{1} \cdot \frac{81}{100} .
\end{aligned}
$$

Ezt behelyettesítve a költségvetési korlátba (mondjuk a jövőértékes alakba, de a jelenértékes is jó, sőt azzal szebbek a köztes számok):

$$
\begin{aligned}
m_{1} \cdot(1+r)+m_{2} & =x_{1} \cdot p_{1} \cdot(1+r)+x_{2} \cdot p_{2}, \\
3200 \cdot(1+14 \%)+3534 & =x_{1} \cdot 18 \cdot(114 \%)+x_{2} \cdot 19, \\
7182 & =x_{1} \cdot 18 \cdot 114 \%+x_{1} \cdot \frac{81}{100} \cdot 19, \\
m & =x_{1} \cdot(20.52+15.39)=x_{1} \cdot 35.91, \\
x_{1}=200 & x_{2}=200 \cdot \frac{81}{100}=162 .
\end{aligned}
$$

Vissza a feladathoz 


\section{9. feladat:}

a. Az MRS-feltételből:

$$
\begin{aligned}
\left|\operatorname{MRS}\left(c_{1}, c_{2}\right)\right| & =\sqrt{\frac{c_{2}}{c_{1}}}=1+r, \\
\frac{c_{2}}{c_{1}} & =(1+r)^{2}, \\
\frac{c_{2}}{1+r} & =(1+r) \cdot c_{1} .
\end{aligned}
$$

Ezt behelyettesítve a költségvetési korlátba:

$$
\begin{aligned}
c_{1}+\frac{c_{2}}{1+r} & =100, \\
c_{1}+(1+r) \cdot c_{1} & =(2+r) \cdot c_{1}=100, \\
c_{1} & =\frac{100}{2+r} .
\end{aligned}
$$

Annyit rak be a bankba, amennyit nem költ el ma, azaz

$$
100-c_{1}=100-\frac{100}{2+r}=100 \cdot \frac{1+r}{2+r}
$$

aranykrajcárt. A szöveg szerint

$$
100 \cdot \frac{1+r}{2+r}=60,
$$

ebből:

$$
\begin{aligned}
100+100 \cdot r & =120+60 \cdot r, \\
40 \cdot r & =20, \\
r & =\frac{1}{2} .
\end{aligned}
$$

b. Ezt már az előző pontban megválaszoltuk,

$$
100 \cdot \frac{1+r}{2+r}
$$

aranykrajcárt tesz majd a bankba.

Vissza a feladathoz 


\section{0. feladat:}

a. Ha Ignác jövedelempályájának jelenértéke $x$, akkor költségvetési korlátja (jelenértékes alak):

$$
x=c_{1}+\frac{c_{2}}{1+r} .
$$

Hasznosságfüggvénye Cobb-Douglas-típusú, így optimumban:

$$
\begin{aligned}
c_{1}^{*} & =\frac{4}{7} \cdot \frac{x}{1}, \\
c_{2}^{*} & =\frac{3}{7} \cdot \frac{x}{\frac{1}{1+r}} .
\end{aligned}
$$

A kamatláb adott, $r=50 \%$. A múködő hitelpiac mellett a fenti képletek alapján Ignác fogyasztása annál nagyobb, minél nagyobb a jövedelme jelenértéke. Az azonos jelenértékú jövedelemáramok ugyanolyan jók számára, mindegy, hogy ezek közül melyiket kapná. Ignác két lehetséges alternatíváját így a jelenértékeik alapján kell értékelnünk. Ha nem írja alá a szerződést, jövedelempályájának jelenértéke

$$
-100+\frac{339}{1+50 \%}=126
$$

garas. Ha aláírja a szerződést, jövedelempályájának jelenértéke

$$
0+\frac{210}{1+50 \%}=140>126
$$

garas, azaz megéri aláírni a szerződést.

b. A Cobb-Douglas-tulajdonság alapján:

$$
c_{2}^{*}=\frac{3}{7} \cdot \frac{140}{\frac{1}{1+50 \%}}=90 .
$$

Vissza a feladathoz 


\section{1. feladat:}

a. A testvérek vagyonának jelenértéke a városukban elérhető kamatláb mellett:

$$
180+\frac{162}{1+r}
$$

A Cobb-Douglas-tulajdonság alapján:

$$
\begin{aligned}
c_{1}^{*} & =\frac{5}{9} \cdot \frac{180+\frac{162}{1+r}}{1}, \\
c_{2}^{*} & =\frac{4}{9} \cdot \frac{180+\frac{162}{1+r}}{\frac{1}{1+r}} .
\end{aligned}
$$

Eugén esetében a kamatláb 20\%, így:

$$
\begin{aligned}
& c_{2}^{*}=\frac{4}{9} \cdot \frac{180+\frac{162}{1.2}}{\frac{1}{1.2}}, \\
& c_{2}^{*}=\frac{4}{9} \cdot 315 \cdot 1.2=168 .
\end{aligned}
$$

b. Ödön esetében a kamatláb 0, így:

$$
c_{1}^{*}=\frac{5}{9} \cdot \frac{180+\frac{162}{1}}{1}=190 .
$$

Azonban ez meghaladja jelenlegi jövedelmét (190 > 180), és városában nincs bankrendszer. Így fogyasztása szélsố ponti lesz: A lehetố legnagyobb olyan összeget költi idén fogyasztásra, amit megengedhet magának, azaz 180 krajcárt. Az MRS-feltételből következő Cobb-Douglas-tulajdonság azért vezetett hibás megoldásra, mert használatakor feltételezzük, hogy a megoldás belsô ponti.

Vissza a feladathoz 
AZ AKTÍVÁK PIACAI 
1. feladat: A lakást akkor adja el, ha a bérleti díj plusz az értéknövekedés már nem magasabb, mint az a kamat, amit az eladási ár utáni egy évben kap.

a. Minden $t$-edik évben ugyanis két lehetősége van: vagy eladja a lakást, és kap érte

$$
20+1.6 t
$$

millió forintot, vagy nem adja el, és akkor még egy évig kapja a 2.32 millió bérleti díjat. A következő évben az ingatlan

$$
20+1.6(t+1)
$$

millió forintot ér. Ezt azonban csak akkor kaphatja meg, ha a lakást az előző évben nem értékesítette. Ezekből:

$$
0.1(20+1.6 t)=2.32+1.6=3.92
$$

ahonnan:

$$
t=12 \text {. }
$$

b. Az összes pénze két évvel az eladás után pedig

(eladási ár + összes bérleti díj) jövőértéke (kerekítve):

$$
1.1^{2} *((20+1.6 * 12)+(12 * 2.32)) \simeq 81 \text { millió, }
$$

tehát meg tudja venni a másik lakást.

Vissza a feladathoz

2. feladat: Jelöljük $T$-vel azt az idôpontot, amikor eladom a bort! Ekkor kapok érte

$$
x+6 * T
$$

garast. Ha ezt a pénzt beteszem a bankba, akkor az utána járó egyéves kamat:

$$
0.1(x+6 * T) \text {. }
$$

Akkor adom el, ha ez a kamat meghaladja azt az összeget, amennyit azon nyernék, ha borban hagytam volna a pénzem. Ez most esetünkben

$$
6-1=5
$$

garas. Ezeket összevetve, és figyelembe véve hogy $T=6$, kapjuk, hogy:

$$
0.1(x+6 * 6)=5
$$

amiből:

$$
x=14 \text {. }
$$

Vissza a feladathoz 


\section{3. feladat:}

a. Mai pénzben számolva: a két éve kapott 300000 forint 10\%-os kamatozással ma

$$
300000 \cdot 1.1^{2}=363000
$$

forintot ér. A tavaly kapott 231000 forint

$$
231000 \cdot 1.1=254100
$$

mai forintot ér. A vágóhídtól most kapott 484000 forint pedig értelemszerúen 484000 mai forintot ér, így Bacon összesen

$$
363000+254100+484000=1101100
$$

mai forintnak megfelelő jövedelmet nyújtott nekem. Ha két évvel korábban a verseny előtt eladom $x$ forintért, akkor az ma $x \cdot 1.1^{2}$ forintot érne. Akkor járnék ugyanilyen jól, ha

$$
\begin{aligned}
x \cdot 1.1^{2} & =1101100 \\
x & =910000
\end{aligned}
$$

forintért adtam volna el.

Ugyanez két évvel ezelőtti pénzben számolva: a malacból származó pénzáramlás (cashflow) két évvel ezelőtti pénzben mért értéke

$$
300000+\frac{231000}{1.1}+\frac{484000}{1.1^{2}}=300000+210000+400000=910000 .
$$

b. Az előző ponthoz képest két különbség van. Egyrészt Baconért nem két éve, hanem tavaly kapom a pénzt, így csak egyszer kamatozna, másrészt a két évvel ezelőtti versenyen még mindenképpen az én tulajdonom, ezért az ott kapott díjat figyelmen kívül hagyhatom, amikor az eladási árat mérlegelem. Így Bacon tavalyi, verseny előtti értéke (tavalyi pénzben mérve):

$$
231000+\frac{484000}{1.1}=231000+440000=671000 .
$$

Ezt úgy is kiszámolhattuk volna, hogy az előző pontban már megállapítottuk, hogy két évvel ezelőtt, a verseny előtt 910 eFt-t ért Bacon. Ebből 300000 forint a két évvel ezelőtti verseny díja, enélkül, vagyis a verseny után, 610000 két évvel ezelőtti forintot ért. Ezt átszámolva egy évvel ezelőtti forintba:

$$
610000 \cdot 1.1=671000 .
$$


c. Lényegében az a kérdés, hogy ha a vágóhíd hajlandó már tavaly fizetni azért, hogy idén megkapják a disznót, mennyit kérek érte. Hogy kamatozás után ugyanilyen jól jöjjek ki, legalább

$$
\frac{484000}{1.1}=440000
$$

forint kell. Ezt úgyis megkaphatom, hogy Bacon tavalyi 671000 forintos értékéből 231000 forint a tavalyi verseny díja, enélkül már csak

$$
671000-231000=440000
$$

tavalyi forintot ér.

A feladat tanulsága annyi lenne, hogy figyeljünk arra, hogy mi a pénz „,mértékegysége”, vagyis melyik időszakbeli pénzzel számolunk. Amíg ezt nem rontjuk el, elég sok jó megoldás van. Ha ezt elrontjuk, akkor a Cobb-Douglas-tulajdonság és a többi csodaképlet sem múködik.

Vissza a feladathoz

4. feladat: Ha egy örökjáradék $x$ garast fizet minden évben (először jövőre), akkor jelenértéke:

$$
\begin{aligned}
\frac{x}{1+r}+\frac{x}{(1+r)^{2}}+\frac{x}{(1+r)^{3}}+\ldots & =\frac{1}{1+r}\left(1+\frac{x}{1+r}+\frac{x}{(1+r)^{2}}+\ldots\right), \\
\frac{1}{1+r}\left(1+\frac{x}{1+r}+\frac{x}{(1+r)^{2}}+\ldots\right) & =\frac{1}{1+r} \cdot \frac{x}{1-\frac{1}{1+r}}, \\
\frac{1}{1+r} \cdot \frac{x}{1-\frac{1}{1+r}} & =\frac{1}{1+r} \cdot \frac{x}{\frac{1+r}{1+r}-\frac{1}{1+r}}, \\
\frac{1}{1+r} \cdot \frac{x}{\frac{r}{1+r}} & =\frac{x}{r} .
\end{aligned}
$$

Ez alapján:

$$
\begin{aligned}
\frac{x}{0.05} & =400, \\
20 \cdot x & =400, \\
x & =20 .
\end{aligned}
$$

Vissza a feladathoz 
5. feladat: Az a kérdés, hogy hogyan lehet 1000 fontot jobban befektetni. A banki hozam $1000 \cdot r$. A gyárban úgy lehet befektetni, ha gépet veszünk a pénzből, így évi 30 fontot takarítunk meg. A gépvásárlás akkor nem éri meg, ha a banki hozam a nagyobb, azaz ha

$$
\begin{aligned}
1000 \cdot r & \geq 30, \\
r & \geq 0.03 .
\end{aligned}
$$

Vagyis legfeljebb 3\% lehet a kamatláb. Úgyis lehet gondolkozni, hogy minek van kisebb költsége: ha örökké fizetjük az évi 30 fontot, vagy ha egyszer fizetünk 1000 fontot? A gépvásárlás akkor nem éri meg, ha

$$
1000 \geq \frac{30}{r},
$$

ami a fenti egyenlőtlenséggel ekvivalens.

Vissza a feladathoz

\section{6. feladat:}

a. A kiadásból származó pénz itt örökjáradék, amely (a szöveg szerint) már ma is fizet. Ha csak egy év múlva fizetne, tudnánk használni az örökjáradék formulát a pénzáram jelenértékének kiszámítására:

$$
\frac{10000}{r}=\frac{10000}{0.05}=200000 .
$$

Sốt ezt most is tudjuk használni, hiszen csak annyi a különbség, hogy most azonnal kapunk 10000 fityinget, így a lakás kiadásából származó pénzáram jelenértéke:

$$
10000+200000=210000 .
$$

b. Ha egy lakásért 273000 fityinget lehet kapni, csak akkor nem éri meg eladni, ha a lakás kiadásából legalább ennyi pénzt lehet szerezni. Jelöljük az új éves albérleti díjat $x$-szel, ekkor

$$
273000=x+\frac{x}{r}=x+\frac{x}{0.05}=21 \cdot x,
$$

vagyis

$$
x=13000,
$$

az albérleti díjak évi 3000 fityinggel nőttek.

Vissza a feladathoz 
7. feladat: A nagyobb jelenértékú aktívát kell választani. Az arany jelenértéke, ha azonnal eladjuk, 795 rúpia. Ha jövőre adjuk el, $\frac{880}{1.1}$, ha két év múlva, akkor $\frac{965}{1.1^{2}}$, stb. Ezek közül a $\frac{880}{1.1}=800$ a legnagyobb. Ha nem szeretnénk minden jelenértéket kiszámolni, úgy is gondolkodhatunk, hogy mindig abba az eszközbe kell fektetni a pénzt, ami a nagyobb hozamot hoz. Az arany minden évben 85 rúpia hozamot hoz, a bankbetét a befektetett összeg 10\%-át. Ez alapján akkor fogjuk aranyból bankbetétbe átcsoportosítani vagyonunkat, ha vagyonunk $10 \%$-a nagyobb, mint 85 , azaz ha már több mint 850 rúpiáért el tudjuk adni az aranyat. Ezt először egy év után tudjuk megtenni, így akkor kell eladni az aranyat, így a jelenértéke 800 rúpia.

Az örökjáradék jelenértéke

$$
\frac{90}{0.1}=900
$$

lenne, ha először jövőre fizetne. De mivel már idén is fizet 90 rúpiát, a jelenérték

$$
90+900=990 .
$$

Ez alapján az örökjáradékot kell választani.

Vissza a feladathoz

8. feladat: Először is számoljuk ki, hogy jövơre mennyit ér egy hordó olaj. Egyensúlyban megegyezik a kereslet és a kínálat, azaz:

$$
\begin{aligned}
D(p) & =S(p), \\
\frac{2625}{p} & =25, \\
p & =105 .
\end{aligned}
$$

Ha idén $p$ dinárba kerül egy hordó olaj, és emellé még a 2 dinár tárolási díjat is ki kell fizetni, akkor az olajügylet hozama:

$$
\frac{105}{p+2}-1 \text {. }
$$

Mivel nincs arbitrázs, ez nem lehet nagyobb, ${ }^{1}$ mint a piaci kamatláb, azaz:

$$
\begin{aligned}
\frac{105}{p+2}-1 & \leq 5 \%=\frac{105}{100}-1 \\
100 & \leq p+2 \\
98 & \leq p .
\end{aligned}
$$

\footnotetext{
${ }^{1}$ Kisebb lehet, mivel a mai keresletet nem feltétlen tudom jövôre kitermelt olajjal kielégíteni.
} 
Egy hordó olaj idén tehát legalább 98 dinárba kerül.

Vissza a feladathoz

9. feladat: A vállalat annyit ér, mint jövedelemáramának jelenértéke. Ha ma hitelt veszünk fel, és a vállalat bevételeit, kiadásait mindig ugyanerre számlára utaljuk, akkor a hitelt éppen akkor tudjuk finanszírozni, ha nagysága a jövedelemáram jelenértéke. A számítást illetően talán az a legjobb, ha egyszerre próbáljuk megoldani a két feladatrészt. A jelölés rövidítése érdekében legyen $\alpha=6.82, \beta=2.42$. Továbbá jelöljük az $\frac{1}{1.1}$ diszkontfaktort $\delta$-val. Ekkor az a. és b. feladatrészek jövedelemáramainak jelenértéke:

$$
\begin{aligned}
& S_{a}=\alpha-\delta \cdot \beta+\delta^{2} \cdot \alpha-\delta^{3} \cdot \beta+\ldots, \\
& S_{b}=-\beta+\delta \cdot \alpha-\delta^{2} \cdot \beta+\delta^{3} \cdot \alpha-\ldots
\end{aligned}
$$

Ekkor:

$$
\delta \cdot S_{b}=-\delta \cdot \beta+\delta^{2} \cdot \alpha-\delta^{3} \cdot \beta+\delta^{4} \cdot \alpha-\ldots
$$

Ez egy $\alpha$ híján ugyanaz, mint $S_{a}$. Mivel $|\delta|<1$, a sorok konvergensek, így:

$$
S_{a}-\delta \cdot S_{b}=\alpha
$$

Hasonlóképpen:

$$
S_{b}-\delta \cdot S_{a}=-\beta .
$$

Ezeket az egyenlőségeket egyébként nem elképesztő matematikai ösztöneinkből kell megsejteni, hanem úgy, hogy gondolkodunk a pénzáramokról. Amikor idén van Marsutazás, a vállalat $S_{a}$ milliárd forintot ér. Ez két részből áll: idén kapunk $\alpha$ milliárd forintot, és van az ezutáni pénzáram jelenértéke. Ez utóbbi egy évvel későbbi pénzben mért értéke éppen a vállalat egy évvel későbbi pénzáramának egy évvel későbbi pénzben mért értéke, vagyis $S_{b}$. Így:

$$
S_{a}=\alpha+\frac{S_{b}}{1+r}
$$

avagy a diszkontfaktoros jelöléssel:

$$
S_{a}=\alpha+\delta \cdot S_{b}
$$

Ez ekvivalens a $(*)$ egyenlőséggel. A másik egyenlőséget is megkaphatjuk ugyanilyen logikával. 
Ezeket felhasználva:

$$
\begin{gathered}
\left(S_{a}-\delta \cdot S_{b}\right)+\left(\delta \cdot S_{b}-\delta^{2} \cdot S_{a}\right)=\alpha-\delta \cdot \beta, \\
S_{a}-\delta^{2} \cdot S_{a}=\alpha-\delta \cdot \beta \\
S_{a}=\frac{\alpha-\delta \cdot \beta}{1-\delta^{2}} .
\end{gathered}
$$

Ugyanígy:

$$
\begin{gathered}
\left(S_{b}-\delta \cdot S_{a}\right)+\left(\delta \cdot S_{a}-\delta^{2} \cdot S_{b}\right)=\delta \cdot \alpha-\beta, \\
S_{b}-\delta^{2} \cdot S_{b}=\delta \cdot \alpha-\beta, \\
S_{b}=\frac{\delta \cdot \alpha-\beta}{1-\delta^{2}} .
\end{gathered}
$$

Behelyettesítve a feladat adatait:

a.

$$
\begin{aligned}
S_{a} & =\frac{\alpha-\delta \cdot \beta}{1-\delta^{2}} \\
S_{a} & =\frac{6.82-\frac{2.42}{1.1}}{1-\frac{1}{1.1^{2}}}=26.62 .
\end{aligned}
$$

b.

$$
\begin{aligned}
S_{b} & =\frac{\delta \cdot \alpha-\beta}{1-\delta^{2}}, \\
S_{b} & =\frac{6.82}{1.1}-2.42 \\
1-\frac{1}{1.1^{2}} & =21.78 .
\end{aligned}
$$

Vagyis ha idén szállítanak turistákat, akkor 26.62 milliárd forint a Kft. jelenértéke, ha idén nem szállítanak turistákat, akkor pedig 21.78 milliárd forint.

Vissza a feladathoz 
A BIZONYTALANSÁG 
1. feladat: Ha Önnek mindegy, belevág-e a játékba vagy sem, akkor jelenlegi vagyona a játék biztos egyenértékese, másképpen jelenlegi vagyonának

$$
\sqrt{400}=20
$$

haszna megegyezik a játék várható hasznával.

A játéknak három kimenete van:

1. Nem nyer. Ennek valószínúsége: 0.5 . Ebben az esetben vagyona $400-144=$ 256;

2. Nyer, de lebukik. Ennek valószínúsége: $0.5 * 0.3=0.15$. Ebben az esetben vagyona: $400-144-B=256-B$, ahol B a büntetés;

3. Nyer, és nem bukik le. Ennek valószínúsége: $0.5 * 0.7=0.35$. Ebben az esetben vagyona: $400+500=900$.

A játék várható haszna ezekből:

$$
0.5 \sqrt{256}+0.15 \sqrt{256-B}+0.35 \sqrt{900} .
$$

Miután ennek egyenlőnek kell lennie 20-szal, a keresett büntetés értéke

$$
B=156 .
$$

Vissza a feladathoz

2. feladat: A sorsjegy rossz kimenet esetén 0 tallért fizet. Szerencsés esetben azonban 4 tallért. Barátom várható haszna, ha teljes vagyonáért megveszi ezt a sorsjegyet tôlem:

$$
\begin{aligned}
p u\left(x_{r}\right)+(1-p) u\left(x_{j}\right) & = \\
0.5 \cdot 0^{2}+0.5 \cdot 4^{2} & =8 .
\end{aligned}
$$

Ha nem veszi meg tőlem, akkor (várható) haszna:

$$
U(2)=2^{2}=4
$$

Számára tehát kedvezőbb (nagyobb várható haszonnal jár), ha a sorsjegyet megveszi tôlem.

Vissza a feladathoz 
3. feladat: Tegyük fel először, hogy Egon nem tör be. Ekkor biztos esemény az optimális ideig tartó munka. A feladat, ha a munkaidőt a $t$ szimbólummal jelöljük:

$$
\begin{aligned}
& \max U(m, 60-t), \\
& m=t,
\end{aligned}
$$

aminek a megoldása:

$$
t=30, \quad U^{*}=900 .
$$

(Feltettük, hogy a kamatláb zérus.)

a. Tegyük most fel, hogy betör. Ekkor, ha nem bukik le, akkor:

$$
m=40, \quad 60-t=60, \quad U^{*}=2400 .
$$

Ha lebukik, akkor a feladata a következő:

$$
\begin{gathered}
\max U(m, 40-t), \\
m=t,
\end{gathered}
$$

ennek megoldása:

$$
m=20, \quad t=20, \quad U^{*}=400 .
$$

A várható haszna:

$$
p * 2400+(1-p) 400,
$$

ezt kell összehasonlítani azzal az esettel, amikor becsületesen dolgozni kezd.

$$
p * 2400+(1-p) 400=900
$$

amiből:

$$
p=\frac{1}{4}
$$

b. Ha 90 ficcs lenne a bankban, akkor ebból csak az az eset változik, amikor betör és nem bukik le. Ekkor a haszna:

$$
90 * 60=5400 .
$$

Ezt behelyettesítve:

$$
p^{\prime} * 5400+\left(1-p^{\prime}\right) 400=900
$$

ebből a

$$
p^{\prime}=\frac{1}{10}
$$

valószínúséget kapjuk küszöbként.

Vissza a feladathoz 
4. feladat: Ha Béla dolgozik, akkor a várható jövedelme a biztos keresete. Ehhez a szokásos feladatot kell megoldania:

$$
\begin{gathered}
\max U(R, E), \\
w R+1 \cdot E=52 w .
\end{gathered}
$$

Az érintési feltétel:

$$
\frac{w}{1}=\frac{M U_{R}(R, E)}{M U_{E}(R, E)}=\frac{E}{R},
$$

ebből és a költségvetési egyenes egyenletéből:

$$
R=26 \text {. }
$$

Az ekkor megszerzett hasznosság:

$$
U(26,26 w)=26 * 26 w=676 w .
$$

Ha Béla nem dolgozik semmit, hanem a szerencsjátékot választja, akkor a várható jövedelme:

$$
E=0.25 X+0.75 \cdot 0=0.25 X
$$

Hasznossága ekkor:

$$
U(52, E)=13 X \text {. }
$$

Ha Bélának mindegy, melyik opciót választja, akkor a két hasznosság ugyanakkora:

$$
676 w=13 X
$$

amiből:

$$
X=\frac{676}{13} w=52 w
$$

Vissza a feladathoz

5. feladat: Tekintsük először a sorsjegy esetét! Ha nyer (ennek valószínúsége 50\%), akkor a vagyonának jelenértéke:

$$
(120-20)+300=400,
$$

ha veszít, akkor:

$$
(120-20)=100 .
$$

Várható hasznossága ezek után:

$$
0.5 \sqrt{400}+0.5 \sqrt{100}=15 .
$$


Most nézzük meg az örökjáradékot. Ez biztosan hozza a pénzt, számunkra most a jelenértéke érdekes:

$$
P V=\frac{15}{0.1}=150
$$

Vagyonának jelenértéke tehát:

$$
(120-50)+150=220 .
$$

A fogyasztó várható hasznossága ezek után:

$$
1 \sqrt{220}
$$

amiről tudjuk, hogy

$$
\sqrt{220}<15
$$

a. A fogyasztó ezért a sorsjegy megvásárlását választja, hiszen ha nem csinál semmit, akkor várható haszna:

$$
1 * \sqrt{120}
$$

és ez mind a két eddig kiszámított értéknél kisebb.

b. Annyit lenne hajlandó fizetni, ami mellett vagyona jelenértékének várható haszna éppen 15, azaz:

$$
1 \sqrt{(120-x)+150}=15 \text {. }
$$

Ennek megoldása:

$$
x=45 \text {. }
$$

Vissza a feladathoz

6. feladat: Ha az Ön számára mindegy, hogy részt vesz-e a szerencsejátékban vagy sem, akkor vagyonának haszna éppen egyenlő a szerencsejáték (lutri) várható hasznosságával, azaz:

$$
\sqrt{225}=p \sqrt{225+175}+(1-p) \sqrt{225-81} .
$$

a. Ebből:

$$
p=\frac{3}{8}=0.375
$$


b. A 44 garast csak akkor kell kifizetnie, ha a nyerési esélyét növelik, azaz ez a pénzösszeg csak a lutri kifizetéseit csökkenti. Ilyenkor a lutri várható haszna:

$$
0.5 \sqrt{225-44+175}+0.5 \sqrt{225-44-81} .
$$

Ennek kell nagyobbnak lennie, mint a mostani vagyonának a haszna, azaz azt kell ellenőriznünk, hogy a

$$
0.5 \sqrt{225-44+175}+0.5 \sqrt{225-44-81}>\sqrt{225}
$$

egyenlootlenség igaz-e? Ezt könnyen megtehetjük számítógép nélkül is akár:

$$
0.5 \sqrt{356}+0.5 \sqrt{100}>(?) \sqrt{225}
$$

átalakítva és átrendezve:

$$
\sqrt{356} \ngtr 20 .
$$

Azaz nem fizet ezért 44 garast, hanem inkább nem játszik vagy marad a kisebb nyerési esélynél.

Vissza a feladathoz

\section{7. feladat:}

a. Ha Nyuszika az 1. portfóliót választja, akkor biztos meglesz a 289 euró készpénze, és 50\% valószínúséggel ez további 672 euróval nő. Így vagyona egy hónap múlva 50\% valószínúséggel 289, 50\% valószínúséggel 961 euró. A várható érték az egyes kimenetelek valószínúségekkel súlyozott átlaga, vagyis:

$$
50 \% \cdot 289+50 \% \cdot 961=625 .
$$

Ha a 2. portfóliót választja, akkor 50\% $50 \%=25 \%$ valószínúséggel mindkét cég részvénye 336-336 eurót ér, így összértékük ismét 672 euró. 50\% $50 \%=25 \%$ valószínúséggel az $A$ cég részvénye 336 eurót, a $B$ cég részvénye 0 eurót ér, összértékük 336 euró. Ugyanúgy $50 \% \cdot 50 \%=25 \%$ valószínúséggel az $A$ cég részvénye 0 eurót, a $B$ cég részvénye 336 eurót ér, összértékük 336 euró. Végül $50 \% \cdot 50 \%=25 \%$ valószínúséggel mindkét cég részvénye $0-0$ eurót ér, így összértékük 0 euró. Bármelyik kimenetel valósul is meg, a vagyont még a 289 euró készpénz is kiegészíti. Így a vagyon egy hónap múlva $25 \%$ valószínúséggel $289+672=961$ euró, $50 \%$ valószínúséggel $289+336=625$ euró, $25 \%$ valószínúséggel $289+0=289$ euró. A várható érték:

$$
25 \% \cdot 289+50 \% \cdot 625+25 \% \cdot 961=625 .
$$

Ha a 3. portfóliót választja, akkor $50 \%$ valószínûséggel az $A$ cég részvénye 336 , a $C$ cég részvénye 0 eurót ér, így összértékük 336 euró. Ugyanígy 50\% valószínúséggel az 
$A$ cég részvénye 0, a $C$ cég részvénye 336 eurót ér, így összértékük ismét 336 euró. Ehhez jön még mindkét esetben a 289 euró készpénz, így a várható érték:

$$
50 \% \cdot 625+50 \% \cdot 625=625 .
$$

Vagyis a várható érték mindhárom esetben 625 euró.

b. A szöveg szerint ha Nyuszika vagyona egy hónap múlva $x$ euró, akkor az ehhez tartozó hasznossága $u(x)=\sqrt{x}$. Így az egyes kimenetelekhez tartozó hasznosságok:

$$
u(289)=\sqrt{289}=17, \quad u(625)=\sqrt{625}=25, \quad u(961)=\sqrt{961}=31 .
$$

Nyuszika várható hasznossága az egyes kimenetelekhez tartozó hasznosságok valószínûségekkel súlyozott átlaga. Az 1. portfólió mellett ez:

$$
E U(1 \text {. portfólió })=50 \% \cdot \sqrt{289}+50 \% \cdot \sqrt{961}=24 \text {. }
$$

A 2. portfólió mellett ez:

$$
E U(2 . \text { portfólió })=25 \% \cdot \sqrt{289}+50 \% \cdot \sqrt{625}+25 \% \cdot \sqrt{961}=24.5 .
$$

A 3. portfólió mellett ez:

$$
E U(3 \cdot \text { portfólió })=50 \% \cdot \sqrt{625}+50 \% \cdot \sqrt{625}=25 .
$$

Az egyes portfóliók adatait táblázatokban is összefoglaljuk, hátha valakinek segít. A táblázatok oszlopai a véletlen lehetséges kimeneteleihez, a 'világállapotokhoz' tartozó értékeket adják meg, illetve amennyiben az adott sorban ennek van értelme, a várható érték is szerepel a jobb oldali szélső oszlopban.

Az 1. portfólió:

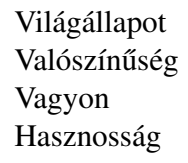

\begin{tabular}{|r|r|r|}
\multicolumn{1}{c}{$\mathrm{v}_{1}$} & \multicolumn{1}{c}{$\mathrm{v}_{2}$} & \multicolumn{1}{c|}{$\mathrm{E}$} \\
\hline $50 \%$ & $50 \%$ & \\
\hline 289 & 961 & 625 \\
\hline 17 & 31 & 24 \\
\hline
\end{tabular}

A 2. portfólió:

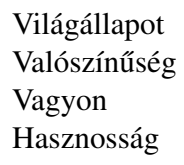

\begin{tabular}{|r|r|r|r||r|}
\multicolumn{1}{c}{$\mathrm{v}_{1}$} & \multicolumn{1}{c}{$\mathrm{v}_{2}$} & \multicolumn{1}{c}{$\mathrm{v}_{3}$} & \multicolumn{1}{c|}{$\mathrm{v}_{4}$} & $\mathrm{E}$ \\
\hline $25 \%$ & $25 \%$ & $25 \%$ & $25 \%$ & \\
\hline 289 & 625 & 625 & 961 & 625 \\
\hline 17 & 25 & 25 & 31 & 24.5 \\
\hline
\end{tabular}

A 3. portfólió:

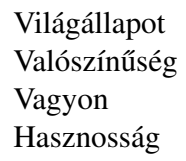

\begin{tabular}{|r|r||r|}
\multicolumn{1}{c}{$\mathrm{v}_{1}$} & \multicolumn{1}{c}{$\mathrm{v}_{2}$} & $\mathrm{E}$ \\
\hline $50 \%$ & $50 \%$ & \\
\hline 625 & 625 & 625 \\
\hline 25 & 25 & 25 \\
\hline
\end{tabular}


c. A harmadikat, hiszen ennek a legnagyobb a várható hasznossága. Ez abból is következik, hogy Nyuszika kockázatkerülő (vagyonra vonatkozó hasznosságfüggvénye konkáv), és mindhárom alternatívában ugyanakkora a vagyon várható értéke, 625. Mivel a 3. alternatíva mellett egyáltalán nincs kockázat, Nyuszika ezt fogja választani. Nagyobb várható értékért cserébe elfogadna némi kockázatot, de itt mindegyik alternatíva várható értéke ugyanakkora (625).

Vissza a feladathoz

\section{8. feladat:} is:

a. A várható érték az egyes kimenetelek valószínúségekkel súlyozott átlaga, vagy-

$$
10 \% \cdot 1+30 \% \cdot 2+30 \% \cdot 3+20 \% \cdot 4+10 \% \cdot 5=2.9
$$

b. A szöveg szerint, ha a javítóvizsgán kapott jegy $x$, akkor az ehhez tartozó hasznossága $u(x)=x^{2}$. Így az egyes kimenetelekhez tartozó hasznosságok:

$u(1)=1^{2}=1, \quad u(2)=2^{2}=4, \quad u(3)=3^{2}=9, \quad u(4)=4^{2}=16, \quad u(5)=5^{2}=25$.

A javító vizsga várható hasznossága az egyes kimenetelekhez tartozó hasznosságok valószínúségekkel súlyozott átlaga, vagyis:

$$
E U(\text { javítás })=10 \% \cdot 1^{2}+30 \% \cdot 2^{2}+30 \% \cdot 3^{2}+20 \% \cdot 4^{2}+10 \% \cdot 5^{2}=9.7 .
$$

Ha az eredeti jegye elégséges, akkor az eredeti jegy hasznossága $u(2)=2^{2}=4$. Ha nem megy javítani, ezt 100\% valószínúséggel megkapja, vagyis a nem javítás várható hasznossága:

$$
E U \text { (elégséges, nem javítás })=100 \% \cdot 2^{2}=4 \text {. }
$$

A javítás várható hasznossága nagyobb, mint a nem javításé, így itt elmegy javítani.

c. A nem javítás várható hasznossága ekkor:

$$
E U(\text { közepes, nem javítás })=100 \% \cdot 3^{2}=9 .
$$

Még ez is kisebb, mint a javítás várható értéke (9.7), úgyhogy közepes mellett is elmegy javítani.

d. A nem javítás várható hasznossága ekkor:

$$
E U(\text { jó, nem javítás })=100 \% \cdot 4^{2}=16 .
$$

Ez már nagyobb, mint a javítás várható hasznossága (9.7), úgyhogy jó mellett nem megy el javítani. 
e. Jelöljük a biztos egyenértékest $C E$-vel, az angol certainty equivalent kifejezés rövidítéseként. Ez az a biztos jegy, ami pont ugyanolyan hasznos, mint a javítóvizsga bizonytalan jegye, vagyis:

$$
\begin{aligned}
E U(C E) & =E U(\text { javítás }), \\
1 \cdot C E^{2} & =9.7, \\
C E & =\sqrt{9.7} \approx 3.114 .
\end{aligned}
$$

Persze ilyen jegy nincs, de ha lenne, ez lenne a legkisebb, amit elfogad javítás helyett. Ha ennél rosszabbat kap, inkább elmegy javítani. És pont ezt láttuk a b., c., d. részfeladatokban. Illetve azt is látjuk, hogy a biztos egyenértékes az a. feladatban kiszámolt várható érték fölött van, vagyis a várható értéknél jobb jegyet fogadna csak el. Ez azért van, mert Chirrut kockázatkedvelő.

Vissza a feladathoz

\section{9. feladat:}

a. Robin várható hasznossága, ha dulakodni kezdenek:

$$
0.6 \cdot \sqrt{25+200}+0.4 \cdot \sqrt{0}=0.6 \cdot 15+0.4 \cdot 0=9 .
$$

Ha elfogadja az ajánlatot:

$$
1 \cdot \sqrt{25+75}=10 .
$$

Jobban megéri a békesség, úgy nagyobb a várható hasznosság.

b. Várható hasznosságok az új esetben (Robinnál 100 arany van):

$$
0.8 \cdot \sqrt{100+300}+0.2 \cdot \sqrt{0}=0.8 \cdot 20+0.2 \cdot 0=16 .
$$

Mekkora biztos ajánlattal érhető el ekkora a várható hasznosság?

$$
\begin{aligned}
1 \cdot \sqrt{100+x} & =16, \\
100+x & =256, \\
x & =156 .
\end{aligned}
$$

Vissza a feladathoz 


\section{0. feladat:}

a. Jelölje $\pi$ annak a valószínúségét, hogy ismerősöm nyeri a fogadást. A várható hasznossága, ha nem fújjuk le a fogadást:

$$
(1-\pi) \cdot \sqrt{50+50}+\pi \cdot \sqrt{50-50}=10 \cdot(1-\pi) .
$$

Ha elfogadom az ajánlatot:

$$
1 \cdot \sqrt{50-14}=6 .
$$

Ez csak akkor éri meg neki, ha

$$
\begin{aligned}
6 & \geq 10 \cdot(1-\pi), \\
10 \cdot \pi & \geq 4, \\
\pi & \geq 0.4 .
\end{aligned}
$$

b. Az én várható hasznosságom:

$$
0.8 \cdot \sqrt{50+50}+0.2 \cdot \sqrt{50-50}=8 .
$$

Ha elfogadom az ajánlatot:

$$
1 \cdot \sqrt{50+14}=8 .
$$

Mindegy nekem, hogy elfogadom-e az ajánlatot.

Vissza a feladathoz

11. feladat: Jelöljük az eredeti vagyont $m$-mel, a megvásárolt randokat $x$-szel! Ekkor a vagyon az első világállapotban (abban az esetben, ha nő a rand árfolyama):

$$
m-25 \cdot x+26 \cdot x=m+x .
$$

Hasonlóképp a vagyon a második világállapotban (abban az esetben, ha csökken a rand árfolyama):

$$
m-25 \cdot x+24 \cdot x=m-x
$$

A hasznosságfüggvény:

$$
51 \% \cdot \sqrt{m+x}+49 \% \cdot \sqrt{m-x} .
$$

Fern ezt maximalizálja $x$ szerint (mivel arról dönt, hogy mennyi randot vegyen). Ekkor:

$$
51 \% \cdot \frac{1}{2 \cdot \sqrt{m+x}}+49 \% \cdot \frac{-1}{2 \cdot \sqrt{m-x}}=0 .
$$


Ezt átrendezve:

$$
\begin{aligned}
51 \% \cdot \frac{1}{2 \cdot \sqrt{m+x}} & =49 \% \cdot \frac{1}{2 \cdot \sqrt{m-x}} \\
51^{2} \cdot(m-x) & =49^{2} \cdot(m+x) .
\end{aligned}
$$

Mivel Fern 100 randot vett, ezért:

$$
\begin{aligned}
51^{2} \cdot(m-100) & =49^{2} \cdot(m+100), \\
200 \cdot m & =500200 \\
m & =2501 .
\end{aligned}
$$

Vissza a feladathoz

\section{2. feladat:}

a. Mondjuk, hogy Marco $d$ részvényt ad el holnap, a többit ma. Jelölje $x$ Marco vagyonát abban az esetben, ha a felvásárlás sikeres, y pedig akkor, ha a felvásárlás sikertelen. A szöveg szerint:

$$
x=60+d \cdot 15+(300-d) \cdot 6=1860+d \cdot 9 .
$$

Hasonlóképpen:

$$
y=60+d \cdot 5+(300-d) \cdot 6=1860-d .
$$

A $d$ változóról Marco dönt, így az általa elérhetô vagyonállapotokat az $(1860,1860)$ ponton áthaladó $-\frac{1}{9}$ meredekségû egyenes határolja, ez most a költségvetési egyenes. Ha nem ,látjuk” a meredekséget:

$$
\begin{aligned}
& x=1860+d \cdot 9 \\
& d=\frac{x-1860}{9}=\frac{1}{9} \cdot x-\frac{1860}{9}, \\
& y=1860-d=1860+\frac{1860}{9}-\frac{1}{9} \cdot x .
\end{aligned}
$$

Marco várható hasznosságfüggvénye:

$$
U(x, y)=\frac{1}{10} \cdot \ln x+\frac{9}{10} \cdot \ln y .
$$


Az MRS-feltétel alapján optimumban a közömbösségi görbe meredeksége megegyezik a költségvetési korlát meredekségével, így:

$$
\begin{aligned}
\left|\operatorname{MRS}\left(x^{*}, y^{*}\right)\right| & =\frac{10 \%}{90 \%} \cdot \frac{y^{*}}{x^{*}}=\frac{1}{9}, \\
x^{*} & =y^{*} .
\end{aligned}
$$

Ezek szerint vagyona nem függ a holnapi történésektől, és ez csak akkor lehet, ha minden részvényét még ma eladja. Algebrailag: mivel

$$
x=1860+d \cdot 9 \quad y=1860-d,
$$

csak úgy lehetséges, hogy $x^{*}=y^{*}$, ha $d^{*}=0$. Ekkor $x^{*}=1860$, ennyi pénze lesz sikeres felvásárlás esetén.

Egyébként a költségvetési korlát kiszámításánál észrevehettük volna, hogy Marco úgy tud pénzt mozgatni az egyes világállapotok között, hogy a vagyona várható értéke nem változik. (Az árarány egyenlő a valószínúségek arányával.) Ez a fair biztosításnak felel meg. Mivel Marco kockázatkerülő, teljes biztosítást köt, azaz úgy csoportosítja pénzügyi eszközeit, hogy minden világállapotban ugyanannyi pénze legyen. Ez most annyit tesz, hogy nem lesz kockázatos eszköze, azaz minden részvényt még ma elad.

b. Ahogy az elôző pontban már láttuk, $d^{*}=0$, holnap egy részvényt sem ad el, mindet ma értékesíti.

Vissza a feladathoz

\section{3. feladat:}

a. Jelöljük $x$-szel Lord Keynes vagyonát a franciaellenes koalíció győzelme esetén, $y$-nal pedig a francia győzelem esetén. Hasznosságfüggvénye:

$$
U(x, y)=\frac{1}{2} \cdot \sqrt{x}+\frac{1}{2} \cdot \sqrt{y} .
$$

Franciaellenes koalíció esetén 1 fontnyi kötvény 3 fontot ér. Ez azt jelenti, hogy Lord Keynes egyharmad fontért tud venni egy olyan fontot, amit csak koalíciós győzelem esetén kap meg, azaz $p_{x}=\frac{1}{3}$. Ugyanakkor a biztos font az egy olyan jószágkosár, amiben $x$ és $y$ jószágból is pontosan 1 van, mivel egy biztos font mindkét világállapotban (francia győzelem esetén is, koalíciós győzelem esetén is) 1 fontot ér. Mivel a biztos font a pénz mértékegysége, ára értelemszerúen 1. Ez meg kell hogy egyezzen egy francia és egy koalíciós győzelem esetén megkapott font árainak összegével, hiszen 
ugyanarról a jószágról beszélünk. Ez alapján egy francia győzelem esetén megkapott font ára

$$
p_{y}=1-p_{x}=1-\frac{1}{3}=\frac{2}{3} .
$$

Ha nem vásárol kötvényt, Lord Keynesnek mindkét világállapotban 50 fontja van, így a költségvetési korlát:

$$
\begin{aligned}
p_{x} \cdot \omega_{x}+p_{y} \cdot \omega_{y} & =p_{x} \cdot x^{*}+p_{y} \cdot y^{*} \\
\frac{1}{3} \cdot 50+\frac{2}{3} \cdot 50 & =50=\frac{1}{3} \cdot x^{*}+\frac{2}{3} \cdot y^{*} .
\end{aligned}
$$

Az MRS-feltételből:

$$
\begin{gathered}
\left|\operatorname{MRS}\left(x^{*}, y^{*}\right)\right|=\frac{\frac{\partial\left(\frac{1}{2} \cdot \sqrt{x}+\frac{1}{2} \cdot \sqrt{y}\right)}{\partial x}}{\frac{\partial\left(\frac{1}{2} \cdot \sqrt{x}+\frac{1}{2} \cdot \sqrt{y}\right)}{\partial y}}=\frac{p_{x}}{p_{y}}, \\
\frac{\frac{1}{2} \cdot \frac{1}{2 \cdot \sqrt{x^{*}}}}{\frac{1}{2} \cdot \frac{1}{2 \cdot \sqrt{y^{*}}}}=\frac{\frac{1}{3}}{\frac{2}{3}}, \\
\frac{\sqrt{y^{*}}}{\sqrt{x^{*}}}=\frac{1}{2}, \\
y^{*}=\frac{1}{4} \cdot x^{*} .
\end{gathered}
$$

Ezt behelyettesítve a költségvetési korlátba:

$$
\begin{gathered}
50=\frac{1}{3} \cdot x^{*}+\frac{2}{3} \cdot y^{*}, \\
50=\frac{1}{3} \cdot x^{*}+\frac{2}{3} \cdot \frac{1}{4} \cdot x^{*}, \\
50=\frac{1}{2} \cdot x^{*}, \\
x^{*}=100 y^{*}=\frac{1}{4} \cdot x^{*}=25 .
\end{gathered}
$$

A kötvények francia győzelem esetén értéktelenek, ekkor vagyona $\left(y^{*}\right)$ csak készpénzből áll, azaz 25 fontot tartott meg, a többi 50-25=25 fontból vett kötvényeket. 
És valóban, francia vereség esetén a vagyona 25 font készpénz és 25 darab 3 font értékú kötvény, azaz:

$$
x^{*}=25+25 \cdot 3=100 \text {. }
$$

b. Ha már előre tudja a csata kimenetelét, csak francia vereség esetén fog kötvényt vásárolni, ekkor viszont minden pénzéből. Azaz vagyona, ha nyernek a franciák,

$$
50-14=36
$$

font (kifizette az információt, kötvényt pedig nem vett, hiszen értéktelen), míg ha vesztenek a franciák akkor vagyona

$$
(50-14) \cdot 3=108
$$

font (kifizette az információt, és még 1 fontos áron vásárolt kötvényeket, amelyek ára 3 fontra nôtt, miután a többiek is megtudták, hogy vesztettek a franciák). A kérdés az, hogy ez nagyobb várható hasznosságot ad neki, mintha az információ nélkül spekulál? A világállapotok valószínúsége mindenképpen 50-50\%, a különbség annyi, hogy ha előre tudja az információt, más döntést hoz. Hogy ez megéri-e, az a várható hasznosságokon múlik.

Információ nélkül:

$$
\frac{1}{2} \cdot \sqrt{100}+\frac{1}{2} \cdot \sqrt{25}=7.5
$$

Információval:

$$
\frac{1}{2} \cdot \sqrt{36}+\frac{1}{2} \cdot \sqrt{108} \approx 8.196
$$

Tehát megéri fizetni az információért.

Vissza a feladathoz 
TECHNOLÓGIA 


\section{1. feladat:}

a. A technikai helyettesítési határarány csak az isoquant adott pontbeli meredekségétől függ, és egyenlő a határhasznok hányadosának ellentettjével. Ebből (az analógiát felhasználva) már látszik, hogy tetszőleges monoton pozitív transzformációt alkalmazva a termelési függvényre, az $\operatorname{MRTS}\left(x_{1}, x_{2}\right)$ nem változik, mert a transzformáció mint külső függvény deriváltja mind a számlálóban, mind a nevezőben szerepel. Ezekből az

$$
y=\left(x_{1}^{a} x_{2}^{a}\right)^{2}
$$

termelési függvény

$$
\frac{1}{2 a} \text { - adik }
$$

hatványát véve, valamint tudva, hogy az

$$
x_{1} x_{2}
$$

alakú termelési függvényhez az

$$
\operatorname{MRTS}\left(x_{1}, x_{2}\right)=-\frac{x_{2}}{x_{1}}
$$

alakú technikai helyettesítési határarány tartozik, kapjuk, hogy nem létezik olyan pozitív $a$ konstans, amelyekre a technikai helyettesítési határarány értékének abszolút értéke növekvő, hiszen az isoquant egy hiperbola.

b. A mérethozadék növekvő, ha $t>1$ esetén az

$$
y=\left(x_{1}^{a} x_{2}^{a}\right)^{2}
$$

termelési függvényre:

$$
t y<\left((t x)_{1}^{a}(t x)_{2}^{a}\right)^{2} .
$$

Elvégezve a jobb oldalon kijelölt múveleteket és kiemelve:

$$
t y<t^{(2 a)^{2}}\left(x_{1}^{a} x_{2}^{a}\right)^{2}=t^{(2 a)^{2}} y
$$

ami akkor és csak akkor igaz, ha:

$$
1<(2 a)^{2}
$$

amiből:

$$
a>\frac{1}{2}
$$

Vissza a feladathoz 


\section{2. feladat:}

a. A technikai helyettesítési határarány az

$$
y=x_{1}^{a}+x_{2}^{a}
$$

isoquant adott pontbeli meredekségétől függ, és egyenlő a határhasznok hányadosának ellentettjével. Ebből:

$$
\left|\operatorname{MRTS}\left(x_{1}, x_{2}\right)\right|=\frac{M U_{1}\left(x_{1}, x_{2}\right)}{M U_{1}\left(x_{1}, x_{2}\right)}=\frac{a x_{1}^{a-1}}{a x_{2}^{a-1}}=\frac{x_{1}^{a-1}}{x_{2}^{a-1}} .
$$

A technikai helyettesítési határarányt akkor mondjuk csökkenőnek, ha abszolút értéke $x_{1}$-ben csökkenő, azaz a fenti kifejezés parciális deriváltja $x_{1}$-ben negatív. Ez a parciális derivált:

$$
\frac{\left|\partial \operatorname{MRTS}\left(x_{1}, x_{2}\right)\right|}{\partial x_{1}}=(a-1) \frac{x_{1}^{a-2}}{x_{2}^{a-1}},
$$

ami akkor negatív, ha:

$$
(0<) a<1
$$

b. A mérethozadék növekvő, ha $t>1$ esetén az

$$
y=x_{1}^{a}+x_{2}^{a}
$$

termelési függvényre:

$$
t y<\left(t x_{1}\right)^{a}+\left(t x_{2}\right)^{a} .
$$

Elvégezve a jobb oldalon kijelölt múveleteket és kiemelve:

$$
t y<t^{a}\left(x_{1}^{a}+x_{2}^{a}\right)=t^{a} y,
$$

ami akkor és csak akkor igaz, ha:

$$
a>1 \text {. }
$$

Vissza a feladathoz

\section{3. feladat:}

a. Minden $t>1$ valós számra:

$$
t y<\left((t k)^{\frac{1}{2}}+(t l)^{\frac{1}{2}}\right)^{3}=t^{\frac{3}{2}}\left(k^{\frac{1}{2}}+l^{\frac{1}{2}}\right)^{3}=t^{\frac{3}{2}} y, \quad \text { tehát NÖVEKVŐ. }
$$


b. Minden $t>1$ valós számra:

$$
t y>\left((t k)^{\frac{1}{3}}+(t l)^{\frac{1}{3}}\right)^{2}=t^{\frac{2}{3}}\left(k^{\frac{1}{3}}+l^{\frac{1}{3}}\right)^{2}=t^{\frac{2}{3}} y, \quad \text { tehát CSÖKKENŐ. }
$$

c. Minden $t>1$ valós számra:

$$
\text { ty }>(2(t k)+3(t l))^{\frac{1}{2}}=t^{\frac{1}{2}}(2 k+3 l)^{3}=t^{\frac{1}{2}} y, \quad \text { tehát CSÖKKENŐ. }
$$

Vissza a feladathoz

4. feladat: A termelési függvény:

$$
f(k, d, b)=\min (k ; d+b) .
$$

A $(k, d, b)=(10,8,4)$ készletpont kis környezetében a termelési függvény:

$$
f(k, d, b)=\min (k ; d+b)=k,
$$

vagyis ha az erőforrásmennyiségek csak kis mértékben változnak, akkor a kifli a szúk keresztmetszet, ez határozza meg az elkészíthető hotdogok számát. Ez alapján:

a.

$$
M P_{k}(10,8,4)=\frac{\partial f(10,8,4)}{\partial k}=\left.\frac{\mathrm{d} k}{\mathrm{~d} k}\right|_{(k, d, b)=(10,8,4)}=1 .
$$

A matematikai jelölés magyarázata:

$\mathrm{Ez}$

$$
\left.f(x)\right|_{x=10}
$$

azt jelzi, hogy az $f(x)$ függvény által az $x=10$ helyen vett értéket vesszük, azaz $f(10)$ t. Deriválásnál lehet hasznos, mivel

$$
\left.\frac{\mathrm{d} x^{2}}{\mathrm{~d} x}\right|_{x=10}=\left.2 x\right|_{x=10}=20 \neq \frac{\mathrm{d} 10^{2}}{\mathrm{~d} x}=0 .
$$

b.

$$
M P_{d}(10,8,4)=\frac{\partial f(10,8,4)}{\partial d}=\left.\frac{\mathrm{d} k}{\mathrm{~d} d}\right|_{(k, d, b)=(10,8,4)}=0 .
$$

Vagyis hiába kapok több disznóhúst, nem tudok több hotdogot csinálni, nincs elég kifli.

c.

$$
M P_{b}(10,8,4)=\frac{\partial f(10,8,4)}{\partial b}=\left.\frac{\mathrm{d} k}{\mathrm{~d} b}\right|_{(k, d, b)=(10,8,4)}=0
$$


d.

$$
\left|\operatorname{MRTS}_{k d}(10,8,4)\right|=\frac{M P_{k}(10,8,4)}{M P_{d}(10,8,4)} .
$$

Mivel $\operatorname{MP}_{d}(10,8,4)=0$, ezért a technikai helyettesítési határarány nem értelmezhető. Ez nem meglepó, mivel ilyen gyártási függvény mellett nagyon sok disznóhússal sem tudom helyettesíteni a kiflit a hotdogban.

e.

$$
\left|\operatorname{MRTS}_{d b}(10,8,4)\right|=\frac{M P_{d}(10,8,4)}{M P_{b}(10,8,4)} .
$$

Mivel $M P_{b}(10,8,4)=0$, ezért a technikai helyettesítési határarány nem értelmezhetô. Ez már valamennyire meglepő, mivel a kétféle hús egymás $1-1$ arányú tökéletes helyettesítője. A probléma abban rejlik, hogy éppen mindkettőből „felesleg” van.

f. $\quad \mathrm{A}(k, d, b)=(10,6,4)$ készletpont kis környezetében az

$$
f(k, d, b)=\min (k ; d+b)
$$

termelési függvényt nem lehet egyszerúsíteni. A határtermékek nem léteznek, mivel ebben a pontban a termelési függvény egyik tényező szerint sem differenciálható. Közgazdasági érv, hogy bármelyik input növekedése hasztalan lenne (továbbra is 10 hotdogot lehetne csinálni), de csökkenése káros (valami hiányozna 10 hotdoghoz), ezért ebben a pontban a határtermék, ami egyszerre írja le az input növekedésének és csökkenésének hatását, nem létezik.

Vissza a feladathoz 


\section{PROFITMAXIMALIZÁLÁS}


1. feladat: A megadott és rögzített akácfamennyiség miatt a Rózsa Sándor Bt. rövid távú termelési függvénye:

$$
y=15+\sqrt{b} .
$$

Az e mellett a feltétel mellett maximalizálandó célfüggvény:

$$
\max _{m} 20 y-2 b
$$

a. Ezekből az optimális

$$
p M P_{b}(\bar{a}, b)=w_{b}
$$

tényezőkeresleti függvény:

$$
20 * \frac{1}{2 \sqrt{b}}=2,
$$

amiből:

$$
b=25 \text {. }
$$

b. Ezt az értéket visszahelyettesítjük a rövid távú termelési függvénybe:

$$
y=15+\sqrt{b}=15+5=20 .
$$

c. A profit ezek után:

$$
\pi=20 * 20-2 * 25=350
$$

Vissza a feladathoz

2. feladat: A profitmaximalizálási feladat:

$$
\begin{aligned}
& \max \left\{p y-5 x_{1}-6 x_{2}\right\}, \\
& y=\left(\min \left\{5 x_{1}, 3 x_{2}\right\}\right)^{1 / 3} .
\end{aligned}
$$

A feladat feltétele nyilvánvalóan egyenlőségre teljesül, hiszen biztosan pazarlás több inputot felhasználni, mint amennyi feltétlenül szükséges, amiből:

$$
y^{3}=\min \left\{5 x_{1}, 3 x_{2}\right\} .
$$

Ugyancsak tudjuk, hogy a jobb oldalon a minimumban szereplő két érték is egyenlő egymással:

$$
y^{3}=5 x_{1}=3 x_{2} .
$$


Ebből az következik, hogy egyrészt mind a két inputra szükség van az adott rögzített arányban, másrészt, hogy y termeléshez

$$
x_{1}=\frac{y^{3}}{5}
$$

egység első, illetve

$$
x_{2}=\frac{y^{3}}{3}
$$

egység második inputra van szükség. Visszahelyettesítve a célfüggvénybe kapjuk a feltétel nélküli maximalizálási feladatot:

$$
\max \left\{p y-5 x_{1}-6 x_{2}\right\}=\max \left\{p y-5 \frac{y^{3}}{5}-6 \frac{y^{3}}{3}\right\} .
$$

Ennek maximumához csak a deriváltját kell zérussal egyenlővé tenni:

$$
p-3 y^{2}-6 y^{2}=0
$$

amiből:

$$
p=9 y^{2}
$$

Ebből kapjuk a kínálati függvényt:

$$
y=\sqrt{\frac{p}{9}}=\frac{\sqrt{p}}{3} .
$$

Vissza a feladathoz

3. feladat: Profitmaximalizálási feladat általánosan:

$$
\max _{y, x} \Pi=p \cdot y-w \cdot x
$$

Feltéve hogy: $\quad f(x) \geq y$.

Behelyettesítve a feladat konkrét adatait:

$$
\begin{aligned}
\max _{y, x} \Pi & =6 \cdot y-3 \cdot x, \\
\sqrt{x} & \geq y .
\end{aligned}
$$

Mivel az output (termék) és az input (nyersanyag) ára is pozitív, a vállalat a lehető legtöbb bútort fogja előállítani a lehető legkevesebb fa felhasználásával, azaz optimumban:

$$
\sqrt{x}=y
$$


Megoldás szélsőérték-számítással:

$$
\begin{aligned}
x & =y^{2}, \\
\Pi & =6 \cdot y-3 \cdot y^{2}, \\
\frac{\mathrm{d} \Pi}{\mathrm{d} y} & =6-6 \cdot y=0, \\
y & =1 .
\end{aligned}
$$

Megoldás mikróökonómiai fogalmakkal:

Ha a versenyzői vállalat pozitív mennyiségben használ fel fát a bútorok előállítása során, akkor optimumban megegyezik a fa határtermékének az értéke és a fa egységára, vagyis:

$$
p \cdot M P(x)=w .
$$

Ebből:

$$
\begin{aligned}
p \cdot M P(x) & =w, \\
6 \cdot \frac{\mathrm{d} \sqrt{x}}{\mathrm{~d} x} & =3, \\
\frac{6}{2 \sqrt{x}} & =3, \\
1 & =x, \\
y & =\sqrt{x}=1 .
\end{aligned}
$$

Vissza a feladathoz

\section{4. feladat:}

a. A vállalat a profitját maximalizálja, így optimumfeladata:

$$
\max _{K, L}\left\{3 \cdot 4 \cdot K^{\frac{1}{4}} \cdot L^{\frac{1}{2}}-2 \cdot K-1 \cdot L\right\} .
$$


Ennek az elsőrendû optimumfeltételei:

$$
\begin{aligned}
& 3 \cdot \frac{\partial f(K, L)}{\partial K}-2=0 \\
& 3 \cdot \frac{\partial f(K, L)}{\partial L}-1=0 .
\end{aligned}
$$

A deriválásokat elvégezve és a tényezőárakat a jobb oldalra tolva:

$$
\begin{aligned}
& 3 \cdot 4 \cdot \frac{1}{4} \cdot K^{-\frac{3}{4}} \cdot L^{\frac{1}{2}}=2, \\
& 3 \cdot 4 \cdot \frac{1}{2} \cdot K^{\frac{1}{4}} \cdot L^{-\frac{1}{2}}=1 .
\end{aligned}
$$

Ez elég bonyolultnak tûnik, de az elsố egyenletet elosztva a másodikkal:

$$
\begin{gathered}
\frac{4 \cdot \frac{1}{4} \cdot K^{-\frac{3}{4}} \cdot L^{\frac{1}{2}}}{4 \cdot \frac{1}{2} \cdot K^{\frac{1}{4}} \cdot L^{-\frac{1}{2}}}=\frac{2}{1}, \\
\frac{1}{2} \cdot \frac{L}{K}=2,
\end{gathered}
$$

avagy

$$
L=4 \cdot K \text {. }
$$

Ezt visszaírva valamelyik (mondjuk az elsô) optimumfeltételbe:

$$
\begin{aligned}
3 \cdot 4 \cdot \frac{1}{4} \cdot K^{-\frac{3}{4}} \cdot L^{\frac{1}{2}} & =2 \\
3 \cdot K^{-\frac{3}{4}} \cdot\left(4 \cdot K^{\frac{1}{2}}\right. & =2, \\
6 \cdot K^{-\frac{1}{4}} & =2, \\
3 & =K^{\frac{1}{4}} .
\end{aligned}
$$

Ebből:

$$
K=81, \quad L=324
$$

a kibocsátás:

$$
y=4 \cdot 3 \cdot 18=216,
$$

a profit pedig:

$$
\Pi=p \cdot y-r \cdot K-w \cdot L=3 \cdot 216-2 \cdot 81-1 \cdot 324=162 .
$$


b. A technikai helyettesítési határarány az egyenlőtermék-görbe meredekségét írja le:

$$
\operatorname{MRTS}(K, L)=-\frac{M P_{1}(K, L)}{M P_{2}(K, L)} .
$$

Ha mindkét tényező felhasználása pozitív (az előző pontban leírtak szerint most az), akkor profitmaximumban:

$$
\begin{aligned}
& p \cdot M P_{1}(K, L)=r, \\
& p \cdot M P_{2}(K, L)=w .
\end{aligned}
$$

Így a két egyenlet arányából:

$$
\begin{aligned}
\frac{p \cdot M P_{1}(K, L)}{p \cdot M P_{2}(K, L)} & =\frac{r}{w}, \\
\frac{M P_{1}(K, L)}{M P_{2}(K, L)} & =\frac{r}{w} .
\end{aligned}
$$

De ott a bal oldalon szereplő tört épp a technikai helyettesítési határarány abszolút értéke. Jobb oldalon pedig a tényezóárak aránya $2 / 1$, így az optimumban -2 a technikai helyettesítési határarány.

c. Az a. pontban lévő számítások alapján:

$$
\begin{aligned}
|\operatorname{MRTS}(K, L)| & =\frac{r}{w}, \\
\frac{1}{2} \cdot \frac{L}{K} & =\frac{r}{w}, \\
L & =K \cdot 2 \cdot \frac{r}{w},
\end{aligned}
$$

illetve:

$$
\begin{gathered}
p \cdot M P_{1}(K, L)=r, \\
p \cdot K^{-\frac{3}{4}} \cdot L^{\frac{1}{2}}=r .
\end{gathered}
$$


Ebbe az egyenletbe behelyettesítve a korábban $L$-re kapott összefüggést:

$$
\begin{gathered}
p \cdot K^{-\frac{3}{4} \cdot\left(K \cdot 2 \cdot \frac{r}{w}\right)^{\frac{1}{2}}}=r, \\
p \cdot\left(2 \cdot \frac{r}{w}\right)^{\frac{1}{2}} \cdot K^{-\frac{1}{4}}=r, \\
p \cdot\left(2 \cdot \frac{1}{r \cdot w}\right)^{\frac{1}{2}}=K^{\frac{1}{4}}, \\
\left(\frac{p^{2} \cdot 4}{r \cdot w}\right)^{2}=K .
\end{gathered}
$$

Vissza a feladathoz

\section{5. feladat:}

a. A szöveg szerint $y$ probléma esetén

$$
i=\frac{y^{2}}{2}, \quad t=y^{2}
$$

inputra van szükség, vagyis:

$$
\sqrt{2 \cdot i}=y, \quad \sqrt{t}=y .
$$

Mivel nincs helyettesítés, ha bármelyik input mennyiségét csökkentenénk, nem tudnánk $y$ problémát megoldani. Így a termelési függvény:

$$
f(i, t)=\sqrt{\min (2 \cdot i ; t)} .
$$

b. $\mathrm{Az}(i, t)=(10,10)$ pont kis környezetében

$$
2 \cdot i>t
$$

így a termelési függvény ebben a környezetben:

$$
f(i, t)=\sqrt{\min (2 \cdot i ; t)}=t .
$$

Ez alapján:

$$
M P_{1}(10,10)=\frac{\partial f(10,10)}{\partial i}=\left.\frac{\mathrm{d} t}{\mathrm{~d} i}\right|_{(10,10)}=0
$$


c. A vállalat profitmaximum-feladata:

$$
\begin{array}{ll}
\max _{i, t, y} & \{8 \cdot y-2 \cdot i-1 \cdot t\}, \\
\text { f.t.h. } & \sqrt{\min (2 \cdot i ; t)} \geq y .
\end{array}
$$

Optimumban:

$$
\begin{aligned}
& y^{*}=\sqrt{2 \cdot i^{*}}=\sqrt{t^{*}}, \\
& i^{*}=\frac{y^{* 2}}{2}, \quad t^{*}=y^{* 2} .
\end{aligned}
$$

Ezt behelyettesítve a profitot leíró kifejezésbe:

$$
\begin{aligned}
& \Pi=8 \cdot y^{*}-2 \cdot i^{*}-1 \cdot t^{*}, \\
& \Pi=8 \cdot y^{*}-y^{* 2}-y^{* 2} .
\end{aligned}
$$

Vagyis $y$ optimális szintje minden mást meghatároz. De azt, hogy mi $y^{*}$, még ki kell számolnunk. Optimumban:

$$
\begin{aligned}
\frac{\mathrm{d} \Pi}{\mathrm{d} y} & =0, \\
8-4 \cdot y^{*} & =0, \\
2 & =y^{*} .
\end{aligned}
$$

Ebből az optimális profit:

$$
\begin{aligned}
& \Pi=8 \cdot y^{*}-2 \cdot y^{* 2}, \\
& \Pi=16-8=8 .
\end{aligned}
$$


d. A c. ponthoz hasonlóan profitmaximumban:

$$
\begin{gathered}
\Pi\left(p, w_{i}\right)=p \cdot y-w_{i} \cdot i-1 \cdot t, \\
\Pi\left(p, w_{i}\right)=p \cdot y-w_{i} \cdot y^{2}-y^{2}, \\
\frac{\mathrm{d} \Pi}{\mathrm{d} y}\left(p, w_{i}\right)=0, \\
p-2 \cdot w_{i} \cdot y^{*}-2 \cdot y^{*}=0, \\
y^{*}\left(p, w_{i}\right)=\frac{p}{2 \cdot w_{i}+2}, \\
i^{*}\left(p, w_{i}\right)=\frac{y^{* 2}}{2}, \\
\frac{p^{2}}{\left.2 \cdot w_{i}+2\right)^{2}} \\
i^{*}\left(p, w_{i}\right)=\frac{p^{2}}{2 \cdot\left(2+w_{i}\right)^{2}} .
\end{gathered}
$$

Vissza a feladathoz

\section{6. feladat:}

a. A vállalat eredetileg $K=81$ tôkét, és $L=324$ egység munkaerőt akart alkalmazni. A megváltozott árak mellett azonban nem biztos, hogy ez a legjobb. Rövid távon csak a munkaerőrôl dönthetnek, így a gyár optimumfeladata:

$$
\max _{L}\{2 \cdot f(81, L)-81 \cdot 2-L \cdot 1\} .
$$

Az elsőrendú optimumfeltétel:

$$
\begin{gathered}
2 \cdot 4 \cdot \frac{1}{2} \cdot 81^{\frac{1}{4}} \cdot L^{-\frac{1}{2}}-1=0 \\
12 \cdot L^{-\frac{1}{2}}=1 \\
144=L
\end{gathered}
$$

Elbocsátanak 180 egység munkaerôt. 
b. Az előző pontbeli számítás alapján a maximális rövid távú profit:

$$
2 \cdot f(81,144)-81 \cdot 2-144 \cdot 1=288-168-144=-24 .
$$

Zavaró lehet, hogy ez negatív, de mivel a 81 egység tôkét már kifizették, a nulla profit nem elérhetô alternatíva. Az adott körülmények között a -24 az elérhetô maximális profit.

c. A 4. feladat c. pontjában megadott tényezőkeresleti függvény szerint a hosszú távú tőkekereslet:

$$
K=\left(\frac{2 \cdot p^{2}}{r \cdot w}\right)^{2}
$$

így a jelenlegi paraméterek mellett

$$
K=\left(\frac{2 \cdot 2^{2}}{2 \cdot 1}\right)^{2}=16
$$

Az ugyanitt található levezetés alapján:

$$
\begin{aligned}
& L=K \cdot 2 \cdot \frac{r}{w}, \\
& L=16 \cdot 2 \cdot \frac{2}{1}, \\
& L=64 .
\end{aligned}
$$

Így a hosszú távú maximális profit:

$$
2 \cdot f(16,64)-16 \cdot 2-64 \cdot 1=128-32-64=32 .
$$

Vissza a feladathoz 
KÖLTSÉGMINIMALIZÁLÁS 
1. feladat: A termelési függvényt átrendezéssel kicsit átalakítjuk:

$$
\frac{y}{2}=\min \{\sqrt{K}, \sqrt{L}\} .
$$

a. Optimumban nyilván egyenlő mennyiségú tőkét, illetve munkát használunk fel, amiből

$$
\left(\frac{y}{2}\right)
$$

egység termék termeléséhez szükség van

$$
\left(\frac{y}{2}\right)^{2}=K=L
$$

mennyiségû tôkére, illetve ugyanannyi munkára. Ennek költsége nyilván:

$$
\left(\frac{y}{2}\right)^{2}\left(w_{K}+w_{L}\right)=(4+1)\left(\frac{y}{2}\right)^{2}=5\left(\frac{y}{2}\right)^{2} .
$$

Ebből a költségfüggvény:

$$
c(y)=5\left(\frac{y}{2}\right)^{2}=\frac{5}{4} y^{2} .
$$

b. Ekkor a tervezett

$$
y=20
$$

termelés költsége:

$$
c(20)=\frac{5}{4} 20^{2}=500 .
$$

Ezt a termelést nyilván

$$
\left(\frac{20}{2}\right)^{2}=100=L
$$

munkással állította elő az első cég. A második eszerint mindenképpen

$$
L=300
$$

munkást alkalmaz, (rövid távú) termelési függvénye:

$$
y=\min \{2 \sqrt{K}, 2 \sqrt{300}\} .
$$

Ha 30 egységet akar termelni, akkor ugyan túl sok munkást alkalmaz, hiszen

$$
2 \sqrt{300}>30
$$

de a munkások bérét ki kell fizetnie. A szükséges tőkemennyiség a

$$
30=2 \sqrt{K}
$$


összefüggésből számolható:

$$
K=225 \text {. }
$$

A vállalat összköltsége pedig:

$$
225 \cdot 4+300 \cdot 1=1200
$$

tehát

$$
1200-500=700
$$

garassal költ többet.

Vissza a feladathoz

2. feladat: A rövid távú termelési függvény:

$$
y=16^{1 / 4} T^{1 / 4}=2 T^{1 / 4},
$$

a. Az ehhez tartozó rövid távú költségfüggvény (lásd az előző példa a. pontjának gondolatmenetét!):

$$
c(y)=\frac{1}{16} \cdot y^{4}+64 .
$$

b. Rövid távon az optimum szükséges feltétele:

$$
p M P_{T}(T, 16)=w_{T},
$$

aminek konkrét alakja:

$$
16 \cdot\left(2 \cdot \frac{1}{4} \frac{1}{T^{\frac{3}{4}}}\right)=1
$$

Ebből:

$$
T=16 .
$$

Az optimális termelés ezek után:

$$
y=4,
$$

és az optimális profit:

$$
\pi=16 * 4-1 * 16-64=-16 .
$$


c. A hosszú távú termelés optimumfeltételei:

$$
\begin{aligned}
\operatorname{pMP}_{T}(T, L) & =w_{T}, \\
\operatorname{pMP}_{L}(T, L) & =w_{L},
\end{aligned}
$$

azaz:

$$
\begin{aligned}
& 16 *\left(\frac{1}{4} \frac{1}{T^{\frac{3}{4}}} L^{\frac{1}{4}}\right)=1, \\
& 16 *\left(T^{\frac{1}{4}} \frac{1}{4} \frac{1}{L^{\frac{3}{4}}}\right)=4 .
\end{aligned}
$$

Ezeket megoldva:

$$
T=8, \quad L=2, \quad y=2
$$

és az optimális profit:

$$
\pi=16 * 2-1 * 8^{\frac{1}{4}}-4 * 2^{\frac{1}{4}}=25.561 .
$$

Vissza a feladathoz

\section{3. feladat:}

a. Jelölje $d, k, c s$ és $r$ rendre a felhasznált disznóhús, krumpli, csirke és rizs kilóban mért mennyiségét. A termelési függvény:

$$
f(d, c s, k, r)=\min (5 \cdot d ; 4 \cdot k)+\min (4 \cdot c s ; 5 \cdot r) .
$$

b. Minél olcsóbban szeretnénk 10 adag ebédet előállítani, így a költségminimalizálási feladat:

$$
\min _{d, c s, k, r}\{1500 \cdot d+800 \cdot c s+160 \cdot k+250 \cdot r\}
$$

f.t.h. $f(d, c s, k, r)=10$.

Jelöljük $y_{p}$-vel az elkészített paprikás krumpli, $y_{c}$-vel a currys csirke mennyiségét. A termelési függvényben a disznóhús és a krumpli egymás tökéletes kiegészítői. Ha nem a kiegészítés arányában használjuk fel őket, akkor valamelyikből felesleges mennyiséget 
vettünk, költséget takaríthatnánk meg azzal, ha kevesebbet vettünk volna belôle. Így optimumban:

$$
y_{p}=5 \cdot d^{*}=4 \cdot k^{*}
$$

vagyis egy paprikás krumplihoz $1 / 5$ kiló (20 dkg) disznóhús és $1 / 4$ kiló (25dkg) krumpli kell. Jelöljük $w_{d}$-vel és $w_{k}$-val rendre a disznóhús és krumpli kilónkénti árát. Ekkor egy paprikás krumpli elkészítésének a költsége:

$$
\frac{w_{d}}{5}+\frac{w_{k}}{4} .
$$

A currys csirkét $y_{c}$-vel jelölve, hasonlóképpen teljesül az

$$
y_{c}=4 \cdot c s^{*}=5 \cdot r^{*}
$$

egyenlőség is, és az egy egység currys csirkére jutó költség:

$$
\frac{w_{c s}}{4}+\frac{w_{r}}{5}
$$

Összesen $y=y_{p}+y_{c}$ ebédet készít a vállalat. A kétfajta étel egymás tökéletes helyettesítője, mindegy, melyiket csinálják, mindkét étel egy ebéd. Ha a vállalat minél kisebb költséggel szeretne ebédeket készíteni, akkor az olcsóbb ételt fogja összedobni. Így tíz adag ebéd elkészítésének a költsége:

$$
\begin{aligned}
C\left(w_{d}, w_{c s}, w_{k}, w_{r}, y\right) & =y \cdot \min \left(\frac{w_{d}}{5}+\frac{w_{k}}{4} ; \frac{w_{c s}}{4}+\frac{w_{r}}{5}\right), \\
C(1500,800,160,250,10) & =10 \cdot \min (300+40 ; 200+50), \\
C(1500,800,160,250,10) & =2500 .
\end{aligned}
$$

c. 8 egység ebéd előállítható az alapanyagokból. A 9. egység előállításához szükség van még egy adag krumplira vagy még egy adag csirkehúsra. Ezekből a krumpli az olcsóbb, így azt fogják megvenni. A 10. egység előállításához szükség van egy adag disznóhúsra és krumplira, vagy egy adag csirkehúsra. Ebből az utóbbi az olcsóbb, így azt fogják megvásárolni. A költség összesen (azokat az inputokat is ki kell fizetni, ami mellett már elkötelezték magukat): $5 \cdot 340+5 \cdot 250=2950$.

Vissza a feladathoz

\section{4. feladat:}

a. A termelési függvény:

$$
f\left(x_{1}, x_{2}\right)=\min \left(\alpha \cdot x_{1} ; x_{2}\right) .
$$


b. A költségminimalizálási feladat:

$$
\begin{gathered}
\min _{x_{1}, x_{2}}\left\{2 \cdot x_{1}+1 \cdot x_{2}\right\}, \\
\text { f.t.h. } \min \left(\alpha \cdot x_{1} ; x_{2}\right)=y .
\end{gathered}
$$

Nem fognak felesleges mennyiségben inputokat vásárolni, így költségminimumban:

$$
y=\alpha \cdot x_{1}=x_{2} .
$$

Vagyis y darab akkumulátor előállításának a költsége:

$$
\begin{aligned}
C\left(w_{1}, w_{2}, y\right) & =w_{1} \cdot x_{1}+w_{2} \cdot x_{2}, \\
C(2,1, y) & =2 \cdot x_{1}+1 \cdot x_{2}, \\
C(2,1, y) & =2 \cdot \frac{y}{\alpha}+1 \cdot y .
\end{aligned}
$$

A feladat szövege szerint $C(2,1, y)=\frac{10}{\alpha} \cdot y$, így:

$$
\begin{aligned}
2 \cdot \frac{y}{\alpha}+y & =\frac{10}{\alpha} \cdot y, \\
2 \cdot y+\alpha \cdot y & =10 \cdot y, \\
\alpha & =8 .
\end{aligned}
$$

c. Lineáris a termelési függvény (és a költségfüggvény is), így a mérethozadék állandó.

Vissza a feladathoz

\section{5. feladat:}

a. Jelöljük $x_{1}$-gyel a feketeszenet, $x_{2}$-vel a lignitet. A szöveg szerint a termelési függvény állandó mérethozadékú, az inputok tökéletes helyettesítők, és a technikai helyettesítés határaránya 2, így a termelési függvény:

$$
f\left(x_{1} ; x_{2}\right)=2 \cdot x_{1}+x_{2} .
$$


A költségminimalizálási feladat:

$$
\begin{aligned}
& \min _{x_{1}, x_{2}}\left\{50 \cdot x_{1}+20 \cdot x_{2}\right\}, \\
& \text { f.t.h. } 2 \cdot x_{1}+x_{2}=y .
\end{aligned}
$$

Mivel

$$
\left|\operatorname{MRTS}\left(x_{1} ; x_{2}\right)\right|=2<\frac{50}{20}=\frac{w_{1}}{w_{2}},
$$

ezért minden belsô ponti inputkombinációban költséget takaríthatunk meg azzal, ha 1 egység feketeszenet 2 egység lignittel helyettesítünk. Ekkor a kibocsátás nem változik (azonos egyenlőtermék görbén maradunk), de a költség csökken (alacsonyabban fekvő egyenlőköltség egyenesre kerülünk). Így költségminimumban csak lignitet fognak felhasználni, vagyis az előállítandó y energiamennyiségtől függetlenül:

$$
x_{1}^{*}=0 .
$$

A termelési függvényből pedig:

$$
\begin{aligned}
2 \cdot x_{1}^{*}+x_{2}^{*} & =y, \\
x_{2}^{*} & =y .
\end{aligned}
$$

Így a költségfüggvény:

$$
\begin{aligned}
& C(20,50, y)=20 \cdot x_{1}^{*}+50 \cdot x_{2}^{*}, \\
& C(20,50, y)=20 \cdot y .
\end{aligned}
$$

Mivel gyakran előforduló félreértés, külön kiemelném, hogy az elsô egyenlet nem a költségfüggvény, csak a kiszámítása során használt egyenlet. A költségfüggvényben csak $y$ és a tényezóárak szerepelhetnek, $x_{1}$ és $x_{2}$ nem.

b. Rövid távon $\bar{x}_{1}=3$, így a rövid távú költségminimalizálási feladat:

$$
\min _{x_{2}}\left\{50 \cdot 3+20 \cdot x_{2}\right\}
$$

f.t.h. $2 \cdot 3+x_{2}=y$. 
Mivel fajlagosan még mindig olcsóbb a lignit a feketeszénnél (1 dollárnyi lignit több energiát nyújt, mint egy dollárnyi feketeszén), a három tonna feketeszénen kívül továbbra is csak ezt fogják használni, mégpedig:

$$
\begin{gathered}
2 \cdot \bar{x}_{1}+x_{2}^{*}=y, \\
x_{2}^{*}=y-6
\end{gathered}
$$

tonnát. Legalábbis ha ez a szám pozitív, mert ha nem, akkor nem használnak lignitet, a szükséges energiamennyiség előállításához elegendő a három tonna feketeszén. Így a rövid távú költségfüggvény:

$$
\begin{aligned}
& C_{S}(20,50, y, 3)=50 \cdot \bar{x}_{1}+20 \cdot x_{2}^{*}, \\
& C_{S}(20,50, y, 3)= \begin{cases}150+20 \cdot(y-6), & \text { ha } y>6 ; \\
150, & \text { ha } y \leq 6 .\end{cases}
\end{aligned}
$$

c. Az előző okfejtéshez hasonlóan:

$$
\begin{aligned}
& C_{S}\left(20,50, y, \bar{x}_{1}\right)=50 \cdot \bar{x}_{1}+20 \cdot x_{2}^{*}, \\
& C_{S}\left(20,50, y, \bar{x}_{1}\right)=50 \cdot \bar{x}_{1}+20 \cdot\left(y-2 \cdot \bar{x}_{1}\right), \\
& C_{S}\left(20,50, y, \bar{x}_{1}\right)=10 \cdot \bar{x}_{1}+20 \cdot y .
\end{aligned}
$$

Ugyanakkor a szöveg szerint

$$
C_{S}\left(20,50, y, \bar{x}_{1}\right)=20 \cdot y+70,
$$

de ez a kettő csak úgy lehet egyszerre igaz, ha

$$
\bar{x}_{1}=7 \text {. }
$$

Vissza a feladathoz

\section{6. feladat:}

a. Növekvő. Kétszeres inputfelhasználás nyolcszoros kibocsátást eredményez. Profitmaximum így állandó árak mellett nem létezik, adott kibocsátási szinthez azonban tartozik minimális költség. 
b. Az optimumfeladat (költségminimalizálás):

$$
\min _{x_{1}, x_{2}}\left\{w_{1} \cdot x_{1}+w_{2} \cdot x_{2}\right\},
$$

f.t.h. $y=x_{1} \cdot x_{2}^{2}$.

Az optimumfeltételből:

$$
\begin{gathered}
\left|\operatorname{MRTS}\left(x_{1}, x_{2}\right)\right|=\frac{w_{1}}{w_{2}}, \\
\frac{M P_{1}\left(x_{1}, x_{2}\right)}{M P_{2}\left(x_{1}, x_{2}\right)}=\frac{w_{1}}{w_{2}}, \\
\frac{x_{2}^{2}}{2 \cdot x_{1} \cdot x_{2}}=\frac{w_{1}}{5}, \\
\frac{x_{2}}{2 \cdot x_{1}}=\frac{w_{1}}{5}, \\
x_{2}=\frac{2 \cdot x_{1} \cdot w_{1}}{5}
\end{gathered}
$$

Ezt behelyettesítve a mennyiségre kapott feltételbe:

$$
\begin{gathered}
y=x_{1} \cdot x_{2}^{2}, \\
y=x_{1} \cdot\left(\frac{2 \cdot x_{1} \cdot w_{1}}{5}\right)^{2}, \\
y=\frac{4 \cdot x_{1}^{3} \cdot w_{1}^{2}}{25} .
\end{gathered}
$$

Ezt átrendezve $x_{1}$-re, megkapjuk az

$$
x_{1}\left(w_{1}, 5, y\right)=\sqrt[3]{\frac{5 \cdot y}{4 \cdot w_{1}^{2}}}
$$

tényezőkeresleti függvényt. 
c. Ez egy Cobb-Douglas-típusú függvény. A költségek a hatványok arányában oszlanak meg az inputok között, szóval az összes költség harmada megy az első inputra, és kétharmada a második inputra, azaz:

$$
w_{2} \cdot x_{2}=5 \cdot 40=200=\frac{2}{3} \cdot C\left(w_{1}, 5, y\right) .
$$

Ebből a teljes költség:

$$
C\left(w_{1}, 5, y\right)=300 \text {. }
$$

Ha valaki nem hinné el, hogy a Cobb-Douglas-tulajdonság költségfüggvényeknél is múködik:

A b. pont számításait felhasználva:

$$
\begin{gathered}
\left|\operatorname{MRTS}\left(x_{1}, x_{2}\right)\right|=\frac{x_{2}}{2 \cdot x_{1}}=\frac{w_{1}}{w_{2}}, \\
w_{2} \cdot x_{2}=2 \cdot w_{1} \cdot x_{1}, \\
w_{2} \cdot x_{2}=\frac{2}{3}\left(\frac{1}{2} \cdot w_{2} \cdot x_{2}+w_{2} \cdot x_{2}\right), \\
w_{2} \cdot x_{2}=\frac{2}{3}\left(\frac{1}{2} \cdot 2 \cdot w_{1} \cdot x_{1}+w_{2} \cdot x_{2}\right), \\
w_{2} \cdot x_{2}=\frac{2}{3}\left(w_{1} \cdot x_{1}+w_{2} \cdot x_{2}\right) .
\end{gathered}
$$

Azaz az összes költség kétharmadát költjük a második inputra, és ebből következően egyharmadát az első inputra.

d. A b. pont alapján:

$$
\begin{gathered}
x_{1}\left(w_{1}, 5, y\right)=\sqrt[3]{\frac{5 \cdot y}{4 \cdot w_{1}^{2}}}, \\
w_{1} \cdot x_{1}\left(w_{1}, 5, y\right)=\sqrt[3]{\frac{w_{1} \cdot 5 \cdot y}{4}} .
\end{gathered}
$$

A c. pont alapján pedig a Cobb-Douglas-tulajdonság miatt:

$$
\begin{aligned}
& C\left(w_{1}, 5, y\right)=3 \cdot w_{1} \cdot x_{1}\left(w_{1}, 5, y\right), \\
& C\left(w_{1}, 5, y\right)=3 \cdot \sqrt[3]{\frac{w_{1} \cdot 5 \cdot y}{4}} .
\end{aligned}
$$


e. Mivel $x_{2}=40$ és $y=40000$, a termelési függvényből

$$
\begin{aligned}
x_{1} \cdot x_{2}^{2} & =y, \\
x_{1} \cdot 40^{2} & =40000, \\
x_{1} & =25 .
\end{aligned}
$$

Ez egy belső ponti költségminimum, így:

$$
\begin{aligned}
\left|\operatorname{MRTS}\left(x_{1}, x_{2}\right)\right| & =\frac{w_{1}}{w_{2}}, \\
\frac{x_{2}}{2 \cdot x_{1}} & =\frac{w_{1}}{w_{2}} .
\end{aligned}
$$

Ebbe behelyettesítve az eddigi adatokat:

$$
\begin{aligned}
\frac{40}{2 \cdot 25} & =\frac{w_{1}}{5}, \\
4 & =w_{1} .
\end{aligned}
$$

f. A rövid távú költségminimumban:

$$
\begin{aligned}
& y=x_{1}^{*} \cdot \bar{x}_{2}^{2}, \\
& y=x_{1}^{*} \cdot 1600, \\
& x_{1}^{*}=\frac{y}{1600} .
\end{aligned}
$$

A rövid távú költségfüggvény:

$$
\begin{aligned}
& C_{S}\left(w_{1}, w_{2}, y, \bar{x}_{2}\right)=w_{1} \cdot x_{1}^{*}+w_{2} \cdot \bar{x}_{2}, \\
& C_{S}\left(w_{1}, w_{2}, y, \bar{x}_{2}\right)=4 \cdot \frac{y}{1600}+5 \cdot 40, \\
& C_{S}\left(w_{1}, w_{2}, y, \bar{x}_{2}\right)=\frac{y}{400}+200 .
\end{aligned}
$$

Vissza a feladathoz 
KÖLTSÉGGÖRBÉK 
1. feladat: Állítsuk először külön-külön elő a két eljáráshoz tartozó költségfüggvényt!

Keverés: Akámennyi krumplistésztát keverünk, a termelési függvény alapján ugyanannyi keverőlapátot használunk, mint lapátkeverőt. Jelöljük ezek közös mennyiségét az $x$ szimbólummal. Ebből az $x$ mennyiségből, aminek költsége

$$
(1+4) x=5 x
$$

garas,

$$
\sqrt{x}=y
$$

adag krumplistésztát tudunk előállítani. Ebből az is következik, hogy y adag krumplistésztához

$$
x=y^{2}
$$

darab keverőlapátot, illetve lapátkeverôt kell használnunk. Mindebből y adag kumplistészta teljes költsége:

$$
c_{k e v}(y)=5 y^{2} .
$$

Kavarás: A kavarógép költsége állandó költség, független az előállított krumplistészta mennyiségétől. A változó költséget pedig a határköltségből integrálással tudjuk kiszámítani:

$$
V C(y)=\int_{0}^{y} M C(z) d z=\int_{0}^{y}(2 z-2) d z=y^{2}-2 y .
$$

Ebből a kavarás teljesköltségfüggvénye:

$$
c_{k a v}(y)=y^{2}-2 y+6 .
$$

a. A krumplistészta-termelés teljesköltségfüggvénye ezek után:

$$
\begin{aligned}
c(y) & =\min \left\{c_{\text {kev }}(y), c_{\text {kav }}(y)\right\}= \\
& =\left\{\begin{array}{l}
5 y^{2}, \text { ha } y \leqq 1 ; \\
y^{2}-2 y+6, \text { ha } y>1 .
\end{array}\right.
\end{aligned}
$$

b. Legyen $y=0.5$, ekkor:

$$
c(0.5)=1.25 \text {, }
$$

legyen most $y=2$, ekkor:

$$
c(2)=6 \text {. }
$$

c. A határköltségfüggvény:

$$
M C(y)=\left\{\begin{array}{l}
10 y, \text { ha } y \leqq 1 \\
2 y^{2}-2, \text { ha } y>1 .
\end{array}\right.
$$

(Vegyük észre, hogy a határköltségfüggvénynek szakadása van az y = 1 pontban!)

Vissza a feladathoz 


\section{2. feladat:}

a. A költségfüggvény változó költségből és fix költségből áll. Az y kibocsátáshoz tartózó változó költség:

$$
\begin{aligned}
V C_{A}(y) & =\int_{0}^{y} M C_{A}(z) d z=\int 2 \cdot y d y=y^{2}, \\
C_{A}(y) & =F_{A}+V C_{A}(y)=0+y^{2}=y^{2} .
\end{aligned}
$$

b. Akkor fog befektetni, ha ezzel az összköltsége kisebb lesz. Először kiszámoljuk a befektetés utáni költségfüggvényt, majd összehasonlítjuk a kettôt:

$$
\begin{gathered}
C_{B}(y)=F^{\prime}+\int_{0}^{y} M C_{B}(z) d z=50+\int_{0}^{y} z d z=50+\frac{y^{2}}{2}, \\
C_{A}(y) \geq C_{B}(y), \\
y^{2} \geq 50+\frac{y^{2}}{2}, \\
y^{2} \geq 100, \\
y \geq 10,
\end{gathered}
$$

azaz legalább 10 kép készítése esetén éri meg befektetni.

c. A legkisebb költség persze a két technológia költsége közül a kisebb, vagyis:

$$
C(y)=\min \left(C_{A}(y), C_{B}(y)\right) .
$$

A b. pontbeli számítások alapján:

$$
C(y)=\left\{\begin{array}{cc}
y^{2}, & \text { ha } y \leq 10 ; \\
\frac{y^{2}}{2}+50, & \text { ha } y>10 .
\end{array}\right.
$$

(Mindegy, hogy az $y=10$ részt hová rakja, ott ugyanazt az értéket adja a két képlet.)

Vissza a feladathoz 


\section{3. feladat:}

a. $\mathrm{Az}$

$$
A C(y)=y+8+\frac{25}{y}
$$

függvény minimumát keressük. Egyrészt ugye tudjuk, hogy ha $y^{*}$ az $A C(y)$ függvény minimumhelye, akkor:

$$
A C\left(y^{*}\right)=M C\left(y^{*}\right) .
$$

Vagyis:

$$
\begin{aligned}
A C\left(y^{*}\right) & =M C\left(y^{*}\right), \\
y^{*}+8+\frac{25}{y^{*}} & =2 \cdot y^{*}+8, \\
\frac{25}{y^{*}} & =y^{*}, \\
5 & =y^{*} .
\end{aligned}
$$

Ugyanezt megkaphattuk volna sima szélsőérték-kereséssel:

$$
\min _{y} A C(y) .
$$

Az $A C(y)$ függvényt deriválva megkapjuk a lokális minimum elsőrendú feltételét:

$$
\begin{aligned}
1-\frac{25}{\left(y^{*}\right)^{2}} & =0, \\
y^{*} & =5 .
\end{aligned}
$$

Vagyis a minimumhely:

$$
\arg \min _{y} A C(y)=5
$$

b. A minimum értéke:

$$
\min _{y} A C(y)=A C(5)=5+8+\frac{25}{5}=18 .
$$

c. Nem. Az előbb láttuk, hogy egy termékre legalább 18 egységnyi költség jut. Ha termékenként 15 egységnyi pénzt lehet kapni, akkor minden egyes termék veszteséges lesz, mivel

$$
p=15<18 \leq A C(y) .
$$


d. $\mathrm{Az}$

$$
A V C(y)=y+8
$$

függvény minimumát keressük. A függvény deriváltja minden y mellett pozitív, és $y$ nem lehet negatív, így az átlagos változóköltség-függvény minimumhelye nyilván $y^{*}=$ 0 .

e. A minimum értéke:

$$
\min _{y} A V C(y)=A V C(0)=0+8=8 .
$$

Vissza a feladathoz

\section{4. feladat:}

a. $\mathrm{Az}$

$$
A V C(y)=y^{2}-4 \cdot y+12
$$

függvény minimumát keressük. Ha abból indulunk ki, hogy $A V C(y)=M C(y)$, akkor két megoldást is kapunk:

$$
\begin{aligned}
\operatorname{MC}(y) & =\operatorname{AVC}(y), \\
3 \cdot y^{2}-8 \cdot y+12 & =y^{2}-4 \cdot y+12, \\
2 \cdot y^{2}-4 \cdot y & =0 \\
2 \cdot y \cdot(y-2) & =0, \\
y_{1}=0, & \quad y_{2}=2 .
\end{aligned}
$$

Ezek közül azonban az elsô nem a minimumponthoz tartozik: $y=0$-nál az átlagos változóköltség-függvény még csökken. Ez azért van, mert $A V C(y)=M C(y)$ a (belső ponti) minimumhely szükséges, de nem elégséges feltétele. Vagyis a minimumhelyen 
teljesül, de csak mert valamilyen $y$-ra teljesül, még nem biztos, hogy az a minimumhely. Ha a rendes,

$$
\arg \min _{y} A V C(y)
$$

utat követjük, akkor:

$$
\begin{aligned}
\frac{\mathrm{d} A V C(y)}{\mathrm{d} y} & =0, \\
2 \cdot y^{*}-4 & =0, \\
y^{*} & =2 .
\end{aligned}
$$

A minimum értéke:

$$
\min _{y} A V C(y)=4-8+12=8
$$

b. Ha nem termel a vállalat, akkor a fix költséget mindenképpen ki kell fizetni, de mást nem. Bevétele sincs, így a profitja

$$
\Pi=-25 .
$$

Ha termel a vállalat, akkor termékenként a fix költségen felül még az átlagos változó költséget is meg kell fizetnie. Ahogy az előbb láttuk, ez legalább 8. Ha a vállalat nem kap legalább 8 egység pénzt termékenként, akkor

$$
p<8 \leq A V C(y),
$$

így minden egyes újabb jószág kibocsátása újabb veszteséget okoz neki. De ha $p>8$, akkor ugyanezen okból megéri termelni: Például $y=2$-es kibocsátás mellett nagyobb a bevétel, mint a változó költség, így növeli a profitot a termelés. Fontos megjegyezni, hogy nem biztos, hogy termelés mellett pozitív lesz a profit, de nagyobb, mintha nem termelnénk, vagyis ez a kisebbik rossz. Ha $p=8$, akkor mindegy, hogy $y=2$, vagy $y=0$, a profit mindkét esetben $\Pi=-25$. Így ez a keresett szám, ez a legkisebb ár, amelyre nem csak $y=0$ mellett maximális a profit.

Vissza a feladathoz 


\section{5. feladat:}

a. A változóköltség-függvény:

$$
V C(y)=\int_{0}^{y} M C(z) d z=y^{2}+6 \cdot y
$$

A költségfüggvényhez még a fix költségek járulnak hozzá, így:

$$
C(y)=\left\{\begin{array}{cc}
25, & \text { ha } y=0 \\
y^{2}+6 \cdot y+169, & \text { ha } y>0
\end{array}\right.
$$

b. Mivel $y=0$ mellett az átlagköltségfüggvények nem értelmezhetőek, a kvázifix költség nem okoz zavart a számításukkor: Mindig y $>0$ részen vagyunk. Az átlagköltségfüggvény:

$$
A C(y)=y+6+\frac{169}{y} .
$$

Az $A C(y)$ függvényt deriválva megkapjuk a lokális minimum elsőrendú feltételét:

$$
\begin{aligned}
1-\frac{169}{\left(y^{*}\right)^{2}} & =0, \\
1 & =\frac{169}{\left(y^{*}\right)^{2}}, \\
13 & =y^{*} .
\end{aligned}
$$

Vagyis a minimumhely:

$$
\arg \min _{y} A C(y)=13
$$

A minimum értéke:

$$
\min _{y} A C(y)=A C(13)=13+6+\frac{169}{13}=32 .
$$

c. A korábban leírtak szerint $p \geq 32$ mellett nem lesz veszteséges a vállalat, ezek közül a legkisebb $p=32$.

d. Az átlagos változóköltség-függvény:

$$
A V C(y)=y+6 \text {. }
$$

Mivel

$$
\frac{\mathrm{d} A V C(y)}{\mathrm{d} y}=1>0,
$$

ezért ennek a minimuma $y^{*}=0$-ban van. A minimum értéke:

$$
\min _{y} A V C(y)=0+6=6 \text {. }
$$


e. Itt bezavar a kvázifix költség. Ha egyáltalán nem termel a vállalat, csak a fix költséget kell kifizetni, így a profitja - 25 lesz. Ezt kell összehasonlítani azzal a helyzettel, ha termel. Lényegében az árnak nemcsak az átlagos változó költséget, hanem az átlagos kvázifix költséget is fedeznie kell. Így csak akkor éri meg termelni, ha

$$
\begin{aligned}
& p \geq \min _{y}\left(\operatorname{AVC}(y)+\frac{144}{y}\right), \\
& p \geq \min _{y}\left(y+6+\frac{144}{y}\right) .
\end{aligned}
$$

A jobb oldalon szereplő kifizetés minimumhelye:

$$
\begin{aligned}
\frac{\mathrm{d}\left(y+6+\frac{144}{y}\right)}{\mathrm{d} y} & =0, \\
1-\frac{144}{y^{2}} & \geq 0, \\
12 & =y^{*},
\end{aligned}
$$

a minimum értéke:

$$
\min _{y}\left(y+6+\frac{144}{y}\right)=12+6+12=30 .
$$

Akkor nem növeli tehát a veszteséget a termelés, ha $p \geq 30$. Ezek közül a legkisebb ár a $p=30$.

Készen vagyunk, de lássuk be, ezt nem hisszük el, úgyhogy gyors ellenőrzés: Ha nem termelünk, a profit -25 . Ha $p=30+\varepsilon$, és termelünk 12 egységet, akkor

$$
\begin{aligned}
& \Pi=p \cdot y-y^{2}-6 \cdot y-169, \\
& \Pi=(30+\varepsilon) \cdot 12-144-6 \cdot 12-169, \\
& \Pi=360+\varepsilon \cdot 12-385, \\
& \Pi=\varepsilon \cdot 12-25 .
\end{aligned}
$$

Ez tényleg éppen minden $\varepsilon \geq 0$ mellett lesz nem kisebb, mint -25 . (Ha $\varepsilon>0$, akkor konkrétan nő is a profit.) Egyébként nem minden $\varepsilon$ mellett $y=12$ a profitmaximalizáló kibocsátás, de most ez nem is volt kérdés.

Vissza a feladathoz 


\section{6. feladat:}

a. A Költségminimalizálás fejezetben tanultak alapján a költségminimumfeladat:

$$
\begin{gathered}
\min _{s, i}\{2000 \cdot s+4500 \cdot i\}, \\
\text { f.t.h. } \sqrt[3]{s \cdot i}=y
\end{gathered}
$$

Optimumban:

$$
\begin{aligned}
|\operatorname{MRTS}(s, i)| & =\frac{w_{s}}{w_{i}}, \\
\frac{i}{s} & =\frac{2000}{4500}, \\
\frac{9}{4} \cdot i & =s .
\end{aligned}
$$

Ha y ügyfelet akarnak kiszolgálni, akkor:

$$
\begin{aligned}
\sqrt[3]{s \cdot i} & =y, \\
\sqrt[3]{\frac{9}{4} \cdot i \cdot i} & =y, \\
i & =\frac{2}{3} \cdot y^{\frac{3}{2}}
\end{aligned}
$$

darab irodára és

$$
\begin{aligned}
& s=\frac{9}{4} \cdot i, \\
& s=\frac{3}{2} \cdot y^{\frac{3}{2}}
\end{aligned}
$$

szakértőre van szükség. Ennek a költsége:

$$
\begin{aligned}
& C(y)=2000 \cdot s+4500 \cdot i, \\
& C(y)=6000 \cdot y^{\frac{3}{2}} .
\end{aligned}
$$


b. A Profitmaximalizálás fejezetben tanultak szerint a profitmaximum-feladat:

$$
\max _{s, i}\{54000 \cdot \sqrt[3]{s \cdot i}-2000 \cdot s-4500 \cdot i\}
$$

Az elsőrendû optimumfeltételek:

$$
\begin{aligned}
& 54000 \cdot \frac{1}{3} \cdot \sqrt[3]{\frac{i}{s^{2}}}=2000 \\
& 54000 \cdot \frac{1}{3} \cdot \sqrt[3]{\frac{s}{i^{2}}}=4500
\end{aligned}
$$

Ezek hányadosából egyrészt megkapjuk a fenti

$$
\frac{9}{4} \cdot i=s
$$

költségminimalizáló összefüggést, majd ezt visszahelyettesítve mondjuk az $s$ szerinti optimumfeltételbe:

$$
\begin{gathered}
54000 \cdot \frac{1}{3} \cdot \sqrt[3]{\frac{i}{\left(\frac{9}{4} \cdot i\right)^{2}}}=2000 \\
\frac{16}{81} \cdot \frac{1}{i}=\left(\frac{6000}{54000}\right)^{3} \\
144=i \\
s=\frac{9}{4} \cdot 144=324 \\
y=\sqrt[3]{144 \cdot 324}=36
\end{gathered}
$$

Az ügyfelek kiszolgálásának költsége pedig

$$
C(36)=6000 \cdot 36^{\frac{3}{2}}=1296000
$$

euró

c. A profitmaximum-feladatban most figyelembe kell venni a Zrt. tulajdonában lévő irodákat is. Így a termelés során felhasznált első 200 iroda ingyen van, így $i$ iroda használatának költsége csak 4500 • $(i-200)$ euró, vagy ha 200-nál kevesebb irodát 
használnak, akkor a megmaradt irodák kiadásából további 4500 $(200-i)$ euró haszon származik. Mindkét helyzetet leírja a

$$
\max _{s, i}\{54000 \cdot \sqrt[3]{s \cdot i}-2000 \cdot s-4500 \cdot(i-200)\}
$$

optimumfeladat. Ugyanakkor ezt átírhatjuk a

$$
\max _{s, i}\{54000 \cdot \sqrt[3]{s \cdot i}-2000 \cdot s-4500 \cdot i+900000\}
$$

alakba is. Az elsőrendû optimumfeltételekben itt nem jelenik meg a 900000, nem változtatja meg az optimumhelyet. Így ugyanaz lesz az optimális tényezőfelhasználás, mint az előző pontban, $i=144, s=324$, és továbbra is 36 ügyfelet szolgál ki a Zrt. A haszon nagyobb 900000 euróval, ami a 200 iroda értéke.

Most következik a feladat legfontosabb része. Az ügyfelek kiszolgálásának a költsége változatlanul 1296000. Logikusnak tûnhet azt mondani, hogy a költség ennek csak a fele, 648000, hiszen az irodákért nem kell fizetni. De a termelési folyamat (a feladatban ez a tanácsadás) költsége nem ennyi, mert azzal, hogy a Zrt. maga használja az irodáit, nem tudja kiadni őket, így nyereségtől esik el. Ez az alternatíva költség egy fajtája, és közgazdaságilag a termelési költségbe ezt is beleértjük. Fontos, hogy számviteli szempontból ez nem költség, a könyvelésben nem jelenne meg. Mi a közgazdasági szemléletet fogjuk követni, mert így nem kell azzal foglalkozni, hogy kinek a tulajdonában vannak a felhasznált erőforrások, és később könnyebb lesz vizsgálni, hogy hatékonyan zajlik-e a termelés. Illetve még egy okból logikus a közgazdasági költség: nem egyértelmú, hány irodát ad ki a Zrt. 144 irodát használ a tanácsadás során, de lehet, hogy a 200 saját irodájából 100-at kiad, és bérel még 44-et. Ez a profitot nem változtatná meg, mivel a bérleti díj és a bérbeadásból származó haszon is irodánként 4500 euró, így lehetséges viselkedése a vállalatnak. A közgazdasági költség ettől független, mivel továbbra is összesen 144 irodát használ a vállalat, és mindegy, hogy ezek közül mennyi saját tulajdonú. A számviteli költség viszont függ attól, hogy hány irodát bérel a vállalat. Így abból, hogy a vállalat optimálisan viselkedik, a számviteli költséget még nem is tudnánk meghatározni.

Vissza a feladathoz 
VÁLLALATI KÍNÁLAT 
1. feladat: Miután a határköltségfüggvény a $(0,2)$ pontból induló félegyenes, ezért legyen a képlete:

$$
M C(y)=a y+2,
$$

ahol $a$ a félegyenes meredeksége.

Mivel a határköltségfüggvény a változóköltség-függvény deriváltja:

$$
M C(y)=V C^{\prime}(y),
$$

ezért a változóköltség-függvényt megkapjuk, mint a határköltségfüggvény primitív függvényét (antideriváltját):

$$
V C(y)=\int M C(y) d y .
$$

A konkrét alakban:

$$
V C(y)=\int M C(y) d y=\int(a y+2) d y=\frac{a}{2} y^{2}+2 y .
$$

Ebből az átlagos változóköltség-függvény:

$$
A V C(y)=\frac{V C(y)}{y}=\frac{a}{2} y+2 .
$$

Az üzembezárási pont ennek minimumpontja, vagyis ahol

$$
A V C(y)=M C(y)
$$

amiből:

$$
\begin{aligned}
a y+2 & =\frac{a}{2} y+2, \\
y & =0,
\end{aligned}
$$

azaz a $(0,2)$ pont az üzembezárási pont is egyben. Ebben a pontban az árbevétel és a változó költség nyilván zérus (mert nincs termelés), ezért a termelői többlet is az, hiszen

$$
T R=\Pi-V C-F C,
$$

amiből:

$$
\begin{gathered}
T T=\Pi+F C=T R-V C=0 \\
\Pi=-F C .
\end{gathered}
$$

A fedezeti pontban a profit definíció szerint zérus, és így a termelői többlet ott az $F C$. Ez a példa szövege szerint 16 egységgel több, mint az üzembezárási pontban, innen

$$
F C=16 .
$$


Itt a fedezeti pontban:

$$
\begin{aligned}
A C(y) & =M C(y), \\
\frac{a}{2} y+2+\frac{16}{y} & =a y+2,
\end{aligned}
$$

amiből:

$$
\frac{a}{2} y^{2}=16
$$

Másfelől ebben a pontban a változó költség:

$$
\frac{a}{2} y^{2}+2 y=24
$$

amiből az előző összefüggéssel:

$$
\begin{aligned}
2 y & =8 \\
y & =4, \\
a & =2 .
\end{aligned}
$$

A teljesköltségfüggvény tehát:

$$
T C(y)=y^{2}+2 y+16 .
$$

Vissza a feladathoz

2. feladat: A cég átlagköltségfüggvénye:

$$
A C(y)=2 y+a+\frac{18}{y} .
$$

Határköltségfüggvénye:

$$
M C(y)=4 y+a .
$$

a. Ha optimális mennyiséget termel, akkor:

$$
M C(y)=4 y+a=23=p,
$$

amiből:

$$
a=23-4 y
$$

A cég profitja:

$$
(p-A C(y)) y=\left(23-\left(2 y+23-4 y+\frac{18}{y}\right)\right) y=32,
$$

ebből:

$$
y=5, \Rightarrow a=3 \text {. }
$$


b. Ha bevétele éppen fedezi költségeit, akkor:

$$
p=M C(y)=A C(y),
$$

azaz:

amiből:

$$
p=4 y+3=2 y+3+\frac{18}{y},
$$

$$
y=3, \Rightarrow p=15 \text {. }
$$

c. A legmagasabb ár, ami mellett nem termel, az az üzembezárási ponthoz tartozó ár. Itt

$$
p=\min _{y \geqq 0} A V C(y)=\min _{y \geqq 0} 2 y+3,
$$

azaz:

$$
y=0, \Rightarrow p=3 \text {. }
$$

Vissza a feladathoz

3. feladat: A diós-mákos csemege y egysége előállításának termelési függvénye:

$$
y=\sqrt{\min \{d, m\}},
$$

a. Az ehhez tartozó költségfüggvény:

$$
c(y)=\left(w_{d}+w_{m}\right) y^{2}+F=(14+16) y^{2}+500,
$$

hiszen a többi eszköz költsége fix költség.

b. Mivel a vállalat árelfogadó, optimumfeltétele:

$$
p=M C(y),
$$

azaz:

$$
p=60 y \text {. }
$$

Ebből a $p=600$ behelyettesítéssel:

$$
y=10 .
$$

c. A vállalat olyan árak mellett nem termel, amelyek nem nagyobbak az átlagos változó költség minimális értékénél.

$$
A V C(y)=30 y,
$$

ennek minimális értéke a nemnegatív termelések mellett zérus, így a vállalat minden pozitív ár mellett termel.

Vissza a feladathoz 
4. feladat: A tökéletesen versenyző vállalat fedezeti pontja az átlagköltségfüggvény minimumpontja.

a. Itt az átlagköltség egyenlő a határköltséggel:

$$
M C(y)=2 y+2=y+2+\frac{100}{y}=A C(y),
$$

amiből:

$$
y=100 .
$$

b. A minimális ár az üzembezárási ponthoz tartozó ár, ahol az átlagos változó költség egyenlő a határköltséggel:

$$
M C(y)=2 y+2=y+2=A V C(y),
$$

amiből:

$$
y=0, \quad p=2 .
$$

c. A tökéletesen versenyző vállalat esetében $M C(y)=p$, amiből:

$$
y=\frac{p-2}{2} .
$$

A profitfüggvény ezek után:

$$
\begin{aligned}
\Pi(p) & =p\left(\frac{p-2}{2}\right)-\left(\frac{p-2}{2}\right)^{2}-2 \cdot \frac{p-2}{2}-100= \\
& =\frac{1}{4} p^{2}-p-99=\left(\frac{p}{2}-1\right)^{2}-100
\end{aligned}
$$

Vissza a feladathoz

\section{5. feladat:}

a. Az üzembezárási ponthoz tartozó mennyiség mellett az $A V C(y)$ minimális:

$$
\begin{gathered}
C(y)=y^{3}-4 \cdot y^{2}+12 \cdot y+25, \\
A V C(y)=y^{2}-4 \cdot y+12=(y-2)^{2}+8, \\
\arg \min _{y} A V C(y)=y^{*}=2 .
\end{gathered}
$$

Az üzembezárási ponthoz tartozó ár:

$$
A V C(2)=4-8+12=8 .
$$


b. Az üzembezárási ponthoz tartozó ár alatt a bevételek már a változó költséget sem fedezik, ezért nem éri meg termelni. Vagyis a vállalat optimális kibocsátása $y(p)=$ 0 , ha $p<8$. Ha az ár ennél nagyobb, akkor vállalat profitmaximumát a

$$
\max _{y}\{p \cdot y-C(y)\}
$$

optimumfeladat megoldásával kapjuk. Az optimum elsőrendû́ feltétele:

$$
p-M C(y)=0,
$$

vagyis:

$$
\begin{aligned}
& p=M C(y), \\
& p=3 \cdot y^{2}-8 \cdot y+12 .
\end{aligned}
$$

A másodfokú egyenlet megoldóképletéből:

$$
y=\frac{8 \pm \sqrt{8^{2}-4 \cdot 3 \cdot(12-p)}}{2 \cdot 3} .
$$

A kínálat a határköltség növekvő szakaszán van, így azt az

$$
y(p)=\frac{4+\sqrt{16-3 \cdot(12-p)}}{3}=\frac{4+\sqrt{3 \cdot p-20}}{3}
$$

gyök adja meg. Ahogy azonban korábban írtuk, ez csak akkor érvényesül, ha $p \geq 8$. Így a kínálati függvény:

$$
y(p)=\left\{\begin{array}{cc}
0, & \text { ha } p<8 ; \\
\{0,2\}, & \text { ha } p=8 ; \\
\frac{4+\sqrt{3 \cdot p-20}}{3}, & \text { ha } p>8 .
\end{array}\right.
$$

Vissza a feladathoz

\section{6. feladat:}

a. A határköltség:

$$
M C(y)=\frac{\mathrm{d} V C(y)}{\mathrm{d} y}=2 \cdot y+2 .
$$

Versenyzôi vállalat profitmaximuma:

$$
\begin{aligned}
& p=M C(y), \\
& 4=2 \cdot y+2, \\
& y=1 .
\end{aligned}
$$


A fedezeti pontban a vállalat haszna nulla, így:

$$
\begin{aligned}
\Pi(4) & =4 \cdot 1-1^{2}-2 \cdot 1-F=0, \\
F & =1 .
\end{aligned}
$$

b. Az üzembezárási ponthoz tartozó ár az átlagos változóköltség-függvény minimuma.

$$
\begin{aligned}
V C(y) & =y^{2}+2 \cdot y, \\
A V C(y) & =y+2, \\
\min _{y} A V C(y) & =2 .
\end{aligned}
$$

c. A kínálati függvény, ha $y>0$ :

$$
\begin{aligned}
2 \cdot y+2 & =M C(y)=p, \\
y(p) & =\frac{p-2}{2} .
\end{aligned}
$$

Vagyis $y(p)=\frac{p-2}{2}$, ha $p \geq 2$. Ez utóbbi feltétel amúgy elég nyilvánvaló volt, mert $p<2$ mellett a képlet negatív kibocsátást írna elő.

Vissza a feladathoz

\section{7. feladat:}

a. Mivel a határköltség konstans, a költségfüggvény:

$$
C(y)=c \cdot y+F
$$

alakú. Ha a piaci ár 12, és emellett 7 gyurmát termelnek, a profit:

$$
p \cdot y-c \cdot y-F=(p-c) \cdot y-F .
$$

Ha ez maximális, az y szerinti elsô derivált 0 :

$$
\begin{aligned}
p-c & =0, \\
c & =p=12 .
\end{aligned}
$$


A szöveg szerint ez 7 egységnyi termelés mellett -6 :

$$
\begin{gathered}
(p-c) \cdot y-F=(12-12) \cdot 7-F=-6, \\
F=6 .
\end{gathered}
$$

A költségfüggvény: $C(y)=12 \cdot y+6$.

b. Ahogy azt az optimumfeltételből láttuk, csak akkor lesz profitmaximum, ha $p=c=12$. Ha $p<c$, akkor bármekkora mennyiség termelése mellett kisebb áron lehet eladni egy adag gyurmát, mint amennyibe a megtermelése kerül. Így minél kevesebbet termel a vállalat, annál nagyobb a profit. Ha $p>c$, akkor bármekkora mennyiség termelése mellett nagyobb áron lehet eladni egy újabb gyurmát, mint amennyi a termelés költsége. Így minél többet termel a vállalat, annál nagyobb a profit. A vállalat kínálati függvénye:

$$
y(p)= \begin{cases}0, & \text { ha } p<12 ; \\ \text { bármekkora mennyiség, } & \text { ha } p=12 ; \\ \infty, & \text { ha } p>12 .\end{cases}
$$

Vissza a feladathoz

\section{8. feladat:}

a. A vállalat haszna $y$ kibocsátás és $p$ ár mellett:

$$
p \cdot y-C(y)=p \cdot y-y^{2}-36 .
$$

Ezt $y$ szerint maximalizálva:

$$
\begin{aligned}
\frac{\mathrm{d}\left(p \cdot y-y^{2}-36\right)}{\mathrm{d} y} & =0, \\
p-2 \cdot y & =0,
\end{aligned}
$$

így ha belső ponti optimumunk van, akkor a vállalat kínálata a $p$ függvényében:

$$
y(p)=\frac{p}{2} .
$$

Esetleg van olyan ár, ami mellett mégsem ez a kínálat, mert nem is éri meg termelni? Mivel:

$$
\begin{aligned}
& \min _{y} A V C(y)=\min _{y} y, \\
& \min _{y} A V C(y)=0,
\end{aligned}
$$


minden pozitív ár mellett megéri termelni, jó volt a kínálati függvényünk.

b. A maximális haszon $p$ függvényében:

$$
\begin{aligned}
& \Pi(p)=\max _{y}\left\{p \cdot y-y^{2}-36\right\} \\
& \Pi(p)=p \cdot y(p)-y^{2}(p)-36 \\
& \Pi(p)=p \cdot \frac{p}{2}-\left(\frac{p}{2}\right)^{2}-36, \\
& \Pi(p)=\frac{p^{2}}{4}-36 .
\end{aligned}
$$

Ha a piaci ár 10 dollár, akkor ez:

$$
\Pi(10)=\frac{10^{2}}{4}-36=-11 .
$$

c. Az, hogy a munkabér kvázifix költség lett, azt jelenti, hogy 0 kibocsátás mellett a vállalat el tud érni 0 profitot. Termelni csak akkor fog, ha ennél nagyobb profitot tud elérni vele:

$$
\begin{aligned}
\Pi(p) & \geq 0, \\
\frac{p^{2}}{4}-36 & \geq 0, \\
\frac{p^{2}}{4} & \geq 36, \\
p^{2} & \geq 144, \\
p & \geq 12 .
\end{aligned}
$$

A kínálati függvény:

$$
y(p)= \begin{cases}0, & \text { ha } p<12 ; \\ \frac{p}{2}, & \text { ha } p \geq 12 .\end{cases}
$$

Vissza a feladathoz 


\section{9. feladat:}

a. Ha az étterem $p$ ár mellett a profitját pozitív mennyiség termelésével maximalizálja, akkor:

$$
\begin{aligned}
p & =M C(y), \\
p & =2 \cdot y+w, \\
\frac{p-w}{2} & =y .
\end{aligned}
$$

A haszon ekkor:

$$
\begin{aligned}
& \Pi=p \cdot y-y^{2}-w \cdot y-400, \\
& \Pi=(p-w-y) \cdot y-400, \\
& \Pi=\frac{p-w}{2} \cdot \frac{p-w}{2}-400 .
\end{aligned}
$$

A szöveg szerint ez a mostani árak mellett 84 garas, így:

$$
\begin{aligned}
84 & =\frac{p-w}{2} \cdot \frac{p-w}{2}-400, \\
484 & =\left(\frac{p-w}{2}\right)^{2}, \\
44 & =p-w .
\end{aligned}
$$

Ezt majd később felhasználjuk. A másik dolog, amit a szövegből tudunk, az az, hogy ha a szarvashús ára $w^{\prime}=125 \% \cdot w$ lenne, akkor mindegy lenne az étteremnek, hogy pozitív mennyiséget termel-e. Ha nem termel, akkor bevétele nincs, költsége pedig 256 garas, így haszna -256 garas. Mivel mindegy, hogy pozitív mennyiséget termel-e, a pozitív mennyiség mellett elérhetô maximális profit is -256 . A fenti levezetés alapján ekkor az optimális termelés:

$$
y^{\prime}=\frac{p-w^{\prime}}{2},
$$


az ehhez tartozó profit pedig:

$$
\begin{aligned}
\Pi^{\prime} & =\left(p-w^{\prime}-y^{\prime}\right) \cdot y^{\prime}-400, \\
\Pi^{\prime} & =\left(\frac{p-w^{\prime}}{2}\right)^{2}-400, \\
-256 & =\left(\frac{p-w^{\prime}}{2}\right)^{2}-400, \\
24 & =p-w^{\prime} .
\end{aligned}
$$

Korábban levezettük, hogy $44=p-w$, így tudjuk, hogy a $w^{\prime}$ tényezőár 20 garassal magasabb, mint $w$. Ebből:

$$
\begin{aligned}
w^{\prime} & =w+20, \\
125 \% \cdot w & =w+20, \\
25 \% \cdot w & =20, \\
w & =80 .
\end{aligned}
$$

b. A jelenlegi $w$ húsár mellett a fedezeti ponthoz tartozó $\hat{p}$ ár olyan, ami mellett pozitív termeléssel éppen 0 az elérhetô legmagasabb profit. Az előzô pontban levezetettek alapján:

$$
\begin{aligned}
\hat{\Pi} & =\left(\frac{\hat{p}-w}{2}\right)^{2}-400, \\
0 & =\left(\frac{\hat{p}-80}{2}\right)^{2}-400, \\
20 & =\frac{\hat{p}-80}{2}, \\
120 & =\hat{p} .
\end{aligned}
$$


Ezt másik módszerrel, az átlagköltségfüggvény minimális értékeként is megkaphattuk volna:

$$
\begin{gathered}
A C(y)=y+w+\frac{400}{y}, \\
\frac{\mathrm{d} A C(y)}{\mathrm{d} y}=0, \\
1-\frac{400}{y^{2}}=0, \\
20=y, \\
\hat{p}=\min _{y} A C(y), \\
\hat{p}=A C(20)=20+80+\frac{400}{20}=120 .
\end{gathered}
$$

Vissza a feladathoz 
IPARÁGI KÍNÁLAT 
1. feladat: Ha feloldják a korlátozást, akkor az új belépők elversenyzik a bentlévők profitját. Ezért az egy cég által beáldozott maximális 12 garas a mostani profitja. Miután a cégek árelfogadók, ezért a piaci ár egyenlő a határköltségükkel.

$$
a-2(10 y)=12+2 y,
$$

ebból a profitja:

$$
\pi=(12+2 y) y-4-12 y-y^{2}=12 .
$$

a. Megoldva egy cég termelésére kapjuk, hogy:

$$
y=4 \text {, }
$$

amiből a visszahelyettesítés után:

$$
a=100 .
$$

b. Hosszú távú egyensúlyban a cégek az átlagköltségfüggvényük minimumpontjában termelnek, ahol az átlagköltségük megegyezik a határköltségükkel:

$$
\frac{4}{y^{*}}+12+y^{*}=12+2 y^{*},
$$

amiből egy cég termelése:

$$
y^{*}=2 .
$$

A $p=M C$ egyensúlyfeltétel ezek után:

$$
100-2(N * 2)=12+2 * 2,
$$

amiből:

$$
N=21
$$

azaz

$$
21-10=11
$$

új cég lép be.

Vissza a feladathoz 
2. feladat: Egy vállalat optimumfeltétele a

$$
P=M C(y)
$$

egyenlőség, azaz

$$
P=30 q+200
$$

amiből:

$$
q=\frac{P-200}{30} .
$$

A száz darab vállalat ennek százszorosát viszi a piacra, ezért:

$$
Q=100\left(\frac{P-200}{30}\right) .
$$

Az inverz keresleti függvényből nyerjük a keresleti függvényt:

$$
Q=4000-10 P \text {. }
$$

Egyensúlyban a keresett és kínált mennyiség egyenlő:

$$
4000-10 P=100\left(\frac{P-200}{30}\right),
$$

amiből:

$$
P=350, \quad Q=500 \text {. }
$$

Vissza a feladathoz

3. feladat: Az engedélyt megfizető gyártók számára az engedély ellenértéke kvázifix költség. Ebből következően - pozitív termelés esetén - a költségfüggvényük:

$$
c(y)=y^{2}+4 y+100
$$

átlagköltségfüggvényük:

$$
A C(y)=\frac{c(y)}{y}=y+4+\frac{100}{y}
$$

határköltségfüggvényük:

$$
M C(y)=\frac{d c(y)}{d y}=2 y+4 .
$$

Árelfogadó termelők esetén a vállalati optimum szükséges feltétele:

$$
p=M C(y) .
$$


Hosszú távú egyensúlyban a vállalat a fedezeti pontjában termel:

$$
p=A C(y) \text {. }
$$

Ezekből:

$$
A C(y)=y+4+\frac{100}{y}=2 y+4=M C(y),
$$

amiből:

$$
y=10 .
$$

Ezt az értéket visszahelyettesítve:

$$
p=24 \text {. }
$$

Hosszú távú egyensúlyban az egyensúlyi ár mellett a keresett mennyiség egyenlő a kínált mennyiséggel, amit az inverz keresleti függvény

$$
p=124-b \cdot N \cdot y
$$

képletébe beírva

$$
24=124-b \cdot 10 \cdot 10
$$

kapjuk, hogy

$$
b=1 \text {. }
$$

Vissza a feladathoz

4. feladat: Ha egy profitmaximalizáló, árelfogadó vállalat profitja zérus, akkor a fedezeti pontjában termel.

a. Itt

$$
M C(y)=A C(y),
$$

azaz:

$$
c+8 y=\frac{25}{y}+c+4 y
$$

amiből:

$$
y=\frac{5}{2} .
$$

b. Figyelembe véve, hogy egy vállalat ennyit termel, könnyen kiszámíthatjuk az iparági egyensúlyi árat, ha ezt az értéket visszahelyettesítjük az inverz keresleti függvénybe:

$$
p=72-2 * 10 * \frac{5}{2}=22 \text {. }
$$


c. Innen már csak azt kell kihasználnunk, hogy egy profitmaximalizáló, árelfogadó vállalat olyan szinten termel, ahol a határköltsége egyenlő az árral:

$$
M C(y)=c+8 * \frac{5}{2}=22=p,
$$

amiből:

$$
c=2 \text {, }
$$

és:

$$
C_{v}\left(\frac{5}{2}\right)=2 * \frac{5}{2}+4 * \frac{25}{4}=30,
$$

vagy mivel a profit zérus, ezért:

$$
C_{v}(y)=p y-F,
$$

azaz:

$$
C_{v}\left(\frac{5}{2}\right)=22 * \frac{5}{2}-25=30 .
$$

Vissza a feladathoz

\section{5. feladat:}

a. A vállalat profitmaximum-feladata:

$$
\max _{y}\{p \cdot y-C(y)\},
$$

a feladat paraméterei mellett:

$$
\max _{y}\left\{p \cdot y-y^{2}-392 \cdot y-100\right\} .
$$

Ha $y>0$, akkor ezt $y$ szerint maximalizálva (a vállalat a saját kibocsátásról dönt):

$$
\begin{gathered}
\frac{\mathrm{d}\left(p \cdot y-y^{2}-392 \cdot y-100\right)}{\mathrm{d} y}=0, \\
p-2 \cdot y-392=0, \\
\frac{p-392}{2}=y .
\end{gathered}
$$

Ha $p=400$, akkor $y=4$, így a profit:

$$
400 \cdot 4-4^{2}-392 \cdot 4-100=-84 .
$$

Ha $y=0$, akkor a profit 0 (most fix költség nem volt, csak kvázifix). Így ilyen ár mellett az optimális kibocsátás 0 lesz. 
b. Az előző pontbeli levezetés alapján $p$ ár mellett minden egyes vállalat kínálata külön-külön:

$$
y(p)=\frac{p-392}{2} .
$$

(Persze $p<392$ alatt ez nulla.) Így a hat magyar vállalat együttes kínálata:

$$
6 \cdot y(p)=3 \cdot(p-392) \text {. }
$$

A hollandok 300-as ár alatt semmit, fölötte 5000 kilót, épp 300-as áron pedig tetszőleges köztes mennyiséget adnak el, vagyis:

$$
y_{H}(p)=\left\{\begin{array}{cc}
0, & \text { ha } p<300 ; \\
{[0,5000],} & \text { ha } p=300 ; \\
5000, & \text { ha } p>300 .
\end{array}\right.
$$

Így az összesített kínálat:

$$
Y(p)=6 \cdot y(p)+y_{H}(p)=\left\{\begin{array}{cl}
0, & \text { ha } p<300 ; \\
{[0,5000],} & \text { ha } p=300 ; \\
5000, & \text { ha } 392 \geq p>300 ; \\
5000+3 \cdot(p-392), & \text { ha } p \geq 392 .
\end{array}\right.
$$

c. A magyarok $p>392$ felett fognak termelni, ekkor a hollandok már 5000 kilót importálnak. A $p=392$ ár mellett:

$$
D(392)=8040>5000=Y(392) .
$$

Vagyis ekkor még túlkereslet van, az egyensúlyi ár nagyobb lesz mint 392, igény van a magyar termelésre is. Ha $n$ magyar vállalat van a piacon, és $p>392$, akkor az iparági kínálat:

$$
5000+n \cdot(p-392) .
$$

Addig lépnek be/ki magyar vállalatok, amíg a profit pozitív/negatív, így hosszú távú egyensúlyban a magyar vállalatok profitja nulla. (Hogy a hollandoknak miért rögzített 
az 5000 kilós importplafon, azzal most nem foglalkozunk.) Így a magyar vállalatok a fedezeti pontjukban termelnek, ahol $A C(y)$ minimális.

$$
\begin{gathered}
A C(y)=y+392+\frac{100}{y}, \\
\frac{\mathrm{d} A C(y)}{\mathrm{d} y}=0, \\
1-\frac{100}{\left(y^{*}\right)^{2}}=0 \\
\left(y^{*}\right)^{2}=100 \\
y^{*}=10
\end{gathered}
$$

A fedezeti pont azt jelenti, hogy a profit épp nulla, és ez ekvivalens azzal, hogy

$$
p=A C\left(y^{*}\right),
$$

így:

$$
\begin{gathered}
p^{*}=\min _{y} A C(y), \\
p^{*}=10+392+\frac{100}{10}=412 .
\end{gathered}
$$

Egyensúlyban a kereslet megegyezik az iparági kínálattal, így:

$$
\begin{gathered}
D\left(p^{*}\right)=5000+n \cdot\left(p^{*}-392\right), \\
10000-5 \cdot 412=5000+n \cdot(412-392), \\
2940=n \cdot 20, \\
147=n .
\end{gathered}
$$

Vissza a feladathoz 


\section{6. feladat:}

a. Ha egy vállalat nem lép be a piacra, akkor elérhet nulla profitot. Ha belép a piacra, de nem termel, akkor haszna negatív lesz a fix költség miatt. Ha belép a piacra és termel, akkor a haszna:

$$
p \cdot y-C(y)=p \cdot y-y^{2}-100 .
$$

A vállalat a saját kibocsátásról dönt, így aszerint optimalizálva:

$$
\begin{gathered}
\frac{\mathrm{d}\left(p \cdot y-y^{2}-100\right)}{\mathrm{d} y}=0, \\
p-2 \cdot y=0, \\
y(p)=\frac{p}{2} .
\end{gathered}
$$

Ezt visszahelyettesítve a profitba, megkapjuk a profitfüggvényt, amely az adott $p$ ár mellett elérhető legnagyobb hasznot mutatja. Ha a a kibocsátás pozitív, akkor ez:

$$
\begin{gathered}
\Pi(p)=p \cdot y(p)-C(y(p)), \\
\Pi(p)=p \cdot y(p)-y(p)^{2}-100, \\
\Pi(p)=\frac{p^{2}}{2}-\frac{p^{2}}{4}-100, \\
\Pi(p)=\frac{p^{2}}{4}-100 .
\end{gathered}
$$

Ez nagyobb, mint a be nem lépéssel elérhető 0 haszon, ha $p \geq 20$. Így a vállalat által elérhető legnagyobb haszon $p$ függvényében:

$$
\Pi(p)=\left\{\begin{array}{cc}
0, & \text { ha } p<20 \\
\frac{p^{2}}{4}-100, & \text { ha } p \geq 20 .
\end{array}\right.
$$

b. Az a. pontbeli számítások alapján nem fog termelni, ha $p<20$, és $y=\frac{p}{2}$ mennyiséget termel, ha $p \geq 20$, vagyis a kínálati függvény:

$$
y(p)= \begin{cases}0 & \text { ha } p<20 \\ \frac{p}{2} & \text { ha } p \geq 20 .\end{cases}
$$


c. Itt a 100 euró már nem kvázifix, hanem fix költség. Ezért nem termeléssel legfeljebb -100 euró profit érhető el. Kis számolással ebből, vagy rövidebben az $A V C(y)=y$ függvény minimumából azt kapjuk, hogy most már minden nemnegatív ár mellett megéri termelni, így egy a piacra már belépett vállalat kínálati függvénye:

$$
y(p)=\frac{p}{2} .
$$

d. Ha jelenleg tizennyolc vállalat van a piacon, az iparági kínálat:

$$
\begin{aligned}
& Y(p)=18 \cdot y(p) \\
& Y(p)=9 \cdot p .
\end{aligned}
$$

Egyensúlyban a kereslet megegyezik a kínálattal, vagyis:

$$
\begin{aligned}
D\left(p^{*}\right) & =Y\left(p^{*}\right) \\
320-p^{*} & =9 \cdot p^{*} \\
p^{*} & =32 .
\end{aligned}
$$

Emellett egyébként nem nulla a profit, hanem pozitív, ezért ez nem egy hosszú távú egyensúly, újabb vállalatok fognak a piacra lépni.

e. Ha egy vállalat pozitív profitot tud elérni azzal, hogy belép a piacra, akkor be is fog lépni. Ez növeli az iparági kínálatot, ami csökkenti az árakat, egészen addig, amíg végül az új belépők nem lennének nyereségesek. Ezt úgy modellezzük, hogy hosszú távon nulla lesz a vállatok profitja:

$$
\begin{aligned}
\Pi\left(p^{*}\right) & =0, \\
\frac{p^{* 2}}{4}-100 & =0, \\
p^{* 2} & =400, \\
p^{*} & =20 .
\end{aligned}
$$

Ha a piacon egyensúly van, akkor a kereslet egyenlő a kínálattal. Az iparági kínálat a vállalati kínálatok összege, ha $n$ ugyanolyan vállalat van a piacon, akkor az iparági 
kínálat egy vállalat kínálatának az $n$-szerese:

$$
\begin{aligned}
D\left(p^{*}\right) & =Y\left(p^{*}\right), \\
D\left(p^{*}\right) & =n \cdot y\left(p^{*}\right), \\
320-p^{*} & =n \cdot \frac{p^{*}}{2} .
\end{aligned}
$$

Az egyensúlyi árat behelyettesítve:

$$
\begin{aligned}
D(20) & =Y(20), \\
320-20 & =n \cdot \frac{20}{2}, \\
300 & =n \cdot 10, \\
n & =30 .
\end{aligned}
$$

Egy alternatív megoldás a hosszú távú egyensúlyhoz:

Szabad ki- és belépés esetén hosszú távon a vállalatok haszna nulla. Ez azt jelenti, hogy a fedezeti pontban termelnek. Versenyzői vállalatok esetén a fedezeti pontban a határköltséggörbe metszi az átlagköltséggörbét, ${ }^{1}$ azaz:

$$
\begin{gathered}
M C\left(y^{*}\right)=A C\left(y^{*}\right), \\
2 \cdot y^{*}=y^{*}+\frac{100}{y^{*}}, \\
y^{*^{2}}=100, \\
y^{*}=10 .
\end{gathered}
$$

${ }^{1}$ Ez ugye szükséges, de nem elégséges feltétele a fedezeti pontnak. 
A vállalat optimumfeltételéből megkapjuk az egyensúlyi árat is:

$$
\begin{gathered}
p^{*}=M C\left(y^{*}\right), \\
p^{*}=2 \cdot y^{*}, \\
p^{*}=20 .
\end{gathered}
$$

Egyensúlyban a kereslet megegyezik az iparági kínálattal, így:

$$
\begin{gathered}
D\left(p^{*}\right)=n \cdot y^{*}, \\
320-20=n \cdot 10, \\
n=30 .
\end{gathered}
$$

Vissza a feladathoz

\section{7. feladat:}

a. A profitmaximum-feladatból a termelés melletti optimumban:

$$
\begin{gathered}
p \cdot y-C(y)=p \cdot y-\frac{y^{2}}{4}-4, \\
\frac{\mathrm{d}\left(p \cdot y-\frac{y^{2}}{4}-4\right)}{\mathrm{d} y}=0, \\
p-\frac{y}{2}=0,
\end{gathered}
$$

így a kínálat:

$$
y(p)=2 \cdot p
$$

Mivel

$$
\begin{aligned}
& \min _{y} A V C(y)=\min _{y} \frac{y}{2}, \\
& \min _{y} A V C(y)=0,
\end{aligned}
$$

a teljes szakaszon ez a kínálat, nincs olyan rész, ahol jobban megéri nem termelni. 
b. A haszon:

$$
\begin{gathered}
\Pi(p)=p \cdot y(p)-C(y(p)), \\
\Pi(p)=p \cdot y(p)-\frac{(y(p))^{2}}{4}-4, \\
\Pi(p)=y(p) \cdot\left(p-\frac{y(p)}{4}\right)-4, \\
\Pi(p)=2 \cdot p \cdot \frac{p}{2}-4, \\
\Pi(p)=p^{2}-4 .
\end{gathered}
$$

c. Szabad ki- és belépés esetén hosszú távon a vállalatok haszna nulla. Ez azt jelenti, hogy a fedezeti pontban termelnek. Ez az átlagköltségfüggvény minimumában van, azaz:

$$
\begin{gathered}
A C(y)=\frac{y}{4}+\frac{4}{y}, \\
\frac{\mathrm{d} A C(y)}{\mathrm{d} y}=0, \\
\frac{1}{4}-\frac{4}{\left(y^{*}\right)^{2}}=0, \\
\frac{\left(y^{*}\right)^{2}}{4}=4, \\
y^{*}=4, \\
p^{*}=\min _{y} A C(y), \\
p^{*}=\frac{4}{4}+\frac{4}{4}=2 .
\end{gathered}
$$


Egyensúlyban a kereslet megegyezik az iparági kínálattal, így:

$$
\begin{aligned}
D\left(p^{*}\right) & =n \cdot y^{*}, \\
64-2 \cdot 2 & =n \cdot 4, \\
n & =15 .
\end{aligned}
$$

d. Az adót többféleképpen is lehet modellezni. Az egyik módszer az, hogy hozzáadunk $16 \cdot y$-t a vállalat költségéhez. Ezután ugyanazt csináljuk, mint az előző pontokban. Egy másik módszer szerint az adó csak a keresleti függvénynél fog megjelenni, méghozzá a következő formában:

$$
p_{D}=p_{S}+16 .
$$

Az adó bevezetése után rövid távon a vállalatok száma változatlan, 15. Így a rövid távú egyensúlyban:

$$
\begin{gathered}
D\left(p_{D}\right)=Y\left(p_{S}\right), \\
D\left(p_{D}\right)=n \cdot y\left(p_{S}\right), \\
64-2 \cdot p_{D}=15 \cdot 2 \cdot p_{S}, \\
64-2 \cdot\left(p_{S}+16\right)=30 \cdot p_{S}, \\
p_{S}=1 p_{D}=17 .
\end{gathered}
$$

Vagyis rövid távon 15 egységgel nő a fogyasztói ár.

e. Hosszú távon a termelők profitja nulla lesz. A termelőket csak az a $p_{S}$ ár érdekli, amit ők kapnak a termékért, ezért:

$$
\begin{aligned}
\Pi\left(p_{S}\right) & =0, \\
p_{S}^{2}-4 & =0, \\
p_{S} & =2 .
\end{aligned}
$$

A fogyasztói ár ekkor $p_{D}=2+16=18$. Itt már meg is állhatunk, válaszoltunk a kérdésre. Ha valakit érdekel, hogy hány rózsatermelő marad hosszú távon: 
A piacon a fogyasztók által érzékelt ár mellett a kereslet egyenlő a vállalatok által érzékelt ár melletti kínálattal:

$$
\begin{aligned}
D(18) & =Y(2), \\
64-2 \cdot 18 & =n \cdot 2 \cdot 2, \\
28 & =n \cdot 4, \\
n & =7 .
\end{aligned}
$$

Vissza a feladathoz

\section{8. feladat:}

a. A profitmaximum-feladatból a termelés melletti optimumban:

$$
\begin{gathered}
p \cdot y-C(y)=p \cdot y-40 \cdot y-y^{2}-100, \\
\frac{\mathrm{d}\left(p \cdot y-40 \cdot y-y^{2}-100\right)}{\mathrm{d} y}=0, \\
p-40-2 \cdot y=0,
\end{gathered}
$$

így a kínálat:

$$
y(p)=\frac{p-40}{2}
$$

Mivel

$$
\begin{aligned}
& \min _{y} A V C(y)=\min _{y} y+40, \\
& \min _{y} A V C(y)=40,
\end{aligned}
$$


a kínálat $p<40$ mellett nulla, de az igazából az $y(p)=\frac{p-40}{2}$ képletből is látszott. A profitfüggvény:

$$
\begin{gathered}
\Pi(p)=p \cdot y(p)-40 \cdot y(p)-y^{2}(p)-100, \\
\Pi(p)=y(p) \cdot(p-40-y(p))-100, \\
\Pi(p)=\frac{(p-40)^{2}}{4}-100 .
\end{gathered}
$$

Ha egy vállalat pozitív profitot tud elérni azzal, hogy belép a piacra, akkor be is fog lépni. Ez növeli az iparági kínálatot, ami csökkenti az árakat, egészen addig, amíg végül az új belépők nem lennének nyereségesek. Ezt úgy modellezzük, hogy hosszú távon nulla lesz a vállatok profitja:

$$
\begin{gathered}
\Pi\left(p^{*}\right)=0, \\
\frac{\left(p^{*}-40\right)^{2}}{4}-100=0, \\
\left(p^{*}-40\right)^{2}=400, \\
p^{*}=60 .
\end{gathered}
$$

b. Ha a piacon egyensúly van, akkor a kereslet egyenlő a kínálattal. Az iparági kínálat a vállalati kínálatok összege, ha $n$ ugyanolyan vállalat van a piacon, akkor az iparági kínálat egy vállalat kínálatának az $n$-szerese.

$$
\begin{aligned}
D\left(p^{*}\right) & =Y\left(p^{*}\right), \\
200-\frac{1}{2} \cdot p^{*} & =n \cdot y\left(p^{*}\right), \\
200-\frac{1}{2} \cdot p^{*} & =n \cdot \frac{p^{*}-40}{2}, \\
200-\frac{60}{2} & =n \cdot \frac{20}{2}, \\
n & =17 .
\end{aligned}
$$


c. A fix költség megváltozása nem befolyásolja kínálati függvényt:

$$
\begin{gathered}
M C(y)=p, \\
2 \cdot y+40=p, \\
y(p)=\frac{p-40}{2} .
\end{gathered}
$$

Így rövid távú egyensúlyban, ahol a közgazdászok száma még nem változott, vagyis az előző pontban szereplő 17, az iparági kínálat megegyezik a korábbival. A keresleti függvény sem változott, így az egész egyensúly ugyanaz, mint korábban. Vagyis $p^{*}=$ 60, az ár változatlan.

d. A fix költség megváltozása a profitot viszont csökkenti 300 garassal, így:

$$
\Pi(p)=\frac{(p-40)^{2}}{4}-400 .
$$

Szabad ki- és belépés mellett hosszú távú egyensúlyban:

$$
\begin{gathered}
\Pi\left(p^{*}\right)=0, \\
\frac{\left(p^{*}-40\right)^{2}}{4}-400=0, \\
p^{*}=80 .
\end{gathered}
$$

A piac akkor lesz ilyen ár mellett egyensúlyban, ha:

$$
\begin{aligned}
D(80) & =Y(80), \\
200-\frac{80}{2} & =n \cdot \frac{80-40}{2}, \\
n & =8 .
\end{aligned}
$$

Vissza a feladathoz 


\section{9. feladat:}

a. A profitmaximum-feladatból a termelés melletti optimumban:

$$
\begin{gathered}
p \cdot y-C(y)=p \cdot y-y^{2}-F, \\
\frac{\mathrm{d}\left(p \cdot y-y^{2}-F\right)}{\mathrm{d} y}=0, \\
p-2 \cdot y=0,
\end{gathered}
$$

így a kínálat:

$$
y(p)=\frac{p}{2}
$$

A profitfüggvény:

$$
\begin{gathered}
\Pi(p)=p \cdot y(p)-y^{2}(p)-F, \\
\Pi(p)=y(p) \cdot(p-y(p))-F, \\
\Pi(p)=\frac{p^{2}}{4}-F .
\end{gathered}
$$


Szabad ki- és belépés mellett hosszú távú egyensúlyban a profit nulla, így:

$$
\begin{gathered}
\Pi(p)=0, \\
\frac{p^{2}}{4}-F=0, \\
p^{* 2}=4 \cdot F, \\
p^{*}=2 \cdot \sqrt{F}, \\
D\left(p^{*}\right)=Y\left(p^{*}\right), \\
100-p^{*}=n \cdot \frac{2 \cdot p^{*}}{2}, \\
100-2 \cdot \sqrt{F}=n \cdot \sqrt{F} .
\end{gathered}
$$

A taxisok száma $F$ függvényében:

$$
n(F)=\frac{100}{\sqrt{F}}-2 .
$$

b. Az önkormányzat bevétele taxisonként $F$, így az összbevétel $n \cdot F$. Ezt szeretnénk $F$ szerint maximalizálni:

$$
\begin{gathered}
n(F) \cdot F=\frac{100}{\sqrt{F}} \cdot F-2 \cdot F=100 \cdot \sqrt{F}-2 \cdot F, \\
\frac{\mathrm{d} n(F) \cdot F}{\mathrm{~d} F}=\frac{100}{2 \cdot \sqrt{F}}-2=0, \\
50=2 \cdot \sqrt{F}, \\
625=F .
\end{gathered}
$$

Egyébként ekkor csak két taxis van New Yorkban, az egyensúlyi ár 50 dollár és fejenként 25 fuvart vállalnak.

Vissza a feladathoz 


\section{0. feladat:}

a. A szöveg szerint egy Japánban értékesítést végző vállalat teljes költségfüggvénye:

$$
C(y)=y^{2}+40 \cdot y+25 .
$$

Szabad ki- és belépés esetén hosszú távon a vállalatok haszna 0 . Ez azt jelenti, hogy a fedezeti pontban termelnek. Versenyzői vállalatok esetén fedezeti pontban a határköltséggörbe metszi az átlagköltséggörbét, azaz:

$$
\begin{gathered}
M C\left(y^{*}\right)=A C\left(y^{*}\right), \\
2 \cdot y^{*}+40=y^{*}+40+\frac{25}{y^{*}}, \\
y^{*}=\frac{25}{y^{*}}, \\
y^{*}=5, \\
p^{*}=M C\left(y^{*}\right)=M C(5)=2 \cdot 5+40=50 .
\end{gathered}
$$

b. Egyensúlyban a kereslet megegyezik az iparági kínálattal:

$$
\begin{gathered}
D\left(p^{*}\right)=Y\left(p^{*}\right), \\
D(50)=n \cdot 5, \\
140-50=n \cdot 5, \\
n=18 .
\end{gathered}
$$

A csatorna megépítését követôen a költségfüggvény:

$$
C(y)=y^{2}+20 \cdot y+25
$$


lenne. Emellett tetszőleges vállalat kínálati függvénye:

$$
\begin{gathered}
M C(y)=p, \\
2 \cdot y+20=p, \\
y(p)=\frac{p-20}{2}, \\
\min _{y} A V C(y)=\min _{y} 20+y, \\
\min _{y} A V C(y)=20 .
\end{gathered}
$$

Rövid távon a vállalatok száma változatlan (ez egyébként valóságban erôsen megkérdőjelezhető, mert a csatorna megépítése nem hirtelen, így nem váratlan), így egyensúlyban:

$$
\begin{gathered}
D\left(p^{*}\right)=Y\left(p^{*}\right), \\
140-p^{*}=18 \cdot \frac{p-20}{2}, \\
p^{*}=32 .
\end{gathered}
$$

Hosszú távon ismét addig lépnek be új vállalatok, amíg el nem versenyzik a profitot. Ekkor újra a fedezeti pontban zajlik a termelés, vagyis:

$$
\begin{gathered}
M C\left(y^{*}\right)=A C\left(y^{*}\right), \\
2 \cdot y^{*}+20=y^{*}+20+\frac{25}{y^{*}}, \\
y^{*}=\frac{25}{y^{*}}, \\
y^{*}=5, \\
p^{*}=M C\left(y^{*}\right)=M C(5)=2 \cdot 5+20=30 .
\end{gathered}
$$


c. Mivel a határköltség lineáris, a termelői többletet tudjuk háromszög területeként számolni. Tetszőleges vállalat termelői többlete tetszőleges $p$ ár mellett:

$$
T T(p)=\frac{(p-M C(0)) \cdot y(p)}{2} .
$$

Csatorna nélkül, a csatorna nélküli $p=50$ egyensúlyi ár mellett ez:

$$
\begin{gathered}
T T(50)=\frac{(50-M C(0)) \cdot y(50)}{2}, \\
T T(50)=\frac{(50-40) \cdot 5}{2}, \\
T T(50)=25 .
\end{gathered}
$$

De nem 1, hanem 18 vállalat van, így az ágazat termelői többlete $18 \cdot 25=450$. Tetszőleges vállalat termelői többlete tetszőleges $p$ ár mellett, csatornával:

$$
\begin{aligned}
& T T(p)=\frac{(p-M C(0)) \cdot y(p)}{2}, \\
& T T(p)=\frac{(p-20) \cdot \frac{p-20}{2}}{2}, \\
& T T(p)=\frac{(p-20)^{2}}{4} .
\end{aligned}
$$

Az építkezés utáni rövid távú egyensúlyban $p=32$, így a termelői többlet vállalatonként 36 , az ágazat egészének $18 \cdot 36=648$. A hosszú távú egyensúlyban $p=30$, így egy vállalat többlete 25 , az egész iparág többlete pedig $22 \cdot 25=550$. A többletváltozás 198 dollár rövid távon, 100 dollár hosszú távon.

Vissza a feladathoz 
TERMELÉS 
1. feladat: Ha egész áldott nap dolgozunk, akkor az egész napra vonatkozó transzformációs görbén kell pontot választanunk. Miután én egy nap akár 15 alakot is kifaragok, ha egész nap dolgozom és pontosan 10 felöltöztetett babát kell előállítanunk, akkor biztosan öltözetet is készítek.

Innen két úton is mehetünk tovább. Az egyszerúbb:

Ha egy öltözetet készítek, akkor arra egyharmad napom megy rá, ez épp elég a 10 alak megfaragásához. Ekkor Lusta Anna - egész nap dolgozva - éppen elkészítheti a többi ruhát. A többi lány rövidebb idő alatt készít el 9 öltözetet, ezért ők lazsálnának. Emiatt csak Anna foglalkoztatása jöhet szóba. Ha két vagy három ruhát csinálok, akkor pontosan kétharmad vagy egész napomba kerül a dolog, ami alatt a maximálisan kifaragható alakok száma 6, illetve 1 lehet. Ekkor nem tudjuk az előírt 10 felöltöztetett madárijesztőt elkészíteni.

A ,bonyolultabb" út:

Ha Annát kérem meg, akkor a transzformációs függvényünk (a ruha van a vízszintes tengelyen):

$$
a= \begin{cases}16-\frac{1}{9} r, & \text { ha } \quad r \leqq 9 \\ 60-5 r, & \text { ha } 9<r \leqq 12 .\end{cases}
$$

Ha Borcsát, akkor:

$$
a=\left\{\begin{array}{cl}
16-\frac{1}{10} r, & \text { ha } r \leqq 10 \\
65-5 r, & \text { ha } 10<r \leqq 13
\end{array}\right.
$$

Ha Cilit, akkor:

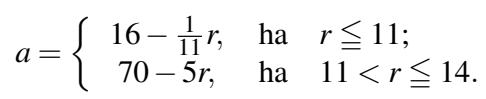

Azt kell megvizsgálnuk, melyik függvény metszi az

$$
a=r
$$

egyenest az

$$
r=10
$$

értéknél. Nyilván Annáé.

Vissza a feladathoz

2. feladat: Először az egy órára vonatkozó, együttes transzformációs görbe egyenletét adjuk meg. (A fej van a vízszintes tengelyen.)

$$
n y=\left\{\begin{array}{l}
25-\frac{5}{8} f, \text { ha } f \leqq 8 \\
36-2 f, \text { ha } f>8 .
\end{array}\right.
$$

Másodszor vegyük észre, hogy miután egy tomahawkhoz egy fej és egy nyél kell, ezért:

$$
f=n y .
$$


Ebből következően a transzformációs görbe meredekebb szakaszán kell keresni a metszéspontot, azaz:

$$
f=36-2 f
$$

amiből:

$$
f=12 \text {. }
$$

Miután ez egy órai mennyiség, ezért nyolc óra alatt nyolcszor ennyi tomahawkot tudnak előállítani:

$$
t=8 * f=96 .
$$

Vissza a feladathoz

\section{3. feladat:}

a. A könnyưipar termelési függvénye tôkében és munkában is növekvő, így a kibocsátása akkor maximális, ha minden erőforrást felhasznál. A maximális kibocsátása:

$$
F_{1}(400,100)=\sqrt{400 \cdot 100}=200 .
$$

Ekkor a szolgáltató szektornak semmi erőforrás nem marad, a gazdaság teljes kibocsátása a $(200,0)$ vektorral írható le.

b. Hasonlóképpen a szolgáltató szektor maximális kibocsátása:

$$
F_{2}(400,100)=4 \cdot \sqrt{400 \cdot 100}=800 .
$$

Ekkor a könnyưiparnak semmi erőforrás nem marad, a gazdaság teljes kibocsátása a $(0,8000)$ vektorral írható le.

c. A szöveg alapján:

$$
\begin{aligned}
& q_{1}=\sqrt{K_{1} \cdot L_{1}}, \\
& q_{2}=4 \cdot \sqrt{K_{2} \cdot L_{2}} .
\end{aligned}
$$

A kibocsátásokat az erőforrások mennyisége korlátozza, konkrétan:

$$
\begin{aligned}
K_{1}+K_{2} & \leq 400 \\
L_{1}+L_{2} & \leq 100 .
\end{aligned}
$$


Mivel a termelési függvények monoton növekvőek mind tôkében, mind munkában, csak akkor nem növelhető a kibocsátás, ha minden erőforrást felhasználunk. Így ezek az erőforráskorlátok egyenlőségre teljesülnek. Vagyis:

$$
\begin{aligned}
& K_{2}=400-K_{1}, \\
& L_{2}=100-L_{1} .
\end{aligned}
$$

A termelés akkor is növelhető, ha nem egyeznek meg a helyettesítési határarányok. (Amennyiben belsô pontban vagyunk.) Így a hatékony termelés további feltétele:

$$
\begin{aligned}
\left|\operatorname{MRTS}_{1}\left(K_{1}, L_{1}\right)\right| & =\left|\operatorname{MRTS} S_{2}\left(K_{2}, L_{2}\right)\right|, \\
\frac{L_{1}}{K_{1}} & =\frac{L_{2}}{K_{2}}, \\
K_{2} & =\frac{K_{1}}{L_{1}} \cdot L_{2} .
\end{aligned}
$$

Ebbe behelyettesítve a $K_{2}$-re és $L_{2}$-re kapott összefüggéseket:

$$
\begin{gathered}
K_{2}=\frac{K_{1}}{L_{1}} \cdot L_{2}, \\
400-K_{1}=\frac{K_{1}}{L_{1}} \cdot\left(100-L_{1}\right), \\
400 \cdot L_{1}-K_{1} \cdot L_{1}=100 \cdot K_{1}-K_{1} \cdot L_{1}, \\
400 \cdot L_{1}=100 \cdot K_{1}, \\
4 \cdot L_{1}=K_{1} .
\end{gathered}
$$

Vagyis a termelés csak akkor hatékony, ha az elsô ágazatban négyszer annyi tôkét használnak fel, mint munkaerőt, a maradék erőforrásokat pedig a második ágazatban használják fel. Egy szabadságfok maradt. Lényegében $L_{1}$-rôl (vagy $K_{1}$-rôl, vagy $L_{2}$-rôl vagy $K_{2}$-ról) szabadon dönthetünk, de ez minden mást meghatároz: $K_{1}$-t, $K_{2}$-t, $L_{2}$-t, $q_{1}$-t és 
$q_{2}$-t is. Konkrétan:

$$
\begin{gathered}
\frac{K_{1}}{L_{1}}=4, \\
K_{2}=\frac{K_{1}}{L_{1}} \cdot L_{2}, \\
K_{2}=4 \cdot L_{2},
\end{gathered}
$$

így:

$$
\begin{gathered}
q_{1}=\sqrt{K_{1} \cdot L_{1}}, \\
q_{1}=\sqrt{4 \cdot L_{1} \cdot L_{1}}, \\
q_{1}=2 \cdot L_{1}, \\
q_{2}=4 \cdot \sqrt{K_{2} \cdot L_{2}}, \\
q_{2}=4 \cdot \sqrt{4 \cdot L_{2} \cdot L_{2}}, \\
q_{2}=8 \cdot L_{2} .
\end{gathered}
$$

Ugyanakkor

$$
L_{1}+L_{2}=100
$$

így:

$$
\begin{aligned}
L_{1}+L_{2} & =100 \\
\frac{q_{1}}{2}+\frac{q_{2}}{8} & =100 .
\end{aligned}
$$

Ez a termelési lehetőségek halmazának határát implicit módon meghatározó függvény, mivel az egyenlőséget teljesítő $\left(q_{1}, q_{2}\right)$ pontok a hatékony kibocsátáspárok. Ha szeret- 
nénk $q_{2}$-t a $q_{1}$ közvetlen függvényeként meghatározni:

$$
\begin{aligned}
& \frac{q_{1}}{2}+\frac{q_{2}}{8}=100, \\
& 4 \cdot q_{1}+q_{2}=800, \\
& q_{2}=800-4 \cdot q_{1} .
\end{aligned}
$$

Vissza a feladathoz

\section{4. feladat:}

a. A termelési lehetőségek halmazát leíró implicit függvény:

$$
f(x, y)=25 \cdot x^{2}+y^{2}-2000=0,
$$

így:

$$
|M R T(x, y)|=\frac{2 \cdot x}{2 \cdot y}=\frac{x}{y} .
$$

A megadott kibocsátás mellett:

$$
|\operatorname{MRT}(4,40)|=\frac{1}{10} .
$$

A helyettesítési határarányok pedig:

$$
\begin{aligned}
\left|\operatorname{MRS}_{A}(3,1)\right| & =\frac{4}{3}, \\
\left|\operatorname{MRS}_{B}(30,10)\right| & =\frac{4}{3} .
\end{aligned}
$$

b. Egy belsố ponti $\left(x_{A}, y_{A}, x_{B}, y_{B}\right)$ fogyasztási vektor és az általa meghatározott $(x, y)$ kibocsátásvektor akkor Pareto-hatékony, ha a kibocsátás lehetséges és hatékony, valamint:

$$
\operatorname{MRT}(x, y)=\operatorname{MRS}_{A}\left(x_{A}, y_{A}\right)=\operatorname{MRS}_{B}\left(x_{B}, y_{B}\right)
$$


Mivel:

$$
\begin{aligned}
\left|\operatorname{MRS}_{A}\left(x_{A}, y_{A}\right)\right| & =\left|M R S_{B}\left(x_{B}, y_{B}\right)\right|, \\
4 \cdot \frac{y_{A}}{x_{A}} & =4 \cdot \frac{y_{B}}{x_{B}}, \\
\frac{y_{A}}{x_{A}} & =\frac{y_{B}}{x_{B}}, \\
\frac{y_{A}}{x_{A}} & =\frac{y-y_{A}}{x-x_{A}}, \\
x \cdot y_{A}-y_{A} \cdot x_{A} & =y \cdot x_{A}-y_{A} \cdot x_{A}, \\
x \cdot y_{A} & =y \cdot x_{A}, \\
\frac{x}{y} & =\frac{x_{A}}{y_{A}} .
\end{aligned}
$$

Ugyanakkor:

$$
\begin{aligned}
\left|\operatorname{MRS}_{A}\left(x_{A}, y_{A}\right)\right| & =|\operatorname{MRT}(x, y)|, \\
4 \cdot \frac{y_{A}}{x_{A}} & =25 \cdot \frac{x}{y}, \\
\frac{4}{25} \cdot \frac{y}{x} & =\frac{x_{A}}{y_{A}}
\end{aligned}
$$

A két egyenlőségből:

$$
\frac{x}{y}=\frac{x_{A}}{y_{A}}=\frac{4}{25} \cdot \frac{y}{x},
$$

így:

$$
25 \cdot x^{2}=4 \cdot y^{2} .
$$


Ezt behelyettesítve a termelési lehetőségek halmazát leíró implicit függvénybe azt kapjuk, hogy:

$$
\begin{gathered}
25 \cdot x^{2}+y^{2}-2000=0, \\
4 \cdot y^{2}+y^{2}=2000, \\
y^{2}=400, \\
y=20, x=8 .
\end{gathered}
$$

Csak e mellett a termelés mellett lehetséges Pareto-hatékony fogyasztás, és minden olyan fogyasztás Pareto-hatékony, ahol $0 \leq x_{A} \leq 8$ és:

$$
\begin{aligned}
& y_{A}=\frac{5}{2} \cdot x_{A}, \\
& x_{B}=8-x_{A}, \\
& y_{B}=20-y_{A} .
\end{aligned}
$$

Vissza a feladathoz

\section{5. feladat:}

a. Először vizsgáljuk meg külön Robinson és külön Péntek termelési lehetőségeinek a halmazát. Ha minden idejét halászattal tölti, Robinson 18 halat tud fogni. Ha minden idejében kókuszt szed, akkor 9 kókuszdiót gyújthet. Ezeknek bármilyen konvex kombinációját is előallíthatja, így a termelési lehetőségeinek halmaza a $(H, K)$ koordináta-rendszerben egy háromszög. Robinson transzformációs rátája $-\frac{1}{2}$, vagyis azzal, hogy lemond egy halról, fél kókuszdióval többet szerezhet. Péntek legfeljebb 18 halat vagy 6 kókuszdiót termelhet, és transzformációs rátája $-\frac{1}{3}$. Az aggregált termelési lehetőségek halmazát a komparatív előnyök logikája alapján tudjuk megszerkeszteni. Ha mindenki csak halat termel, összesen 36 hal és 0 kókuszdió lesz a kibocsátás. Ha szeretnének egy kevés kókuszdiót is termelni, úgy érhető el maximális kibocsátás, ha ezt mind Robinson termeli, mivel azzal, hogy egy halról lemond (mert valamennyi időt inkább kókuszszedésre szán) ô több kókuszdiót szerez, mintha Péntek mondana le egy hal termeléséről. Így a termelési lehetőségek halmazának egyik határa egy $(36,0)$ pontból kiinduló - $\frac{1}{2}$ meredekségú szakasz. Ez azonban csak addig mutatja a termelési lehetőségeket, amíg Robinsonnak van még átcsoportosítható ideje. Ha már minden idejében kókuszt szed, akkor a gazdaság nem szerezhet még fél kókuszt egy halról való 
lemondással, mivel ennek a halnak a kifogásáról már csak Péntek mondhat le, és ô csak egyharmad kókuszt szerezhet helyette. Így a termelési lehetőségek halmazának határa megtörik abban a pontban, ahol Péntek csak halat fog és Robinson csak kókuszt szed. Ez a $(18,9)$ pont. Ettől a ponttól balra (amikor kevesebb halat és még több kókuszt termel a gazdaság) a transzformációs ráta $-\frac{1}{3}$. Ez megy $(0,15)$ pontig, ahol mindenki már csak halat termel. Gyors koordinátageometriai ellenőrzés: Tényleg összeköti egy $-\frac{1}{2}$ meredekségú egyenes $(36,0)$ és $(18,9)$, illetve egy $-\frac{1}{3}$ meredekségú egyenes a $(18,9)$ és $(0,15)$ pontokat?

$$
\begin{aligned}
& \frac{1}{2} \cdot 36+0=\frac{1}{2} \cdot 18+9 \\
& \frac{1}{3} \cdot 18+9=\frac{1}{3} \cdot 0+15
\end{aligned}
$$

úgyhogy igen. Vagyis az aggregált termelési lehetőségek halmaza a $(0,0),(36,0)$, $(18,9)$ és $(0,15)$ pontok által határolt négyszög. Ezt nem kell lerajzolni, de azért itt van:

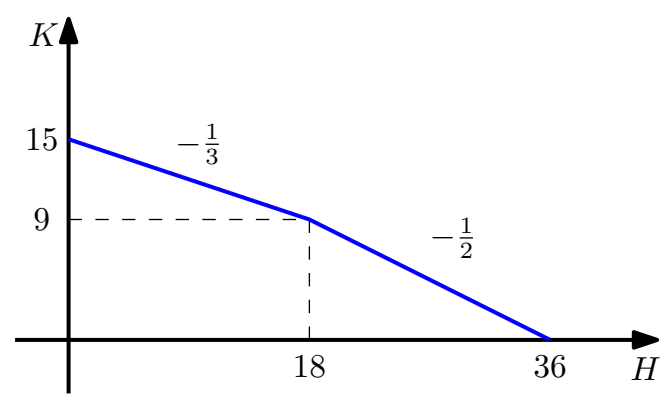

b. Jelöljük a kibocsátást $\left(y_{H}, y_{K}\right)$-val. Mivel csak a megtermelt jószágokat lehet elfogyasztani:

$$
\begin{aligned}
& y_{H}=H_{R}+H_{P}, \\
& y_{K}=K_{R}+K_{P} .
\end{aligned}
$$

Rövid esetvizsgálatra lesz szükség, ebben ötfajta hatékony termelést fogunk megkülönböztetni. A $(36,0)$ pontot, a $(36,0)$ és $(18,9)$ pontokat összekötő szakasz belsejében lévő pontokat, a $(18,9)$ pontot, a $(18,9)$ és $(0,15)$ pontokat összekötő szakasz belsejében lévő pontokat és $(0,15)$ pontot. A fogyasztás nem lehet Pareto-hatékony, ha az összkibocsátás $(36,0)$ vagy $(0,15)$, mivel ezek mellett mindkét fogyasztó nulla mennyiséget 
fogyaszt valamelyik jószágból, így nulla hasznossággal rendelkezik, pedig kicsit pozitív hasznosság nyilvánvalóan elérhető lenne, például lehetséges a $(2,2)$ kibocsátás és az ebből megvalósítható $(1,1,1,1)$ fogyasztási vektor. Ezeket a pontokat nem is vizsgáljuk hát tovább.

I. eset

Ha a kibocsátás egy a $(36,0)$ és $(18,9)$ pontokat összekötő szakasz belsejében lévő $\left(y_{H}, y_{K}\right)$ pont, akkor igaz, hogy:

$$
\frac{1}{2} \cdot y_{H}+y_{K}=\frac{1}{2} \cdot 36+0=18
$$

Ekkor a transzformációs határráta $-\frac{1}{2}$. Ezt később fel tudjuk majd használni, hiszen a hasznosságfüggvények most olyanok, hogy belsô ponti fogyasztás mellett mindig létezik a helyettesítési határarány, és így csak akkor lehet belső ponti fogyasztás Paretohatékony, ha a helyettesítési határarány megegyezik a transzformációs rátával.

II. eset

Ha a kibocsátás egy a $(18,9)$ és $(0,15)$ pontokat összekötő szakasz belsejében lévő $\left(y_{H}, y_{K}\right)$ pont, akkor igaz, hogy:

$$
\frac{1}{3} \cdot y_{H}+y_{K}=\frac{1}{2} \cdot 0+15=15 \text {. }
$$

Ekkor a transzformációs határráta $-\frac{1}{3}$.

III. eset

Végül lehetséges, hogy a kibocsátás az $\left(y_{H}, y_{K}\right)=(18,9)$ pont. Ebben a pontban nem létezik a transzformációs határráta, mivel más értéket venne fel, ha több halat, és mást, ha több kókuszdiót szeretnénk. Szerencsére azzal, hogy nem csak bemagoltuk az $|M R T|=|M R S|$ kifejezést, itt is tudunk mondani valamit a Pareto-hatékony fogyasztásról. Ha egy fogyasztó helyettesítési határarányának az abszolút értéke nagyobb lenne, mint $\frac{1}{2}$, az az jelenti, hogy többre értékel két (marginális) halat, mint egy (marginális) kókuszdiót. Márpedig a termelés lehetővé teszi két újabb hal előállítását egy kókuszdió árán. Ezzel lehetséges lenne egy Pareto-javítás, ami azt jelenti, hogy a fogyasztás nem lehet Pareto-hatékony. Így a $(18,9)$ termelés csak akkor tartozhat Pareto-hatékony fogyasztáshoz, ha egyik fogyasztó helyettesítési határarányának abszolút értéke sem nagyobb, mint $\frac{1}{2}$. Hasonlóképpen nem lehet a helyettesítési határarányok abszolút értéke kisebb, mint $\frac{1}{3}$, mivel ekkor Pareto-javítás érhető el azzal, hogy erőforrásokat csoportosítanak át kókusztermelésre. Vagyis ha a $\left(H_{R}, K_{R}, H_{P}, K_{P}\right)$ Pareto-hatékony fogyasztáshoz az $\left(y_{H}, y_{K}\right)=(18,9)$ kibocsátás tartozik, akkor:

$$
\begin{aligned}
& \frac{1}{3} \leq\left|M R S_{R}\left(H_{R}, K_{R}\right)\right| \leq \frac{1}{2}, \\
& \frac{1}{3} \leq\left|M R S_{P}\left(H_{P}, K_{P}\right)\right| \leq \frac{1}{2} .
\end{aligned}
$$


Most, hogy sikerült felvázolni a lehetőségeket, itt az idő, hogy megnézzük, melyik eset áll fent. Az I. esetben

$$
\left|M R T\left(y_{H}, y_{K}\right)\right|=\left|M R S_{R}\left(H_{R}, K_{R}\right)\right|=\left|M R S_{P}\left(H_{P}, K_{P}\right)\right|,
$$

vagyis:

$$
\begin{aligned}
\frac{1}{2} & =2 \cdot \frac{K_{R}}{H_{R}}, \\
H_{R} & =4 \cdot K_{R},
\end{aligned}
$$

illetve:

$$
\begin{aligned}
\frac{1}{2} & =2 \cdot \frac{K_{P}}{H_{P}}, \\
H_{P} & =4 \cdot K_{P} .
\end{aligned}
$$

Ebből:

$$
\begin{gathered}
y_{H}=H_{R}+H_{P}, \\
y_{H}=4 \cdot K_{R}+4 \cdot K_{P}, \\
y_{H}=4 \cdot\left(K_{R}+K_{P}\right), \\
y_{H}=4 \cdot y_{K} .
\end{gathered}
$$

Ebből és az I. eset termeléseihez tartozó

$$
\frac{1}{2} \cdot y_{H}+y_{K}=18
$$

egyenlőségből kapjuk, hogy:

$$
y_{K}=6, \quad y_{H}=24 .
$$

Ellenőriznünk kell, hogy ez valóban az I. esetbe tartozó kibocsátás-e, vagyis tényleg a $(18,9)$ és $(36,0)$ pontok közé esik-e. Szerencsére igen, mivel $18 \leq y_{H} \leq 36$. Így minden olyan fogyasztás Pareto-hatékony, amelyre $0 \leq K_{R} \leq 6$, és:

$$
\begin{aligned}
& H_{R}=4 \cdot K_{R}, \\
& K_{P}=6-K_{R}, \\
& H_{P}=24-H_{R} .
\end{aligned}
$$


A többi esetben vajon lesz Pareto-hatékony megoldás? ${ }^{1}$ A II. esetben:

$$
\begin{aligned}
\frac{1}{3} & =2 \cdot \frac{K_{R}}{H_{R}}, \\
H_{R} & =6 \cdot K_{R}, \\
\frac{1}{3} & =2 \cdot \frac{K_{P}}{H_{P}}, \\
H_{P} & =6 \cdot K_{P}, \\
H_{R}+H_{P} & =6 \cdot K_{P}+6 \cdot K_{P}, \\
y_{H} & =6 \cdot y_{K},
\end{aligned}
$$

és felhasználva emellett a II. eset termeléseihez tartozó

$$
\frac{1}{3} \cdot y_{H}+y_{K}=15
$$

egyenlőséget, azt kapjuk hogy:

$$
y_{K}=5, \quad y_{H}=30 .
$$

Ez azonban nem a II. esetbe tartozó kibocsátás, nem esik a $(18,9)$ és $(0,15)$ pontok közé, mivel $y_{H}>18$. Így a II. esetben nem lehetséges Pareto-hatékony kibocsátás. A III. esetben kicsit máshogy járunk el, mint eddig. Ekkor $\left(y_{H}, y_{K}\right)=(18,9)$. A Paretohatékonyság miatt a helyettesítési határarányok (belső pontban) megegyeznek. Jelöljük ezek abszolút értékét röviden $\lambda$-val, vagyis:

$$
\begin{gathered}
\lambda=\left|M R S_{R}\left(H_{R}, K_{R}\right)\right|=\left|M R S_{P}\left(H_{P}, K_{P}\right)\right|, \\
\lambda=2 \cdot \frac{K_{R}}{H_{R}}=2 \cdot \frac{K_{P}}{H_{P}} .
\end{gathered}
$$

Ebből következik az

$$
\begin{aligned}
& 2 \cdot K_{P}=\lambda \cdot H_{P}, \\
& 2 \cdot K_{R}=\lambda \cdot H_{R}
\end{aligned}
$$

${ }^{1}$ Nem lesz, mert a termelési lehetőségek halmaza konvex és a hasznosságfüggvény szigorúan konvex. De be kéne bizonyítani, hogy ebből következik, hogy csak egy optimális termelés van, és ezt nem szeretnénk. 
egyenletrendszer. (Egyébként ez most akkor is igaz, ha a fogyasztás Pareto-hatékony, de nem belsô ponti.) Ebből:

$$
\begin{aligned}
2 \cdot K_{P}+2 \cdot K_{R} & =\lambda \cdot H_{P}+\lambda \cdot H_{R}, \\
2 \cdot y_{K} & =\lambda \cdot y_{H} .
\end{aligned}
$$

Mivel a III. esetben $y_{H}=18, y_{K}=9$, a $\lambda$ érték nem más, mint:

$$
\lambda=\frac{2 \cdot y_{K}}{y_{H}}=1 .
$$

De ez ellentmond a III. eset azon feltételének, hogy ekkor a helyettesítési határarányok abszolút értéke $\frac{1}{3}$ és $\frac{1}{2}$ közé esik. Így ez sem Pareto-hatékony fogyasztás.

A b. pont megoldása véget ért. Most viszonylag szerencsénk volt, pont az I. esetben megtaláltuk a Pareto-hatékony fogyasztáshoz tartozó kibocsátást. Lehetne azonban pechünk is, előfordulhat, hogy végig kell nézni az összes esetet. Célszerú a III. eset vizsgálatával kezdeni, mivel ez megmutatja nekünk, hogy ha az ottani kibocsátás nem lehet Pareto-hatékony, akkor merre kéne elmozdulnunk. Most azt találtuk, hogy a III. esetet képző $\left(y_{H}, y_{K}\right)=(18,9)$,törésponti” kibocsátása mellett a fogyasztók helyettesítési határaránya -1 lenne. Ugyanakkor $-\frac{1}{2}$ transzformációs rátával előállítható volt több hal kókuszdió helyett, így a kibocsátás nem volt Pareto-hatékony. Ebből az is ,,látszik", hogy a gazdaságban túl kevés hal van, a Pareto-hatékony fogyasztásokhoz tartozó kibocsátás valahol ott lesz, ahol $18<y_{H}, 9>y_{K}$. Ez pedig az I. eset leírása, így a III. eset után elég lenne ezt megvizsgálni. (Ez a trükk csak akkor múködik, ha mindenkinek ugyanolyan homotetikus preferenciája van.)

c. Ekkor:

$$
\left|M_{R}(28,6)\right|=2 \cdot \frac{6}{28}=\frac{3}{7} .
$$

Mivel

$$
\frac{1}{2}>\frac{3}{7}>\frac{1}{3},
$$

ez a $\left(H_{R}, K_{R}\right)$ csak akkor lehet Pareto-hatékony fogyasztás része, ha a termelési lehetôségek halmazában a töréspontjában termelnek, mivel a hatékony termelések többi részén a transzformációs ráta abszolút értéke $\frac{1}{3}$ vagy $\frac{1}{2}$ kéne, hogy legyen. A töréspontban Robinson csak kókuszt szed, Péntek pedig csak halászik, mivel ebben van komparatív előnyük. Így $y_{H}=6 \cdot \alpha$ és $y_{K}=9$. Ebből:

$$
\begin{aligned}
& K_{P}=y_{K}-K_{R}, \\
& K_{P}=9-6=3 .
\end{aligned}
$$


A Pareto-hatékonyságból az is következik, hogy:

$$
\begin{aligned}
\left|\operatorname{MRS}_{P}\left(H_{P}, 3\right)\right| & =\left|\operatorname{MRS}_{R}(28,6)\right|, \\
2 \cdot \frac{3}{H_{P}} & =\frac{3}{7}, \\
14 & =H_{P} .
\end{aligned}
$$

Vagyis az aggregált halkibocsátás, amelyet Péntek állít elő hat óra alatt:

$$
\begin{aligned}
y_{H} & =H_{R}+H_{P}, \\
6 \cdot \alpha & =28+14,
\end{aligned}
$$

tehát

$$
\alpha=7 \text {. }
$$

Vissza a feladathoz

\section{6. feladat:}

a. Robinson kibocsátását $\left(y_{H}, y_{K}\right)$-val jelölve, a termelési lehetőségei halmazának a határát az

$$
y_{H}+\frac{1}{2} \cdot y_{K}=6
$$

egyenlet írja le, mivel egy óra alatt szerez egy halat és fél óra alatt egy kókuszdiót. Ekkor transzformációs határrátájának az abszolút értéke:

$$
\left|\operatorname{MRT}\left(y_{H}, y_{K}\right)\right|=2,
$$

vagyis egy halért cserébe két kókuszdióról kell lemondania. Ha $p>2$, vagyis ha egy halért több mint két kókuszdiót kapni a piacon, akkor nyilván csak halat éri meg termelnie. Ahelyett, hogy kókuszt termel, jobban jár, ha az erre fordított időben inkább tovább halászik, és az így szerzett plusz halakat kókuszra cseréli a piacon. Hasonlóképp, ha $p<2$, akkor csak kókuszt éri meg termelnie. Ha $p=2$, akkor mindegy, mit termel, termelésének az értéke mindenképpen 12 kókuszdió értéke, mivel:

$$
\begin{gathered}
\Pi_{R}=2 \cdot y_{H}+y_{K}, \\
\Pi_{R}=2 \cdot\left(6-\frac{1}{2} \cdot y_{K}\right)+y_{K}, \\
\Pi_{R}=12 .
\end{gathered}
$$


Összefoglalva:

$$
\left(y_{H}, y_{K}\right)= \begin{cases}(6,0), & \text { ha } p>2 \\ \lambda \cdot(6,0)+(1-\lambda) \cdot(0,12), & \text { ha } p=2 \\ (0,12), & \text { ha } p<2\end{cases}
$$

ahol $\lambda \in[0,1]$.

b. Jövedelme a termelése értéke, így:

$$
\Pi_{R}=p \cdot y_{H}+y_{K} .
$$

Az előző pontban leírtak alapján:

$$
\Pi_{R}(p)= \begin{cases}6 \cdot p, & \text { ha } p>2 \\ 12, & \text { ha } p=2 \\ 12, & \text { ha } p<2\end{cases}
$$

Ez a függvény folytonos, úgyhogy a $p=2$ ágat igazából bármelyik másik ághoz hozzácsaphattuk volna, nem kell külön kezelni.

c. Robinson hasznosságfüggvénye egy-egy arányú tökéletes kiegészítő típusú, vagyis optimumban:

$$
H_{R}=K_{R}
$$

Ebből és a

$$
\Pi_{R}(p)=p \cdot H_{R}+K_{R}
$$

költségvetési korlátból:

$$
\begin{aligned}
\Pi_{R}(p) & =p \cdot H_{R}+K_{R} \\
\Pi_{R}(p) & =p \cdot H_{R}+H_{R} \\
\frac{\Pi_{R}(p)}{p+1} & =H_{R},
\end{aligned}
$$

vagyis:

$$
H_{R}(p)=\left\{\begin{array}{cl}
\frac{6 \cdot p}{p+1}, & \text { ha } p \geq 2 \\
\frac{12}{p+1}, & \text { ha } p<2
\end{array}\right.
$$

Vissza a feladathoz 


\section{7. feladat:}

a. $\quad \mathrm{A}\left(q_{x}^{A}, q_{y}^{A}\right)=(4,2)$ kibocsátás belső ponti. Ekkor a profitmaximum feltétel szerint:

$$
p=\left|M R T_{A}(4,2)\right| \text {. }
$$

A könnyebb deriválhatóság kedvéért átírva az $A$ termelési lehetőségeinek határát megadó egyenletet

$$
2 \cdot\left(q_{x}^{A}\right)^{2}+\left(q_{y}^{A}\right)^{2}=36
$$

alakba, azt kapjuk, hogy a transzformációs határráta:

$$
\left|\operatorname{MRT}_{A}\left(q_{x}^{A}, q_{y}^{A}\right)\right|=2 \cdot \frac{q_{x}^{A}}{q_{y}^{A}},
$$

így:

$$
\begin{gathered}
p=\left|M R T_{A}(4,2)\right|, \\
p=2 \cdot \frac{4}{2}, \\
p=4 .
\end{gathered}
$$

b. A $B$ termelési lehetőségeinek határát megadó egyenlet alternatív alakja:

$$
2 \cdot\left(q_{x}^{A}\right)^{2}+\left(q_{y}^{A}\right)^{2}=9
$$

Emellett:

$$
\left|\operatorname{MRT}_{B}\left(q_{x}^{B}, q_{y}^{B}\right)\right|=2 \cdot \frac{q_{x}^{B}}{q_{y}^{B}} .
$$

A profitmaximumban (ha mégsem belső ponti, majd ellentmondást kapunk valahol):

$$
\begin{gathered}
\left|\operatorname{MRT}_{B}\left(q_{x}^{B}, q_{y}^{B}\right)\right|=p, \\
2 \cdot \frac{q_{x}^{B}}{q_{y}^{B}}=4, \\
q_{x}^{B}=2 \cdot q_{y}^{B} .
\end{gathered}
$$


Ezt behelyettesíttve a hatékony termeléseket leíró egyenletbe:

$$
\begin{gathered}
2 \cdot\left(q_{x}^{B}\right)^{2}+\left(q_{y}^{B}\right)^{2}=9, \\
2 \cdot\left(2 \cdot q_{y}^{B}\right)^{2}+\left(q_{y}^{B}\right)^{2}=9, \\
9 \cdot\left(q_{y}^{B}\right)^{2}=9 \\
q_{y}^{B}=1, q_{x}^{B}=2 .
\end{gathered}
$$

Ekkor $B$ fogyasztó y jószágban mért jövedelme termelésének értéke, vagyis:

$$
\begin{aligned}
& m_{B}=p \cdot q_{x}^{B}+q_{y}^{B}, \\
& m_{B}=4 \cdot 2+1=9 .
\end{aligned}
$$

Mivel $B$ hasznosságfüggvénye tökéletes kiegészítő típusú, optimumban:

$$
x_{B}^{*}=y_{B}^{*} .
$$

A költségvetési korlátból:

$$
\begin{gathered}
4 \cdot x_{B}^{*}+1 \cdot y_{B}^{*}=9, \\
4 \cdot x_{B}^{*}+1 \cdot x_{B}^{*}=9, \\
x_{B}^{*}=y_{B}^{*}=\frac{9}{5} .
\end{gathered}
$$

c. Ha $p^{*}=4$ egyensúlyi árarány, akkor a profitmaximalizáló termelések összmennyisége minden piacon megegyezik a fogyasztással, vagyis:

$$
\begin{aligned}
& q_{x}^{A}+q_{x}^{B}=x_{A}+x_{B}, \\
& q_{y}^{A}+q_{y}^{B}=y_{A}+y_{B} .
\end{aligned}
$$


Ezekből:

$$
\begin{aligned}
q_{x}^{A}+q_{x}^{B} & =x_{A}+x_{B}, \\
4+2 & =x_{A}+\frac{9}{5}, \\
\frac{21}{5} & =x_{A},
\end{aligned}
$$

illetve:

$$
\begin{aligned}
q_{y}^{A}+q_{y}^{B} & =y_{A}+y_{B}, \\
2+1 & =y_{A}+\frac{9}{5}, \\
\frac{6}{5} & =y_{A} .
\end{aligned}
$$

Vagyis $A$ fogyasztása belső ponti. Így optimumban teljesül az $M R S$-feltétel, vagyis:

$$
\begin{gathered}
\left|\operatorname{MRS}_{A}\left(x_{A}, y_{A}\right)\right|=p, \\
a=4 .
\end{gathered}
$$

Vissza a feladathoz

\section{8. feladat:}

a. A 6. feladat megoldásában leírtak alapján Robinson csak halat termel, ha $p>1$, csak kókuszt, ha $p<1$, és mindegy neki, hogy a $(2,0)$ és $(0,2)$ kibocsátások milyen konvex kombinációját termeli, ha $p=1$. (Robinson transzformációs rátájának abszolút értéke 1, ezt vetjük össze az árral.)

b. Péntek csak halat termel, ha $p>\frac{1}{2}$, csak kókuszt, ha $p<\frac{1}{2}$, és mindegy neki, hogy a $(12,0)$ és $(0,6)$ kibocsátások milyen konvex kombinációját termeli, ha $p=\frac{1}{2}$. (Péntek transzformációs rátájának abszolút értéke $\frac{1}{2}$, ezt vetjük össze az árral.)

c. Egyensúlyban az össztermelés megegyezik az összfogyasztással minden piacon. A kibocsátást már meghatároztuk az ár függvényeként, lássuk most a fogyasztást. Robinson és Péntek a jövedelméből vásárol magának fogyasztást a $p$ árarány melllett. 
Mindketten a saját maguk által megtermelt jószágok fölött rendelkeznek, így jövedelmük termelésük értéke, vagyis:

$$
\Pi_{R}(p)=p \cdot y_{H}^{R}+y_{K}^{R}, \quad \Pi_{P}(p)=p \cdot y_{H}^{P}+y_{K}^{P} .
$$

Az előző pontban leírtak alapján:

$$
\Pi_{R}(p)=\left\{\begin{array}{ll}
2 \cdot p, & \text { ha } p>1 ; \\
2, & \text { ha } p \leq 1 .
\end{array} \quad \Pi_{P}(p)= \begin{cases}12 \cdot p, & \text { ha } p>\frac{1}{2} \\
6, & \text { ha } p \leq \frac{1}{2} .\end{cases}\right.
$$

Mindkettőjük hasznosságfüggvénye szimmetrikus Cobb-Douglas-típusú, vagyis optimumban:

$$
K_{R}=\frac{1}{2} \cdot \frac{\Pi_{R}}{1}, \quad K_{P}=\frac{1}{2} \cdot \frac{\Pi_{P}}{1} .
$$

Ebből:

$$
K_{R}(p)=\left\{\begin{array}{ll}
p, & \text { ha } p>1 ; \\
1, & \text { ha } p \leq 1 .
\end{array} \quad K_{P}(p)= \begin{cases}6 \cdot p, & \text { ha } p>\frac{1}{2} \\
3, & \text { ha } p \leq \frac{1}{2}\end{cases}\right.
$$

Vizsgáljuk meg, mit történik, ha az ár épp a két transzformációs ráta közé esik, vagyis ha

$$
\frac{1}{2}<p<1
$$

Ekkor Robinson 2 kókuszdiót termel, Péntek pedig 12 halat fog. Ilyen ár mellett az összes kókuszfogyasztás:

$$
K_{R}(p)+K_{P}(p)=1+6 \cdot p
$$

Ez a függvény $p$-ben monoton nő, így ha $\frac{1}{2}<p<1$, akkor:

$$
K_{R}(p)+K_{P}(p)>K_{R}\left(\frac{1}{2}\right)+K_{P}\left(\frac{1}{2}\right)=4 .
$$

Vagyis az aggregált kókuszfogyasztás nagyobb, mint 4, az aggregált kókusztermelés viszont csak 2. Túlkereslet van kókuszból. Egyensúlyban a halnak olcsóbbnak kell lennie, így $p^{*}<\frac{1}{2}$ vagy $p^{*}=\frac{1}{2}$.

I. eset

Ha az árarány kisebb mint $\frac{1}{2}$, akkor senki nem termel halat, pedig minden ilyen árarány mellett pozitív mind Robinson, mind Péntek halfogyasztása. Így az egyensúlyi árarány nem lehet ilyen. 
II. eset

Ha $p^{*}=\frac{1}{2}$, akkor Robinson és Péntek együttes kókuszfogyasztása:

$$
K_{R}\left(\frac{1}{2}\right)+K_{P}\left(\frac{1}{2}\right)=4 .
$$

Ilyen árarány mellett Robinson csak kókuszdiót termel, két darabot. A másik két darabot Péntek simán elő tudja állítani, akár hatot is tudna. Így ez tényleg egyensúlyi árarány.

Nem volt kérdés, de az egyensúlyi kibocsátások:

$$
\left(y_{H}^{R}, y_{K}^{R}, y_{H}^{P}, y_{K}^{P}\right)=(0,2,8,2) .
$$

d. Robinson jövedelme a $p^{*}=\frac{1}{2}$ ár mellett két kókuszdió értéke. Mivel hasznosságfüggvénye szimmetrikus Cobb-Douglas-típusú, halfogyasztása ekkor:

$$
\begin{gathered}
H_{R}=\frac{1}{2} \cdot \frac{\Pi_{R}\left(p^{*}\right)}{p^{*}}, \\
H_{R}=\frac{1}{2} \cdot \frac{2}{\frac{1}{2}}, \\
H_{R}=2 .
\end{gathered}
$$

Vissza a feladathoz

\section{9. feladat:}

a. Jelöljük $y_{j}^{i}$-vel az $i$ fogyasztó kibocsátását a $j$ jószágból. Az adott egyensúlyi fogyasztás,

$$
\left(H_{R}, K_{R}, H_{P}, K_{P}\right)=(15,2,9,6)
$$

mellett az összkibocsátás halból:

$$
y_{H}^{R}+y_{H}^{P}=H_{R}+H_{P}=15+9=24,
$$

és az összkibocsátás kókuszból:

$$
y_{K}^{R}+y_{K}^{P}=K_{R}+K_{P}=2+6=8 .
$$

Az egyéni termelésekhez tartozó transzformációs határráták a szöveg alapján:

$$
\left|M_{R} T_{R}\left(y_{H}^{R}, y_{K}^{R}\right)\right|=2<3=\left|M R T_{P}\left(y_{H}^{P}, y_{K}^{P}\right)\right| .
$$

Vagyis Robinsonnak kókuszszedésben, Pénteknek halászatban van komparatív előnye, vagy Robinson csak akkor fog halászni, ha Péntek egyedül nem tudja megtermelni a 
kívánt mennyiséget. De Péntek egyedül éppen $3 \cdot 8=24$ halat tud fogni, és ennyi az összkibocsátás. Vagyis Péntek csak halászik, Robinson pedig egyáltalán nem halászik, mind az $a$ óráját kókuszszedéssel tölti, így az összkibocsátás kókuszból:

$$
y_{K}^{R}+y_{K}^{P}=1 \cdot a+0=a .
$$

De azt is tudjuk, hogy az összkibocsátás éppen fedezi az összekeresletet, vagyis:

$$
y_{K}^{R}+y_{K}^{P}=K_{R}+K_{P}=2+6=8,
$$

így Robinson is $a=8$ órát dolgozik.

b. A transzformációs ráta itt egyik termelőnél sem értelmezett, és mindketten szélsố pontban termelnek, így profitmaximum-feltételekből nem tudjuk megkapni az árarányt. De Robinson hasznosságfüggvényéből könnyen, mivel a szöveg szerint fogyasztása belső ponti, így teljesül az MRS-feltétel, és:

$$
\begin{gathered}
\left|\operatorname{MRS}_{R}(15,2)\right|=p^{*}, \\
\frac{2}{5}=p^{*} .
\end{gathered}
$$

c. Péntek hasznosságfüggvénye Cobb-Douglas-típusú. Vagyis van olyan monoton transzformációja, amely mellett:

$$
U_{P}\left(H_{P}, K_{P}\right)=H_{P}^{\alpha} \cdot K_{P}^{1-\alpha}
$$

valamilyen $0<\alpha<1$ számra. Az eddigiek alapján Péntek épp 24 halat termel, ez a jövedelme, de csak 9 halat fogyaszt. A Cobb-Douglas-tulajdonság alapján éppen a jövedelme $\alpha$ részét kéne halfogyasztásra költenie, vagyis:

$$
\alpha=\frac{9}{24}=\frac{3}{8} \text {. }
$$

Vissza a feladathoz 
A MONOPÓLIUM 
1. feladat: Miután a mostani két vállalat árelfogadó, árképzési szabályuk a

$$
p_{s}=M C(y)
$$

összefüggés. Emiatt egy vállalat inverz kínálati függvénye:

$$
p_{s}=6+2 y \text {, }
$$

ebből a kínálati függvénye:

$$
y=\left\{\begin{array}{l}
\frac{p_{s}-6}{2}, \text { ha } p_{s}>6, \\
0, \quad \text { egyébként. }
\end{array}\right.
$$

Ebből együttes kínálati függvényük:

$$
y=\left\{\begin{array}{l}
p_{s}-6, \text { ha } p>6, \\
0, \quad \text { egyébként, }
\end{array}\right.
$$

együttes inverz kínálati függvényük:

$$
p_{s}=y+6 \text {, ha } y \geqq 0 .
$$

a. Az egyensúlyi pontban a keresleti ár az adó mértékével haladja meg a kínálati árat:

$$
p_{d}=50-2 * y=6+2 y+8=p_{s}+t
$$

amiből most egy vállalat egyensúlyi termelésére adódik, hogy:

$$
y=9 .
$$

A beszedett adótömeg ebből:

$$
T=(2 * 9) * 8=144
$$

garas. A második esetben az önkormányzati monopólium a határbevétel egyenlő határköltség feltételt teljesíti:

$$
\operatorname{MR}\left(y_{m}\right)=50-2 y_{m}=6+2 y_{m}=M C\left(y_{m}\right),
$$

amiből:

$$
y_{m}=11 .
$$

Az ehhez tartozó ár és profit:

$$
\begin{gathered}
p_{m}=39, \\
\pi_{m}=39 * 11-6 * 11-11^{2}=242,
\end{gathered}
$$

tehát az állam a második megoldást választja. 
b. A fogyasztók fogyasztói többlete a két esetben:

$$
F T_{1}=\frac{(50-(50-18))^{2}}{2}>\frac{(50-(50-11))^{2}}{2}=F T_{2},
$$

tehát számukra az adókivetés a kedvezőbb.

Vissza a feladathoz

2. feladat: Egy profitmaximalizáló, árelfogadó cég árképzési szabálya az

$$
M C(y)=p
$$

egyenlőség. Ebből egy cég termelése a következő módon számítható:

$$
M C(y)=4 y+6=p \Longrightarrow y=\frac{p-6}{4} .
$$

Mivel a piacon négy cég dolgozik, ezért az iparági kínálati függvény:

$$
Y=4 y=p-6
$$

Az iparági egyensúlyi ár a

$$
D(p)=27-0.5 p=p-6=S(p)
$$

összefüggésből számítható:

$$
p=22 \text {. }
$$

Ebből egy cég termelése, illetve profitja:

$$
y=4, \quad \pi=88-(32+24+12)=20 .
$$

A monopólium az

$$
M R(y)=M C(y)
$$

árképzési szabályt alkalmazza, ebből:

$$
54-4 y=4 y+6 \Longrightarrow y=6 .
$$

A monopólium által szabott ár és a monopólium profitja:

$$
p=42, \quad \pi=252-(72+36+12)=132 .
$$

A monopólium maximum annyit hajlandó fizetni, amennyivel ez az összeg meghaladja a versenyzői cégként szerzett profitját:

$$
\Delta \pi=132-20=112 .
$$

Vissza a feladathoz 


\section{3. feladat:}

a. Ha y szerint szeretnénk maximalizálni a profitfüggvényt, akkor az árat is ki kell fejezni ennek függvényeként, azaz meg kell határozni az inverz keresleti függvényt. Mivel a monopólium látja el az egész piacot, ezért:

$$
y=D(p)=20-p .
$$

Ezt átrendezve úgy, hogy az ár a bal oldalon szerepeljen, megkapjuk az árat a monopólium kibocsátásanak a függvényeként (ez az inverz keresleti függvény):

$$
p(y)=20-y .
$$

A monopólium y szerinti profitfüggvénye:

$$
\Pi(y)=p(y) \cdot y-C(y)=(20-y) \cdot y-2 \cdot y-5=(18-y) \cdot y-5 .
$$

Szélsőérték-keresés:

$$
\begin{gathered}
\frac{\mathrm{d} \Pi(y)}{\mathrm{d} y}=18-2 \cdot y^{*}=0, \\
y^{*}=9 .
\end{gathered}
$$

b. A profit:

$$
\Pi(9)=p(9) \cdot 9-C(9)=(18-9) \cdot 9-5=76 .
$$

c. A fix költség az optimális termelést nem befolyásolja, az marad 9. De a profit lecsökken 68-ra.

Vissza a feladathoz 


\section{4. feladat:}

a. Ha $p$ szerint szeretnénk maximalizálni a profitfüggvényt, akkor arra kell figyelni, hogy $p$ ár mellett $D(p)$ mennyiséget fognak vásárolni a fogyasztók, így:

$$
\begin{gathered}
\Pi(p)=p \cdot y(p)-C(D(p)), \\
\Pi(p)=p \cdot(20-p)-2 \cdot(20-p)-5, \\
\Pi(p)=(p-2) \cdot(20-p)-5, \\
\frac{\mathrm{d} \Pi(y)}{\mathrm{d} y}=0 \\
20-2 \cdot p^{*}+2=0 \\
p^{*}=11 .
\end{gathered}
$$

Mivel az ár és a mennyiség között kölcsönösen egyértelmú kapcsolat van, ezért a profitmaximalizáló ár ugyanaz, mint a profitmaximalizáló kibocsátáshoz $\left(y^{*}=9\right)$ tartozó ár.

b. A kereslet árrugalmasságának a definíciója:

$$
\varepsilon_{D}(p)=\frac{\mathrm{d} D(p)}{\mathrm{d} p} \cdot \frac{p}{y(p)} .
$$

A mostani keresleti függvény mellett ez

$$
\begin{aligned}
\varepsilon_{D}(p) & =-\frac{p}{D(p)}, \\
\varepsilon_{D}(11) & =-\frac{11}{9} .
\end{aligned}
$$

c. A fix költség az optimális termelést nem befolyásolja. Így a profit akkor lesz maximális, amikor a monopólium bevétele (a fogyasztók kiadása) maximális. Ez pedig, mint tanultuk, $\varepsilon(p)=-1$-nél van.

Vissza a feladathoz 


\section{5. feladat:}

a. Az inverz keresleti függvény:

$$
\begin{gathered}
y=D(p), \\
y=a-\frac{p}{2}, \\
p(y)=2 \cdot a-2 \cdot y .
\end{gathered}
$$

A monopólium y szerinti nyereségfüggvénye:

$$
\begin{gathered}
\Pi(y)=p(y) \cdot y-C(y)=(2 \cdot a-2 \cdot y) \cdot y-y^{2}, \\
\frac{\mathrm{d} \Pi(y)}{\mathrm{d} y}=2 \cdot a-4 \cdot y^{*}-2 \cdot y^{*}=0, \\
y^{*}=\frac{2 \cdot a}{6}=6,
\end{gathered}
$$

így:

$$
a=18, \quad p^{*}=2 \cdot 18-2 \cdot 6=24 .
$$

b. A holtteherveszteség a versenyzői termelés mellett keletkező többletek és a mostani termelés mellett keletkező többletek különbsége. Versenyzői (árelfogadó) termelés esetén:

$$
\begin{gathered}
p\left(y_{v}\right)=\operatorname{MC}\left(y_{v}\right), \\
36-2 \cdot y_{v}=2 \cdot y_{v}, \\
y_{v}=9, p_{v}=36-2 \cdot 9=18 .
\end{gathered}
$$

Fogyasztói többlet a versenyzői piacon:

$$
N F T_{v}=\frac{(36-18) \cdot 9}{2}=81 .
$$

Termelői többlet a versenyzői piacon:

$$
T T_{v}=\Pi_{v}+F=18 \cdot 9-9^{2}+0=81 .
$$


Fogyasztói többlet monopólium mellett:

$$
N F T_{m}=\frac{(36-24) \cdot 6}{2}=36 .
$$

Termelői többlet monopólium mellett:

$$
T T_{m}=\Pi_{m}+F=24 \cdot 6-6^{2}+0=108 .
$$

A holtteherveszteség:

$$
N F T_{v}+T T_{v}-N F T_{m}-T T_{m}=81+81-36-108=18 .
$$

A holtteherveszteséget ki lehetett volna számolni a szokásos módon, az inverz keresleti és az inverz kínálati (határköltséggörbe) függvényeken a monopolista és verzenyzôi termelések közé eső területként is. A monopólium ennyivel kevesebbet termel az össztöbbletet maximalizáló árelfogadó vállalatnál, és az elvesző többlet az e jószágmennyiséghez tartozó, inverz kereslet és inverz kínálati függvények közé eső rész területe. Ez a rész most egy háromszög, melynek három csúcsa:

$$
\left(y^{*}, p^{*}\right)=(6,24), \quad\left(y^{*}, M C\left(y^{*}\right)\right)=(6,12), \quad\left(y_{v}, p_{v}\right)=(9,18) .
$$

A háromszög területe:

$$
T_{\Delta}=\frac{(24-12) \cdot(9-6)}{2}=18 .
$$

Ez a holtteherveszteség mértéke. (És tényleg ugyanannyi, mint amennyit a másik módszerrel is kaptunk.)

C. A $t$ mennyiségi támogatás mellett a monopólium profitja:

$$
\begin{gathered}
\Pi(y)=(p(y)+t) \cdot y-C(y)=(36-2 \cdot y+t) \cdot y-y^{2}, \\
\frac{\mathrm{d} \Pi(y)}{\mathrm{d} y}=36+t-6 \cdot y^{*}=0, \\
y^{*}=6+\frac{t}{6} .
\end{gathered}
$$

Ezt szeretnénk egyenlővé tenni a versenyzői termeléssel, így:

$$
\begin{gathered}
y^{*}=6+\frac{t}{6}=y_{v}=9, \\
\frac{t}{6}=3, \\
t=18 .
\end{gathered}
$$


Az összes kifizetett támogatás:

$$
t \cdot y_{v}=18 \cdot 9=162 \text {. }
$$

Vissza a feladathoz

\section{6. feladat:}

a. Az inverz keresleti függvény:

$$
\begin{aligned}
& y=40-2 \cdot p \\
& p(y)=20-\frac{y}{2} .
\end{aligned}
$$

A profit:

$$
\begin{gathered}
\Pi=p(y) \cdot y-C(y), \\
\Pi=\left(20-\frac{y}{2}\right) \cdot y-y^{2}-a \cdot y-24, \\
\Pi=\left(20-a-\frac{3 \cdot y}{2}\right) \cdot y-24 .
\end{gathered}
$$

Ez y szerint maximalizálva:

$$
\begin{gathered}
\frac{\mathrm{d} \Pi(y)}{\mathrm{d} y}=0, \\
20-a-3 \cdot y^{*}=0, \\
\frac{20-a}{3}=y^{*} .
\end{gathered}
$$


A feladat szövege szerint a monopólium a fedezeti pontjában termel, vagyis a profit nulla. Így:

$$
\begin{gathered}
\Pi=\left(20-a-\frac{3 \cdot y^{*}}{2}\right) \cdot y^{*}-24, \\
0=\frac{20-a}{2} \cdot \frac{20-a}{3}-24, \\
144=(20-a)^{2} \\
12=20-a, \\
a=8 .
\end{gathered}
$$

b. Az inverz keresleti függvény:

$$
\begin{aligned}
y & =10-2 \cdot p \\
p(y) & =5-\frac{y}{2} .
\end{aligned}
$$

Így a profit most:

$$
\begin{gathered}
\Pi=\left(5-\frac{y}{2}\right) \cdot y-y^{2}-8 \cdot y-24, \\
\Pi=\left(-3-\frac{3 \cdot y}{2}\right) \cdot y-24 .
\end{gathered}
$$

Ez y szerint maximalizálva:

$$
\begin{gathered}
\frac{\mathrm{d} \Pi(y)}{\mathrm{d} y}=0, \\
-3-3 \cdot y^{*}=0, \\
-1=y^{*} .
\end{gathered}
$$

Ez nem lehet, a negatív termelés értelmetlen. Sajnos, kénytelenek vagyunk gondolkodni. A profit $y$ szerinti deriváltja $-3-3 \cdot y$. Ez minden nemnegatív $y$ mellett negatív. 
Vagyis annál nagyobb a profit, minél kisebb $y$. De persze $y$ nem mehet nulla alá, így $y^{*}=0$. Máshogy megfogalmazva, bármilyen $y \geq 0$ mennyiségre

$$
\operatorname{MR}(y)<M C(y),
$$

szóval a határköltség nagyobb, mint a határbevétel, megéri csökkenteni a kibocsátást, amíg csak lehet, ezért optimumban nem fog termelni a monopólium.

Vissza a feladathoz 
MONOPOLISTA VISELKEDÉS 
1. feladat: Szerencsénk van, mert a két csoport keresleti függvényének függőleges tengelymetszete egyaránt 20, ezért az együttes keresleti függvény lineáris, ,nem törik be”. (Ebből már tudhatjuk, hogy a két csoport ugyanakkora árat fog fizetni, ha azokat optimálisan állapítjuk meg.).

a. A két csoport együttes keresleti függvénye:

$$
Q=(30+10))-(1.5+0.5) p=40-2 p .
$$

Ebből az együttes inverz keresleti függvény:

$$
p=20-0.5 Q \text {. }
$$

Az együttes határbevételi függvény:

$$
\operatorname{MR}(Q)=20-Q
$$

Ezt kell egyenlővé tenni a határköltségfüggvénnyel:

$$
20-Q=(Q-2)^{2}+2.25 \text {. }
$$

Megoldásul a

$$
Q=5.5
$$

egyenlőséget kapjuk, azaz ennyiszer ezer néző lesz a meccsen.

b. Ebből kapjuk, hogy:

$$
\operatorname{MR}(5.5)=14.5,
$$

amiből könnyű visszaszámolni a jegyárakat az egyes piacokon. Az önsanyargatók piacának határbevételi függvénye:

$$
\operatorname{MR}\left(q_{\ddot{o}}\right)=14.5=20-\frac{4}{3} q_{\ddot{o}}
$$

amiből:

$$
q_{\ddot{o}}=4.125 \quad \text { és } \quad p_{\ddot{o}}=20-\frac{2}{3} q_{\ddot{o}}=17.25 \text {. }
$$

c. Hasonlóképpen eljárva a rokonok piacán:

$$
\operatorname{MR}\left(q_{r}\right)=14.5=20-4 q_{r},
$$

amiből:

$$
q_{r}=1.375 \quad \text { és } \quad p_{r}=20-2 * q_{r}=17.25 \text {. }
$$

Vissza a feladathoz 
2. feladat: Miután a galambdúctermelés határköltsége konstans, ezért elegendő a két piaci szegmensen külön-külön számolni, mert az

$$
M R_{p}\left(y_{p}\right)=M R_{v}\left(y_{v}\right)=M C\left(y_{p}+y_{v}\right)
$$

elsőrendű feltételek egyszerúsödnek:

$$
M R_{p}\left(y_{p}\right)=M R_{v}\left(y_{v}\right)=M C(y)=5 .
$$

A postagalambdúc piacán:

$$
M R_{p}\left(y_{p}\right)=137-4 y_{p}=5 \Longrightarrow y_{p}=33,
$$

a vadgalambdúc piacán:

$$
M R_{v}\left(y_{v}\right)=275-2 a y_{v}=5 \Longrightarrow y_{v}=\frac{270}{2 a} .
$$

Tudjuk, hogy:

$$
y_{p}=y_{v}+6,
$$

amiből:

$$
27=\frac{270}{2 a} \Longrightarrow a=5
$$

Vissza a feladathoz

3. feladat: Ha a rendelet érvényben van, akkor egy adott árhoz rendelt keresett mennyiség a két vevőkör által keresett mennyiségek összege:

$$
D_{p+t}(p)=(100-2 p)+(75-1.5 p)=175-3.5 p .
$$

a. Ebből az inverz keresleti függvény:

$$
p=50-\frac{1}{3.5} Y .
$$

A határbevétel egyenlő határköltség optimumfeltétel:

$$
M R(Y)=50-\frac{2}{3.5} Y=6=M C(Y)
$$

amiből:

$$
Y=77 \text {. }
$$

b. Ezekből a profit:

$$
\pi=\left(50-\frac{1}{3.5} * 77\right) 77-6 * 77=1694 .
$$


c. A két inverz keresleti és határbevételi függvény:

$$
\begin{aligned}
& p_{p}=50-\frac{1}{2} y_{p}, \quad M R\left(y_{p}\right)=50-y_{p}, \\
& p_{t}=50-\frac{1}{1.5} y_{t}, \quad M R\left(y_{t}\right)=50-\frac{2}{1.5} y_{t} .
\end{aligned}
$$

Miután a határköltség konstans, ezért elég, ha a két piacon külön-külön tesszük egyenlővé a határbevétellel:

$$
\begin{aligned}
& \operatorname{MR}\left(y_{p}\right)=50-y_{p}=6=\operatorname{MC}\left(y_{p}\right), \Rightarrow y_{p}=44, \Rightarrow p_{p}=28 \\
& \operatorname{MR}\left(y_{t}\right)=50-\frac{2}{1.5} y_{p}=6=\operatorname{MC}\left(y_{t}\right), \Rightarrow y_{t}=33, \Rightarrow p_{p}=28
\end{aligned}
$$

azaz nincs mód árdiszkriminációra, és így a monopolista pénzt egyáltalán nem áldoz a rendelet eltörlésére.

Vegyük észre, hogy a két vevőkör inverz keresleti függvényének (függőleges) tengelymetszete ugyanakkora, és emiatt nincs lehetőség árdiszkriminációra. Ekkor azonnal adódik a következtetés, hogy a monopolista pénzt egyáltalán nem áldoz a rendelet eltörlésére. Ha valaki ennyit ír, az is tökéletes megoldás.

Vissza a feladathoz

4. feladat: Ha valaki egyből leírja, hogy lineáris inverz keresleti függvények esetében, egyenlő tengelymetszet mellett nincs lehetőség (értelmes) árdiszkriminációra, mert minden árhoz tartozó árrugalmasság ugyanannyi a két piaci szegmensen, az is tökéletes megoldás.

Először számítsuk ki a profitot az egységes árazás mellett! Ehhez meg kell adnunk az együttes keresleti függvényt:

$$
D(p)=D_{s z}(p)+D_{a}(p)=(40-2 p)+(20-p)=60-3 p .
$$

A maximalizálási feladat ezek után:

$$
\max _{p}\{p(60-3 p)-15(60-3 p)\},
$$

amelynek megoldását megkapjuk, ha deriváljuk a függvényt, és a deriváltat egyenlővé tesszük zérussal:

$$
(60-3 p)-3 p+45=0,
$$

amiből:

$$
\begin{aligned}
& p^{*}=\frac{35}{2}, \\
& q^{*}=7.5 .
\end{aligned}
$$


Ezekből a profit:

$$
\Pi^{*}=\frac{35}{2} * \frac{15}{2}-15 * \frac{15}{2}=\frac{75}{4}=18.75
$$

Ha árdiszkriminálunk, akkor - miután a határköltség konstans - vagy külön-külön megoldjuk a profitmaximalizálási feladatot mind a két szegmensen, vagy a piaci szegmensek inverz keresleti görbéiből számítjuk a határbevételi görbéket, és ezeket tesszük egyenlővé a határköltséggel. Mi itt illusztrációképpen az egyik szegmensen az elsô, a másikon a másik utat követjük.

$$
\max _{p}\{p(40-2 p)-15(40-2 p)\}
$$

az elsőrendû feltétel:

$$
40-4 p+30=0
$$

amiből:

$$
\begin{aligned}
p & =\frac{35}{2}, \\
q_{s z} & =5
\end{aligned}
$$

Az első szegmens profitja:

$$
\Pi_{s z}^{*}=\frac{35}{2} * 5-15 * 5=\frac{25}{2} .
$$

A második szegmensen az inverz keresleti függvény:

$$
p=20-q_{a} .
$$

Ebből a határbevételi függvény:

$$
\operatorname{MR}(q)=20-2 q_{a},
$$

és az optimalitási feltétel:

$$
\operatorname{MR}(q)=20-2 q_{a}=15=\operatorname{MC}(q) .
$$

Ebből:

$$
\begin{aligned}
q_{a} & =\frac{5}{2}, \\
p & =\frac{35}{2} .
\end{aligned}
$$

Az aprítók profitja:

$$
\Pi_{a}^{*}=\frac{35}{2} * \frac{5}{2}-15 * \frac{5}{2}=\frac{25}{4} .
$$


Ezek után az együttes profit:

$$
\Pi^{*}=\Pi_{s z}^{*}+\Pi_{a}^{*}=\frac{25}{2}+\frac{25}{4}=\frac{75}{4},
$$

ami ugyannnyi, mint az egységes árazásnál, ezért egy fityinget sem hajlandó fizetni a szakértőnek.

Vissza a feladathoz

5. feladat: Az inverz keresleti függvények:

$$
\begin{gathered}
y_{1}=D_{1}\left(p_{1}\right)=44-2 \cdot p_{1} \quad \Rightarrow \quad p_{1}\left(y_{1}\right)=22-\frac{1}{2} \cdot y_{1}, \\
y_{2}=D_{2}\left(p_{2}\right)=24-p_{2} \quad \Rightarrow \quad p_{2}\left(y_{2}\right)=24-y_{2} .
\end{gathered}
$$

A monopólium profitja:

$$
\Pi\left(y_{1}, y_{2}\right)=p_{1}\left(y_{1}\right) \cdot y_{1}+p_{2}\left(y_{2}\right) \cdot y_{2}-\left(y_{1}+y_{2}\right)^{2}-4 \cdot\left(y_{1}+y_{2}\right)-7 .
$$

Ezt maximalizálja $y_{1}, y_{2}$ szerint, így az optimum elsőrendú feltételei:

$$
\begin{gathered}
\frac{\mathrm{d} \Pi\left(y_{1}, y_{2}\right)}{\mathrm{d} y_{1}}=0, \\
22-y_{1}-2 \cdot y_{1}-2 \cdot y_{2}-4=0, \\
18-3 \cdot y_{1}-2 \cdot y_{2}=0, \\
\frac{\mathrm{d} \Pi\left(y_{1}, y_{2}\right)}{\mathrm{d} y_{2}}=0, \\
24-2 \cdot y_{2}-2 \cdot y_{1}-2 \cdot y_{2}-4=0, \\
20-2 \cdot y_{1}-4 \cdot y_{2}=0 .
\end{gathered}
$$

Az optimum elsốrendû feltételeit persze úgy is meg lehetett volna fogalmazni, hogy:

$$
M R_{1}\left(y_{1}\right)=M R_{2}\left(y_{2}\right)=M C\left(y_{1}+y_{2}\right) .
$$

Feljebb is ezeket kaptuk meg, csak ilyen alakban:

$$
\begin{aligned}
& M R_{1}\left(y_{1}\right)-M C\left(y_{1}+y_{2}\right)=0, \\
& M R_{2}\left(y_{1}\right)-M C\left(y_{1}+y_{2}\right)=0 .
\end{aligned}
$$


Az egyenleteket megoldva (első kétszerese, mínusz a második, így kiesik $y_{2}$ ):

$$
\begin{gathered}
2 \cdot\left(18-3 \cdot y_{1}-2 \cdot y_{2}\right)-\left(20-2 \cdot y_{1}-4 \cdot y_{2}\right)=2 \cdot 0-0=0, \\
16-4 \cdot y_{1}=0, \\
y_{1}=4 .
\end{gathered}
$$

Ezt visszaírva a második egyenletbe:

$$
\begin{gathered}
20-2 \cdot y_{1}-4 \cdot y_{2}=0, \\
20-2 \cdot 4-4 \cdot y_{2}=0, \\
12-4 \cdot y_{2}=0, \\
y_{2}=3 .
\end{gathered}
$$

Így az árak Kaliforniában, illetve New Yorkban:

$$
\begin{gathered}
p_{1}(4)=22-\frac{1}{2} \cdot 4=20 \\
p_{2}(3)=24-3=21 .
\end{gathered}
$$

Vissza a feladathoz

\section{6. feladat:}

a. Az inverz keresleti függvény:

$$
y=D(p)=60-2 \cdot p \Rightarrow p(y)=30-\frac{1}{2} \cdot y .
$$

Az árdiszkrimináció nélküli optimumfeltétel:

$$
\begin{aligned}
& \operatorname{MR}\left(y_{M}\right)=M C\left(y_{M}\right), \\
& 30-y_{M}=2 \cdot y_{M} .
\end{aligned}
$$

Ebből a közönséges monopolista optimális termelése:

$$
y_{M}=10 .
$$


b. Elsőfokú árdiszkrimináció esetén Pareto-hatékony állapotban vagyunk, mivel a monopólium minden többletet be tud gyújteni, így az összes olyan terméket legyártja, amiért legalább annyit kérhet, mint amennyi a gyártási költsége. A jószág egy marginális egységéért a rezervációs árát tudja elkérni, ezt pedig az inverz keresleti függvény határozza meg. Így az optimumfeltétel:

$$
\begin{gathered}
p\left(y^{*}\right)=M C\left(y^{*}\right), \\
30-\frac{1}{2} \cdot y^{*}=2 \cdot y^{*},
\end{gathered}
$$

amiből:

$$
y^{*}=12 .
$$

c. A profit az első esetben:

$$
\begin{gathered}
p(10)=30-\frac{1}{2} \cdot 10=25, \\
\Pi=25 \cdot 10-10^{2}-7=143 .
\end{gathered}
$$

A profit a második esetben (az összes többletet megkapja a monopólium, és mivel az inverz kereslet és a határköltség is lineáris, a többlet egy háromszög területe):

$$
\frac{(p(0)-M C(0)) \cdot y^{*}}{2}-F=\frac{(30-0) \cdot 12}{2}-7=173 .
$$

A profit 30 egységgel nő.

d. Fogyasztói többlet az első esetben:

$$
N F T=\frac{\left(p(0)-p\left(y_{M}\right)\right) \cdot y_{M}}{2}=\frac{(30-25) \cdot 10}{2}=25 .
$$

A második esetben a fogyasztói többlet 0 , mivel a monopólium szerez meg minden többletet. Tehát a fogyasztói többlet 25-tel csökken a diszkrimináció hatásaként.

A feladat megoldását befejeztük, de érdemes megjegyezni, hogy a fogyasztói többlet kevésbé csökken, mint amennyivel a profit nô. Így az össztöbblet nô az árdiszkrimináció hatására. Ez annyira nem meglepő, mert a közönséges monopolistával szemben az elsőfokú árdiszkriminációt alkalmazó monopólium mellett Pareto-hatékony állapot alakul. A két össztöbblet különbsége a közönséges monopolista mellett jelentkező holtteherveszteség.

Vissza a feladathoz 


\section{7. feladat:}

a. Az inverz keresleti függvények:

$$
\begin{aligned}
& y_{t}=D_{t}\left(p_{t}\right)=52-2 \cdot p_{t} \Rightarrow p_{t}\left(y_{t}\right)=26-\frac{1}{2} \cdot y_{t}, \\
& y_{d}=D_{d}\left(p_{d}\right)=24-4 \cdot p_{d} \Rightarrow p_{d}\left(y_{d}\right)=6-\frac{1}{4} \cdot y_{d} .
\end{aligned}
$$

Az optimum elsőrendű feltételei:

$$
\begin{gathered}
M R_{t}\left(y_{t}\right)=M C\left(y_{t}+y_{d}\right), \\
26-y_{t}=0,
\end{gathered}
$$

illetve:

$$
\begin{gathered}
M R_{d}\left(y_{d}\right)=M C\left(y_{t}+y_{d}\right), \\
6-\frac{1}{2} \cdot y_{d}=0 .
\end{gathered}
$$

Ezekből:

$$
y_{t}=26, p_{t}(26)=13 y_{d}=12, p_{d}(12)=3 \text {. }
$$

b. Csak egy ár van, így lényegében összeolvad a két piac eggyé, ahol az aggregált keresleti függvény:

$$
D_{A}(p)=D_{t}(p)+D_{d}(p)= \begin{cases}0, & 26<p \\ 52-2 \cdot p, & 6<p \leq 26 \\ 76-6 \cdot p, & 0<p \leq 6\end{cases}
$$

A profitmaximum feltétele:

$$
\operatorname{MR}\left(y^{*}\right)=\operatorname{MC}\left(y^{*}\right) .
$$

Azt kell megvizsgálni, hogy a keresleti függvény mely szakaszán lesz megoldása. Ha $0<p \leq 6$ :

$$
M R\left(y^{*}\right)=\frac{76}{6}-\frac{2}{6} \cdot y^{*}=0=M C\left(y^{*}\right) \Rightarrow y^{*}=38, p^{*}=\frac{38}{6} .
$$


De ez az ár nagyobb, mint 6, ezért nem a keresleti függvény ezen szakaszát kéne vizsgálni (a diákok kereslete negatív ilyen ár mellett).

Ha $6<p \leq 26$, akkor, ahogy már láttuk az a. pontban is:

$$
\operatorname{MR}\left(y^{*}\right)=26-y^{*}=0=\operatorname{MC}\left(y^{*}\right) \Rightarrow y^{*}=26, p^{*}=13 .
$$

Ez a megfelelő intervallumba is esik. Mivel $M R(y)$ monoton csökken, $M C(y)$ pedig monoton nő, ezért nem kell megvizsgálnunk a többi lehetséges árintervallumot (a $26<$ $p$-t, habár ott amúgy is nyilvánvaló, hogy nincs profitmaximum).

c. Az elsô esetben volt nagyobb a fogyasztói többlet, hisz a teljes árú jegyet vásárlók ott is ilyen ár mellett vásároltak, a diákok pedig olcsóbb áron vehettek jegyet, és vettek is.

d. Az elsố esetben a profit sem lehetett kisebb, mivel a monopóliumnak ott nagyobb szabadsága volt az árak meghatározásában. Azaz ha a diszkrimináló árak mellett a profit kisebb lenne, mint az egyenár mellett, a monopólium egyszerúen önként egyenárat vezethetne be, és ezzel növelni tudná profitját. Mivel a diszkrimináló árak profitmaximalizálóak voltak, ezért ez nem lehet, vagyis a diszkrimináló profit nem lehet kisebb, mint az egyenáras profit.

A jólét a fogyasztói többlet és a profit összege (plusz fix költség). Mivel a diszkrimináló esetben a fogyasztói többlet nagyobb, a profit meg nem kisebb, mint az egyenáras esetben, a jólét is nagyobb lesz.

Vissza a feladathoz

\section{8. feladat:}

a. Mivel a feladat szövege szerint a sörfőzde mindkét piacon ad el sört, az optimum elsőrendû feltételei:

$$
\begin{aligned}
& M R_{F}\left(y_{F}\right)=\operatorname{MC}\left(y_{F}+y_{K}\right), \\
& M R_{K}\left(y_{K}\right)=M C\left(y_{F}+y_{K}\right) .
\end{aligned}
$$


Az $i$ piaci határbevételt átírhatjuk úgy, hogy:

$$
\begin{gathered}
M R_{i}\left(y_{i}\right)=\frac{\mathrm{d}\left(p_{i}\left(y_{i}\right) \cdot y_{i}\right)}{\mathrm{d} y_{i}}, \\
M R_{i}\left(y_{i}\right)=p_{i}\left(y_{i}\right)+\frac{\mathrm{d} p_{i}\left(y_{i}\right)}{\mathrm{d} y_{i}} \cdot y_{i}, \\
M R_{i}\left(y_{i}\right)=p_{i}\left(y_{i}\right) \cdot\left(1+\frac{\mathrm{d} p_{i}\left(y_{i}\right)}{\mathrm{d} y_{i}} \cdot \frac{y_{i}}{p_{i}\left(y_{i}\right)}\right) .
\end{gathered}
$$

Legyen $p_{i}$ az az ár, ami mellett $D_{i}\left(p_{i}\right)=y_{i}$. Ekkor kihasználva, hogy az inverzfüggvény meredeksége az eredeti függvény meredekségének a reciproka, és a derivált a meredekséget mutatja:

$$
\begin{gathered}
M R_{i}\left(y_{i}\right)=p_{i}\left(y_{i}\right) \cdot\left(1+\frac{\mathrm{d} p_{i}\left(y_{i}\right)}{\mathrm{d} y_{i}} \cdot \frac{y_{i}}{p_{i}\left(y_{i}\right)}\right), \\
M R_{i}\left(y_{i}\right)=p_{i}\left(y_{i}\right) \cdot\left(1+\frac{1}{\frac{\mathrm{d} D_{i}\left(p_{i}\right)}{\mathrm{d} p_{i}}} \cdot \frac{D_{i}\left(p_{i}\right)}{p_{i}}\right) .
\end{gathered}
$$

A jobb oldalon most szerepel az $i$ piaci kereslet árrugalmasságának,

$$
\frac{\mathrm{d} D_{i}\left(p_{i}\right)}{\mathrm{d} p_{i}} \cdot \frac{p_{i}}{D_{i}\left(p_{i}\right)} \text {-nek }
$$

a reciproka, így:

$$
M R_{i}\left(y_{i}\right)=p_{i}\left(y_{i}\right) \cdot\left(1+\frac{1}{\varepsilon_{D_{i}}\left(p_{i}\right)}\right) .
$$

A szöveg szerint optimumban a kocsmai kereslet árrugalmassága $-4 / 3$, illetve a sör kocsmai ára 600 forint, így:

$$
\begin{gathered}
M R_{K}\left(y_{K}\right)=M C\left(y_{F}+y_{K}\right), \\
p_{K}\left(y_{K}\right) \cdot\left(1+\frac{1}{\varepsilon_{D_{K}}\left(p_{K}\right)}\right)=M C\left(y_{F}+y_{K}\right), \\
600 \cdot\left(1+\frac{1}{-4 / 3}\right)=M C\left(y_{F}+y_{K}\right), \\
150=M C\left(y_{F}+y_{K}\right) .
\end{gathered}
$$


A másik optimumfeltételből pedig:

$$
\begin{gathered}
M R_{F}\left(y_{F}\right)=M C\left(y_{F}+y_{K}\right), \\
p_{F}\left(y_{F}\right) \cdot\left(1+\frac{1}{\varepsilon_{D_{F}}\left(p_{F}\right)}\right)=150 .
\end{gathered}
$$

Ha ismernénk a fesztiváli sörkereslet árrugalmasságát, erre is tudnánk válaszolni. És szerencsére ismerjük, mert a fesztiváli sörkeresletet egy hatványfüggvény írja le, és azoknak az árrugalmassága állandó, ugyanis:

$$
\begin{gathered}
\varepsilon_{D_{F}}\left(p_{F}\right)=\frac{\mathrm{d} D_{F}\left(p_{F}\right)}{\mathrm{d} p_{F}} \cdot \frac{p_{F}}{D_{F}\left(p_{F}\right)}, \\
\varepsilon_{D_{F}}\left(p_{F}\right)=\beta \cdot \alpha \cdot p_{F}^{\beta-1} \cdot \frac{p_{F}}{\alpha \cdot p_{F}^{\beta}}, \\
\varepsilon_{D_{F}}\left(p_{F}\right)=\beta=-6 / 5 .
\end{gathered}
$$

Így a fesztiváli ár:

$$
\begin{gathered}
p_{F}\left(y_{F}\right) \cdot\left(1+\frac{1}{\varepsilon_{D_{F}}\left(p_{F}\right)}\right)=150, \\
p_{F}\left(y_{F}\right) \cdot\left(1+\frac{1}{-6 / 5}\right)=150, \\
p_{F}\left(y_{F}\right)=900 .
\end{gathered}
$$

Vegyük észre, hogy ahol abszolút értékben nagyobb a kereslet árrugalmassága, ahol érzékenyebbek a fogyasztók az árra, ott az ügyes árdiszkrimináló monopólium kisebb árat határoz meg.

b. Ez ugye szó szerint a határköltség definíciója, és az előbb már kiszámoltuk, hogy az optimális mennyiségek mellett $M C\left(y_{F}+y_{K}\right)=150$.

Vissza a feladathoz 


\section{9. feladat:}

a. Az inverz keresleti függvény alapján:

$$
\begin{gathered}
p(y) \geq 0, \\
80-2 \cdot y \geq 0, \\
40 \geq y,
\end{gathered}
$$

vagyis összesen 40 egységnyi bérletet lehetne eladni. ${ }^{1}$ De ezek közül a 30-as rezervációs ár alatti bérletek a szöveg szerint ingyen járnak a megfelelő fogyasztóknak. Így:

$$
\begin{gathered}
p(y) \leq 30, \\
80-2 \cdot y \leq 30, \\
25 \leq y,
\end{gathered}
$$

csak az elsô 25 egységnyi bérlet lehet nem ingyenes, a maradék 15 egységnyi bérletet ingyen kell átadni. A 25 egységnyi eladható bérlet közül hányat éri meg eladni? Ha összesen $x$ bérletet ad el a vállalat, akkor $x+15$ bérlet mellett kell üzemeltetni az uszodát (15 bérlet ingyenes), így az $x$-edik bérlet határköltsége:

$$
\begin{gathered}
C(x+15)=\frac{(x+15)^{2}}{4}+25, \\
M C(x+15)=\frac{x+15}{2} .
\end{gathered}
$$

Az $x$-edik eladott bérletért az $x$-edik fogyasztó rezervációs árát, $p(x)$-et lehet elkérni, legalábbis amíg $x \leq 25$, hiszen az ezutáni fogyasztók ingyen kapnak bérletet. Így 0

\footnotetext{
${ }^{1}$ Itt lehetne vitatkozni azon, hogy a 40-ik bérlet kell-e a 40-ik fogyasztónak, de a mennyiségeket továbbra is folytonosként kezeljük, így a 39.9999-ik bérletet ingyen még biztosan elfogadja a 39.9999-ik fogyasztó. Ha nem szeretjük az ilyen nem egész számokat, képzeljük úgy, hogy nem 40, hanem 40 ezer fogyasztóról van szó, ezer a feladatban lévô számok mértékegysége. Ebben az esetben kb. mindegy, hogy 39999 vagy 40000 fogyasztónak lehet bérletet eladni.
} 
eladott bérletről indulva egészen addig éri meg növelni az eladott bérletek mennyiségét, amíg:

$$
\begin{gathered}
M C(x+15) \leq p(x), \\
\frac{x+15}{2} \leq 80-2 \cdot x, \\
x+15 \leq 160-4 \cdot x, \\
x \leq 29 .
\end{gathered}
$$

Mivel $29>25$, az uszodának mind a 25 eladható bérletet megéri eladnia.

b. A bevétel:

$$
\begin{gathered}
R(25)=\int_{0}^{25} p(x) \mathrm{d} x \\
R(25)=\int_{0}^{25} 80-2 \cdot x \mathrm{~d} x \\
R(25)=\left[80 \cdot x-x^{2}\right]_{0}^{25}=1375 .
\end{gathered}
$$

A költség:

$$
C(40)=\frac{40^{2}}{4}+25=425
$$

így a profit:

$$
\Pi=R(25)-C(40)=950
$$

c. A szokásos elsőfokú árdiszkriminációval szemben ezen a piacon lesz holtteherveszteség. Ennek oka az, hogy a kötöttség nélküli árdiszkrimináló monopolista pontosan azon embereknek ad el, akiknek a rezervációs ára nagyobb, mint az utolsó, legdrágábban legyártott termék határköltsége. Így a piacon minden kereskedelemből származó többlet létrejön. Itt viszont a monopólium a vállalt szerződés miatt olyan embereknek is kénytelen bérletet adni, akiknek a bérlet igazából kevesebbet ér, mint amennyit a monopólium hajlandó lenne fizetni azért, hogy ne kelljen eladni az utolsó egység bérletet. Ki kellene számolni, hogy mekkora a veszteség. 
Mivel $p(y)$ monoton csökken és $M C(y)$ monoton nő, az y eladott bérlet melletti

$$
\mathrm{J}(y)=\int_{0}^{y} p(x)-M C(x) \mathrm{d} x
$$

össztöbblet ( $J$ mint jólét) akkor lesz maximális, ha:

$$
p(y)=M C(y),
$$

azaz ha:

$$
\begin{gathered}
p(y)=M C(y), \\
80-2 \cdot y=\frac{y}{2}, \\
y=32 .
\end{gathered}
$$

Ekkor a piacon keletkező össztöbblet:

$$
\begin{gathered}
\mathrm{J}(32)=\int_{0}^{32} p(x)-M C(x) \mathrm{d} x, \\
\mathrm{~J}(32)=\int_{0}^{32} 80-2.5 \cdot x \mathrm{~d} x, \\
\mathrm{~J}(32)=\left[80 \cdot x-1.25 \cdot x^{2}\right]_{0}^{32}=1280 .
\end{gathered}
$$

A feladatban leírt helyzetben 40 egységnyi bérlet cserél gazdát. Ekkor az össztöbblet nem maximális, mivel:

$$
p(40)=0<20=M C(40) \text {. }
$$

Az össztöbblet mértéke:

$$
\begin{gathered}
\mathrm{J}(40)=\int_{0}^{40} p(x)-M C(x) \mathrm{d} x, \\
\mathrm{~J}(40)=\int_{0}^{40} 80-2.5 \cdot x \mathrm{~d} x, \\
\mathrm{~J}(40)=\left[80 \cdot x-1.25 \cdot x^{2}\right]_{0}^{40}=1200 .
\end{gathered}
$$

A maximálisan elérhető többletnél ez 80-nal kisebb, ez a holtteherveszteség mértéke. 
d. Továbbra is 15 bérletet kell ingyen biztosítani, ennyi ember rezervációs ára marad 30 alatt. A maradék 60 bérletet lehet pénzért értékesíteni. A korábbi számításokat megismételve:

$$
\begin{gathered}
M C(x+15) \leq p(x), \\
\frac{x+15}{2} \leq 150-2 \cdot x, \\
x+15 \leq 300-4 \cdot x, \\
x \leq 57 .
\end{gathered}
$$

Így nem éri meg az összes bérletet eladni, 57 eladott bérletnél az eladott mennyiség további növelése kisebb bevételnövekedéssel járna, mint amekkora költségnövekedéssel. A profit:

$$
\begin{gathered}
\Pi=R(57)-C(15+57), \\
\Pi=\int_{0}^{57} 150-2 \cdot x \mathrm{~d} x-\frac{72^{2}}{4}-25=3980 .
\end{gathered}
$$

A maximálisan elérhető jólét

$$
\begin{gathered}
150-2 \cdot y=\frac{y}{2}, \\
60=y
\end{gathered}
$$

gazdát cserélő mennyiség mellett keletkezne. Minden ezutáni mennyiség eladása csökkenti az össztöbbletet. A holtteherveszteség:

$$
\begin{gathered}
\operatorname{HTV}(72)=\int_{60}^{72} M C(x)-p(x) \mathrm{d} x, \\
\operatorname{HTV}(72)=\int_{60}^{72} 2.5 \cdot x-150 \mathrm{~d} x, \\
\operatorname{HTV}(72)=\left[1.25 \cdot x^{2}-150 \cdot x\right]_{60}^{72}=180 .
\end{gathered}
$$

Vissza a feladathoz 
TÉNYEZŐPIACOK 
1. feladat: A KELE-Kótya Rt. által gyártott kelendelő iránti inverz keresleti függvény:

$$
p=120-2 y .
$$

Ebből és a termelési függvényből felírható a cég optimumfeladata:

$$
\max _{K, L}\{(120-2 \sqrt{K L}) \sqrt{K L}-r(K) K-(14+2 L) L\}
$$

ahol $r(K)$ a tőke költsége (ez utóbbira nem lesz szükségünk).

Ezt a munka szerint deriválva kapjuk a munkára vonatkozó optimumfeltételt:

$$
\left(-\frac{\sqrt{K}}{\sqrt{L}}\right) \sqrt{K L}+(120-2 \sqrt{K L}) \frac{\sqrt{K}}{2 \sqrt{L}}-14-4 L=0 .
$$

Ha behelyettesítjük az $L=9$ optimális értéket, akkor:

$$
\left(-\frac{\sqrt{K}}{\sqrt{9}}\right) \sqrt{9 K}+(120-2 \sqrt{9 K}) \frac{\sqrt{K}}{2 \sqrt{9}}-14-36=0,
$$

amiből:

$$
K=25 \text {. }
$$

Most már csak a termelési függvénybe kell visszahelyettesítenünk:

$$
y=\sqrt{K L}=\sqrt{25 * 9}=15 .
$$

Hasonló módon jó a megoldás, ha valaki egyből az optimumfeltétel

$$
M R(y) * M P_{L}=\operatorname{MRP}(L)=M F C(L)
$$

képletét használja:

$$
(120-4 \sqrt{K * 9}) \frac{\sqrt{K}}{2 \sqrt{9}}=14+4 * 9,
$$

amiből:

$$
K=25 \text {. }
$$

Vissza a feladathoz 
2. feladat: A legegyszerúbb megoldás, ha felírjuk a monopolista profitfüggvényét. Ehhez alakítsuk át először a keresleti függvényt inverz keresleti függvénnyé:

$$
p=104-2 y \text {. }
$$

Innen a nyereségfüggvény:

$$
\pi=(104-2 y) y-w x,
$$

ahol $x$ a foglalkoztatott munkások száma. Ha a kibocsátás helyébe beírjuk az

$$
y=5 x
$$

termelési függvényt, akkor a monopolista feladata:

$$
\max _{x}\{(104-2 * 5 x) * 5 x-w x\},
$$

amiből az első rendû feltétel:

$$
520-100 x-w=0 .
$$

Innen a profitmaximalizáló input a bér függvényében:

$$
x=\frac{520-w}{100} .
$$

Ebből a profitmaximalizáló output, illetve ár:

$$
y=5 x=\frac{520-w}{20}, \quad p=104-\frac{520-w}{10} .
$$

Miután a határtermék állandó:

$$
M P(x)=5,
$$

ezért a határtermék piaci áron vett értéke:

$$
p M P(x)=520-\frac{520-w}{2},
$$

ami 250 garassal haladja meg a bért:

$$
520-\frac{520-w}{2}=w+250
$$

amiből:

$$
w=20 \text {. }
$$


b.

Az optimális profit ezután:

$$
\pi=\left(104-\frac{520-20}{10}\right) \frac{520-20}{20}-20 * \frac{520-20}{100}=1250 .
$$

Vissza a feladathoz

3. feladat: A vállalat optimumfeladata a felhasznált munka függvényében a következő:

$$
\max _{L}\left\{p Y(L)-w^{-1}(L) L\right\} .
$$

A termelési függvényt, a munkakínálati függvény inverzét és a megadott értékeket visszahelyettesítve:

$$
\max _{L}\left\{10 *\left(120 L-0.1 L^{2}\right)-(200+4 L) L\right\} .
$$

Az elsőrendû feltétel:

$$
10(120-0.2 L)-(200+8 L)=0 .
$$

Ezt megoldva kapjuk, hogy:

$$
L=100,
$$

az $L$ értékét visszahelyettesítve az inverz munkakínálati függvénybe:

$$
w=600 .
$$

Ha valaki rögtön a

$$
\operatorname{VMP}(L)=p * M P(L)=M F C(L)
$$

optimumfeltételből indul ki, akkor is jó a megoldás.

Vissza a feladathoz

4. feladat: A két esetet külön-külön vizsgáljuk. Az elsőben a bér rögzített:

$$
w=13 \text {. }
$$

Ekkor a BT maximumfeladata:

$$
\max _{L \geqq 0}\{(29-\sqrt{16 L}) \sqrt{16 L}-13 L\} .
$$

Az elsôrendû feltétel:

$$
(29-8 \sqrt{L}) \frac{2}{\sqrt{L}}-13=0
$$


amiből:

$$
L=4 \text {, }
$$

és így:

$$
\pi^{1}=(29-8) 8-13 * 4=116 .
$$

(Ha valaki rögtön az

$$
\operatorname{MRP}(L)=w
$$

optimumfeltételt használta, az is tökéletes.)

A második esetben a BT maximumfeladata:

$$
\max _{L \geqq 0}\{(29-\sqrt{16 L}) \sqrt{16 L}-(5+L) L-16\} .
$$

Az elsőrendû feltétel:

$$
(29-8 \sqrt{L}) \frac{2}{\sqrt{L}}-(5+2 L)=0,
$$

amiből:

$$
L=4 \text {, }
$$

és így:

$$
\pi^{2}=(29-8) 8-(5+4) * 4-16=116 .
$$

(Ha valaki rögtön az

$$
\operatorname{MRP}(L)=\operatorname{MFC}(L)
$$

optimumfeltételt használta, az is tökéletes.)

Miután

$$
\pi^{1}=\pi^{2},
$$

ezért a BT számára mindegy, melyik opciót választja.

Vissza a feladathoz

\section{5. feladat:}


a. A csodaszerből termelt mennyiség az input függvényében:

$$
y=f(x)=2 \cdot \sqrt{x} .
$$

A határtermék:

$$
M P(x)=\frac{1}{\sqrt{x}} .
$$

A vállalat bevétele:

$$
R(y)=p(y) \cdot y .
$$

Az inverz keresleti függvény:

$$
\begin{gathered}
y=D(p)=100-p, \\
p(y)=100-y .
\end{gathered}
$$

A határtermék:

$$
\operatorname{MR}(y)=100-2 \cdot y .
$$

A határtermék-bevétel:

$$
\begin{gathered}
M R P(x)=\frac{\mathrm{d} R(f(x))}{\mathrm{d} x}=M R(y) \cdot M P(x)=M R(f(x)) \cdot M P(x), \\
M R P(x)=(100-2 \cdot f(x)) \cdot \frac{1}{\sqrt{x}}=(100-4 \cdot \sqrt{x}) \cdot \frac{1}{\sqrt{x}}, \\
\operatorname{MRP}(x)=\frac{100}{\sqrt{x}}-4 .
\end{gathered}
$$

b. A tényezőkeresleti függvény azt írja le, hogy w tényezőár mellett mennyit vásárol a vállalat a tényezőből. Ha az inputtényező ára $w$, akkor optimumban

$$
\operatorname{MRP}(x)=w,
$$

mivel az egyenlet bal oldala azt mutatja meg, hogy mi az inputtényező hatása a bevételre, a jobb oldal pedig azt, hogy mi az inputtényezó hatása a költségre. Ha a bal oldal 
nagyobb (kisebb) lenne, akkor a profit növelhető lenne nagyobb (kisebb) tényezőfelhasználással. Így belső ponti optimumban ezek megegyeznek. Ebből a tényezókeresleti függvény:

$$
\begin{gathered}
\operatorname{MRP}(x)=w, \\
\frac{100}{\sqrt{x}}-4=w, \\
\frac{100}{\sqrt{x}}=w+4 \\
\frac{100}{w+4}=\sqrt{x}, \\
x(w)=\left(\frac{100}{w+4}\right)^{2} .
\end{gathered}
$$

Vissza a feladathoz

6. feladat: Jelöljük a tényezőkínálat tényezőár-rugalmasságát $\eta$-val. Ekkor:

$$
\begin{gathered}
\eta=\frac{3}{2}, \\
\frac{\mathrm{d} S\left(p_{x}\right)}{\mathrm{d} p_{x}} \cdot \frac{p_{x}}{S\left(p_{x}\right)}=\frac{3}{2}, \\
1 \cdot \frac{p_{x}}{p_{x}-2}=\frac{3}{2},
\end{gathered}
$$

amiből:

$$
\begin{gathered}
2 \cdot p_{x}=3 \cdot p_{x}-6, \\
p_{x}=6 S\left(p_{x}\right)=p_{x}-2=4 .
\end{gathered}
$$

Mivel minden inputot a monopszónia vásárol meg, ezért:

$$
x\left(p_{x}\right)=S\left(p_{x}\right) .
$$


A profit a tényezőár függvényében:

$$
\begin{gathered}
\Pi\left(p_{x}\right)=p \cdot f\left(x\left(p_{x}\right)\right)-p_{x} \cdot x\left(p_{x}\right), \\
\Pi\left(p_{x}\right)=p \cdot \sqrt{p_{x}-2}-p_{x} \cdot\left(p_{x}-2\right) .
\end{gathered}
$$

A vállalat maximalizálja a profitját. Általában ezt a felhasznált tényezőmennyiség szerint teszi, de most a vállalat monopszónia, így egyértelmú megfeleltetés van a tényező mennyisége és ára között. Ezért kezelhetjük úgy, mintha a tényezőárat határozná meg. (Azzal, hogy ennek az árnak megfelelő mennyiséget vásárol.) Ekkor:

$$
\begin{gathered}
\frac{\mathrm{d} \Pi\left(p_{x}\right)}{\mathrm{d} p_{x}}=0, \\
p \cdot \frac{1}{2 \cdot \sqrt{p_{x}-2}}-2 \cdot p_{x}+2=0 .
\end{gathered}
$$

Tudjuk, hogy optimumban $p_{x}=6$, ezért:

$$
\begin{gathered}
p \cdot \frac{1}{2 \cdot \sqrt{p_{x}-2}}-2 \cdot p_{x}+2=0, \\
p \cdot \frac{1}{2 \cdot \sqrt{4}}-2 \cdot 6+2=\frac{p}{4}-10=0, \\
p=40 .
\end{gathered}
$$

Vissza a feladathoz

\section{7. feladat:}

a. A monopszónia profitja a felhasznált munkaerő függvényében:

$$
\Pi(L)=p \cdot f(L)-w(L) \cdot L .
$$

A feladat szövegéból $p=4$ és $f(L)=100 \cdot L$. Mivel a monopszónia az egyetlen foglalkoztató, a felhasznált munkaerő egyenlő a teljes kínálattal, azaz:

$$
L(w)=S(w)=\frac{w}{100} \Rightarrow w(L)=100 \cdot L .
$$

Az inverz tényezőkínálati függvény:

$$
w(L)=100 \cdot L .
$$


Ezt behelyettesítve a profitfüggvénybe:

$$
\begin{gathered}
\Pi(L)=p \cdot f(L)-w(L) \cdot L, \\
\Pi(L)=4 \cdot 100 \cdot L-100 \cdot L \cdot L, \\
\frac{\mathrm{d} \Pi(L)}{\mathrm{d} L}=400-200 \cdot L^{*}=0, \\
L^{*}=2 .
\end{gathered}
$$

Ugyanez, ha úgy fogjuk fel, hogy ha a monopszónia nem a munkaerő mennyiségét, hanem a munkabért határozza meg:

$$
\begin{gathered}
\Pi(w)=p \cdot f(L(w))-w \cdot L(w)=4 \cdot 100 \cdot \frac{w}{100}-w \cdot \frac{w}{100}, \\
\frac{\mathrm{d} \Pi(w)}{\mathrm{d} w}=4-\frac{2 \cdot w^{*}}{100}=0 \\
w^{*}=200 \\
L(200)=\frac{200}{100}=2 .
\end{gathered}
$$

Ugyanez függvényjelölésekkel:

Akkor optimális a felhasznált munkaerô mértéke, ha:

$$
p \cdot M P\left(L^{*}\right)=\operatorname{MFC}\left(L^{*}\right) .
$$

Határozzuk meg először ezeket a függvényeket, aztán megoldjuk az egyenletet:

$$
\begin{gathered}
f(L)=100 \cdot L, \\
M P(L)=100, \\
p \cdot M P(L)=400,
\end{gathered}
$$




$$
\begin{gathered}
\operatorname{MFC}(L)=\frac{\mathrm{d}(w(L) \cdot L)}{\mathrm{d} L}, \\
\operatorname{MFC}(L)=\frac{\mathrm{d}\left(100 \cdot L^{2}\right)}{\mathrm{d} L}, \\
\operatorname{MFC}(L)=200 \cdot L .
\end{gathered}
$$

Így:

$$
\begin{gathered}
p \cdot M P\left(L^{*}\right)=\operatorname{MFC}\left(L^{*}\right), \\
400==200 \cdot L^{*}, \\
L^{*}=2 .
\end{gathered}
$$

b. Ha kétegységnyi munkaerôt foglalkoztat a gazdaság, akkor a munkabér:

$$
w(2)=100 \cdot 2=200 .
$$

Vissza a feladathoz

8. feladat: Jelöljük a kenyeret $y$-nal. Az inverz keresleti függvény:

$$
y=D(p)=\frac{9}{2}-\frac{1}{24} \cdot p \Rightarrow p(y)=108-24 \cdot y .
$$

Ez alapján a kenyér határbevétele:

$$
\operatorname{MR}(y)=108-48 \cdot y .
$$

Ugyanakkor a termelési függvény alapján:

$$
y=\sqrt{L},
$$

így a határbevétel $L$ függvényében:

$$
\operatorname{MR}(y(L))=108-48 \cdot y=108-48 \cdot \sqrt{L} .
$$

Az inverz tényezőkínálati görbe:

$$
L(w)=w^{2} \Rightarrow w(L)=\sqrt{L} .
$$


Ez alapján:

$$
\begin{gathered}
\operatorname{MFC}(L)=\frac{\mathrm{d}(w(L) \cdot L)}{\mathrm{d} L}, \\
\operatorname{MFC}(L)=\frac{3}{2} \cdot \sqrt{L} .
\end{gathered}
$$

Optimumban:

$$
\begin{gathered}
M P(L) \cdot M R(y(L))=M F C(L), \\
\frac{1}{2 \cdot \sqrt{L}} \cdot(108-48 \cdot \sqrt{L})=\frac{3}{2} \cdot \sqrt{L} \\
L+16 \sqrt{L}-36=0 \\
\sqrt{L}=\frac{-16 \pm \sqrt{256+144}}{2}=2 \\
L=4 \\
w(4)=\sqrt{4}=2 .
\end{gathered}
$$

Vissza a feladathoz 
OLIGOPÓLIUM 


\section{1. feladat:}

a. A követő célfüggvénye:

$$
\max _{y_{2} \geqq 0}\left\{\left(16-\hat{y}_{1}-y_{2}\right) y_{2}-2 y_{2}\right\} .
$$

A

$$
16-\hat{y}_{1}-2 y_{2}-2=0
$$

elsôrendű feltételből kapjuk a reakciófüggvényt:

$$
y_{2}\left(\hat{y}_{1}\right)=7-\frac{\hat{y}_{1}}{2} .
$$

Ezt behelyettesítjük a vezérlő célfüggvényébe:

$$
\max _{y_{1} \geqq 0}\left\{\left(16-y_{1}-\left(7-\frac{y_{1}}{2}\right)\right) y_{1}-y_{1}^{2}\right\} .
$$

Az elsőrendû́ feltétel:

$$
16-2 y_{1}-7+y_{1}-2 y_{1}=0,
$$

amiből:

$$
y_{1}=3 \text {, }
$$

és ebből:

$$
y_{2}=5.5 \text {. }
$$

b. A kartell célfüggvénye:

$$
\max _{y_{1}, y_{2} \geqq 0}\left\{\left(16-\left(y_{1}+y_{2}\right)\right)\left(y_{1}+y_{2}\right)-y_{1}^{2}-2 y_{2}\right\} .
$$

Az optimum elsőrendű feltételei:

$$
\begin{aligned}
16-2 y_{1}-2 y_{2}-2 y_{1} & =0 \\
16-2 y_{1}-2 y_{2}-2 & =0 .
\end{aligned}
$$

Ezekből kapjuk a kartellmegoldást:

$$
y_{1, \text { kartell }}=1 \quad \text { és } \quad y_{2, \text { kartell }}=6 .
$$

A vezérlő termelése tehát

$$
\Delta y_{1}=y_{1, k a r t e l l}-y_{1}=-2
$$

egységgel változik.

Vissza a feladathoz 
2. feladat: Hófehérke akkor kapja meg a pénzt, ha a Csipke Bt. profitja az új helyzetben meghaladja a kartellbeli profitját.

a. A kartell feladata:

$$
\max _{y_{C}, y_{R} \geqq 0}\left\{\left(90-\left(y_{C}+y_{R}\right)\right)\left(y_{C}+y_{R}\right)-10\left(y_{C}+y_{R}\right)\right\} .
$$

Ennek megoldása:

$$
\begin{aligned}
\left(y_{C}+y_{R}\right) & =\frac{90-10}{2 * 1}=40, \\
p & =50 \\
\frac{\pi}{2} & =800 .
\end{aligned}
$$

b. A Csipke Bt. feladata:

$$
\max _{y_{C} \geqq 0}\left\{\left(90-\left(y_{C}+\bar{y}_{R}\right)\right) y_{C}-5 y_{C}-70\right\},
$$

reakciófüggvénye:

$$
y_{C}=\frac{90-5}{2}-\frac{1}{2} \bar{y}_{R} .
$$

A Rózsika Kft. feladata:

$$
\max _{y_{R} \geqq 0}\left\{\left(90-\left(\bar{y}_{C}+y_{R}\right)\right) y_{R}-10 y_{R}\right\},
$$

reakciófüggvénye:

$$
y_{R}=\frac{90-10}{2}-\frac{1}{2} \bar{y}_{C} .
$$

Ezeket megoldva kapjuk, hogy egyensúlyban:

$$
\begin{gathered}
y_{C}^{*}=30, \\
y_{R}^{*}=25, \quad p=35 \\
\pi_{C}=830 .
\end{gathered}
$$

c. Miután kartell esetén a Csipke Bt. profitja alacsonyabb, mint a másik esetben, ezért Hófehérke magkapja a 70 aranytallért.

Vissza a feladathoz 
3. feladat: A Fürge Szarvas Bt. célfüggvénye:

$$
\max _{y_{2} \geqq 0}\left\{\left(20-\hat{y}_{1}-y_{2}\right) y_{2}-a y_{2}\right\} .
$$

A

$$
20-\hat{y}_{1}-2 y_{2}-a=0
$$

elsôrendű feltételből kapjuk a reakciófüggvényt:

$$
y_{2}\left(\hat{y}_{1}\right)=\frac{20-a}{2}-\frac{\hat{y}_{1}}{2} .
$$

Ezt behelyettesítjük az Öreg Bölény Kft. célfüggvényébe:

$$
\max _{y_{1} \geqq 0}\left\{\left(20-y_{1}-\left(\frac{20-a}{2}-\frac{y_{1}}{2}\right)\right) y_{1}-y_{1}^{2}\right\} .
$$

Az elsố rendû feltétel:

$$
20-2 y_{1}-\frac{20-a}{2}+y_{1}-2 y_{1}=0,
$$

amiből:

$$
y_{1}=\frac{10}{3}+\frac{1}{6} a .
$$

Ha az Öreg Bölény Kft. termelése 4, akkor

$$
a=4 \text {. }
$$

és ebből a Fürge Szarvas Bt.-é:

$$
y_{2}=6
$$

Vissza a feladathoz

\section{4. feladat:}

a. Jelöljük Javaharlal és Mohandas kibocsátásait rendre $y_{J}$-vel és $y_{M}$-mel. Ekkor az összes piacra kerülő jakszőrme mennyisége:

$$
Y=y_{J}+y_{M} .
$$

Az emellett kialakuló ár:

$$
p(Y)=50-Y .
$$


Javaharlal profitja:

$$
\begin{gathered}
\Pi_{J}\left(y_{J}, y_{M}\right)=p(Y) \cdot y_{J}-C_{J}\left(y_{J}\right), \\
\Pi_{J}\left(y_{J}, y_{M}\right)=\left(50-y_{J}-y_{M}\right) \cdot y_{J}, \\
\Pi_{J}\left(y_{J}, y_{M}\right)=\left(50-y_{J}-y_{M}\right) \cdot y_{J}-8 \cdot y_{J}, \\
\Pi_{J}\left(y_{J}, y_{M}\right)=\left(42-y_{J}-y_{M}\right) \cdot y_{J} .
\end{gathered}
$$

Ha Mohandas kibocsátása 10, vagyis $y_{M}=10$, akkor:

$$
\Pi_{J}\left(y_{J}, 10\right)=\left(42-y_{J}-10\right) \cdot y_{J}=\left(32-y_{J}\right) \cdot y_{J} .
$$

Javaharlal ezt maximalizálja saját döntési változója, a kibocsátása szerint. A profitmaximumban:

$$
\begin{gathered}
\frac{\mathrm{d} \Pi_{J}\left(y_{J}, 10\right)}{\mathrm{d} y_{J}}=0, \\
32-2 \cdot y_{J}=0, \\
16=y_{J} .
\end{gathered}
$$

b. Ugyanezt az eljárást ismételjük, csak most $y_{M}=20$. Ekkor:

$$
\Pi_{J}\left(y_{J}, 20\right)=\left(42-y_{J}-20\right) \cdot y_{J}=\left(22-y_{J}\right) \cdot y_{J} .
$$

A profitmaximumban:

$$
\begin{gathered}
\frac{\mathrm{d} \Pi_{J}\left(y_{J}, 10\right)}{\mathrm{d} y_{J}}=0, \\
22-2 \cdot y_{J}=0, \\
11=y_{J} .
\end{gathered}
$$


c. Általánosan $y_{M}$ mellett Javaharlal profitja:

$$
\Pi_{J}\left(y_{J}, y_{M}\right)=\left(42-y_{J}-y_{M}\right) \cdot y_{J} .
$$

Emellett, ha maximalizál, akkor:

$$
\begin{gathered}
\frac{\mathrm{d} \Pi_{J}\left(y_{J}, 10\right)}{\mathrm{d} y_{J}}=0, \\
42-2 \cdot y_{J}-y_{M}=0, \\
21-\frac{y_{M}}{2}=y_{J} .
\end{gathered}
$$

Ez utóbbi összefüggés adja meg Javaharlal reakciófüggvényét, mivel ha tudná, hogy mi $y_{M}$ értéke, ennek megfelelően reagálna, alakítaná saját kibocsátását. Ha (számára) optimális kibocsátását így függvényként fogjuk fel, írhatjuk azt, hogy:

$$
y_{J}\left(y_{M}\right)=21-\frac{y_{M}}{2} .
$$

Ebből a függvényből az a. és a b. kérdés válaszait is megkapjuk:

$$
y_{J}(10)=21-\frac{10}{2}=16, \quad y_{J}(20)=21-\frac{20}{2}=11 .
$$

Vissza a feladathoz

\section{5. feladat:}

a. Legyen $Y=y_{1}+y_{2}$. Az inverz keresleti függvény:

$$
p(Y)=30-\frac{Y}{2}
$$

Az első vállalat profitja:

$$
\begin{gathered}
\Pi_{1}\left(y_{1}, y_{2}\right)=p(Y) \cdot y_{1}-C_{1}\left(y_{1}\right), \\
\Pi_{1}\left(y_{1}, y_{2}\right)=\left(30-\frac{Y}{2}\right) \cdot y_{1}-2 \cdot y_{1}, \\
\Pi_{1}\left(y_{1}, y_{2}\right)=\left(28-\frac{y_{1}+y_{2}}{2}\right) \cdot y_{1} .
\end{gathered}
$$


Ha $y_{2}=20$, akkor:

$$
\Pi_{1}\left(y_{1}, 20\right)=\left(38-\frac{y_{1}+20}{2}\right) \cdot y_{1}=\left(18-\frac{y_{1}}{2}\right) \cdot y_{1} .
$$

Az elsố vállalat az $y_{1}$ kibocsátás meghatározásával maximalizálja profitját, így

$$
\begin{gathered}
\frac{\mathrm{d} \Pi_{1}\left(y_{1}, 20\right)}{\mathrm{d} y_{1}}=0, \\
18-y_{1}=0, \\
18=y_{1} .
\end{gathered}
$$

b. Általános $y_{2}$ mellett az első vállalat profitja:

$$
\Pi_{1}\left(y_{1}, y_{2}\right)=\left(28-\frac{y_{1}+y_{2}}{2}\right) \cdot y_{1} .
$$

Ha ezt maximalizálja, akkor:

$$
\begin{aligned}
& \frac{\mathrm{d} \Pi_{1}\left(y_{1}, y_{2}\right)}{\mathrm{d} y_{1}}=0, \\
& 28-y_{1}-\frac{y_{2}}{2}=0 .
\end{aligned}
$$

Ebből az első vállalat reakciófüggvénye:

$$
y_{1}\left(y_{2}\right)=28-\frac{y_{2}}{2} .
$$

c. A második vállalat, megoldva az a. feladatot, tudja, hogy az elsố vállalat kibocsátása 18 lesz, mivel azt hiszi, hogy ezzel maximalizálja a profitját. Ekkor a második vállalat profitja:

$$
\begin{gathered}
\Pi_{2}\left(20, y_{2}\right)=p(Y) \cdot y_{2}-C_{1}\left(y_{2}\right), \\
\Pi_{2}\left(20, y_{2}\right)=\left(30-\frac{18+y_{2}}{2}\right) \cdot y_{2}-2 \cdot y_{2}, \\
\Pi_{2}\left(20, y_{2}\right)=\left(19-\frac{y_{2}}{2}\right) \cdot y_{2} .
\end{gathered}
$$


A második vállalat saját profitját maximalizálja, saját döntési változója, az y2 szerint, így:

$$
\begin{gathered}
\frac{\mathrm{d} \Pi_{2}\left(20, y_{2}\right)}{\mathrm{d} y_{2}}=0, \\
19-y_{2}=0, \\
19=y_{2} .
\end{gathered}
$$

d. A második vállalat profitja az első vállalat kibocsátásában csökkenô:

$$
\Pi_{2}\left(y_{1}, y_{2}\right)=\left(30-\frac{y_{1}+y_{2}}{2}\right) \cdot y_{2}-2 \cdot y_{2} .
$$

Szóval, ha a második vállalat dönthetne $y_{1}$-ről, akkor minél kisebb értéket választana.

Jelöljük $x$-szel azt a mennyiséget, amit az első vállalat a második vállalat kibocsátásának hisz. Az első vállalat reakciófüggvénye:

$$
y_{1}(x)=28-\frac{x}{2}
$$

Persze ennek a minimuma nulla, negatív kibocsátás nem létezik. De $y_{1}$-t a fenti függvény szerint tényleg nulláig lehet csökkenteni a megfelelő hírek terjesztésével, konkrétan:

$$
\begin{gathered}
y_{1}(x) \leq 0, \\
28-\frac{x}{2} \leq 0, \\
56 \leq x .
\end{gathered}
$$

Vagyis a második vállalat azt szeretné elhitetni az elsô vállalattal, hogy legalább 56 lesz a kibocsátása.

Vissza a feladathoz

6. feladat: Ez egy szekvenciális játék, a döntések egymást követik. Így a második vállalat ismeri az elsố vállalat $y_{1}$ kibocsátását, és ennek a függvényeként fogja meghatározni saját kibocsátását. Vagyis $y_{2}$ függvénye lesz az $y_{1}$ változónak. Ennek a jelentősége az, hogy ekkor nem biztos, hogy

$$
\frac{\mathrm{d} y_{2}}{\mathrm{~d} y_{1}}=0 .
$$


Szimultán döntés esetén, ha az elsô vállalat máshogy döntene, az nem hatna ki a második vállalat döntésére. Szekvenciális döntés esetén viszont hathat rá. Számoljuk ki, adott $y_{1}$ mellett hogy dönt a második vállalat. Legyen $Y=y_{1}+y_{2}$. Az inverz keresleti függvény:

$$
p(Y)=100-Y
$$

A második vállalat profitja:

$$
\begin{gathered}
\Pi_{2}\left(y_{1}, y_{2}\right)=p(Y) \cdot y_{2}-C_{2}\left(y_{2}\right), \\
\Pi_{2}\left(y_{1}, y_{2}\right)=(100-Y) \cdot y_{2}-40 \cdot y_{2}, \\
\Pi_{2}\left(y_{1}, y_{2}\right)=\left(60-y_{1}-y_{2}\right) \cdot y_{2} .
\end{gathered}
$$

A második vállalat optimumfeltétele:

$$
\frac{\mathrm{d} \Pi_{2}\left(y_{1}, y_{2}\right)}{\mathrm{d} y_{2}}=60-y_{1}-2 \cdot y_{2}=0 \text {. }
$$

Így a második vállalat optimális döntése $y_{1}$ függvényében (a reakciófüggvénye):

$$
y_{2}\left(y_{1}\right)=30-\frac{y_{1}}{2} .
$$

Még jó, hogy nem tekintettük $y_{2}$-t $y_{1}$-tôl függetlennek, mert

$$
\frac{\mathrm{d} y_{2}\left(y_{1}\right)}{\mathrm{d} y_{1}}=-\frac{1}{2} \neq 0 \text {. }
$$

Az elsô vállalat ennek tudatában fog maximalizálni. A profitja:

$$
\begin{gathered}
\Pi_{1}\left(y_{1}, y_{2}\left(y_{1}\right)\right)=p(Y) \cdot y_{1}-C_{1}\left(y_{1}\right) . \\
\Pi_{1}\left(y_{1}, y_{2}\left(y_{1}\right)\right)=(100-Y) \cdot y_{1}-40 \cdot y_{1} . \\
\Pi_{1}\left(y_{1}, y_{2}\left(y_{1}\right)\right)=\left(60-y_{1}-y_{2}\left(y_{1}\right)\right) \cdot y_{1} . \\
\Pi_{1}\left(y_{1}, y_{2}\left(y_{1}\right)\right)=\left(60-y_{1}-30+\frac{y_{1}}{2}\right) \cdot y_{1} . \\
\Pi_{1}\left(y_{1}, y_{2}\left(y_{1}\right)\right)=\left(30-\frac{y_{1}}{2}\right) \cdot y_{1} .
\end{gathered}
$$


Az első vállalat optimumfeltétele:

$$
\frac{\mathrm{d} \Pi_{1}\left(y_{1}, y_{2}\left(y_{1}\right)\right)}{\mathrm{d} y_{1}}=30-y_{1}=0,
$$

így a számára optimális termelés:

$$
y_{1}=30 \text {. }
$$

Emellett:

$$
y_{2}(10)=30-\frac{30}{2}=15 .
$$

Így a piacon kialakuló egyensúlyi ár:

$$
p(Y)=100-30-15=55 .
$$

Vissza a feladathoz

\section{7. feladat:}

a. Legyen $Y=y_{1}+y_{2}$. Az inverz keresleti függvény:

$$
p(Y)=100-Y \text {. }
$$

Az első vállalat profitja:

$$
\Pi_{1}\left(y_{1}, y_{2}\right)=p(Y) \cdot y_{1}-C_{1}\left(y_{1}\right)=(100-Y) \cdot y_{1}-40 \cdot y_{1}=\left(60-y_{1}-y_{2}\right) \cdot y_{1} .
$$

Az első vállalat optimumfeltétele:

$$
\frac{\mathrm{d} \Pi_{1}\left(y_{1}, y_{2}\right)}{\mathrm{d} y_{1}}=60-2 \cdot y_{1}-y_{2}=0 \text {. }
$$

Az elsố vállalat reakciófüggvénye:

$$
y_{1}\left(y_{2}\right)=30-\frac{y_{2}}{2} .
$$

b. A második vállalat profitja:

$$
\Pi_{2}\left(y_{1}, y_{2}\right)=p(Y) \cdot y_{2}-C_{2}\left(y_{2}\right)=(100-Y) \cdot y_{2}-40 \cdot y_{2}=\left(60-y_{1}-y_{2}\right) \cdot y_{2} \text {. }
$$

A második vállalat optimumfeltétele:

$$
\frac{\mathrm{d} \Pi_{2}\left(y_{1}, y_{2}\right)}{\mathrm{d} y_{2}}=60-y_{1}-2 \cdot y_{2}=0 \text {. }
$$

A második vállalat reakciófüggvénye:

$$
y_{2}\left(y_{1}\right)=30-\frac{y_{1}}{2} .
$$

Egyébként ezt a szimmetriából is megkaphattuk volna. Mivel a költségfüggvényeik azonosak, és egyszerre lépnek, a vállalatok helyzete azonos, optimumfeltételük ugyanolyan lineáris függvény, csak a kibocsátások alsó indexe van kicserélve benne. Így a reakciófüggvény is ugyanolyan lesz, kicserélt alsó indexekkel. 
c. Egy $\left(y_{1}^{*}, y_{2}^{*}\right)$ kibocsátáspárra igaz, hogy mindegyik vállalat optimálisan döntött a másik adott kibocsátása mellett, ha:

$$
y_{1}\left(y_{2}^{*}\right)=y_{1}^{*} \quad y_{2}\left(y_{1}^{*}\right)=y_{2}^{*} .
$$

Ez az $\left(y_{1}, y_{2}\right)$ koordinátarendszerben azt jelenti, hogy az első és a második vállalat reakciófüggvényei az $\left(y_{1}^{*}, y_{2}^{*}\right)$ pontban metszik egymást.

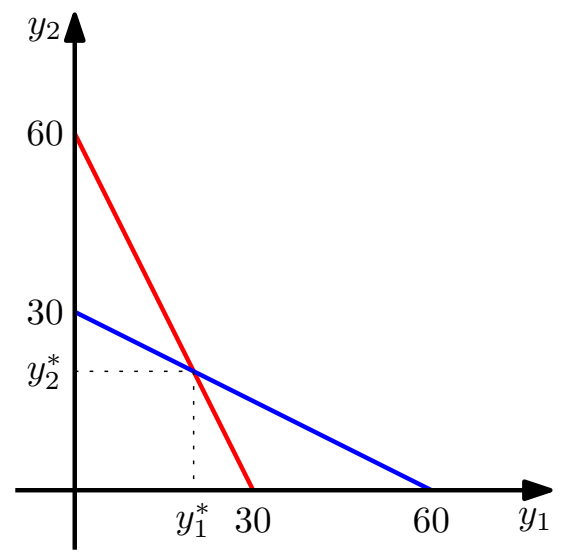

Pirossal ábrázoljuk az elsô, kékkel a második vállalat reakciófüggvényét. Az előbbi függvény igazából nem az $y_{1}$ tengelyről képez $y_{2}$-re, hanem $y_{2}$-ről $y_{1}$-re, de a keresleti függvény-inverz keresleti függvény ábrázolásnál már megszokhattuk, hogy nem számít, melyik a vízszintes tengely.

A metszéspont algebrája:

$$
\begin{gathered}
y_{1}\left(y_{2}^{*}\right)=30-\frac{y_{2}^{*}}{2}, \\
y_{1}^{*}=30-\frac{y_{2}^{*}}{2}, \\
y_{2}\left(y_{1}^{*}\right)=30-\frac{y_{1}^{*}}{2}, \\
y_{2}^{*}=30-\frac{y_{1}^{*}}{2} .
\end{gathered}
$$


Ezeket az egyenleteket felhasználva:

$$
\begin{gathered}
y_{1}^{*}=30-\frac{y_{2}^{*}}{2}, \\
y_{1}^{*}=30-\frac{30-\frac{y_{1}^{*}}{2}}{2}, \\
y_{1}^{*}=15+\frac{y_{1}^{*}}{4}, \\
\frac{3 \cdot y_{1}^{*}}{4}=15, \\
y_{1}^{*}=20,
\end{gathered}
$$

illetve:

$$
y_{2}^{*}=30-\frac{y_{1}^{*}}{2}=30-10=20 .
$$

Egy megjegyzés: az, hogy mindegyik vállalat optimálisan döntött a másik adott kibocsátása mellett, azt jelenti hogy a $(20,20)$ kibocsátáspár egyensúly. A vállalatok szimultán mennyiségi döntést hoztak, vagyis a Cournot-modellben voltunk, így erre a fajta egyensúlyra Cournot-egyensúlyként hivatkozunk.

Vissza a feladathoz

\section{8. feladat:}

a. Bertrand-féle árverseny mellett csak a legkisebb ár számít. Az emellett kialakuló kereslet egyenlően oszlik meg a legkisebb árat kínáló fagyizók között. Ennél magasabb árat kérő fagyizótól senki nem vásárol. Így ha:

$$
p_{2}=300>200=p_{1},
$$

akkor a második fagyizótól senki nem vásárol. Így se bevétele, se költsége nincs, profitja nulla. (Jó, fix költsége lehetne, és akkor a profit a fix költség mínusz egyszerese.) 
b. $\mathrm{Ha}$

$$
p_{2}=100<200=p_{1},
$$

akkor a második fagyizó mondta a legkisebb árat, mindenki tőle vásárol. A kereslet:

$$
D(100)=400-2 \cdot 100=200 .
$$

A bevétel vásárlónként 100 forint, a költség vásárlónként 150 forint. Így a ,nyeresége”:

$$
\begin{gathered}
\Pi_{2}=(p-c) \cdot D(p), \\
\Pi_{2}=(100-150) \cdot 200, \\
\Pi_{2}=-10000 .
\end{gathered}
$$

c. $\mathrm{Ha}$

$$
p_{2}=170<200=p_{1},
$$

akkor a második fagyizó mondta a legkisebb árat, mindenki tőle vásárol. A kereslet:

$$
D(100)=400-2 \cdot 170=60 .
$$

A bevétel vásárlónként 170 forint, a költség vásárlónként 150 forint. Így a nyeresége:

$$
\begin{gathered}
\Pi_{2}=(p-c) \cdot D(p), \\
\Pi_{2}=(170-150) \cdot 60, \\
\Pi_{2}=1200 .
\end{gathered}
$$

d. Legyen az egyensúlyi árpár $\left(p_{1}^{*}, p_{2}^{*}\right)$. Először belátjuk, hogy egyensúlyban

$$
\min \left(p_{1}^{*} ; p_{2}^{*}\right) \geq 150 \text {. }
$$

Ha egyensúlyban valaki 150 forintnál kisebb árat mondott, akkor a legkisebb árat kínáló vállalat veszteséges lesz. De ennél tudna nagyobb profitot elérni. Például ha 150 forintos árat kérne, akkor garantáltan nulla forint hasznot szerezne. Ez ellentmond annak, hogy 150 forintnál kisebb ár mellett lehetséges egyensúly.

Most vizsgáljuk meg, hogy ha a második fagyizó $p_{2}>150$ árat határozott meg, akkor mi az elsô fagyizó számára optimális $p_{1}$ ár! Ha $p_{1}>p_{2}$, akkor az elsô fagyizóba senki nem megy, terméke iránt a kereslete nulla. Ha $p_{1}=p_{2}$, akkor a kereslet megfeleződik, 
az első fagyizóba $\frac{D\left(p_{2}\right)}{2}$ ember megy. Ha $p_{1}<p_{2}$, akkor az összes fagylaltot az első fagyizóban veszik. Vagyis az első fagyizó a

$$
D_{1}\left(p_{1}, p_{2}\right)= \begin{cases}0, & \text { ha } p_{1}>p_{2} ; \\ 200-p_{2}, & \text { ha } p_{1}=p_{2} ; \\ 400-2 \cdot p_{1}, & \text { ha } p_{1}<p_{2}\end{cases}
$$

keresleti függvénnyel szembesül. Ugyanez ábrázolva:

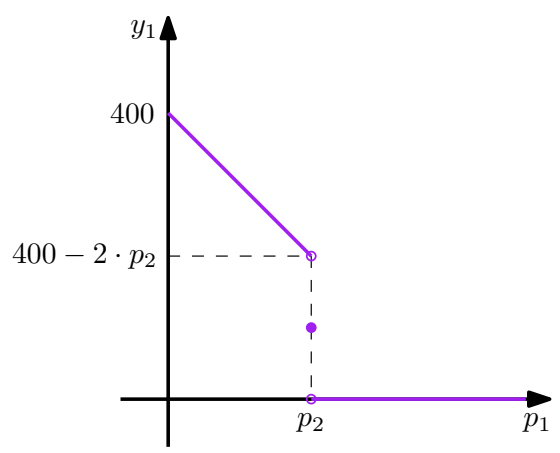

Az első fagyizó profitja:

$$
\Pi_{1}=p_{1} \cdot D_{1}\left(p_{1}, p_{2}\right)-150 \cdot D_{1}\left(p_{1}, p_{2}\right) .
$$

Ha $p_{1}<p_{2}$, akkor:

$$
\Pi_{1}=\left(p_{1}-150\right) \cdot\left(400-2 \cdot p_{1}\right) .
$$

Ennek a függvénynek a maximumhelye $p_{1}=175$. Ha $p_{2}>175$, akkor az elsô vállalat a $p_{1}=175$ ár megválasztásával maximalizálja a profitját. Ez azonban nem lehet egyensúly, mert a második vállalatnak megéri eltérnie. $p_{1}=175$ és $p_{2}>175$ mellett nulla profitot ér el, míg ha $p_{1}=175$ mellett inkább $p_{2}=170$ árat választana, akkor elérhetne 1200 forint profitot. Ha $150<p_{2} \leq 175$, akkor az első fagyizó profitjának nincs maximuma, csak szuprémuma, ugyanis ekkor így alakul $p_{1}$ függvényében: 


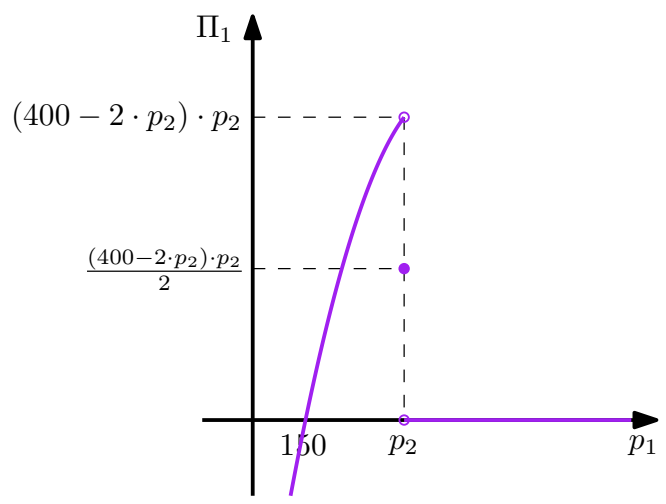

Ilyenkor nincs optimális $p_{1}$ reakció, nincs olyan $\left(p_{1}, p_{2}\right)$ árpár, amelyből ne érné meg az első cukrászdának elmozdulnia. Így $150<p_{2} \leq 175$ mellett sincs egyensúly. Egyensúly csak akkor lehetséges, ha $p_{2}=150$. Ekkor az első fagyizó legfeljebb nulla profitot érhet el. Minden $p_{1} \geq 150$ ár mellett nulla lesz a profitja. Ám ezen árak közül csak a $p_{1}=150$ mellett lehet egyensúly, különben $p_{1}>150$, és ekkor a második fagyizónak megéri elmozdulnia. Ugyanazon okokból, melyeket az első vállalat esetében az imént részletesen tárgyaltunk. Így az egyetlen egyensúly $\left(p_{1}, p_{2}\right)=(150,150)$.

Vissza a feladathoz

9. feladat: Ez szekvenciális játék, így a második vállalat (a magánvállalat) megfigyeli az elsô vállalat által megállapított árat, és ezután dönt saját kibocsátásáról. Így $y_{2}$ függvénye lesz $p$-nek. A feladatot visszagöngyölítéssel oldjuk meg. A második vállalat profitja az ár függvényében:

$$
\Pi_{2}\left(p, y_{2}\right)=p \cdot y_{2}-C_{2}\left(y_{2}\right)=p \cdot y_{2}-y_{2}^{2} .
$$

A magánvállalat optimumfeltétele:

$$
\frac{\mathrm{d} \Pi_{2}\left(p, y_{2}\right)}{\mathrm{d} y_{2}}=p-2 \cdot y_{2}=0 .
$$

Ez alapján a második vállalat kínálati függvénye:

$$
y_{2}(p)=\frac{p}{2} .
$$


A maradék (reziduális) kereslet:

$$
\begin{gathered}
D_{R}(p)=D(p)-y_{2}(p), \\
D_{R}(p)=21-p-\frac{p}{2} \\
D_{R}(p)=21-\frac{3}{2} \cdot p .
\end{gathered}
$$

Az első vállalat a reziduális kereslettel megegyezó mennyiséget termel. Többet nincs értelme, és ha kevesebbet termelne, akkor az ár nem lenne egyensúlyi, lehetne még emelni. Az elsố vállalat profitja:

$$
\begin{gathered}
\Pi_{1}\left(p, y_{2}(p)\right)=p \cdot D_{R}(p)-6 \cdot D_{R}(p) \\
\Pi_{1}\left(p, y_{2}(p)\right)=\left(21-\frac{3}{2} \cdot p\right) \cdot p-6 \cdot\left(21-\frac{3}{2} \cdot p\right) .
\end{gathered}
$$

Az állami vállalat optimumfeltétele:

$$
\begin{aligned}
& \frac{\mathrm{d} \Pi_{1}\left(p, y_{2}(p)\right)}{\mathrm{d} p}=0, \\
& 21-3 \cdot p+9=0,
\end{aligned}
$$

azaz:

$$
p=10 \text {. }
$$

A feladat nem kérdezi, de ebből megkapjuk a termeléseket is:

$$
y_{2}(10)=\frac{10}{2}=5, \quad y_{1}(10)=D_{R}(10)=21-\frac{3}{2} \cdot 10=6 .
$$

Vissza a feladathoz

10. feladat: Legyen $Y=y_{1}+y_{2}$. Az inverz keresleti függvény:

$$
p(Y)=\frac{a-Y}{3} .
$$

Az elsô vállalat profitja:

$$
\begin{gathered}
\Pi_{1}\left(y_{1}, y_{2}\right)=p(Y) \cdot y_{1}-C_{1}\left(y_{1}\right), \\
\Pi_{1}\left(y_{1}, y_{2}\right)=\frac{a-y_{1}-y_{2}}{3} \cdot y_{1}-y_{1}^{2}-25 .
\end{gathered}
$$


Az első vállalat optimumfeltétele:

$$
\begin{gathered}
\frac{\mathrm{d} \Pi_{1}\left(y_{1}, y_{2}\right)}{\mathrm{d} y_{1}}=0, \\
\frac{a-2 \cdot y_{1}-y_{2}}{3}-2 \cdot y_{1}=0 .
\end{gathered}
$$

Innen kétféleképpen lehet befejezni a feladatot. Vagy felhasználjuk a másik vállalat optimumfeltételét, ami:

$$
\frac{\mathrm{d} \Pi_{2}\left(y_{1}, y_{2}\right)}{\mathrm{d} y_{2}}=\frac{a-y_{1}-2 \cdot y_{2}}{3}-2 \cdot y_{2}=0,
$$

ebből megkapjuk a reakciófüggvényeket és megoldjuk a két ismeretlent tartalmazó két egyenletet, vagy azt mondjuk, hogy a szimmetria miatt lesz egy olyan megoldás is, ahol a vállalatok ugyanazt a stratégiát (kibocsátási szintet) határozzák meg. ${ }^{1}$ Így a szimmetriát felhasználva:

$$
\begin{gathered}
\frac{a-2 \cdot y_{1}^{*}-y_{1}^{*}}{3}-2 \cdot y_{1}^{*}=0, \\
y_{1}^{*}=y_{2}^{*}, \\
a-9 \cdot y_{1}^{*}=0, \\
y_{1}^{*}=\frac{a}{9} .
\end{gathered}
$$

Gyors ellenőrzés: $y_{2}=\frac{a}{9}$ mellett az elsô vállalat optimális reakciója:

$$
\begin{gathered}
\frac{a-2 \cdot y_{1}-y_{2}}{3}-2 \cdot y_{1}=0, \\
\frac{a-2 \cdot y_{1}-\frac{a}{9}}{3}-2 \cdot y_{1}=0, \\
\frac{8}{27} \cdot a=\frac{8}{3} \cdot y_{1}, \\
\frac{a}{9}=y_{1},
\end{gathered}
$$

${ }^{1}$ Ezt egyébként elég általános nem lineáris esetekre is bebizonyították, részletek a haladó játékelméletrôl szóló könyvekben (Nash-egyensúly létezése). 
vagyis a szimmetria tényleg múködik (legalábbis az elsô vállalat legjobb válaszában). Ilyen kibocsátások mellett az egyensúlyi profit:

$$
\begin{gathered}
\Pi_{1}\left(y_{1}^{*}, y_{2}^{*}\right)=\frac{a-\frac{a}{9}-\frac{a}{9}}{3} \cdot \frac{a}{9}-\left(\frac{a}{9}\right)^{2}-25, \\
\Pi_{1}\left(y_{1}^{*}, y_{2}^{*}\right)=\frac{7 \cdot a}{27} \cdot \frac{a}{9}-\frac{a^{2}}{81}-25, \\
\Pi_{1}\left(y_{1}^{*}, y_{2}^{*}\right)=\frac{4 \cdot a^{2}}{243}-25 .
\end{gathered}
$$

A szöveg szerint $\Pi_{1}\left(y_{1}^{*}, y_{2}^{*}\right)=275$, így:

$$
\begin{gathered}
\frac{4 \cdot a^{2}}{243}-25=275, \\
a=\sqrt{\frac{243 \cdot(275+25)}{4},} \\
a=135 .
\end{gathered}
$$

Vissza a feladathoz

11. feladat: Legyen $Y=y_{1}+y_{2}$. Az inverz keresleti függvény:

$$
p(Y)=280-Y \text {. }
$$

Az első vállalat profitja:

$$
\Pi_{1}\left(y_{1}, y_{2}\right)=p(Y) \cdot y_{1}-C_{1}\left(y_{1}\right)=\left(280-y_{1}-y_{2}\right) \cdot y_{1}-y_{1}^{2}-20 .
$$

Cournot-duopóliumban, ha az elsô vállalat megváltoztatja kibocsátását, annak nincs hatása a második vállalat kibocsátására. Persze a második vállalat máshogy reagálna, ha előre tudna a változásról, de nem tud róla. Így:

$$
\frac{\mathrm{d} y_{2}}{\mathrm{~d} y_{1}}=0 .
$$

Ez alapján az első vállalat a Cournot-duopóliumbeli optimumfeltétele:

$$
\frac{\mathrm{d} \Pi_{1}\left(y_{1}, y_{2}\right)}{\mathrm{d} y_{1}}=280-2 \cdot y_{1}-y_{2}-2 \cdot y_{1}=280-4 \cdot y_{1}-y_{2}=0 \text {. }
$$


Az azonos költségfüggvény és piaci helyzet miatt a második vállalat Cournotduopóliumbeli optimumfeltétele is ilyen, vagyis:

$$
\frac{\mathrm{d} \Pi_{2}\left(y_{1}, y_{2}\right)}{\mathrm{d} y_{2}}=280-y_{1}-2 \cdot y_{2}-2 \cdot y_{2}=280-y_{1}-4 \cdot y_{2}=0 .
$$

A lineáris egyenletrendszer szimmetrikus, így a megoldásában

$$
y_{1}=y_{2} \text {. }
$$

Ezt kihasználva:

$$
\begin{gathered}
280-4 \cdot y_{1}-y_{2}=0, \\
280-5 \cdot y_{1}=0, \\
280=5 \cdot y_{1}, \\
56=y_{1} .
\end{gathered}
$$

Az első vállalat Cournot-duopolista profitja így:

$$
\Pi_{1}(56,56)=(280-56-56) \cdot 56-56^{2}-20=6252 .
$$

Most számoljuk ki a Stackelberg-duopólium profitját! A második vállalat ekkor megfigyeli az első vállalat kibocsátását és ezután dönt saját kibocsátásáról. Ezért a feladatot visszagöngyölítéssel ${ }^{2}$ oldjuk meg. A második vállalat profitja:

$$
\Pi_{2}\left(y_{1}, y_{2}\right)=p(Y) \cdot y_{2}-C_{2}\left(y_{2}\right)=\left(280-y_{1}-y_{2}\right) \cdot y_{2}-y_{2}^{2}-20 .
$$

A profitmaximum feltétele:

$$
\frac{\mathrm{d} \Pi_{2}\left(y_{1}, y_{2}\right)}{\mathrm{d} y_{2}}=280-y_{1}-2 \cdot y_{2}-2 \cdot y_{2}=280-y_{1}-4 \cdot y_{2}=0 \text {. }
$$

Ez egyébként pont ugyanaz, mint a Cournot-oligopóliumban, mivel a második vállalat döntési változója, $y_{2}$, egyik helyzetben sem befolyásolja az $y_{1}$ változót. A második vállalat reakciófüggvénye (legjobb válasza az első vállalat lépésére):

$$
y_{2}\left(y_{1}\right)=\frac{280-y_{1}}{4} .
$$

\footnotetext{
${ }^{2}$ Először a másodiknak lépó játékos problémáját oldjuk meg az első játékos összes lehetséges lépésére. Ez itt azt jelenti, hogy $y_{1}$-et a második vállalat profitmaximalizációja közben adott paraméterként kezeljük.
} 
Az első vállalat profitja:

$$
\Pi_{1}\left(y_{1}, y_{2}\left(y_{1}\right)\right)=\left(280-y_{1}-y_{2}\left(y_{1}\right)\right) \cdot y_{1}-y_{1}^{2} .
$$

Behelyettesítve a második vállalat reakciófüggvényét:

$$
\begin{gathered}
\Pi_{1}\left(y_{1}, y_{2}\left(y_{1}\right)\right)=\left(280-y_{1}-y_{2}\left(y_{1}\right)\right) \cdot y_{1}-y_{1}^{2}, \\
\Pi_{1}\left(y_{1}, y_{2}\left(y_{1}\right)\right)=\left(280-y_{1}-\frac{280-y_{1}}{4}\right) \cdot y_{1}-y_{1}^{2}, \\
\Pi_{1}\left(y_{1}, y_{2}\left(y_{1}\right)\right)=\frac{3}{4} \cdot\left(280-y_{1}\right) \cdot y_{1}-y_{1}^{2} .
\end{gathered}
$$

Így az első vállalat Stackelberg-duopóliumbeli profitmaximum-feltétele:

$$
\frac{\mathrm{d} \Pi_{1}\left(y_{1}, y_{2}\left(y_{1}\right)\right)}{\mathrm{d} y_{1}}=\frac{3}{4} \cdot\left(280-2 \cdot y_{1}\right)-2 \cdot y_{1}=0
$$

amiből:

$$
y_{1}=60 \text {. }
$$

Ekkor:

$$
y_{2}(60)=\frac{280-60}{4}=55, p(Y)=280-60-55=165,
$$

így az első vállalat profitja:

$$
\Pi_{1}\left(y_{1}, y_{2}\left(y_{1}\right)\right)=165 \cdot 60-60^{2}-20=6280 .
$$

A vállalat legfeljebb annyit adna az elsőnek lépés lehetőségéért, amennyivel megnőtt a profitja, azaz 28-at.

Vissza a feladathoz

\section{2. feladat: Legyen}

$$
Y=\sum_{i=1}^{n} y_{i}
$$

Az inverz keresleti függvény:

$$
p(Y)=a-Y .
$$

Először számoljuk ki az oligopolista profitot Cournot-egyensúlyban! Az elsố vállalat profitja:

$$
\Pi_{1}=p(Y) \cdot y_{1}-c \cdot y_{1}=(a-Y) \cdot y_{1}-c \cdot y_{1}=(a-c-Y) \cdot y_{1}
$$


Az első vállalat optimumfeltétele:

$$
\begin{gathered}
\frac{\mathrm{d} \Pi_{1}}{\mathrm{~d} y_{1}}=0, \\
a-c-2 \cdot y_{1}-\sum_{i=2}^{n} y_{i}=0, \\
a-c-y_{1}-\sum_{i=1}^{n} y_{i}=0, \\
a-c-y_{1}-Y=0 .
\end{gathered}
$$

Mivel a vállalatok helyzete szimmetrikus (ugyanaz a költségfüggvény, és egyszerre lépnek), ha van egyensúly, lesz szimmetrikus egyensúly is, azaz lesz olyan egyensúly, ahol minden $i$-re: $y_{i}^{*}=y_{1}^{*}$, illetve ahol:

$$
Y^{*}=\sum_{i=1}^{n} y_{i}^{*}=n \cdot y_{1}^{*} .
$$

Ezt kihasználva:

$$
\begin{gathered}
a-c-y_{1}^{*}-Y^{*}=0, \\
a-c-(n+1) \cdot y_{1}^{*}=0,
\end{gathered}
$$

azaz

$$
y_{1}^{*}=y_{i}^{*}=\frac{a-c}{n+1} .
$$

Egy vállalat profitja Cournot-egyensúlyban:

$$
\begin{gathered}
\Pi_{i}=(a-c-Y) \cdot y_{i} \\
\Pi_{i}=\left(a-c-\frac{n \cdot(a-c)}{n+1}\right) \cdot \frac{a-c}{n+1}, \\
\Pi_{i}=\left(\frac{a-c}{n+1}\right)^{2} .
\end{gathered}
$$


Ha a vállalatoknak sikerül valahogy megegyezni egy kartell felállításában, akkor a kartell profitja:

$$
\Pi_{K}=\sum_{i=1}^{n}\left(p(Y) \cdot y_{i}-c \cdot y_{i}\right)=p(Y) \cdot Y-c \cdot Y=(a-c-Y) \cdot Y .
$$

A kartell az összes tagvállalat termeléséről dönt, ezért $n$ darab maximumfeltételt kapunk. (Egyet $y_{1}$ szerint, egyet $y_{2}$ szerint, stb.) Ezek most a linearitás miatt megegyeznek, mind a

$$
\frac{\mathrm{d} \Pi_{K}}{\mathrm{~d} y_{i}}=a-c-2 Y=0
$$

alakot öltik. A kartell optimális termelése:

$$
Y_{K}=\frac{a-c}{2}
$$

profitja pedig:

$$
\Pi_{K}=\left(a-c-Y_{K}\right) \cdot Y_{K}=\frac{a-c}{2} \cdot \frac{a-c}{2}=\left(\frac{a-c}{2}\right)^{2} .
$$

A feladat szövege szerint:

$$
\frac{(a-c)^{2}}{(n+1)^{2}}=\Pi_{i}^{*}<\frac{\Pi_{K}}{10}=\frac{(a-c)^{2}}{40}
$$

azaz:

$$
40 \leq(n+1)^{2} .
$$

Ha egész számokban gondolkodunk, ez azt jelenti hogy $6 \leq n$, azaz legalább 6 vállalat van a piacon.

Vissza a feladathoz 
KÜLSŐ GAZDASÁGI HATÁSOK 
1. feladat: $A z$ egységnyi termelés után befizetendő Pigou-adó állandó $-c-$, az összes befizetendő Pigou-adó, tehát a ketyere optimális mennyisége szorozva $c$-vel, azaz

$$
\sum T_{\text {Pigou }}=c * k^{*}
$$

a. Az optmiális mennyiséget úgy kapjuk meg, hogy a két vállalat profitjának összegét maximalizáljuk:

$$
\begin{gathered}
\max _{k, m \geqq 0} \Pi(k, m)=\max _{k, m}\left\{\pi_{k}(k)+\pi_{m}(m, k)\right\}= \\
=\max _{k, m \geqq 0}\left\{110 k-2 k^{2}-10 k+180 m-m^{2}-20 m-c k\right\}
\end{gathered}
$$

Ezeket parciálisan deriváljuk, a parciális deriváltakat egyenlővé tesszük zérussal, ezekből kapjuk az optimális ketyere- és mütyürmennyiséget:

$$
\begin{gathered}
\frac{\partial \Pi(k, m)}{\partial k}=100-c--4 k=0 \\
\frac{\partial \Pi(k, m)}{\partial m}=160-2 m=0,
\end{gathered}
$$

amiből az optimális mütyür- és ketyeremennyiség:

$$
\begin{gathered}
m=80, \\
k^{*}=25-0.25 c .
\end{gathered}
$$

b. Ezekből a befizetendő összes Pigou-adó:

$$
\sum T_{\text {Pigou }}=25 c-0.25 c^{2} .
$$

c. A mütyürtermelés eredeti optimális nagyságát úgy kapjuk, hogy a mütyürtermelő profitját $m$ szerint maximalizáljuk:

$$
\max _{m \geqq 0}\left\{180 m-m^{2}-20 m-c k\right\},
$$

amelynek az optimális megoldása a

$$
\frac{\partial \Pi(k, m)}{\partial m}=160-2 m=0
$$

egyenletből:

$$
m=80,
$$

azaz a mütyürtermelés nagysága nem változik.

Vissza a feladathoz 
2. feladat: A motorcsónakosok a saját hasznukat maximalizálják anélkül, hogy dönthetnének a horgászok által a tavon töltött időről, és azt sem veszik figyelembe, hogy az ő szórakozásuk mennyire zavarja a horgászokat. Ezért az ő feladatuk a következő:

$$
\max _{c \geqq 0}\left\{m_{m}+12 c-c^{2}-2 h\right\} .
$$

Optimumban az elsőrendû feltételből:

$$
\begin{aligned}
12 & =2 c, \\
c & =6 .
\end{aligned}
$$

a. A horgászok ugyanúgy a saját hasznukat maximalizálják azonos feltételek mellett:

$$
\max _{h \geqq 0}\left\{m_{h}+36 h-h^{2}-2 c\right\} \text {. }
$$

Az elsőrendű feltételből:

$$
\begin{gathered}
36=2 h, \\
h=18 .
\end{gathered}
$$

b. Ha az összhasznukat maximalizálják, akkor a következő feladatot oldják meg:

$$
\max _{c, h \geqq 0}\left\{m_{m}+12 c-c^{2}-2 h+m_{h}+36 h-h^{2}-2 c\right\},
$$

a két elsőrendû feltétel:

$$
\begin{gathered}
12-2 c-2=0, \\
-2+36-2 h=0
\end{gathered}
$$

Ezekből:

$$
\begin{gathered}
c=5, \\
h=17,
\end{gathered}
$$

tehát összesen maximum

$$
5+17=22
$$

órát töltenek a tavon.

Vissza a feladathoz 
3. feladat: Elôször azt kell megvizsgálnunk, hány csatát szerveznek a komancsok. Ez a szám független a navajók vadászataitól.

A komancsok profitfüggvénye:

$$
\max _{c s \geqq 0}\left\{100 * c s-c s^{2}\right\}
$$

az elsőrendű feltétel:

$$
100=2 c s
$$

amiből:

$$
c s=50 \text {. }
$$

A komancsok profitja ezek után:

$$
\Pi^{k}=100 * 50-50^{2}=2500 .
$$

a. A navajók feladata:

$$
\max _{v \geqq 0}\left\{100 v-v^{2}-80 c s\right\} .
$$

Az elsőrendû feltétel:

$$
100-2 v=0,
$$

amiből:

$$
v=50 .
$$

Figyelembe véve, hogy a komancsok 50 csatát szerveznek, a navajók (negatív) profitja:

$$
\Pi^{n}=100 * 50-50^{2}-80 * 50=-1500 .
$$

b. A navajók elsô lehetôsége, hogy nem szerveznek vadászatot, ekkor a profitjuk - mint tudjuk - zérus:

$$
\Pi_{1}^{n}=0 .
$$

Ha szerveznek vadászatot, és kifizetik a komancsokat, de csatát nem mutatnak be, akkor maximalizálandó profitjuk:

$$
\max _{v \geqq 0}\left\{100 * v-v^{2}-2500\right\} .
$$

Az elsốrendű feltétel:

$$
100=2 v,
$$

amiből:

$$
v=50 .
$$


Ekkor a navajók profitja:

$$
\Pi_{2}^{n}=100 * 50-50^{2}-2500=0 .
$$

Ha a vadászatok szervezése mellett csatákat is bemutatnak, akkor feladatuk:

$$
\max _{v \geqq 0}\left\{100 * v-v^{2}+100 c s-c s^{2}-80 c s-2500\right\} .
$$

Az elsôrendű feltételek:

$$
\begin{gathered}
100-2 v=0, \\
100-2 c s-80=0 .
\end{gathered}
$$

Ezekből:

$$
\begin{gathered}
v=50, \\
c s=10,
\end{gathered}
$$

valamint:

$$
\Pi_{3}^{n}=100 * 50-50^{2}+100 * 10-10^{2}-80 * 10-2500=100,
$$

azaz a navajók ezt az utolsó lehetőséget választják.

Vissza a feladathoz

\section{4. feladat:}

a. Az erómú profitja:

$$
\Pi(y)=10 \cdot y-y^{2}-6 \cdot y-5 .
$$

A profitmaximum optimumfeltételéből:

$$
\begin{gathered}
p=M C\left(y_{c}\right), \\
10=2 \cdot y_{c}+6, \\
y_{c}=2 .
\end{gathered}
$$


b. A háztartások hőből származó haszna $8 \cdot y$. Így a társadalmi összhaszon:

$$
8 \cdot y+\Pi(y)=8 \cdot y+10 \cdot y-y^{2}-6 \cdot y-5 .
$$

Társadalmi optimumban:

$$
\begin{gathered}
18-2 \cdot y^{*}-6=0, \\
y^{*}=6 .
\end{gathered}
$$

c. Az erőmú $t$ mennyiségi támogatás melletti profitja:

$$
\Pi(y)=(10+t) \cdot y-y^{2}-6 \cdot y-5 .
$$

Az szeretnék elérni a támogatással, hogy 6 legyen az optimális termelés:

$$
\begin{gathered}
p+t=M C(6), \\
10+t=2 \cdot 6+6, \\
t=8 .
\end{gathered}
$$

d. Két megoldást nézünk végig. Elsőnek a hagyományos kereslet-kínálatos megoldást:

Legyen a hőegység ára $q$. Mivel a háztartásoknak 8 petákot ér a hőegység, a keresleti függvény:

$$
D(q)= \begin{cases}10, & q<8 ; \\ {[0,10],} & q=8 ; \\ 0, & q>8 .\end{cases}
$$

A hőegységek kínálati függvényét az erőmú profitjából fogjuk levezetni. A q hőegység ár melletti profit:

$$
\Pi(y)=10 \cdot y-y^{2}-6 \cdot y-5+q \cdot y .
$$

Ezt $y$ szerint optimalizálva:

$$
\begin{aligned}
p+q & =M C\left(y_{q}\right), \\
10+q & =2 \cdot y_{q}+6, \\
y_{q} & =2+\frac{q}{2} .
\end{aligned}
$$


Ez az erőmú kínálati függvénye. Egyensúlyban a hőegységek kereslete megegyezik a kínálattal, vagyis:

$$
D(q)=S(q) .
$$

A keresleti függvény szakaszos, de megvizsgálva az eseteket, egyensúly csak úgy lehetséges, ha $q=8$ és $D(q)=6=S(q)$.

Második megoldás: mivel a hőegységnek most versenyzői piaca van (és a Paretohatékony mennyiség nagyobb, mint az egyéni), a hőegység egyensúlyi mennyisége a társadalmilag optimális mennyiség lesz, azaz 6. E mennyiség mellett a háztartások hasznának hőegység szerinti deriváltja is 8 , ezért ennyit fognak fizetni a hőegységekért. Azt is mondhattuk volna, hogy már láttuk a c. pontban, hogy az erőmú 8 egységnyi áramár-támogatás mellett termelne 6 hőegységet, ennyit kell kapjon a háztartásoktól is.

e. A feladat csak annyiban különbözik a korábbitól, hogy ki kapja meg a jogokért járó jövedelmet. Az egyensúlyi mennyiség továbbra is 6, azaz 4 háztartástól vásárolja vissza a jogokat az erőmú.

Vissza a feladathoz

\section{5. feladat:}

a. Az acélmúvek profitja:

$$
\Pi_{s}(s, x)=24 \cdot s-s^{2}+s \cdot x-x^{2} .
$$

Az optimumfeltételek:

$$
\begin{aligned}
& p_{s}=\frac{\mathrm{d} C_{s}(s, x)}{\mathrm{d} s}, \\
& 24=2 \cdot s_{c}-x_{c}, \\
& 0=\frac{\mathrm{d} C_{s}(s, x)}{\mathrm{d} x}, \\
& 0=2 \cdot x_{c}-s_{c} .
\end{aligned}
$$

Az egyenletrendszert megoldva:

$$
x_{c}=8, \quad s_{c}=16 .
$$

A halászok profitja:

$$
\Pi_{f}(f, x)=16 \cdot f-f^{2}-f \cdot x .
$$


Az optimumfeltétel:

$$
\begin{aligned}
& p_{f}=\frac{\mathrm{d} C_{f}(f, x)}{\mathrm{d} f}, \\
& 16=2 \cdot f_{c}+x_{c} .
\end{aligned}
$$

Egyensúlyban az acélmúvek $x_{c}=4$ szennyezési szintet állít be. Erre a halászat optimális reakciója:

$$
\begin{gathered}
16=2 \cdot f_{c}+8, \\
f_{c}=4 .
\end{gathered}
$$

b. Az összhaszon:

$$
\Pi_{s}(s, x)+\Pi_{f}(f, x)=24 \cdot s-s^{2}+s \cdot x-x^{2}+16 \cdot f-f^{2}-f \cdot x .
$$

Az optimumfeltételek:

$$
\begin{gathered}
p_{s}=\frac{\mathrm{d} C(s, x)}{\mathrm{d} s}, \\
24=2 \cdot s^{*}-x^{*}, \\
p_{f}=\frac{\mathrm{d} C(f, x)}{\mathrm{d} f}, \\
16=2 \cdot f^{*}+x^{*}, \\
0=\frac{\mathrm{d} C(s, x)}{\mathrm{d} x} \\
0=2 \cdot x^{*}+f^{*}-s^{*} .
\end{gathered}
$$


Az egyenletrendszert megoldva:

$$
\begin{gathered}
16=2 \cdot f^{*}+x^{*}, \\
x^{*}=16-2 \cdot f^{*}, \\
0=2 \cdot x^{*}+f^{*}-s^{*}=2 \cdot\left(16-2 \cdot f^{*}\right)+f^{*}-s^{*}=32-3 \cdot f^{*}-s^{*} \\
s^{*}=32-3 \cdot f^{*}, \\
24=2 \cdot s^{*}-x^{*}=2 \cdot\left(32-3 \cdot f^{*}\right)-\left(16-2 \cdot f^{*}\right)=48-4 \cdot f^{*}, \\
f^{*}=6, s^{*}=14, x^{*}=4 .
\end{gathered}
$$

c. Legyen $q$ a szennyezési kvóta egységára. A halászok eldöntik, hogy mennyi kvótát adnak el $\left(x_{f}\right)$, az acélmúvek pedig azt, hogy mennyit vásárolnak $\left(x_{s}\right)$ a $q$ kvótaár mellett. Versenyzői egyensúlyban a halászok pont annyi kvótát adnak el, mint amennyit az acélmúvek megvesz, ezért egyensúlyban $x_{f}^{*}=x_{s}^{*}$. Azt is tudjuk, hogy az egyensúly Pareto-hatékony, azaz társadalmilag optimális. Ez az előző pont alapján azt jelenti, hogy $x_{f}^{*}=x_{s}^{*}=4$. Az acélmúvek profitja:

$$
\Pi_{s}\left(s, x_{s}\right)=24 \cdot s-s^{2}+s \cdot x_{s}-x_{s}^{2}-q \cdot x_{s} .
$$

Az acélmúvek optimumfeltételei:

$$
\begin{aligned}
& p_{s}=\frac{\mathrm{d} C\left(s, x_{s}\right)}{\mathrm{d} s}, \\
& 24=2 \cdot s^{*}-x_{s}^{*}, \\
& -q=\frac{\mathrm{d} C_{s}\left(s, x_{s}\right)}{\mathrm{d} x_{s}}, \\
& -q=2 \cdot x_{s}^{*}-s^{*} .
\end{aligned}
$$

A halászok profitja:

$$
\Pi_{f}\left(f, x_{f}\right)=16 \cdot f-f^{2}-f \cdot x_{f}+q \cdot x_{f} .
$$


A halászok optimumfeltételei:

$$
\begin{gathered}
p_{f}=\frac{\mathrm{d} C\left(f, x_{f}\right)}{\mathrm{d} f}, \\
16=2 \cdot f^{*}-x_{f}^{*}, \\
q=\frac{\mathrm{d} C_{f}\left(f, x_{f}\right)}{\mathrm{d} x_{f}}, \\
q=f^{*} .
\end{gathered}
$$

Ahogy már tárgyaltuk, egyensúlyban $x_{f}^{*}=x_{s}^{*}$. Ezt felhasználva megoldhatjuk ezt az egyenletrendszert. Sôt, igazából nem is kell, mert az

$$
f^{*}=q=-\left(2 \cdot x_{s}^{*}-s^{*}\right)
$$

egyenletekből megkapjuk a korábbi, b. pontbeli

$$
f^{*}+\left(2 \cdot x_{s}^{*}-s^{*}\right)=0
$$

egyenletet, és ezzel visszakaptuk a b. pontbeli egyenletrendszert. Annak a megoldása pedig:

$$
f^{*}=6, s^{*}=14, x^{*}=x_{f}^{*}=x_{s}^{*}=4 .
$$

Visszahelyettesítve megkapjuk a kvóta árát is:

$$
q=f^{*}=6 .
$$

A halászok profitja így:

$$
\Pi_{f}(6,4)=16 \cdot 6-6^{2}-6 \cdot 4+6 \cdot 4=60 .
$$

Vissza a feladathoz

\section{6. feladat:}

a. Addig lépnek be taxik, amíg a hasznuk nulla nem lesz, vagyis:

$$
\begin{gathered}
100-x-10=0, \\
90=x .
\end{gathered}
$$


b. A szakszervezet az összprofitot maximalizálja:

$$
\begin{gathered}
\max _{x \geqq 0}\{x \cdot(100-x)-10 \cdot x\}, \\
100-2 \cdot x^{*}-10=0, \\
x^{*}=45 .
\end{gathered}
$$

c. Ha 45 taxi van, egy taxi haszna $100-45-10=45$. Ennyit ér egy engedély.

d. Érdekes módon nem az. Ennek oka, hogy az összprofit nem maximális. Ha $x=20$, akkor minden taxis 80 dollárt keres, amiből a 10 dolláros költség levonása után 70 dollár a haszon. Tegyük fel, hogy belép még 20 taxis. Ekkor minden taxis haszna 50 dollár. Ha minden új taxist párosítunk egy régi taxissal, és a pár új tagja ad a réginek mondjuk 30 dollárt, akkor a régi taxisok haszna 80, az új taxisok haszna 20 dollár. Ez minden jelenlegi taxisnak jobb, mint a régi $x=20$ melletti helyzet, ahol a régi taxisok haszna 70, az új taxisok haszna 0 dollár volt, így az $x=20$ mellett kialakuló helyzet nem Pareto-hatékony.

Vissza a feladathoz

\section{7. feladat:}

a. Az egyes államok bevétele a mezőgazdasági kibocsátástól, a költségük a felhasznált vízmennyiségektől függ. Az egyes államok elvileg döntenek mind a kibocsátásukról, mind a felhasznált vízmennyiségről. De mivel maximalizálják profitjaikat, ezért nem használnak feleslegesen sok vizet. Egy egységnyi kibocsátáshoz egy km³ víz kell, így profitmaximumban a kibocsátás ugyanakkora, mint a vízfelhasználás. Ezért csak ez utóbbit fogjuk az államok döntési változójának tekinteni. Jelöljük Karnataka vízfelhasználását (és kibocsátását) $x_{K}$-val, Tamil Nadu vízfelhasználását pedit $x_{T}$-vel! Karnatakában a szöveg szerint évi $21 \mathrm{~km}^{3}$ a folyó vízhozama. Így az állam $x_{K}$ egység mezőgazdasági terményt

$$
(25-21) \cdot x_{K}+x_{K}^{2}=4 \cdot x_{K}+x_{K}^{2}
$$

költséggel tud előállítani. Karnataka állam haszna:

$$
\Pi_{K}=28 \cdot x_{K}-4 \cdot x_{K}-x_{K}^{2}
$$


Optimumban:

$$
\begin{gathered}
\frac{\mathrm{d} \Pi_{K}}{\mathrm{~d} x_{K}}=0, \\
28-4-2 \cdot x_{K}=0, \\
12=x_{K} .
\end{gathered}
$$

Tamil Naduban a Kaveri vízhozama már csak évi $21-x_{K} \mathrm{~km}^{3}$. Így az állam $x_{T}$ egység mezőgazdasági terményt

$$
\left(25-21+x_{K}\right) \cdot x_{T}+x_{T}^{2}=\left(4+x_{K}\right) \cdot x_{T}+x_{T}^{2}
$$

költséggel tud előállítani. Tamil Nadu állam haszna:

$$
\Pi_{T}=28 \cdot x_{T}-\left(4+x_{K}\right) \cdot x_{T}-x_{T}^{2} .
$$

Mivel Tamil Nadu csak $x_{T}$-ról dönthet, aszerint maximalizálunk. Optimumban:

$$
\begin{gathered}
\frac{\mathrm{d} \Pi_{T}}{\mathrm{~d} x_{T}}=0, \\
28-4-x_{K}-2 \cdot x_{T}=0 .
\end{gathered}
$$

Ahogy az előbb kiszámoltuk, Karnata profitmaximalázicója után $x_{K}=12$. Így Tamil Nadu optimális vízfelhasználása:

$$
\begin{gathered}
28-4-x_{K}-2 \cdot x_{T}=0 \\
28-4-12-2 \cdot x_{T}=0 \\
6=x_{T} .
\end{gathered}
$$

b. Az államok együttes haszna:

$$
\Pi_{K}+\Pi_{T}=28 \cdot\left(x_{K}+x_{T}\right)-4 \cdot x_{K}-x_{K}^{2}-\left(4+x_{K}\right) \cdot x_{T}-x_{T}^{2} .
$$


Ezt maximalizálva mind $x_{K}$, mind $x_{T}$ szerint $^{1}$

$$
\begin{gathered}
\frac{\mathrm{d}\left(\Pi_{K}+\Pi_{T}\right)}{\mathrm{d} x_{K}}=0, \\
28-4-2 \cdot x_{K}-x_{T}=0, \\
\frac{\mathrm{d}\left(\Pi_{K}+\Pi_{T}\right)}{\mathrm{d} x_{T}}=0, \\
28-4-x_{K}-2 \cdot x_{T}=0 .
\end{gathered}
$$

Ez a lineáris egyenletrendszer szimmetrikus. Az államok helyzete nem szimmetrikus. Itt talán kifejezetten jól látszik, hogy a szimmetriát matematikai, nem közgazdasági fogalomként használjuk. A szimmetria miatt (persze enélkül is kijön, nem muszáj használni) szimmetrikus lesz a megoldás, vagyis $x_{K}=x_{T}$. Ezt felhasználva:

$$
\begin{gathered}
28-4-2 \cdot x_{K}-x_{T}=0, \\
24-2 \cdot x_{K}-x_{K}=0, \\
8=x_{K} .
\end{gathered}
$$

c. Legyen $q$ a vízfelhasználási jog egységára. Karnataka eldönti, hogy adott $q$ egységárért cserébe hány $\mathrm{km}^{3}$ víz felhasználásáról mond le. Jelöljük ezt $v_{K}$-val. Tamil Nadu pedig arról dönt, hogy az adott $q$ ár mellett mennyi lemondásért hajlandó fizetni. Jelöljük ezt $v_{T}$-vel. Versenyzői egyensúlyban $v_{K}^{*}=v_{T}^{*}$. Ez az összefüggés fogja meghatározni a $q^{*}$ versenyzői árát. Karnataka profitmaximum-feladata:

$$
\max _{x_{K}, v_{K} \geqq 0}\left\{28 \cdot x_{K}-4 \cdot x_{K}-x_{K}^{2}+q \cdot v_{K}\right\},
$$

$$
\text { f.t.h. } x_{K}=12-v_{K} \text {. }
$$

A feltétel azt mondja ki, hogy $12 \mathrm{~km}^{3}$ vizet van joga felhasználni. Ennek a jognak egy részét érvényesítheti, más részét eladhatja, de az összmennyiség $12 \mathrm{~km}^{3}$-re szól. Karnataka feltétel nélküli optimumfeladata, amikor a korlátját beépítjük a célfüggvényébe:

$$
\max _{v_{K} \geq 0}\left\{28 \cdot\left(12-v_{K}\right)-4 \cdot\left(12-v_{K}\right)-\left(12-v_{K}\right)^{2}+q \cdot v_{K}\right\} .
$$

\footnotetext{
${ }^{1}$ Nem kell, hogy az államok egyeztessenek. Elég, ha Karnataka figyelembe veszi, hogy döntése költséggel jár Tamil Nadunak, és eszerint optimalizál. Tamil Nadu ezután viselkedhet teljesen önző módon, mivel az ő döntése már nem hat ki Karnatakára.
} 
Ugyanez egy kicsit egyszerübb alakra hozva:

$$
\max _{v_{K}}\left\{24 \cdot 12+(q-24 \cdot) v_{K}-\left(12-v_{K}\right)^{2}\right\}
$$

Optimumban:

$$
\begin{gathered}
q-24-(-1) \cdot 2 \cdot\left(12-v_{K}\right)=0, \\
q-2 \cdot v_{K}=0, \\
\frac{q}{2}=v_{K},
\end{gathered}
$$

vagyis $q$ függvényében ennyi jogot ad el Karnataka. Tamil Nadu optimumfeladata:

$$
\begin{gathered}
\max _{x_{T}, v_{T} \geqq 0}\left\{28 \cdot x_{T}-\left(4+x_{K}\right) \cdot x_{T}-x_{T}^{2}-q \cdot v_{T}\right\}, \\
\text { f.t.h. } x_{K}=12-v_{T} .
\end{gathered}
$$

A feltétel azt mondja ki, hogy Karnataka $12 \mathrm{~km}^{3}$-nél annyival kevesebb vizet fog felhasználni, amennyit megvesz tôle Tamil Nadu. A tamil állam feltétel nélküli optimumfeladata, amikor a korlátját beépítjük a célfüggvényébe:

$$
\max _{x_{T}, v_{T} \geqq 0}\left\{28 \cdot x_{T}-\left(4+12-v_{T}\right) \cdot x_{T}-x_{T}^{2}-q \cdot v_{T}\right\} .
$$

Ugyanez egy kicsit egyszerúbb alakra hozva:

$$
\max _{x_{T}, v_{T} \geqq 0}\left\{\left(12+v_{T}\right) \cdot x_{T}-q \cdot v_{T}-x_{T}^{2}\right\} .
$$

Az optimumfeltételek:

$$
\begin{gathered}
12+v_{T}-2 \cdot x_{T}=0, \\
x_{T}-q=0 .
\end{gathered}
$$

Ezt az egyenletrendszert megoldva:

$$
x_{T}=q, \quad v_{T}=2 \cdot q-12 .
$$

Elsőre furcsának tûnhet, hogy $v_{T}$ növekvő függvénye $q$-nak. Ez azért van, mert $v_{T}$ az $x_{T}$ növekvő függvénye, és csak akkor érheti meg valamennyi, de nem az összes jogot 
megvenni, ha $x_{T}=q$. Ha egyensúlyban van a vízfelhasználási jogok piaca, akkor:

$$
\begin{gathered}
v_{K}=v_{T}, \\
\frac{q}{2}=2 \cdot q-12, \\
8=q .
\end{gathered}
$$

Ebből a fenti levezetések alapján:

$$
x_{T}=q=8, \quad v_{K}=v_{T}=2 \cdot q-12=4, \quad x_{K}=12-v_{K}=8 .
$$

A versenyzői piac valóban a társadalmilag optimális megoldáshoz, Pareto-hatékony állapothoz vezetett.

Sôt, ezt a tulajdonságot felhasználva jóval hamarabb is megkaphattuk volna a társadalmilag optimális megoldást: a társadalmi optimumban $x_{K}=8$. Épp annyit kell fizetni a vízfelhasználási jogért Karnatakának, hogy ne érje meg élnie vele. Karnataka határhaszna a vízfelhasználás megnöveléséből:

$$
\frac{\mathrm{d} \Pi_{K}}{\mathrm{~d} x_{K}}=24-2 \cdot x_{K} .
$$

Ez $x_{K}=8$ mellett 8 . Ha ilyen áron eladhatja a jogot, akkor nem fogja 8 fölé növelni a felhasználását.

Vissza a feladathoz 
KÖZJAVAK 


\section{1. feladat:}

a. Az én haszonmaximalizálási feladatom (a költségvetési korlátot már behelyettesítve):

$$
\max _{q \geqq 0}\left\{20 q^{1 / 2}+42-p q\right\}
$$

Az elsôrendű feltétel:

$$
\frac{20}{2 q^{1 / 2}}-p=0
$$

amiből:

$$
q=\frac{100}{p^{2}} .
$$

Behelyettesítve a 16, számomra optimális termelést:

$$
16=\frac{100}{p^{2}}
$$

kapjuk, hogy:

$$
p=2.5 \text {. }
$$

b. Ha én tehát 16 egység világítást finanszíroznék, akkor ez egy tetszőleges szomszédomnak annyit jelent, hogy a maximumfeladata a következővé alakul:

$$
\max _{q_{s z} \geqq 0}\left\{10 \sqrt{q_{s z}+16}+42-2.5 q_{s z}\right\} .
$$

Az elsőrendű feltétel:

$$
\frac{10}{2 \sqrt{q_{s z}+16}} * 1-2.5=0
$$

Ennek a gyöke negatív, így a nemnegatív közjószág hozzájárulásokon vett maximum helye zérus, azaz mindenki más potyázik. Ebből az összedobott mennyiség:

$$
q^{*}=16 .
$$


c. A közjószág Pareto-hatékony szintje mellett:

$$
\sum M R S=M R T
$$

ami esetünkben a következő módon számítható. Az én helyettesítési határarányom:

$$
\frac{\frac{20}{2 \sqrt{q}}}{1}
$$

a többieké:

$$
\frac{\frac{10}{2 \sqrt{q}}}{1} \text {. }
$$

Ezekből:

$$
\sum M R S=\frac{20}{2 \sqrt{q}}+(N-1) \frac{10}{2 \sqrt{q}}=2.5=M R T
$$

de mivel

$$
q=16+468=484
$$

ezért:

$$
\frac{20}{2 \sqrt{484}}+(N-1) \frac{10}{2 \sqrt{484}}=2.5,
$$

amiből:

$$
N=10
$$

Vissza a feladathoz

2. feladat: Mint tudjuk, optimumban:

$$
\sum|\operatorname{MRS}(v, b)|=|M R T(v, b)| .
$$

a. Egy, a Méregzsák törzsfőnököt támogató harcos esetében a helyettesítési határarány:

$$
\left|\operatorname{MRS}^{t}(v, b)\right|=\frac{M U_{v}^{t}(v, b)}{M U_{b}^{t}(v, b)}=\frac{6-2 v}{1} .
$$

Egy, a Méregzsák törzsfőnököt ellenző harcos esetében a helyettesítési határarány:

$$
\left|M_{R S}^{e}(v, b)\right|=\frac{M U_{v}^{e}(v, b)}{M U_{b}^{e}(v, b)}=\frac{30-4 v}{1} .
$$

A transzformációs határarány:

$$
|M R T(v, b)|=60 .
$$

Ezekből a megoldandó egyenlet:

$$
10 * \frac{6-2 v}{1}+20 * \frac{30-4 v}{1}=60
$$

és a megoldás:

$$
v^{o}=6 .
$$


b. Egy, a Méregzsák törzsfőnököt támogató harcos optimumfeladata:

$$
\begin{gathered}
\max _{v, b \geqq 0}\left\{-(v+\bar{v})^{2}+6(v+\bar{v})+b\right\}, \\
60 v+b \leqq \infty
\end{gathered}
$$

ahol $\bar{v}$ a többi harcos által megvásárolt varázslatok száma.

Az optimumfeltétele:

$$
p=M U_{v}(v, b)
$$

azaz:

$$
-2(v+\bar{v})+6=60,
$$

amiből - lévén $\bar{v}$ szükségképpen nemnegatív -:

$$
v=\frac{54+2 \bar{v}}{-2}<0,
$$

azaz egy támogató harcos sem vesz varázslatot.

Hasonlóképpen: egy, a Méregzsák törzsfőnököt ellenző harcos optimumfeladata:

$$
\begin{gathered}
\max _{v, b \geqq 0}\left\{-2(v+\bar{v})^{2}+30(v+\bar{v})+b\right\}, \\
60 v+b \leqq \infty .
\end{gathered}
$$

Az optimumfeltétele:

$$
-4(v+\bar{v})+30=60,
$$

amiből - lévén $\bar{v}$ szükségképpen nemnegatív -:

$$
v=\frac{30+4 \bar{v}}{-4}<0
$$

azaz egy ellenző harcos sem vesz varázslatot.

Így a megvett varázslatok száma:

$$
v^{*}=0 \text {. }
$$

Vissza a feladathoz 


\section{3. feladat:}

a. Mindenki magának épít mújégpályát, így itt az is magánjószág. Jelöljük az $i$ edik fogyasztó által épített pálya méretét $y_{i}$-vel. Mivel mindenki nagyon gazdag, a fogyasztás belsố pontban lesz, így teljesül az $M R S$-feltétel:

$$
\begin{gathered}
\left|\operatorname{MRS}_{i}\left(x_{i}, y_{i}\right)\right|=\frac{p_{x}}{p_{y}}, \\
\frac{1}{\frac{10}{\sqrt{y_{i}}}}=\frac{1}{2}, \\
\frac{\sqrt{y_{i}}}{10}=\frac{1}{2}, \\
\sqrt{y_{i}}=5, \\
y_{i}=25 .
\end{gathered}
$$

b. A mújégpálya most közjószág, így Pareto-hatékony állapotban a helyettesítési határarányok összege megegyezik a határköltséggel. Természetesen nem mindegy, hogy a helyettesítési határarányok közül melyiket használjuk, azt kell vizsgálni, hogy mennyi pénzt kérnének a közjószág egy egységéért. Az előző pontban nem ezt vizsgáltuk, hanem ennek a reciprokát. (Azaz hogy mennyi közjószágot kérnek egy pénzegységért.)

$$
\begin{gathered}
\sum_{i}\left|\operatorname{MRS}_{i}\left(y, x_{i}\right)\right|=\frac{p_{y}}{p_{x}}, \\
20 \cdot \frac{\frac{10}{\sqrt{y}}}{1}=\frac{2}{1}, \\
100=\sqrt{y} \\
y=10000 .
\end{gathered}
$$

Vissza a feladathoz 


\section{4. feladat:}

a. Mivel $x$ és $y$ mértéke is pénz, $p_{x}=p_{y}=1$, így optimumban:

$$
\begin{gathered}
\left|\operatorname{MRS}_{i}\left(x_{i}, y_{i}\right)\right|=\frac{p_{x}}{p_{y}}, \\
\frac{1}{\frac{1}{y_{i}}}=\frac{1}{1}, \\
y_{i}=1 .
\end{gathered}
$$

Az összkiadás $\sum_{i=1}^{8} y_{i}=8 \cdot 1=8$.

b. Az ételfogyasztás ára most $p_{y}=\frac{1}{8}$, mivel 1 dollárnyi saját fogyasztás után most a fogyasztónak csak egynyolcad dollárt kell kifizetni, a maradékot a többiek fizetik. Így az $i$ fogyasztó számára egyénileg akkor optimális az $x_{i}^{\prime}, y_{i}^{\prime}$ fogyasztás, ha:

$$
\begin{gathered}
\left|\operatorname{MRS}_{i}\left(x_{i}^{\prime}, y_{i}^{\prime}\right)\right|=\frac{p_{x}}{p_{y}}, \\
\frac{1}{\frac{1}{y_{i}^{\prime}}}=\frac{1}{8}, \\
y_{i}^{\prime}=8 .
\end{gathered}
$$

Az összkiadás $\sum_{i=1}^{8} y_{i}^{\prime}=8 \cdot 8=64$.

c. Az összhasznosságot kiszámolhatjuk közvetlenül. Jelölje $m_{i}$ az $i$ fogyasztó vagyonát. Egyéni fizetésnél a költségvetési korlátból:

$$
\forall i: x_{i}=m_{i}-y_{i}
$$

Ahogy korábban láttuk, $y_{i}=1$, így:

$$
\forall i: x_{i}=m_{i}-1 .
$$

Az egyes fogyasztók hasznossága egyéni fizetés esetén:

$$
U_{i}\left(m_{i}-1,1\right)=m_{i}-1+\ln 1 .
$$


Amikor egyenlő részekre osztják a számlát, akkor:

$$
\forall i: x_{i}^{\prime}=m_{i}-\frac{\sum_{i=1}^{8} y_{i}^{\prime}}{8} .
$$

Ahogy korábban láttuk, $\forall i: y_{i}^{\prime}=8$, így:

$$
\forall i: x_{i}^{\prime}=m_{i}-8 \text {. }
$$

Az egyes fogyasztók hasznossága a számla szétosztása esetén:

$$
U_{i}\left(m_{i}-8,8\right)=m_{i}-8+\ln 8 .
$$

A két esetben kapott hasznosságokat összehasonlítva (melyik a nagyobb?):

$$
\begin{gathered}
m_{i}-1+\ln 1 ? m_{i}-8+\ln 8, \\
8-1 ? \ln 8-\ln 1
\end{gathered}
$$

A számológép szerint $8-1>\ln 8-\ln 1$, így:

$$
\begin{gathered}
8-1>\ln 8-\ln 1, \\
m_{i}-1+\ln 1>m_{i}-8+\ln 8, \\
U_{i}\left(m_{i}-1,1\right)>U_{i}\left(m_{i}-8,8\right),
\end{gathered}
$$

vagyis mindenkinek jobb volt, amikor a saját számláját fizette.

Vissza a feladathoz

\section{5. feladat:}

a. A közjószág előállításának marginális költsége 1 , mivel g-t pénzben mértük. (És egy egység pénzt elkölteni egy egység pénzbe kerül.) A társadalmi optimumban:

$$
\begin{gathered}
\sum_{i}\left|\operatorname{MRS}_{i}\left(g^{*}, x_{i}\right)\right|=M C\left(g^{*}\right), \\
100 \cdot \frac{\frac{1}{2 \cdot \sqrt{g^{*}}}}{1}=1, \\
50=\sqrt{g^{*}} \\
g^{*}=2500 .
\end{gathered}
$$


b. Jelöljük $t_{i}$-vel az $i$ által befizetett adót. A szöveg szerint $\sum_{i=1}^{n} t_{i}=g$. Az $i$ fogyasztó költségvetési korlátja $t_{i}+x_{i}=250$. Hogy ossza szét jövedelmét a kettő között, feltéve, hogy a többiek $t_{-i}=\sum_{j \neq i} t_{j}$ adót fizetnek? A helyettesítési határarányt és a költségvetési korlát meredekségét kell összehasonlítani, vagyis az $M R S$-feltétel adja a megoldást:

$$
\begin{gathered}
\left|\operatorname{MRS}_{i}\left(t_{i}+t_{-i}, x_{i}\right)\right|=1, \\
\frac{\frac{1}{2 \cdot \sqrt{t_{i}+t_{-i}}}}{1}=1, \\
\frac{1}{2}=\sqrt{t_{i}+t_{-i}}, \\
\frac{1}{4}=\sum_{i=1}^{n} t_{i} .
\end{gathered}
$$

Mindenki számára ez az optimumfeltétel. Vagyis nem tudni, hogy pontosan kik mennyit fizetnek be, de összesen $\frac{1}{4}$ auno solt fizetnek.

c. A társadalmilag optimális kiadásszinthez fejenként:

$$
t_{i}=\frac{g^{*}}{100}=25
$$

adót kellene fizetni, emellett 225 sol marad magánjószágra. A hasznosság ekkor:

$$
U_{i}(2500,225)=\sqrt{2500}+225=275 .
$$

Ha elcsalom az egész adót, de a többiek sem fizetik rendesen, akkor pedig:

$$
U_{i}\left(\frac{1}{4}, 250\right)=\sqrt{\frac{1}{4}}+250=250.5
$$

Tehát jó, ha betartatják a adótörvényeket.

Vissza a feladathoz 


\section{Mikrökonómiai feladatok tára II.}

Ez a példatár, amely az elmúlt években a Budapesti Corvinus Egyetemen a Mikroökonómia II. címú tárgy oktatása során használt feladatainkból ad válogatást, folytatása a nemrégiben megjelent Mikroökonómiai feladatok tára I. címú feladatgyứjteménynek. Különbözik az általában közreadott példatáraktól, hiszen kifejezetten törekedtünk arra, hogy lehetőleg csak olyan feladatokat tartalmazzon, amelyekhez nem elég a tananyag képleteinek ismerete, hanem kicsit komolyabban „el kell gondolkozni rajtuk”. Úgy véljük ugyanis, hogy a tananyag megértéséhez nem elegendő annak egyszerü ismerete, hanem azt alkalmazni is tudni kell. Feladataink ilyen alkalmazások. 